\title{
A RESERVA DE JURISDIÇÃO NO PROCESSO PENAL - DOS REFLEXOS NO INQUÉRITO PARLAMENTAR
}

\begin{abstract}
Dissertação apresentada ao Departamento de Direito Processual da Universidade de São Paulo como exigência parcial para obtenção do grau de Mestre em Direito Processual Penal, sob a orientação do Professor Doutor José Raul Gavião de Almeida
\end{abstract}

Universidade de São Paulo

Faculdade de Direito

São Paulo - 2010 
"Quanto maior o poder, mais perigoso é o

abuso.” E. BURKE, Discurso de 07.02.1771 


\section{AGRADECIMENTOS}

Certa vez um amigo disse que um trabalho acadêmico nunca é finalizado, ele simplesmente é abandonado. Outro, ainda, alertou sobre a necessidade de entregar a dissertação com começo, meio e fim, ainda que não se tenha atingido o nível de excelência almejado, uma vez que o título de Mestre só será obtido se o trabalho estiver completo.

Assim, certa de que o trabalho poderia ser aprimorado em muitos aspectos e de que eu iria alterá-lo enquanto me fosse permitido, abandono esta dissertação com a convicção de que apesar de todos os esforços empreendidos, existem falhas, e estas devem ser atribuídas apenas a mim, considerando o apoio encontrado em todos aqueles que me rodeiam.

Começo, portanto, agradecendo a meu orientador, Professor José Raul Gavião de Almeida, pois sem sua admissão, atenção e conselhos, não teria sequer iniciado esta jornada. Ao Professor Antonio Scarance Fernandes, mestre na mais profunda acepção do termo, com quem tanto aprendi e em cuja dedicação busco inspiração. Ao Professor Mauricio Zanoide de Moraes, responsável pela minha iniciação no Processo Penal, dada a admirável forma de lecionar, agradeço pelo grande estímulo à minha veia acadêmica, seja pelo elogio, seja pela crítica. E ao Professor Gustavo Henrique Righi Ivahy Badaró, pelas preciosas considerações feitas na ocasião do exame de qualificação.

Aos meus pais, Fernando e Rosária, raros exemplos de eternos estudantes, pelo constante incentivo ao meu gosto pelas letras e pela sempre pronta ajuda, ainda que desajeitada, nos momentos de aflição. A minha irmã, Cláudia, cuja admiração impulsioname a sempre dar o meu melhor, pelo temor de desapontá-la e pelo dever de servir de exemplo. Ao amigo-irmão, Victor, pelo favor de revisar este texto. Às minhas avós, Antonia e Lecia, que sempre rezam e torcem pelo meu sucesso.

A todos os amigos, colegas de trabalho e colegas de estudos, cujos nomes não posso transcrever pelo receio de cometer a injustiça de deixar de mencionar algum. Contudo, tenho a certeza de que todos se sentirão incluídos em meu agradecimento ao lerem a descrição de todas as atitudes afetuosas recebidas nesse período. Agradeço-os, assim, pela obtenção dos textos mais inacessíveis; pelo envio das mais recentes decisões dos tribunais sobre o tema estudado; pelo esclarecimento das minhas dúvidas; pelas boas vibrações emanadas; pelos momentos de desabafo; pelas palavras de encorajamento nos 
momentos de desânimo; e pela compreensão diante das inúmeras recusas aos reiterados convites.

Por fim e, principalmente, agradeço à energia cósmica, que alguns chamam de Deus, pela força, serenidade e concentração a mim proporcionadas, as quais me possibilitaram superar todas as intempéries ocorridas nos últimos três anos e atingir o grande desejo de concluir a dissertação de Mestrado. 


\section{RESUMO}

Este estudo tem por escopo explorar o instituto da reserva de jurisdição, analisando suas origens, motivações e consequiências. Outrossim, visa estabelecer os critérios para se eleger as situações que devem ser submetidas a ela quando não houver previsão expressa no ordenamento jurídico, além de aplicá-lo ao âmbito do Processo Penal, avaliando a necessidade de sua aplicação nos meios de prova e nos meios de obtenção de prova.

A reserva de jurisdição consiste no impedimento de outros órgãos exercerem atividades pertencentes ao núcleo essencial da função jurisdicional, sendo corolário do princípio da separação dos poderes, um dos pilares do Estado Democrático de Direito.

Embora se admita uma interpenetração entre as funções estatais, existe uma parcela de cada uma delas que só permite a intervenção do órgão mais adequado e aparelhado para desenvolvê-la. No caso da função jurisdicional, isso ocorre quando o conflito de interesses a ser resolvido de forma definitiva envolve um bem constitucionalmente protegido ou um direito fundamental e só pode ser solucionado pelo Poder Judiciário.

Não obstante, pretende-se aplicar as conclusões extraídas acerca da reserva de jurisdição a uma situação prática que se costuma se apresentar problemática, a investigação perpetrada por meio das Comissões Parlamentares de Inquérito.

O objetivo é dar ao $\$ 3^{\circ}$ do artigo 58 da Constituição Federal, que confere aos membros das CPIs poderes investigatórios próprios de autoridades judiciais, interpretação mais consoante com a tese desenvolvida, ou seja, defender que apenas os magistrados podem autorizar a efetivação de medidas restritivas de direitos fundamentais necessárias no bojo de um inquérito parlamentar, ainda que não haja expressa previsão no ordenamento jurídico.

Palavras-chave: Reserva de jurisdição - função jurisdicional - medidas restritivas de direitos fundamentais - Comissões Parlamentares de Inquérito - poderes investigatórios 


\begin{abstract}
This work aims to explore the scope of the institute "Judicial Reserve", analyzing its origins, motivations and consequences. It also seeks to establish the criteria to choose the situations that should be subjected to it when there is no express provision in the legal system, and apply it to the scope of Criminal Proceeding, evaluating the need of its implementation in the evidence and in the means of obtaining evidence.

"Judicial Reserve" is the prevention of other agencies carry out activities belonging to the core of the judicial function, which is a corollary of the principle of separation of powers, one of the pillars of the Democratic State.

Although it is accepted interpenetration between the state functions, there is a portion of each that only allows the intervention by the most suitable and equipped agency to develop it. In case of the judicial function, this occurs when the conflict of interests to be resolved definitively involves a constitutionally protected good or a fundamental right, and can only be resolved by the Judiciary.

Nevertheless, we intend to apply the conclusions drawn about the "Judicial Reserve" to a practical situation that used to present problems, the investigation conducted by the Parliamentary Committees of Inquiry.

The goal is to give the $\S 3$ of article 58 of the Constitution, which gives members of CPI investigative powers similar to the judicial powers, interpretation more consonant with the thesis developed, ie, defending that only judges can authorize the execution of measures restricting fundamental rights on an parliamentary inquiry, although there is no express provision in the law.
\end{abstract}

Keyword: Judicial Reserve - judicial function - measures restricting fundamental rights Parliamentary Committees of Inquiry - investigative powers 


\section{SUMÁRIO}

1.INTRODUÇÃO 10

2.DA ORGANIZAÇÃO DO ESTADO DEMOCRÁTICO DE DIREITO 13

2.1. CONSIDERAÇÕES INICIAIS SOBRE PODER, ESTADO E DIREITO 14

2.2. HISTÓRICO.

2.3. OS PRESSUPOSTOS DO ESTADO DE DIREITO NA TEORIA DE CANOTILHO 22

2.4. CARACTERIZAÇÃO DO ESTADO DEMOCRÁTICO DE DIREITO NO BRASIL 26

2.4.1. SUBMISSÃO À LEI 30

2.4.2. RESPEITO À DIGNIDADE DA PESSOA HUMANA …........................................ 32

2.4.3. PODERES HARMÔNICOS E INDEPENDENTES ENTRE SI .............................. 35

2.5. DAS FUNÇÕES ESSENCIAIS AO ESTADO E SUA DIVISÃO .................................. 37

2.5.1. DA EVOLUÇÃO DA TEORIA DA SEPARAÇÃO DOS PODERES...................... 37

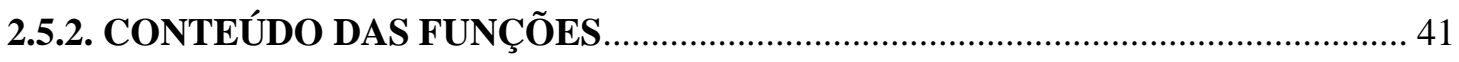

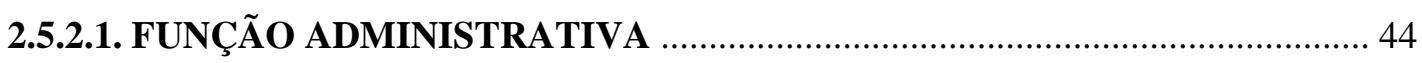

2.5.2.2. FUNÇÃO LEGISLATIVA E DE CONTROLE ESPECÍFICO......................... 46

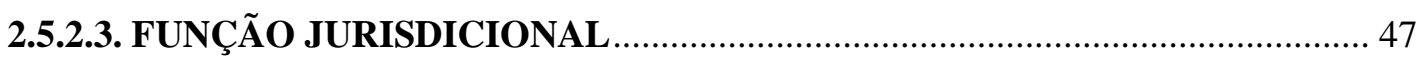

2.5.3. CONJUNTURA ATUAL: INTERPENETRAÇÃO DE PODERES E EXERCÍCIO

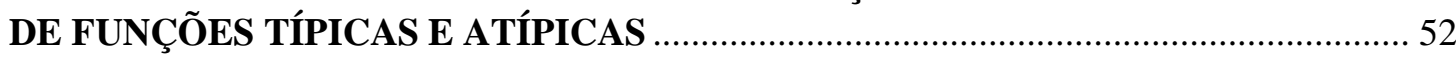

3.RESERVA DE JURISDIÇÃÁO................................................... 58

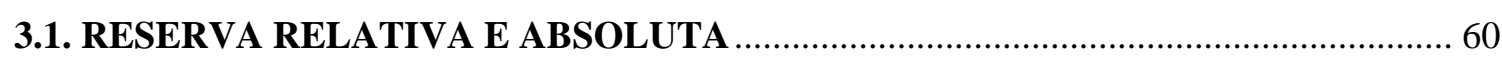

3.1.1. DEFINIÇÃO DO CONTEÚDO DOS NÍVEIS DE RESERVA .......................... 63

3.1.2. HIPÓTESES DE APLICAÇÃO DA RESERVA ABSOLUTA ............................ 65

3.2. FATORES JUSTIFICANTES DA CLÁUSULA DE RESERVA DE JURISDIÇÃO 68

3.2.1. A ESSÊNCIA DA FUNÇÃO JURISDICIONAL E SEUS ATRIBUTOS INDEPENDÊNCIA, IMPARCIALIDADE E ISENÇÃO 68

3.2.1.1. LEGITIMIDADE DO PODER JUDICIÁRIO …............................................ 72

3.2.1.2. INDEPENDÊNCIA OBJETIVA E SUBJETIVA (IMPARCIALIDADE E

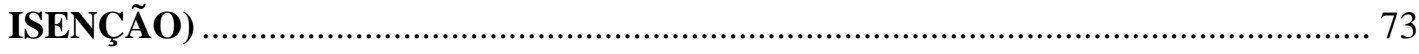

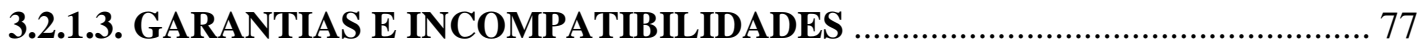

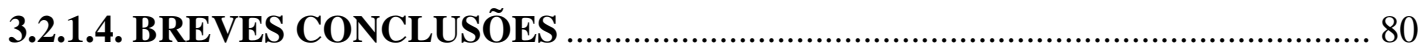


3.2.2. A NATUREZA DOS DIREITOS FUNDAMENTAIS E A INDISPENSABILIDADE DE UMA DECISÃO JUDICIAL PARA SOLUCIONAR OS CONFLITOS ENTRE ELES

3.2.2.1. CONTEÚDO ESSENCIAL DOS DIREITOS FUNDAMENTAIS E O

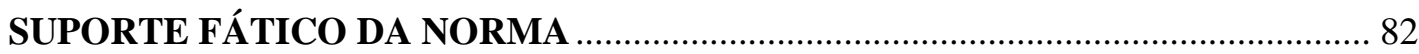

3.2.2.2. CONFLITOS ENTRE NORMAS E SUAS SOLUÇÕES ................................. 88

3.2.2.3. O POSTULADO DA PROPORCIONALIDADE ............................................. 94

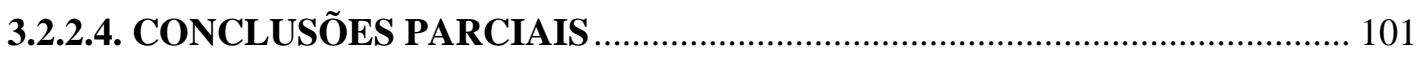

3.2.3. O DEVIDO PROCESSO LEGAL E A IMPERIOSIDADE DA MANIFESTAÇÃO JUDICIAL

3.3. CRITÉRIOS PARA ELEGER OS CASOS DE RESERVA DE JURISDIÇÃO ABSOLUTA IMPLÍCITAS.

4.A RESERVA DE JURISDIÇÃO NO PROCESSO PENAL 111

4.1. PROCESSO PENAL: FINALIDADES E A BUSCA DA VERDADE .................... 111

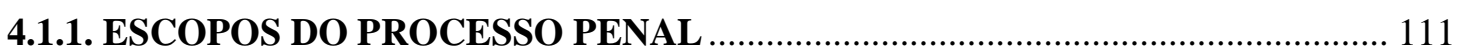

4.1.2. A VERDADE PROCESSUALMENTE POSSÍVEL ................................................ 115

4.2. MEDIDAS RESTRITIVAS DE DIREITOS FUNDAMENTAIS UTILIZADAS NA INSTRUÇÃO PROCESSUAL E SUBMETIDAS À RESERVA DE JURISDIÇÃO.......... 124

4.2.1. CONDUÇÃO COERCITIVA DE TESTEMUNHA …........................................ 129

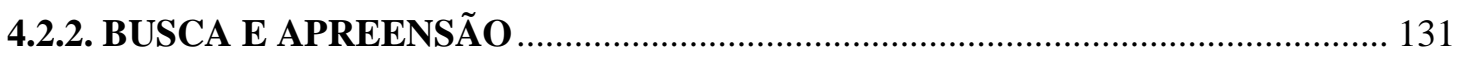

4.2.3. INTERCEPTAÇÃO E GRAVAÇÕES TELEFÔNICAS ….................................. 136

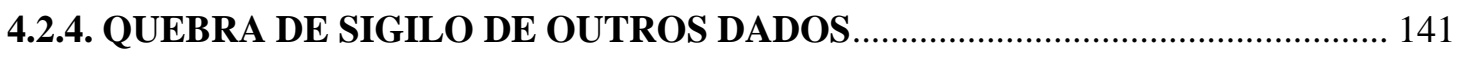

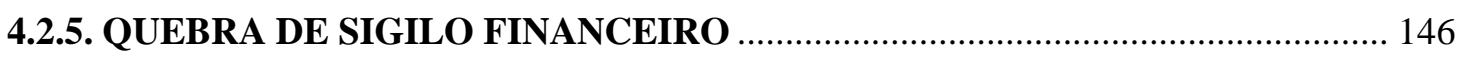

4.2.6. OUTRAS MEDIDAS RESTRITIVAS DE DIREITOS FUNDAMENTAIS......... 153

5.COMISSÕES PARLAMENTARES DE INQUÉRITO.................. 154

5.1. O PODER LEGISLATIVO E A FUNÇÃO DE CONTROLE .................................. 154

5.2. COMISSÕES PARLAMENTARES DE INQUÉRITO - CONCEITO E ESSÊNCIA 156

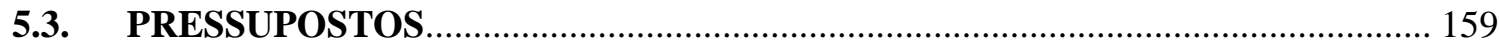

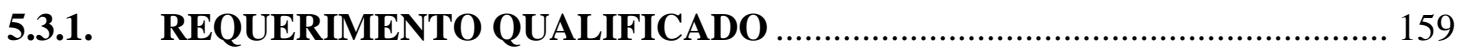

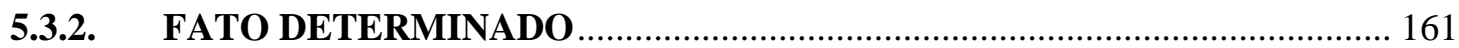

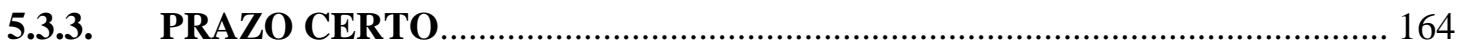

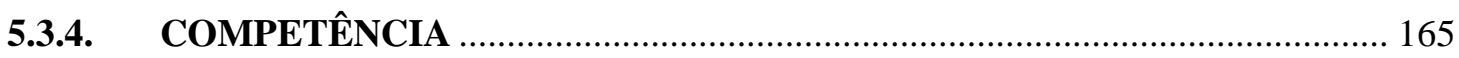

5.3.5. CORRELAÇÃO ENTRE OBJETO E INVESTIGAÇÃO ................................ 166

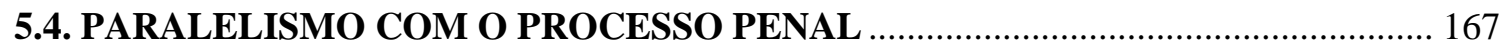

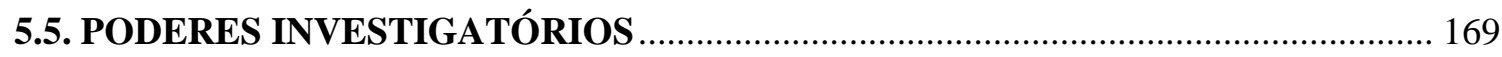


5.6. LIMITES DA ATUAÇÃO.

5.7. POSSÍVEIS RESULTADOS.

6.REFLEXOS DA RESERVA DE JURISDIÇÃO NO INQUÉRITO PARLAMENTAR 177

6.1. A INVESTIGAÇÃO REALIZADA NO ÂMBITO DO INQUÉRITO PARLAMENTAR

6.1.1. INVESTIGAÇÕES PRELIMINARES

6.1.2. A NATUREZA DOS ATOS PRATICADOS NA INVESTIGAÇÃO

PRELIMINAR

6.1.3. ATOS PRATICADOS NO ÂMBITO DO INQUÉRITO PARLAMENTAR . 188

6.2. COMPARAÇÃO DOS ATRIBUTOS ESSENCIAIS AOS EXECUTORES DA FUNÇÃO JURISDICIONAL COM AS CARACTERÍSTICAS DOS PARLAMENTARES 190

6.3. SIGNIFICADO DA EXPRESSÃO "PODERES DE INVESTIGAÇÃO PRÓPRIOS DE AUTORIDADES JUDICIAIS"

6.4. APLICAÇÃO DA CLÁUSULA DE RESERVA DE JURISDIÇÃO NO INQUÉRITO PARLAMENTAR

6.5. ATOS QUE PODEM SER PRATICADOS PELAS COMISSÕES

PARLAMENTARES DE INQUÉRITO

6.6. O DESRESPEITO À CLÁUSULA DE RESERVA DE JURISDIÇÃO NO

INQUÉRITO PARLAMENTAR - CONSEQÜÊNCIAS E REMÉDIOS.

7.CONCLUSÃO 218

8.BIBLIOGRAFIA 224

8.1. INTERNET. 238 


\section{INTRODUÇÃO}

A reserva de jurisdição impõe-se a situações em que a função do Poder Judiciário não pode ser exercida por qualquer outro poder, porquanto existe a necessidade de se solucionar, de forma definitiva, conflitos de interesses que resultam em restrições a bens constitucionalmente protegidos. A intervenção do Poder Judiciário seria indispensável nesses casos, por ser o único poder imparcial e legitimado para autorizar limitações a direitos e garantias constitucionais.

O instituto é conhecido, mas ainda pouco estudado, de modo que sua utilização acaba se restringindo às previsões expressas no ordenamento, ignorando-se seu sentido material, suas origens, sua razão de ser, isto é, a possibilidade e a necessidade de se estender a exigência de decisão judicial prévia a casos não positivados. O próprio Supremo Tribunal Federal vem postergando manifestação decisiva sobre o tema.

No Processo Penal sua definição é de enorme importância, tendo em vista que nas fases de investigação preliminar e de instrução criminal é freqüente a necessidade de se perpetrar medidas que afetam direitos fundamentais para a obtenção de elementos de prova. Exemplo são as interceptações telefônicas, a quebra de sigilo de dados e a realização de exames atentatórios à integridade física da pessoa, como o teste de DNA.

Por outro lado, as Comissões Parlamentares de Inquérito são uma realidade inafastável do cenário político brasileiro. É raro o dia em que se abre o jornal sem a notícia de uma investigação levada a cabo no âmbito do Parlamento, seja ele municipal, estadual ou federal. Além disso, os escândalos de corrupção e a exploração midiática desses casos exigem uma resposta imediata ao clamor público por justiça.

Nessa conjuntura, o inquérito parlamentar emerge como instrumento para implementação da fiscalização e controle do Poder Executivo, tarefa atribuída expressamente ao Poder Legislativo por determinação constitucional. Para tanto, é dado máximo significado à idéia de eficiência, deixando-se de lado, muitas vezes, a legalidade. No afã de obter o maior número de informações possíveis para subsidiar suas atividades, 
os parlamentares efetivam medidas que abalam direitos fundamentais dos envolvidos, crentes de estarem autorizados pelo disposto no artigo $58, \S 3^{\circ}$ da Constituição Federal.

Com efeito, referido preceito constitucional confere às Comissões Parlamentares de Inquérito poderes investigatórios próprios de autoridades judiciais. Muitos enxergam neste enunciado a possibilidade de atuar da mesma maneira que um magistrado atua na fase de instrução processual, deferindo a realização de todo e qualquer tipo de meio de obtenção de prova ou meio de prova. Ocorre que não é a melhor interpretação. Em se tratando de conceito jurídico indeterminado, há que se empreender esforço para delimitar seu exato conteúdo.

Temos, portanto, dois obstáculos a superar. O primeiro, considerado central neste trabalho, é a conceituação do instituto da reserva de jurisdição, bem como a definição dos critérios para sua aplicação, tanto de forma genérica, como no plano específico do Processo Penal. Para tanto, será necessário entender a divisão de poderes existente no Estado Democrático de Direito brasileiro e, sobretudo, definir o conteúdo exato da função materialmente jurisdicional, a qual não poderá ser compartilhada com nenhum outro poder estatal.

Delineados os contornos da reserva de jurisdição e estabelecidos os critérios para eleger os casos que a ela devem ser submetidos, é importante analisar a busca da verdade no Processo Penal, bem como os limites a ela impostos pelos direitos fundamentais dos indivíduos, de modo a aplicar as conclusões acerca do tema central do trabalho aos meios de obtenção de prova e aos meios de prova, os quais também são utilizados no bojo do inquérito parlamentar.

Ultrapassada esta fase, convém tratar do segundo obstáculo, definir a extensão dos poderes conferidos às Comissões Parlamentares de Inquérito. Trata-se da aplicação, em uma situação prática que comumente se apresenta como problemática, da teoria sobre a reserva de jurisdição que será desenvolvida.

Uma prévia análise sobre as características do inquérito parlamentar é indispensável para que seja ultimada esta tarefa, mas será dado especial enfoque à definição de atos investigatórios, bem como à comparação das características dos membros dos Poderes 
Judiciário e Legislativo, para que, ao final, sejam definidos os atos que podem ser perpetrados no âmbito de uma investigação parlamentar e aqueles que dependem de prévia autorização judicial, por fazerem parte do núcleo essencial da função jurisdicional. 


\section{DA ORGANIZAÇÃO DO ESTADO DEMOCRÁTICO DE DIREITO}

Se a reserva de jurisdição envolve situações em que apenas um dos poderes estatais pode se manifestar sobre determinados assuntos, é indispensável analisar a estrutura desse Estado para que entendamos o papel que cada um de seus órgãos essenciais desempenha, chegando, portanto, à definição do conteúdo exato da função jurisdicional.

Somente trilhando este caminho podemos entender o que é um ato materialmente jurisdicional, de maneira a conseguir definir as hipóteses em que apenas o Poder Judiciário poderá efetuar a intervenção num caso concreto. Encontraremos, assim, o que denominaremos de núcleo essencial da função jurisdicional, área que não admitirá a intervenção de qualquer outro órgão.

Outrossim, também é objeto deste estudo estabelecer limites para atuação das Comissões Parlamentares de Inquérito no que tange à investigação pode elas desenvolvida. Para tanto, é fulcral lembrar que são comissões pertencentes ao Poder Legislativo, entender as funções deste órgão e definir, por fim, até que ponto pode se imiscuir em atividades que, a priori, são atribuídas ao Poder Judiciário.

Desta feita, o entendimento acerca da composição de um Estado Democrático de Direito mostra-se como ponto de partida para nossos escopos. Passamos, portanto, à abordagem das noções iniciais de poder, Estado e Direito, para, depois de apresentar um breve histórico sobre o desenvolvimento do Estado de Direito, enumerar seus pilares essenciais e tratar de forma mais detalhada um deles, ponto central da primeira parte deste estudo, a separação dos poderes ou divisão de funções. Neste último tópico é que estudaremos as atribuições de cada órgão componente do Estado, dando especial atenção à função jurisdicional, vedete de nosso trabalho.

Todo este esforço remete não apenas à intenção de demonstrar a origem dos institutos estudados, mas também e, principalmente, para dizer que, ao se afrontar a 
cláusula de reserva de jurisdição, seja explícita ou implícita, estar-se-á afrontando, em última instância, a própria essência do Estado Democrático de Direito, o que é inadmissível numa sociedade que se diga defensora da liberdade e protetora da dignidade da pessoa humana.

\subsection{CONSIDERAÇÕES INICIAIS SOBRE PODER, ESTADO E DIREITO}

O poder é necessário em qualquer dimensão de atividade humana e existiu desde as sociedades mais primitivas, exercendo uma função de coordenação e coesão. $\mathrm{Na}$ sua acepção ligada ao conceito de Estado, apareceu já na Grécia antiga, mediante as palavras kratos (poder) e arché (força) e permeia todas as designações das formas de Estado como democracia ou aristocracia. ${ }^{1}$

Orlando Viegas Martins Afonso preleciona que o poder do Estado, por um lado, traduz-se como um controle sobre as situações sociais e, por outro, como uma supremacia sobre as pessoas, revelada pela capacidade de impor seus interesses a elas. ${ }^{2}$ Tal pode se concretizar de diferentes formas, o que ensejará as diversas qualificações do poder.

Noberto Bobbio nos ensina que direito e poder são duas faces da mesma moeda. Ao mesmo tempo em que só o poder tem o condão de criar o direito, sendo essencial à sua positivação, só o direito é capaz de limitar o poder. ${ }^{3}$ Em decorrência dessa reciprocidade, temos que o Estado, como expressão do poder, tem uma permanente relação com o direito. ${ }^{4}$

\footnotetext{
${ }^{1}$ BAstos, Celso Ribeiro, Curso de Teoria do Estado e Ciência Política, $4{ }^{\mathrm{a}}$ Ed. São Paulo, Editora Saraiva, 1999, p. 76; AfOnso, Orlando Viegas Martins, Poder Judicial - Independência in dependência, Coimbra, Livraria Almedina, 2004, p. 11.

${ }^{2}$ Afonso, Orlando Viegas Martins, Poder Judicial..., p. 11. Nesse sentido é a definição de poder dada por Weber, segundo o qual poder é a probabilidade de impor a própria vontade dentro de uma relação social, mesmo contra toda a resistência e qualquer que seja o fundamento desta probabilidade. Ver DuTRA, Delamar José Volpato, A legalidade como forma do Estado de Direito, in Kriterion, n. ${ }^{\circ}$ 109, Belo Horizonte, Jun/2004, p. 61, obtido em www.scielo.br, acesso em 17.11.2008.

${ }^{3}$ Bobвio, Noberto, O futuro da democracia, Marco Aurélio Nogueira (trad.), 10a ed., São Paulo, Paz e Terra, 2000 , p. 23.

${ }^{4}$ A definição sociológica de Estado preconizada por Weber revela adequadamente o fato do Estado ser uma expressão do poder. Para ele, o Estado é um instituto político que mantém a ordem através do monopólio da
} 
A relação supra mencionada também é constatada por Dalmo Dallari, segundo o qual qualquer sociedade humana revela a presença de uma ordem jurídica e de um poder. $\mathrm{Na}$ verdade, o autor defende que o conceito de poder estatal está contido no conceito de ordem jurídica, a ponto de conceituar o Estado como "a ordem jurídica soberana que tem por fim o bem comum de um povo situado em determinado território". 5

Nos termos desse conceito, todo poder possui qualificação jurídica. Apesar disso, é impossível afastar totalmente o viés político da sua configuração. Por tal razão, a idéia de graus de juridicidade é usada para explicar a alternância dos fatores jurídico e político na qualificação do poder:

“...quando se diz que o poder é jurídico isso está relacionado a uma graduação de juridicidade, que vai de um mínimo, representado pela força ordenadamente exercida como um meio para atingir certos fins, até a um máximo, que é a força empregada exclusivamente como um meio de realização do direito e segundo as normas jurídicas. ",

Da mesma forma, Dalmo Dallari apresenta duas vertentes acerca da definição de Estado, a política, que se liga à idéia de força, e a jurídica, que dá primazia ao componente jurídico, destacando o elemento da ordem. ${ }^{7}$ Assim, sendo o Estado uma expressão de poder, como dito por Bobbio, podemos traçar um paralelo entre as duas noções e concluir que, atualmente, busca-se o máximo de juridicidade em ambas, mas sempre são encontradas notas políticas nelas.

No mesmo sentido, Celso Ribeiro Bastos assevera que o Estado de Direito preconizado pelos modernos estudiosos, deve significar a subordinação do poder a normas

força física, porquanto pode contar com a coerção externa (o poder). Ver DUTRA, Delamar José Volpato, $A$ legalidade como forma do Estado de Direito..., p. 61.

5 Dallari, Dalmo de Abreu, Elementos de Teoria Geral do Estado, 22 ${ }^{\mathrm{a}}$ Ed., São Paulo, Editora Saraiva, 2001, p. 111 e 118. Para o autor, a noção de Estado deve dar maior ênfase ao fator jurídico, sem, contanto, ignorar os fatores não jurídicos.

${ }^{6}$ Dallari, Dalmo de Abreu, Elementos de Teoria Geral do Estado..., p. 113-114.

${ }^{7}$ DAllari, Dalmo de Abreu, Elementos de Teoria Geral do Estado..., p. 116-117. 
jurídicas cuja positividade foi por ele declarada. Todavia, o poder nunca é puramente jurídico, de modo que mesmo no grau máximo de juridicidade, haverá um viés político. ${ }^{8}$

Como se pode perceber, conquanto se reconheça a relação intrínseca entre direito e poder, a idéia de Kelsen, segundo o qual o Estado é uma ordem jurídica isenta de elementos políticos ${ }^{9}$ é afastada pela maior parte dos autores, que temem o desvirtuamento do Estado Legal preconizado pelo estudioso austríaco, pois, conforme Delamar José Volpato Dutra, o autor confundiu os conceitos de Estado Legal e Estado de Direito, deixando de se perguntar acerca da questão de legitimidade ou justiça, o que possibilita justificar qualquer conteúdo. ${ }^{10}$ Com efeito, em diversos momentos históricos, a legalidade formal foi utilizada para dar vestes legítimas a ditaduras, do que se pode citar o nazismo e o fascismo como exemplos. ${ }^{11}$

Assim, o que diferenciará um Estado legítimo de uma ditadura serão os detentores do poder. Como se sabe, um governo é classificado como autocrático quando o poder é exercido por apenas uma pessoa e denota a personalização do poder, havendo uma dominação de cima para baixo. Já a democracia é verificada nos governos em que o poder é conferido e exercido pelo povo como um todo, de baixo para cima, sendo conceito muito mais abrangente que o de mero Estado legal kelseniano ${ }^{12}$. O verdadeiro Estado de Direito

\footnotetext{
${ }^{8}$ Bastos, Celso Ribeiro, Curso de Teoria do Estado e Ciência Política, $4^{\mathrm{a}}$ Ed., São Paulo, Editora Saraiva, 1999, p. 79.

${ }^{9}$ KeLSEN, Hans, Teoria Pura do Direito..., p. 317. Delamar José Volpato Dutra afirma que tanto para Weber quanto para Kelsen, o Direito é visto como uma ordem de coerção, ou organização da força. Ocorre que para Kelsen validade da norma depende apenas de sua existência. Para ele, o direito regula sua criação. É o Direito que regula a conduta dos indivíduos que praticarão os atos de Estado que criarão o Direito. Ora, diante disso, falar em Estado de Direito seria tautológico, um pleonasmo, já que todo Estado, como ordem jurídica, é Estado de direito. Cf, A legalidade como forma do Estado de Direito..., p. 62-63.

${ }^{10}$ DuTRA, Delamar José Volpato, A legalidade como forma do Estado de Direito..., p. 63.

11 Dallari, Dalmo de Abreu, Estado de Direito e Cidadania, in Direito Constitucional - Estudos em Homenagem a Paulo Bonavides, Eros Roberto Grau e Willis Santiago Guerra Filho (org.), São Paulo, Malheiros Editores, 2001, p. 196; Verdú, Pablo Lucas, A luta pelo Estado de Direito, Agassiz Almeida Filho (trad. e pref.), Rio de Janeiro, Forense, 2007, p. 7; SilvA, José Afonso da, O Estado Democrático de Direito, in Direito Constitucional Brasileiro - perspectivas e controvérsias contemporâneas, Regina Quaresma e Maria Lúcia de Paula Oliveira (coord.), Rio de Janeiro, Editora Forense, 2006, p. 11.

${ }^{12}$ Silva, José Afonso da, O Estado Democrático de Direito..., p.7. Noberto Bobbio afirma que por regime democrático entende-se o conjunto de regras para a formação de decisões coletivas em que está prevista e facilitada a participação mais ampla possível dos interessados. Ver BoBBIO, Noberto, $O$ futuro da democracia..., p. 22; SILVA, José Afonso da, Curso de direito constitucional positivo, $22^{\mathrm{a}}$ ed. rev. e atual., São Paulo, Malheiros Editores, 2003, p. 124.
} 
deve ser entendido a partir da democracia, pois é a partir desta que se revela a legitimidade do Direito. $^{13}$

Nessa esteira, segundo Bobbio, quando o poder pertence a apenas um indivíduo ou a um seleto grupo deles, temos um Estado despótico, que é o ideal do ponto de vista do poder. Por outro lado, quando o poder pertence ao povo e é exercido pelo maior número de pessoas possível, temos um Estado Democrático, ideal do ponto de vista do Direito. ${ }^{14}$

Ora, é indubitável que a evolução histórica da humanidade nos defronta com as mais diversas formas de governo e de exercício de poder, evolução esta que merece análise para que possamos compreender o sentido do Estado Democrático de Direito preconizado como a forma ideal de exercício do poder de acordo com as normas jurídicas. Sendo assim, passamos à descrição da história do desenvolvimento do Estado de Direito, desde sua forma mais simples e liberal, equivalente ao Estado Legal, passando pelo Estado Social, até chegar no atual Estado Democrático de Direito, em que encontramos a configuração da separação dos poderes e donde brota o instituto aqui estudado da reserva de jurisdição.

Sabemos da importância do estudo das razões do surgimento de um instituto para seu perfeito entendimento. Portanto, passamos a um breve esboço histórico do nascimento do Estado Democrático de Direito na história da humanidade.

\subsection{HISTÓRICO}

A aparição do Estado de Direito está ligada a uma determinada fase histórica da evolução do estado absoluto ao liberal. Com efeito, os monarcas absolutistas que governavam o mundo até o século XVII, criavam e impunham as normas de forma livre, de maneira que o poder era exercido ilimitadamente. A partir do momento em que se passou a exigir o ajuste do exercício do poder a prescrições legais formuladas por um

\footnotetext{
${ }^{13}$ DuTRA, Delamar José Volpato, A legalidade como forma do Estado de Direito..., p. 59.

${ }^{14}$ BoвBIO, Noberto, O futuro da democracia..., p. 23.
} 
parlamento, iniciou-se um processo que culmina com o surgimento do Estado Democrático de Direito. $^{15}$

Inocêncio Mártires Coelho tem interessante passagem sobre o surgimento do Estado de Direito, a qual vale transcrever:

"Precisamente por isso é que, no plano histórico, sem discrepâncias, juristas, filósofos e cientistas políticos assinalam o surgimento do Estado de Direito no momento em que se consegue pôr freios à atividade estatal por meio da lei, vale dizer, no instante em que o próprio Estado se submete a leis por ele criadas, ainda que isso possa parecer um paradoxo, e tão embaraçoso paradoxo, que já houve quem estabelecesse comparação entre a idéia do Estado de Direito e o mistério teológico do Deus-Homem, o mistério do criador da Natureza submetido a essa mesma Natureza.",16

À época da Revolução Francesa, o desenvolvimento do capitalismo, bem como as exigências do mercado ensejaram a alteração dos padrões de governo absolutista, impondo a regulamentação do poder e do Estado pelo Direito. A limitação do poder real era vista como um desenvolvimento dos direitos inatos do indivíduo, defendidos por teóricos como Locke e Montesquieu, cujo meio de garantia seria a aplicação da regra técnica da separação de poderes. Corolário dessa tendência, o artigo 16 da Declaração Universal de Direitos do Homem de 1789 consignou que só possuía Constituição o Estado que assegurasse a garantia de direitos e estabelecesse a separação de poderes. ${ }^{17}$

A classe burguesa consolidou os valores do liberalismo dando particular ênfase à liberdade e proteção do indivíduo. Nesse primeiro momento, surge o chamado Estado de

\footnotetext{
15 Verdú, Pablo Lucas, A luta pelo Estado de Direito..., p. 1-5; CoElHO, Inocêncio Mártires, O Perfil Constitucional do Estado Contemporâneo: o Estado Democrático de Direito, in Revista de Informação Legislativa, ano 30, n. ${ }^{\circ} 118$, abrilljunho 1993, Brasília, p. 6.

${ }^{16}$ COELHO, Inocêncio Mártires, O Perfil Constitucional do Estado Contemporâneo..., p. 6.

17 Verdú, Pablo Lucas, A luta pelo Estado de Direito..., p. 4; COELHO, Inocêncio Mártires, O Perfil Constitucional do Estado Contemporâneo...., p. 10.
} 
Direito Liberal, classificado como meramente formal, pois o individualismo era o valor preponderante. ${ }^{18}$ Esta forma de Estado de Direito apresentava como características básicas a primazia da lei e do sistema hierárquico de normas, a observância da legalidade por parte da administração, a divisão dos poderes estatais e o reconhecimento e garantia dos direitos individuais, classificados como direitos fundamentais de primeira geração. ${ }^{19}$

Essas exigências continuaram a existir nos modelos posteriores, embora o modelo proposto tenha esgotado suas possibilidades em virtude de ser unilateral. A igualdade por ele pregada era meramente formal, fundada na generalidade das leis. A garantia das liberdades propiciou o desenvolvimento capitalista, o que gerou novas tensões e lutas sociais. Nessa conjuntura, houve a necessidade desse Estado formal de Direito se transformar em Estado material de Direito com o escopo de realizar a justiça social, preenchendo-se de conteúdos éticos, culturais e sociológicos. Essa evolução coincidiu com o surgimento da segunda geração dos direitos fundamentais, os chamados direitos econômicos e sociais implementados pelas Constituições Russa de 1917 e de Weimar de $1919 .^{20}$

Surge, assim, o Estado Social de Direito, cujo escopo é converter em direito positivo, aspirações sociais, conferindo-lhes garantias jurídicas claras e seguras. Para José Afonso da Silva, a palavra social pode ser interpretada de várias maneiras, de modo que este modelo de Estado serve tanto para a democracia quanto para o totalitarismo. Diante

\footnotetext{
${ }^{18}$ Verdú, Pablo Lucas, A luta pelo Estado de Direito, Agassiz Almeida Filho (trad. e pref.), Rio de Janeiro, Forense, 2007, p. 6; CoELHO, Inocêncio Mártires, O Perfil Constitucional do Estado Contemporâneo..., p. 7. Pablo Verdú esclarece que as bases ideológicas do Estado Liberal se fundamentam em pressupostos jusnaturalistas, que possuem caráter individualista por estarem assentados no homem, titular desses direitos anteriores à sociedade. A medida em que o Estado evolui, esses direitos passam a ser vistos como concessão dele, e se fundamentam na própria lei positiva. p. 79-80.

${ }^{19}$ Silva, José Afonso da, O Estado Democrático de Direito..., p.8; Verdú, Pablo Lucas, A luta pelo Estado de Direito..., p. 13.

${ }^{20}$ Silva, José Afonso da, $O$ Estado Democrático de Direito..., p. 7, 11 e 15; CoElHo, Inocêncio Mártires, $O$ Perfil Constitucional do Estado Contemporâneo..., p. 10-11; Verdú, Pablo Lucas, A luta pelo Estado de Direito..., p. 77-78; CORTEZ, Luís Francisco Aguilar, Judiciário e Democracia: organização e funcionamento do Judiciário na Constituição Federal de 1988, Tese de Doutorado apresentada à Faculdade de Direito da Universidade de São Paulo, 2004, p. 161-162. Pablo Verdú afirma que a Constituição Alemã não economiza no uso de expressões ricas em aspectos éticos, tais como dignidade humana, direitos sagrados e invioláveis, respeito à moral, à família e ao casamento, ver p. 78 .
} 
desta observação e da necessidade de se extirpar o sentido burguês da expressão "Estado de Direito", o autor propõe que a palavra social seja acoplada após a mesma. ${ }^{21}$

Inocêncio Mártires Coelho observa que este modelo foi insuficiente, tendo em vista que não conseguiu realizar a democratização econômica e social, não se concretizando a participação política do povo. Como se sabe, em muitos locais, a tentativa de aplicação do Estado Social de Direito ensejou o surgimento de regimes totalitários, como o fascista e o nazista. $^{22}$

Para combater essa realidade, foram promulgadas as declarações de direito póssegunda guerra mundial, tentando instaurar um novo constitucionalismo, o que só se solidificou na década de 80 , tendo em vista que a divisão do mundo em blocos retardou a disseminação da democracia. ${ }^{23}$

Nessa conjuntura, revelou-se a necessidade de se integrar os valores da liberdade, preconizado pelo Estado Liberal, e igualdade, grande escopo do Estado Social, o que se buscou atingir por meio do Estado Democrático de Direito. ${ }^{24}$ É por isso que José Afonso da Silva preleciona que este terceiro modelo de Estado é um novo conceito que incorpora os princípios dos dois modelos anteriores, superando-os, uma vez que agrega um componente revolucionário de transformação do status quo. O Estado Democrático de Direito emana, portanto, como uma fórmula na qual convergem as concepções atuais do socialismo e da democracia, sem deixar de lado, por óbvio, as liberdades fundamentais. ${ }^{25}$

Assim, resta patente que o Estado Democrático de Direito representa uma evolução do próprio Estado Liberal, não podendo ser rotulado como algo a ele contraposto. De acordo com Noberto Bobbio, o Estado Liberal é pressuposto jurídico do Democrático. Além disso, o autor defende que o poder democrático é indispensável para garantir a

\footnotetext{
${ }^{21}$ Silve, José Afonso da, O Estado Democrático de Direito..., p.12-13; Verdú, Pablo Lucas, A luta pelo Estado de Direito..., p. 79.

${ }^{22}$ CoElHO, Inocêncio Mártires, O Perfil Constitucional do Estado Contemporâneo..., p. 11-17; SILVA, José Afonso da, O Estado Democrático de Direito..., p. 15.

${ }^{23}$ CoRTEZ, Luís Francisco Aguilar, Judiciário e Democracia..., p. 162-163. Foi o que ocorreu no Brasil, onde a democratização foi deflagrada apenas na década de 80, com a campanha diretas já e culminou na promulgação da Constituição Cidadã em 1988.

${ }^{24}$ COELHO, Inocêncio Mártires, O Perfil Constitucional do Estado Contemporâneo..., p. 12-14.

${ }^{25}$ Silva, José Afonso da, O Estado Democrático de Direito..., p. 8 e 16.
} 
existência e garantia das liberdades fundamentais, havendo, portanto, uma relação de retroalimentação entre liberdade e democracia. ${ }^{26}$

Bobbio construiu uma definição mínima de democracia, segundo a qual:

“...por regime democrático entende-se primariamente um conjunto de regras de procedimento para a formação de decisões coletivas, em que está prevista e facilitada a participação mais ampla possível dos interessados. "27

Fica claro que num regime delineado desta maneira, um número muito elevado de membros tem aptidão para a tomada de decisões. Ademais, não se deve menosprezar o compromisso entre as partes de realizar o livre debate para a formação da maioria, tendo em vista que a regra da maioria é a fundamental na democracia. ${ }^{28}$ Para tanto, é indispensável que os cidadãos possuam liberdade de pensamento e de expressão. Ao mesmo tempo, o fato das decisões serem tomadas pelo povo assegura que seus direitos fundamentais não serão violados, o que comprova a tese de retro-alimentação.

Logo, a democracia permite que o Direito segundo o qual o Estado será constituído seja manifestado livre e originariamente pelo povo. É o que lhe confere legitimidade, nos termos da teoria de Habermas, não bastando a mera observância da legalidade, embora esta também seja indispensável. Neste Estado, o poder pertence ao povo, mas como não pode

\footnotetext{
${ }^{26}$ BobBIO, Noberto, O futuro da democracia..., p. 32-33.

${ }^{27}$ Idem, p. 22.

${ }^{28}$ Idem, p. 31. Embora não se possa deixar de lado a importância da regra da maioria, deve-se consignar as críticas tecidas por Fábio Konder Comparato, baseado em Rousseau. Para ele, a vontade que deve ser levada em consideração não é a da maioria, mas a geral. Elas diferem porque esta não pode ser obtida pelo mero cômputo numérico, mas sim pela homogeneidade de conteúdo ou objeto das diversas manifestações de vontade. Nas palavras do autor: "A expressão da soberania popular não fica, assim, confinada ao número dos votantes, mas à qualidade dos votos. No rigor lógico desse raciocínio, a opinião da minoria, ou mesmo de um só, deveria ser tomada como expressão da 'vontade geral' e, portanto, da soberania, se todos os demais votantes defendessem, com seus votos, interesses particulares e não o interesse geral." Cf. Comparato, Fábio Konder, Para Viver a Democracia, São Paulo, Brasiliense, 1989.
} 
ser exercido por todos concomitantemente, será conquistado mediante legítimos e normais processos democráticos. ${ }^{29}$

Neste ponto, é interessante observar uma questão terminológica. A Constituição portuguesa traz a expressão Estado de Direito Democrático. Conquanto não se possa taxála de equivocada, a expressão Estado Democrático de Direito, adotada pela Constituição brasileira, é muito mais adequada, pois o ideal é que o adjetivo democrático qualifique diretamente o Estado, de sorte a irradiar valores da democracia sobre todos os seus elementos constitutivos, sobretudo a ordem jurídica, conforme exposto no parágrafo anterior. $^{30}$

E por falar em Constituição Portuguesa, não poderiam ser olvidados os apontamentos de J.J. Gomes Canotilho sobre pressupostos do Estado de Direito, pois, além do brilhantismo de sua teoria, ela serve perfeitamente à justificação da defesa da reserva de jurisdição, haja vista o autor ser um dos precursores do tema objeto deste estudo.

\subsection{OS PRESSUPOSTOS DO ESTADO DE DIREITO NA TEORIA DE} CANOTILHO

Optou-se por abrir um item específico para apresentar a visão de Canotilho sobre o Estado de Direito por esta ser bastante peculiar. Os autores que tratam do tema não costumam mencionar sua sistematização, mas, em última instância, aproxima-se do defendido pelos demais doutrinadores, apresentando, por óbvio, uma admirável evolução.

Canotilho enumera os pressupostos do Estado de Direito, englobando os materiais e os formais. Com efeito, pressuposto, em sua acepção jurídica, é definido

${ }^{29}$ ReAle, Miguel, O Estado Democrático de Direito e o Conflito das Ideologias, $2^{\mathrm{a}}$ ed. rev., São Paulo, Saraiva, 1999, p. 2 e 9; DutRA, Delamar José Volpato, A legalidade como forma do Estado de Direito..., p. 59.

${ }^{30}$ Silva, José Afonso da, O Estado Democrático de Direito..., p.15; DALlari, Dalmo de Abreu, Estado de Direito e Cidadania..., p. 196-197. 
como "circunstância ou fato em que se considera um antecedente necessário de outro" Sendo assim, o ilustre doutrinador português elenca circunstâncias que devem ser implementadas para que possa surgir um ambiente propício ao desenvolvimento do Estado de Direito. São pressupostos materiais a juridicidade, a constitucionalidade e os direitos fundamentais; e são formais a divisão de poderes e a administração local autônoma.

A juridicidade relaciona-se à idéia de ordenação através do direito, ponto que já foi abordado em tópico anterior. No mesmo sentido do exposto, a lei formal não é suficiente, apontando-se para a idéia de Justiça, exigindo-se proteção aos direitos e equidade na distribuição de direitos e deveres fundamentais. ${ }^{32}$ Diz o autor:

"A justiça fará, assim, parte da própria idéia de direito (Radbruch) e esta concretizar-se-á através de princípios jurídicos materiais cujo denominador comum se reconduz à afirmação e respeito da dignidade da pessoa humana, à protecção da liberdade e desenvolvimento da personalidade e à realização da igualdade. "33

A constitucionalidade pressupõe a existência de uma constituição normativa estruturante de uma ordem jurídico-normativa fundamental vinculativa de todos os poderes públicos. Seu principal dote é a supremacia da constituição, expressão do primado do Direito essencial ao Estado de Direito. Possui importantes implicações, as quais passamos a abordar. $^{34}$

Deriva da constitucionalidade a necessidade do legislador se vincular à constituição, de maneira a elaborar as leis em conformidade com o que nela está prescrito, isto é, pelo órgão nela determinado, seguindo o procedimento nela firmado e dando-lhe a forma necessária. Outrossim, o conteúdo da constituição é o parâmetro material dos atos

${ }^{31}$ Dicionário Houaiss, disponível em http://houaiss.uol.com.br, acesso em 06.12.2008.

${ }^{32}$ Canotilno, José Joaquim Gomes, Direito constitucional e teoria da constituição, $7^{\mathrm{a}}$ ed., Coimbra, Almedina, 2003, p. 243-245.

${ }^{33}$ Idem, p. 245.

${ }^{34}$ Idem, p. 245. 
legislativos, que não podem contrariá-la. Também devem possuir conformidade com a constituição todos os atos dos poderes públicos. Tudo isso tem a ver com a força normativa da constituição, que, apesar de não ter o condão de realizar uma regulação completa de todos os atos, não poderá ser ignorada quando o fizer. ${ }^{35}$

Ainda, a supremacia da constituição exprime-se através da reserva de constituição, segundo a qual determinadas questões não devem ser objeto de leis ordinárias. Sua concretização dá-se, basicamente, por meio de dois princípios: o princípio da tipicidade constitucional de competências e o princípio da constitucionalidade de restrições a direitos, liberdades e garantias. ${ }^{36}$

O terceiro e último pressuposto material do Estado de Direito é o sistema de direitos fundamentais. Trata-se da necessidade de haver uma base antropológica que o estruture, o que pode vir consignado por meio do respeito e garantia de efetivação dos direitos fundamentais, ou pelo embasamento na dignidade da pessoa humana. ${ }^{37}$

Estes três pressupostos já apontados relacionam-se à idéia de ordenação subjetiva, a qual confere aos indivíduos um status jurídico ancorado nos direitos fundamentais. Porém, a seu lado, situa-se a ordenação objetiva que, conquanto não deixe de se relacionar com a constitucionalidade, tem como princípio estruturante o quarto pressuposto do Estado de Direito, a divisão de poderes. ${ }^{38}$

$\mathrm{Na}$ verdade, Canotilho enxerga o princípio da divisão de poderes como uma das dimensões do princípio da separação de poderes que, por sua vez, possui uma dimensão negativa e uma positiva. A divisão de poderes é a dimensão negativa, a qual implica a divisão, controle e limite do poder. Por sua vez, a dimensão positiva consiste na constitucionalização, ordenação e organização do poder. A primeira garante e protege a esfera dos indivíduos, evitando a concentração de poder. Já a segunda, assegura a

\footnotetext{
${ }^{35}$ CANOtilho, José Joaquim Gomes, Direito constitucional e teoria da constituição..., p. 246-248.

${ }^{36}$ Idem, p. 247.

${ }^{37}$ Idem, p. 248.

${ }^{38}$ Idem, p. 250.
} 
ordenação das funções do Estado, servindo de esquema de competências, tarefas, funções e responsabilidades dos órgãos constitucionais da soberania. ${ }^{39}$

Por fim, o quinto pressuposto seria a garantia de administração autônoma local, que tem relação com a problemática do princípio democrático, porquanto a democracia descentralizada possibilita uma maior participação dos cidadãos. O próprio autor admite que a conexão com o Estado de Direito não é tão clara, mas explica que a descentralização funciona como limite ao poder central. ${ }^{40}$

Expostos os pressupostos ao Estado de Direito, circunstâncias que possibilitam seu surgimento na realidade fática, há que se afirmar que o princípio do Estado de Direito propriamente dito é um conceito constitucionalmente caracterizado, uma forma de racionalização, cujos elementos podem ser identificados no texto fundamental. Canotilho afirma que, em geral, são considerados elementos do Estado de Direito a supremacia da Constituição; a legalidade da administração; a divisão dos poderes; a independência dos tribunais e a vinculação do juiz à lei (que pode estar englobada no item anterior); e a garantia da proteção jurídica, isto é, dos direitos fundamentais. ${ }^{41}$

Deste rol, podemos extrair dois elementos essenciais à discussão acerca da reserva de jurisdição, a divisão dos poderes e a garantia dos direitos fundamentais, os quais serão exaustivamente mencionados no decorrer deste trabalho.

Após essa breve explanação teórica, torna-se indispensável análise do Estado de Direito existente na Constituição do Brasil de 1988, de modo a identificar e analisar a presença desses elementos na estrutura erigida pelo Constituinte.

\footnotetext{
${ }^{39}$ CANOtilho, José Joaquim Gomes, Direito constitucional e teoria da constituição..., p. 250.

${ }^{40}$ Idem, p. 253.

${ }^{41}$ Idem, p. 255.
} 


\subsection{CARACTERIZAÇÃO DO ESTADO DEMOCRÁTICO DE DIREITO NO}

BRASIL

Nossa Constituição Cidadã incorporou os anseios da sociedade, abrindo perspectivas para a realização social profunda mediante a prática de direitos sociais e instrumentos de cidadania, fundando-se na dignidade da pessoa humana. ${ }^{42}$ Nesse sentido, o artigo $1^{\circ}$ da Constituição Federal do Brasil proclama e funda o Estado Democrático de Direito nos seguintes termos:

"Art. $1^{\circ}$ A República Federativa do Brasil, formada pela união indissolúvel dos Estados e Municípios e do Distrito Federal, constitui-se em Estado Democrático de Direito e tem como fundamentos:

I - a soberania;

II - a cidadania;

III - a dignidade da pessoa humana;

IV - os valores sociais do trabalho e da livre iniciativa;

$V$ - o pluralismo político.

Parágrafo único. Todo o poder emana do povo, que o exerce por meio de representantes eleitos ou diretamente, nos termos desta Constituição."

O regime democrático está consignado no parágrafo único, ao se afirmar que todo poder emana do povo. Observe-se, ainda, que a democracia estabelecida é a representativa,

${ }^{42}$ SILVA, José Afonso da, O Estado Democrático de Direito..., p.17; CORTEZ, Luís Francisco Aguilar, Judiciário e Democracia..., p. 167. 
uma vez que a Constituição fala em exercício do poder por meio de representantes. O princípio da soberania popular é, destarte, o fundamento maior do Estado Democrático de Direito, impondo a participação efetiva e operante do povo na coisa pública, possibilitando a garantia geral dos direitos fundamentais da pessoa humana. ${ }^{43}$

Os fundamentos previstos nos incisos do artigo são características decorrentes da adoção da democracia como fator legitimador da ordem jurídica brasileira e merecem atenção.

Segundo Miguel Reale, a soberania nacional é "o direito que cada Nação tem de preservar sua própria identidade cultural e salvaguardar seus próprios interesses". ${ }^{44} \mathrm{Com}$ efeito, pressupõe a exclusão da subordinação do povo e do Estado brasileiros a determinantes externas de conduta ou atuação. ${ }^{45}$

A cidadania e a dignidade da pessoa humana são fundamentos que devem ser interpretados conjugadamente, já que possuem íntima conexão. A cidadania pressupõe o respeito à dignidade da pessoa humana, uma vez que este confere a dimensão jurídicopolítica que cada cidadão adquire nos termos no artigo $5^{\circ}$ da Constituição. Além do mais, ambos são núcleos de irradiação dos demais direitos fundamentais. ${ }^{46}$

Alguns interpretam o valor da livre iniciativa como contrário ao princípio democrático. No entanto, ao consignar os valores sociais do trabalho e da livre iniciativa, o constituinte pretendeu apenas vedar a estatização da economia, sem que isso indique inobservância dos direitos sociais. ${ }^{47}$

\footnotetext{
${ }^{43}$ Silva, José Afonso da, O Estado Democrático de Direito..., p.13-15.

${ }^{44}$ ReALE, Miguel, O Estado Democrático de Direito..., p. 3.

${ }^{45}$ SiLVA, José Afonso da, O Estado Democrático de Direito..., p.13-15.

${ }^{46}$ Reale, Miguel, O Estado Democrático de Direito..., p. 3; Silva, José Afonso da, O Estado Democrático de Direito..., p.17.

${ }^{47}$ ReAle, Miguel, O Estado Democrático de Direito..., p. 4; SILVA, José Afonso da, O Estado Democrático de Direito..., p. 19 .
} 
Por fim, o pluralismo político deve ser visto como a vedação ao totalitarismo e o partido único, que impedem o desenvolvimento de uma sociedade participativa, bem como da efervescência de idéias típicas de uma democracia. ${ }^{48}$

Vale mencionar, também, que para José Afonso da Silva o verdadeiro Estado Democrático de Direito que tiver os fundamentos acima expostos deverá resultar na realização de alguns princípios relevantes, quais sejam: o princípio da constitucionalidade; o princípio democrático; a garantia da efetividade dos direitos fundamentais; o princípio da justiça social; o princípio da igualdade; e a divisão de poderes, esta última prevista no artigo $2^{\circ}$ da Constituição Federal. ${ }^{49}$

Miguel Reale defende, ainda, que os artigos $5^{\circ}$ e $6^{\circ}$ da Constituição brasileira, os quais trazem em seu bojo a definição dos direitos individuais e sociais, são desdobramentos do artigo $1^{\circ}$ ora em estudo, de maneira que também devem integrar o conceito de Estado Democrático de Direito. ${ }^{50}$ Isso porque o terceiro modelo de Estado não abandonou os preceitos do Estado Liberal e do Estado Social. Ao contrário, simboliza uma síntese de ambos com a adição dos princípios democráticos.

Essa breve análise diz respeito estritamente aos contornos do Estado Democrático de Direito delineado pela Constituição Federal brasileira de 1988. No entanto, para uma abordagem crítica completa, é imperiosa a correlação com os pressupostos e elementos do Estado de Direito preconizados por Canotilho e apresentados no item 2.3.

No que tange aos pressupostos, temos que a juridicidade é ínsita ao próprio conceito de Estado como ordem jurídica, nos termos dos itens iniciais deste estudo, sendo indiscutível sua presença no Estado brasileiro. A constitucionalidade também resta patente a partir do momento em que a ordem jurídica normativa fundamental do país é estruturada por meio de uma constituição. Mencionamos, desde já, a presença indiscutível da descentralização administrativa, haja vista o federalismo instituído.

\footnotetext{
${ }^{48}$ ReAle, Miguel, O Estado Democrático de Direito..., p. 4; Silva, José Afonso da, O Estado Democrático de Direito..., p.19.

${ }^{49}$ SILVA, José Afonso da, O Estado Democrático de Direito..., p. 20-21.

${ }^{50}$ Reale, Miguel, O Estado Democrático de Direito..., p. 3.
} 
Os dois pressupostos faltantes merecem atenção especial. Além de serem de extrema importância, ambos acabam implicando ou se relacionando com o que Canotilho denominou de elementos do Estado de Direito e foram por nós destacados como centrais nas discussões sobre as justificativas da reserva de jurisdição. Assim, passamos a analisálos, tratando, em seguida, dos demais elementos.

O sistema de direitos fundamentais é algo essencial ao Estado de Direito, e foi lembrado com honras pelo constituinte brasileiro. Com efeito, não obstante a dignidade da pessoa humana ter sido eleita como seu fundamento, os artigos $5^{\circ}$ e $6^{\circ}$ da Carta Magna e seus inúmeros incisos foram dedicados à construção de um sistema de direitos e garantias típicos de um Estado cuja preocupação central é o indivíduo, a pessoa humana. Lembrando que além do sistema ser um pressuposto para a existência do Estado de Direito, a garantia desses direitos é tida como um elemento do instituto, e os inúmeros mecanismos de proteção previstos nos dispositivos mencionados e em todo o texto constitucional comprovam sua existência no Estado brasileiro.

No que tange à divisão de poderes, pressuposto e elemento do Estado de Direito para Canotilho, ela está prevista no artigo $2^{\circ}$ da Constituição de 1988, conforme já mencionado acima, em dispositivo que deixa clara sua dimensão negativa, ao consignar a independência e harmonia dos poderes, claro mecanismo de controle recíproco que será analisado pormenorizadamente adiante. Outro elemento aludido pelo autor português que pode ser considerado corolário deste é a independência do Poder Judiciário, também insistentemente presente em nossa ordem jurídica.

Finalmente, o único elemento que não constitui pressuposto do Estado de Direito para Canotilho é o princípio da legalidade. Em última instância, por óbvio, acaba se relacionando com a idéia de juridicidade e respeito à lei, relação esta tão natural e evidente que, às vezes, deixa de ser mencionada expressamente.

Temos, portanto, que o Estado Democrático de Direito possui as características essenciais do Estado Liberal mencionadas em tópico anterior ${ }^{51}$, conjuntamente com as

\footnotetext{
${ }^{51}$ Primazia da lei e do sistema hierárquico de normas, observância da legalidade por parte da administração, divisão dos poderes estatais e o reconhecimento e garantia dos direitos individuais.
} 
características decorrentes da adoção do regime democrático, que Canotilho divide em pressupostos e elementos e nós as identificamos na ordem jurídica brasileira.

Diante da relevância extrema de três dos elementos estudados e das reiteradas alusões feitas pelos autores consultados, eles serão explorados com maior profundidade, até porque são erigidos por muitos como verdadeiros pilares do atual Estado Democrático de Direito brasileiro: o princípio da primazia da lei; a dignidade da pessoa humana; e a independência dos poderes.

\subsubsection{SUBMISSÃO À LEI}

Como exposto acima, a primazia da lei é um princípio que surgiu com vistas a limitar o poder absoluto exercido pelos monarcas até o século XVI, que possuíam livre atividade criadora. Segundo Pablo Lucas Verdú, a formalização do Direito, a partir da qual o Estado insere-se na juridicidade, iniciou-se com a escola naturalista protestante, que vai de Grócio a Kant. A partir de então, a lei passa a ser vista como esquema geral, formal e obrigatório, apoiada na força do aparato estatal. ${ }^{52}$

E se a lei, ou melhor, o Direito, é fruto da vontade do povo, ainda que por meio da representação parlamentar, todos devem se submeter a ela, inclusive e, sobretudo, o governante, evitando-se, assim, o cometimento de atos com abuso de poder. Essa é a razão maior de ser do surgimento do Estado de Direito.

Segundo escólio de José Afonso da Silva, a submissão ao império da lei é a nota primária do conceito de Estado de Direito, considerando-se a lei como ato formalmente emanado do Poder Legislativo, o qual se compõe de representantes do povo. Essa lei deve ser geral e abstrata, para que dela deflua a igualdade. ${ }^{53}$ Já sabemos que essa igualdade é meramente formal se à legalidade não forem acrescentados elementos democráticos, razão

\footnotetext{
${ }^{52}$ Verdú, Pablo Lucas, A luta pelo Estado de Direito..., p. 16.

${ }^{53}$ SILVA, José Afonso da, Curso de direito constitucional positivo..., p. 112-118.
} 
pela qual para que haja um verdadeiro Estado de Direito, não basta a submissão à lei, sendo necessários, no mínimo, o respeito à dignidade humana e a divisão de poderes.

Muito pertinente é a transcrição de um trecho da obra de José Joaquim Gomes Canotilho em que discorre sobre o tema:

“O princípio da legalidade postula dois princípios fundamentais: o princípio da supremacia ou prevalência da lei (Vorrang des Gesetzes) e o princípio da reserva de lei (Vorbehalt dês Gesetzes). Estes princípios permanecem válidos, pois num Estado democrático-constitucional a lei parlamentar é, ainda, a expressão privilegiada do princípio democrático (daí sua supremacia) e o instrumento mais apropriado e seguro para definir os regimes de certas matérias, sobretudo dos direitos fundamentais e da vertebração democrática do Estado (daí a reserva de lei). "54

De qualquer maneira, resta patente que a legalidade foi um parâmetro implementado para proporcionar aos cidadãos tratamento digno e equânime. Digno porquanto não serão admitidos atos abusivos por parte dos detentores do poder e equânime porquanto todos receberão o mesmo tratamento de acordo com os ditames legais. Nesse sentido, Miguel Reale aduz que o princípio da legalidade:

“consiste em não pretender que a vontade individual ou coletiva seja superior à vontade objetivamente consubstanciada nos mandamentos da Constituição e das Leis. "

\footnotetext{
${ }^{54}$ CANOTILHo, José Joaquim Gomes, Direito constitucional e teoria da constituição..., p. 256.

${ }^{55}$ Reale, Miguel, $O$ Estado Democrático de Direito..., p. 9.
} 
Observe-se que o conceito de legalidade evoluiu a ponto de desenvolver diversos vieses. Sob o ponto de vista de um cidadão comum, a legalidade é um direito negativo, por assegurar que não será obrigado a fazer ou deixar de fazer nada se não houver uma lei que lhe imponha o dever. Mas sob o ponto de vista do Estado, que é o verdadeiro desenvolvimento da primazia da lei atinente aos primórdios do Estado de Direito, traz a idéia de que a administração só pode ser exercida em conformidade com a lei. É o que se denomina legalidade estrita. ${ }^{56}$

A primazia da lei, portanto, contrapõe-se a qualquer exacerbação personalista dos governantes e opõe-se a qualquer forma de autoritarismo, pois sua raiz é a idéia de soberania popular, na medida em que o poder emana do povo e os executores do poder são meros representantes deles. Como tais, devem observar estritamente os enunciados legais, que nada mais são do que a expressão da vontade do povo. ${ }^{57}$

Adiante, veremos que a existência de um órgão judicial é fulcral para garantir a legalidade. Antes, porém, cumpre discorrer sobre a dignidade da pessoa humana.

\subsubsection{RESPEITO À DIGNIDADE DA PESSOA HUMANA}

A idéia do ser humano como valor absoluto originou-se com o surgimento do Cristianismo e consolidou-se após a obra de Kant sobre o tema, para quem o ser humano é um fim em si mesmo e a dignidade humana seria decorrente da razão e liberdade humanas. $^{58}$

\footnotetext{
${ }^{56}$ Mello, Celso Antonio Bandeira de, Curso de Direito Administrativo, $25^{\mathrm{a}}$ Ed. rev. e atual. até a EC 56 de 10.12.2007, São Paulo, Malheiros Editores, 2008, p. 101 e 105. Observe-se que a legalidade como direito do cidadão é prevista no inciso II do artigo $5^{\circ}$ da Constituição Federal, enquanto que a legalidade a que se submete o aparato estatal, está consignada no artigo 37, caput, da mesma.

${ }^{57}$ Mello, Celso Antonio Bandeira de, Curso de Direito Administrativo..., p. 100-101.

${ }^{58}$ Costa, Helena Regina Lobo da, A Dignidade Humana: teorias de prevenção geral positiva, São Paulo, Editora Revista dos Tribunais, 2008, p. 21 e 24; GARCIA, Edinês Maria Sormani, O fundamento da consagração da pessoa humana no texto constitucional brasileiro de 1988, in 15 anos da Constituição Federal: em busca da efetividade, José Roberto Martins Segalla e Luiz Alberto David Araujo (coord.), Bauru, EDITE, 2003, p. 212; WAJngarten, Aron e BriAni, Alberto, Aplicação do Princípio da Dignidade
} 
Segundo Miguel Reale, o valor da pessoa humana é:

"valor fonte, ou seja, aquele do qual emergem todos os valores, os quais somente não perdem sua força imperativa e sua eficácia enquanto não se desligam da raiz de que promanam. "59

Por isso, o princípio da dignidade da pessoa humana é considerado o fundamento filosófico dos direitos fundamentais, expressando-se por meio deles. O princípio da dignidade da pessoa humana é uma diretriz estrutural e axiológica que determinou a inscrição dos direitos fundamentais em nossa Constituição e, ainda, exerce influência sobre o trabalho hermenêutico do legislador, do administrador e do julgador. Note-se que prevaleceu uma conceituação ampla dele, abrangendo tanto os direitos individuais quanto os sociais. $^{60}$

Conforme preleciona Flávia Piovesan, os direitos fundamentais são elemento básico de realização do princípio democrático. A Constituição de 1988 elegeu a dignidade da pessoa humana como valor essencial, o que significa que a pessoa é o fim e o fundamento da sociedade e do Estado e, conseqüentemente, da ordem jurídica. ${ }^{61}$

A dignidade da pessoa humana não é apenas princípio fundamental da constituição, mas também de todo ordenamento jurídico e das ações estatais. Com sua positivação, fica

Humana, in 15 anos da Constituição Federal: em busca da efetividade, José Roberto Martins Segalla e Luiz Alberto David Araujo (coord.) Bauru, EDITE, 2003, p.41; TAVARES, André Ramos, Princípio da Dignidade da Pessoa Humana, in 15 anos da Constituição Federal: em busca da efetividade, José Roberto Martins Segalla e Luiz Alberto David Araujo (coord.) Bauru, EDITE, 2003, p. 16.

${ }^{59}$ ReAle, Miguel, O Estado Democrático de Direito..., p. 100.

${ }^{60}$ Costa, Helena Regina Lobo da, A Dignidade Humana..., p. 31 e 37; MoraEs, Maurício Zanoide de, Presunção de inocência no Processo Penal Brasileiro: análise de sua estrutura normativa para a elaboração legislativa e para a decisão judicial, Tese apresentada à Egrégia Congregação da Faculdade de Direito da Universidade de São Paulo como exigência parcial à obtenção do título de Livre-Docência em Direito Processual Penal, São Paulo, 2008, p. 227.

${ }^{61}$ Piovesan, Flavia, Direitos Humanos e o direito constitucional internacional, $7^{\text {a }}$ ed. rev., ampl. e atual., São Paulo, Editora Saraiva, 2006, p. 26-28; WAJNGARTEN, Aron e BriAnI, Alberto, Aplicação do Princípio da Dignidade Humana..., p.40. 
claro que o homem é o início e o fim da sociedade, do Estado e do Direito, não sendo o meio para a consecução de algum outro objetivo. ${ }^{62}$

Nesse sentido, o Estado existe em função de todas as pessoas e não o contrário. $\mathrm{O}$ mesmo deve ser dito com relação ao Direito. Uma prova disso no direito posto é que o capítulo referente aos direitos fundamentais em nossa Constituição antecede ao capítulo que trata da organização do Estado. ${ }^{63}$ Outrossim, deve ser destacado que a forma com que a Constituição Federal de 1988 protege a pessoa humana denota que ela é o valor supremo da democracia, raiz antropológica constitucionalmente estruturante do Estado. ${ }^{64}$

O seguinte excerto de Edílson Pereira Farias expressa muito bem o papel exercido pela pessoa humana na ordem jurídica:

"A pessoa humana é hoje considerada como o mais eminente de todos os valores porque constitui a fonte e a raiz de todos os demais valores. Representa 'a fonte principal de enriquecimento e de dinamismo da sociedade'. Por conseguinte, a pessoa humana expressa a fonte e a base mesma do direito, revelando-se, assim, critério essencial de legitimidade da ordem jurídica. ${ }^{165}$

No âmbito específico do Processo Penal também se constata que o ser humano é um valor supremo contra o qual o Estado não pode perpetrar nenhuma ação violadora. Isso porque os direitos fundamentais dirigidos a este ramo jurídico exigem que as investigações sejam levadas a cabo respeitando-se os limites e formas legítimas. ${ }^{66}$

Assim, retomando a idéia de Estado de Direito material abordada em tópico anterior, afirmamos que ele só será realizado plenamente se houver respeito à dignidade

\footnotetext{
${ }^{62}$ Moraes, Maurício Zanoide de, Presunção de inocência..., p. 236-237.

${ }^{63}$ Wajngarten, Aron e Briani, Alberto, Aplicação do Princípio da Dignidade Humana..., p. 41; TAVARES, André Ramos, Princípio da Dignidade da Pessoa Humana..., p. 27.

${ }^{64}$ GARCIA, Edinês Maria Sormani, O fundamento da consagração da pessoa humana..., p. 224.

${ }^{65}$ FARIAS, Edilson Pereira, Colisão de Direitos: a honra, a intimidade, a vida privada e a imagem versus a liberdade de expressão e informação, 2ed. atual., Porto Alegre, Sergio Antonio Fabris Editor, 2000, p. 56.

${ }^{66}$ Moraes, Maurício Zanoide de, Presunção de inocência..., p. 233.
} 
humana e aos direitos fundamentais. O Estado Democrático de Direito, ao contrário do Estado Legal, não se legitima por meio da mera subordinação à lei. É necessário, também, que se observem os valores fundamentais consubstanciados na dignidade humana. ${ }^{67}$ Por tal razão, temos que o princípio da dignidade da pessoa humana é um dos grandes pilares do modelo de Estado Democrático de Direito. ${ }^{68}$

Diante de tamanha importância, é essencial que exista um órgão com atributos que permitam promover sua proteção da melhor maneira possível. Nessa estrutura estatal exposta, este órgão é o Poder Judiciário e nenhum outro poderá se imiscuir nessa atividade. O porquê dessa conjuntura começa a ser explicado pelo estudo da teoria da separação dos poderes, o que passamos a fazer no item seguinte.

\subsubsection{PODERES HARMÔNICOS E INDEPENDENTES ENTRE SI}

Os teóricos do século XVII, como Locke e Montesquieu, conceberam a regra técnica da separação de poderes como meio de garantir o primado da lei e a limitação do poder, com vistas a proteger os direitos fundamentais. Em suma, a teoria da separação dos poderes foi concebida com vistas a garantir o Estado de Direito. Por tal razão, foi consignada na Declaração de Direitos do Homem e do Cidadão como requisito indispensável em uma constituição. ${ }^{69}$

A evolução dessa teoria até os dias atuais possui inúmeros fatores relevantes para o objeto deste estudo, em função do que será tratada em item específico. No entanto, por ora, basta afirmar que o artigo $2^{\circ}$ da Constituição Federal de 1988 consagrou a divisão de poderes do Estado Democrático de Direito brasileiro nos seguintes termos: "são poderes da União, independentes e harmônicos entre si, o Legislativo, o Executivo e o Judiciário".

\footnotetext{
${ }^{67}$ Costa, Helena Regina Lobo da, A Dignidade Humana..., p. 37.

${ }^{68}$ GARCIA, Edinês Maria Sormani, O fundamento da consagração da pessoa humana..., p. 222.

69 Verdú, Pablo Lucas, A luta pelo Estado de Direito..., p. 4; COELHO, Inocêncio Mártires, O Perfil Constitucional do Estado Contemporâneo..., p. 10; TAVARES, André Ramos, Repartição de funções estatais: fundamento, estrutura e finalidade, in Revista do Advogado, Ano XXIII, n. ${ }^{\circ}$ 73, novembro de 2003, p. 21-23.
} 
Extrai-se do texto constitucional que não foi imposta ao Brasil a teoria radical de separação total de poderes pregada por alguns que, como se verá, sequer foi defendida por Montesquieu. A organização dos Poderes de Estado brasileiros tem grande influência da teoria dos freios e contrapesos elaborada pelos teóricos norte-americanos e, em virtude disso, deve obedecer a essas duas premissas: independência e harmonia.

Segundo José Afonso da Silva:

"A independência dos poderes significa: (a) que a investidura e permanência das pessoas num dos órgãos do governo não dependem da confiança nem da vontade dos outros; (b) que, no exercício das atribuições que lhes sejam próprias, não precisam os titulares consultar os outros nem necessitam de sua autorização; (c) que, na organização dos respectivos serviços, cada um é livre, observadas apenas as disposições constitucionais e legais. "70

Sendo assim, todos os Poderes do Estado possuem total liberdade para o exercício de suas competências, sem que os demais se imiscuam em seus assuntos. Todavia, para não haver uma total segmentação da atuação governamental, tendo em vista a unicidade do poder, há que se observar a harmonia em sua atuação.

A cortesia deve pautar a conduta de todos os órgãos representantes dos Poderes estatais, havendo respeito recíproco às prerrogativas e faculdades de cada um. Por outro lado, com vistas a atingir o equilíbrio necessário à realização do bem da coletividade, evitando-se arbítrios e desmandos, a Constituição Federal permite, em alguns casos, interferências de um Poder no outro, de modo que a independência preconizada acima não pode ser tomada como absoluta. Exemplos dessas ingerências são o poder de veto do

${ }^{70}$ SiLVA, José Afonso da, Curso de direito constitucional positivo..., p. 110. 
Presidente da República em face de atos legislativos e a declaração de inconstitucionalidade das leis por parte dos tribunais. ${ }^{71}$

A existência de uma colaboração entre os Poderes estatais é facilmente depreendida do exposto, sendo um dos pilares que sustentam o atual Estado Democrático de Direito.

O tema, no entanto, enseja grandes discussões quando adentramos ao estudo de cada uma das funções exercidas pelos poderes, tarefa que devemos empreender, haja vista o objeto deste trabalho. Com efeito, pretendemos delinear com exatidão a função que deve ser exercida por cada um dos Poderes estatais para, então, demonstrar que a função essencial do Poder Judiciário não pode ser exercida por qualquer outro órgão. Além disso, pretendemos provar que a restrição de direitos fundamentais na aplicação da lei a casos concretos não está contida no rol de atribuições relativas à função legislativa.

Destarte, faremos uma breve exposição acerca da teoria da separação dos poderes para, depois, examinar pormenorizadamente o conteúdo das funções exercidas por cada um deles. Considerando a amplitude do assunto, ele será abordado em tópico específico.

\subsection{DAS FUNÇÕES ESSENCIAIS AO ESTADO E SUA DIVISÃO}

\subsubsection{DA EVOLUÇÃO DA TEORIA DA SEPARAÇÃO DOS}

\section{PODERES}

Embora a teoria da separação dos poderes só tenha ganhado corpo e divulgação no século XVII, sua elaboração remete à Antiguidade, quando Platão e Aristóteles desenvolveram a teoria da constituição mista e sua idéia de equilíbrio de forças diversas. ${ }^{72}$

${ }^{71}$ Silva, José Afonso da, Curso de direito constitucional positivo..., p. 110-111. 
Já sob a influência do movimento iluminista, John Locke delineou a existência de três Poderes no Estado, o Legislativo, que seria responsável pela edição de leis; o Executivo, a quem caberia a aplicação das leis; e o Federativo, cuja atribuição era cuidar das relações exteriores, sobretudo de assuntos ligados a paz e guerra. Enquanto o Poder Legislativo deveria ser exercido pelo Parlamento, os demais eram conferidos ao monarca. ${ }^{73}$ Como se percebe, o autor inglês não mencionou o Poder Judiciário. ${ }^{74}$

Mas foi Mostesquieu, estudioso francês que se debruçou sobre a realidade inglesa, que elaborou a grande sistematização sobre a separação de poderes na obra "Do Espírito da Leis”. O autor norteou-se pela idéia de pessimismo antropológico, partindo do pressuposto de que todo aquele que possui poder sem limites tende a se corromper, de modo que devem ser criados mecanismos que impeçam qualquer abuso. ${ }^{75}$

O estudioso transplantou para âmbito da teoria política uma visão mecanicista do universo, em que os três órgãos do Estado apresentariam um equilíbrio semelhante àquele que se verifica na trajetória dos astros. ${ }^{76}$

A teoria de Montesquieu vislumbrou três funções, as quais deveriam ser desempenhadas por três órgãos, ou centros de autoridade, distintos, os quais foram denominados de poderes em sua obra. ${ }^{77}$ Karl Lowenstein esclarece que a teoria da separação de poderes significa que, por um lado, o Estado tem de cumprir várias funções e, por outro, os cidadãos são beneficiados quando elas são exercidas por diferentes órgãos.

\footnotetext{
${ }^{72}$ ReIS, José Carlos Vasconcellos dos, Controle externo do Poder Judiciário e Separação de Poderes, in Direito Constitucional Brasileiro - perspectivas e controvérsias contemporâneas, Regina Quaresma e Maria Lúcia de Paula Oliveira (coord.), Rio de Janeiro, Editora Forense, 2006, p. 195; RussomANo, Rosah, Curso de Direito Constitucional, $5^{\text {a }}$ ed. rev. e atual., Rio de Janeiro, Freitas Bastos Editora, 1997, 136; CORTEZ, Luís Francisco Aguilar, Judiciário e Democracia..., p. 171.

${ }^{73}$ ReIS, José Carlos Vasconcellos dos, Controle externo do Poder Judiciário... p. 196; Russomano, Rosah, Curso de Direito Constitucional..., p. 137

${ }^{74}$ ReIS, José Carlos Vasconcellos dos, Controle externo do Poder Judiciário..., p. 197; CoRTEZ, Luís Francisco Aguilar, Judiciário e Democracia..., p. 171.

${ }^{75}$ ReIS, José Carlos Vasconcellos dos, Controle externo do Poder Judiciário..., p. 197; TAVARES, André Ramos, Repartição de funções estatais..., p. 22.

${ }^{76}$ ReIS, José Carlos Vasconcellos dos, Controle externo do Poder Judiciário..., p.. 197.

77 KorZeniaK, Jose, La separacion de los poderes del gobierno, in Defensa de La Constitucion Nacional, Facultad de Derecho y Ciencias Sociales, Montevideo, 1986, p. 25; RuSsomano, Rosah, Curso de Direito Constitucional..., p. 137.
} 
Trata-se, portanto, de uma distribuição de funções estatais com o escopo de controlar o arbítrio. $^{78}$

Rosah Russomano afirma que o Montesquieu tratou do Poder Legislativo, Poder Executivo do Direito Internacional e Poder Executivo do Direito Civil, mas os demais autores costumam adaptar a terminologia, falando em Poder Legislativo, Executivo e Judicial, respectivamente. ${ }^{79}$

Com efeito, para Montesquieu, a função legislativa seria aquela responsável pela elaboração das leis gerais e abstratas, podendo alterá-las ou ab-rogá-las. O Poder Executivo do Direito Internacional, ou apenas executivo, trata dos assuntos de guerra e paz, defende a soberania, ou seja, cuida das relações internacionais e executa as leis. Finalmente, o Poder Executivo do Direito Civil, ou Judicial, tem a atribuição de punir os crimes ou julgar as querelas dos indivíduos. Cumpre ressaltar que o Poder Executivo deve ser exercido pelo monarca, porquanto necessite de uma ação imediata; o Legislativo deve ser confiado aos representantes do povo; e o Poder de julgar deve ser exercido por pessoas extraídas do corpo do povo que possuam mandatos temporários. ${ }^{80}$

Merece destaque a dissidência existente entre os autores acerca da natureza do Poder Judicial. É fato que, para o autor, o Judiciário deveria ser apenas a "boca que pronuncia as sentenças da lei”. Em vista disso, Antonio Umberto de Souza Junior entende que o Judiciário seria nulo, como resposta à desconfiança que existia com relação ao magistrado da fase absolutista. ${ }^{81}$ Já Luiz Francisco Aguilar Cortez propugna que a função judicial é residual nesse contexto, uma vez que não possui autonomia e os tribunais não seriam permanentes. ${ }^{82}$ Dalmo Dallari esclarece que a limitação da atribuição de julgar do Estado decorre de uma excessiva preocupação com a liberdade individual, deixando-se de

\footnotetext{
${ }^{78}$ Lowenstein, Karl, Teoría de La Constitución, Alfredo Gallego Anabitarte (trad.), Barcelona, Ediciones Ariel, 1970. p. 55.

${ }^{79}$ KorzeniaK, Jose, La separacion de los poderes del gobierno..., p. 25; Russomano, Rosah, Curso de Direito Constitucional..., p. 137.

${ }^{80}$ KorZENIAK, Jose, La separacion de los poderes del gobierno..., p. 25; RUSSOMANO, Rosah, Curso de Direito Constitucional..., p. 137; REIS, José Carlos Vasconcellos dos, Controle externo do Poder Judiciário..., p. 198.

${ }^{81}$ SoUZA JUNIOR, Antonio Umberto de, Entre a primeira e a última palavras ensaio sobre a amplitude da reserva constitucional de jurisdição, in Revista da Faculdade de Ciências Jurídicas e Sociais do Centro Universitário de Brasília, n. ${ }^{\circ}$ 13, janeiro/junho 2006, p. 79.

${ }^{82}$ CORTEZ, Luís Francisco Aguilar, Judiciário e Democracia..., p. 171.
} 
lado a eficiência da atividade. ${ }^{83}$ Nesse sentido, é pertinente a transcrição do seguinte excerto:

"Quanto à função de julgar, vê-se o relevo dado por Montesquieu, e pelos Iluministas em geral, à legalidade como proteção dos direitos individuais, naquele momento histórico em que o processo, de caráter inquisitorial, colocada acusados à mercê do julgador. ",84

De todo o exposto, percebe-se que Montesquieu sempre pregou o controle recíproco, expondo uma realidade de combinação de poderes. Foi a Revolução Francesa que deturpou a teoria e exagerou na idéia de separação das funções. Outrossim, a expressão poder referia-se tão somente a elas, e não a órgãos subjetivos. ${ }^{85}$

Para evitar que a excessiva rigidez dos limites entre as funções prejudicasse a harmonia propugnada, foi elaborado por Bolinbroke o sistema de checks and balances (freios e contrapesos). O escopo era justamente permitir o controle recíproco entre os órgãos estatais, autorizando seu entrosamento com harmonia. Esse modelo aperfeiçoado pelos federalistas, comprometidos com a democracia, aumentou a relevância do papel desempenhado pelo Judiciário, que seria o responsável pela fiscalização da observância das regras e princípios que garantiriam o equilíbrio. ${ }^{86}$

${ }^{83}$ DALlari, Dalmo de Abreu, Elementos de Teoria Geral do Estado..., p. 218.

${ }^{84}$ ReIS, José Carlos Vasconcellos dos, Controle externo do Poder Judiciário..., p. 198-199.

${ }^{85}$ Russomano, Rosah, Curso de Direito Constitucional..., p. 139.

${ }^{86}$ Idem, p. 140; SOUZA JUNIOR, Antonio Umberto de, Entre a primeira e a última palavras..., p. 80-81; 


\subsubsection{CONTEÚDO DAS FUNÇÕES}

Canotilho explica que, ao se falar em separação de poderes, não se está referindo a uma repartição do próprio poder do Estado, mas sim à divisão da sua atividade, de modo a resultar na existência de diversas funções estatais diferenciadas. ${ }^{87}$ Para melhor compreender o tema, imprescindível a definição da idéia de função e sua relação com os órgãos e Poderes estatais.

Jorge Miranda preleciona que a expressão "função do Estado" pode ser dotada de dois sentidos: o primeiro seria relacionado com a idéia de necessidade coletiva, finalidade estatal, e sofre grande alargamento em virtude do crescimento exponencial das necessidades humanas; ${ }^{88}$ já o segundo sentido denotaria os atos e atividades desenvolvidos pelo Estado, sendo manifestação específica do poder político. Nesta última acepção, a função deve ser entendida como meio para atingir o fim. ${ }^{89}$

Neste sentido de atividade, a função se caracteriza como um complexo ordenado de atos destinados a um ou vários fins. Apresenta como características: a permanência; o fato de ser um conjunto de atos; e as especificidades que lhe são atribuídas por seus elementos materiais (suas causas ou resultados), formais (seus trâmites) e orgânicos (os quais se revelam por seus agentes). ${ }^{90}$

Observe-se que a determinação do órgão ou agente ao qual será atribuído o exercício da função é apenas um de seus elementos caracterizadores, de maneira que devemos dar especial atenção ao conteúdo material da função para diferenciá-la das demais e mais ainda às características que lhe são atribuídas pelo próprio Direito. Na verdade,

\footnotetext{
${ }^{87}$ CANOTILHO, José Joaquim Gomes, Direito constitucional e teoria da constituição..., p. 551 e 552.

${ }^{88}$ Nesse sentido, esclarecedor o trecho da obra de Celso Antonio Bandeira de Mello, para o qual "função pública, no Estado Democrático de Direito, é a atividade exercida no cumprimento do dever de alcançar o interesse público, mediante o uso dos poderes instrumentalmente necessários conferidos pela ordem jurídica. ”Cf. Mello, Celso Antonio Bandeira de, Curso de Direito Administrativo..., p. 29.

${ }^{89}$ MIRANDA, Jorge, Teoria do Estado e da Constituição, Coimbra, Coimbra Editora, 2002, p. 335-338.

${ }^{90}$ Idem, p. 338.
} 
como se verá a seguir, a criação de órgãos especializados é uma consequiência da própria divisão de funções. ${ }^{91}$

Marcello Caetano é adepto da discriminação material das funções e qualifica como jurídicas aquelas que tendem a estabelecer ou criar e aplicar o direito. $\mathrm{O}$ autor enquadra nesta categoria as três funções tradicionalmente mencionadas pela doutrina, sendo legislativa a função de criar a lei e executiva a de aplicar, seja esta aplicação feita pelos tribunais, seja pela administração. ${ }^{92}$ Alguns autores, ainda, como Jorge Miranda, classificam as funções estatais em administrativa, jurisdicional e política, a qual se subdivide em legislativa e governativa. ${ }^{93}$

Em que pese a coerência das classificações acima apontadas, em geral, os autores identificam três funções, na esteira da teoria desenvolvida por Montesquieu e apresentada no tópico anterior: a legislativa, a administrativa e a jurisdicional. Esta divisão é facilmente identificada na ordem jurídica brasileira e, por tal razão, será por nós adotada para a análise pormenorizada de seu conteúdo material, com vistas a nos guiar na empreitada de identificar a atividade exclusivamente jurisdicional, objetivo proposto por este estudo.

No entanto, adicionaremos uma quarta função ao estudo, a de controle. Na verdade, todos os órgãos que compõe a estrutura do Poder soberano exercem controle um sobre os outros pela simples divisão de tarefas aplicada. Esta é a essência da teoria dos freios e contrapesos. Mas há, ainda, o que podemos chamar de controle específico, o que significa que um determinado órgão pode impedir a realização de um ato por parte de um outro órgão.

\footnotetext{
${ }^{91}$ Celso Antonio Bandeira de Mello esclarece que alguns autores utilizam o denominado critério subjetivo para diferenciar as funções estatais, o qual identifica a função com base em quem a produz. No entanto, este critério seria insatisfatório, uma vez que inexiste correspondência exata entre um conjunto orgânico e uma função, mas apenas uma predominância da atividade típica. Alguns autores utilizam o chamado critério objetivo material, o qual busca identificar a função a partir de seus elementos intrínsecos. Este critério também seria inadequado, pois em direito, uma coisa o é pela qualificação que lhe é atribuída, e não pela essência do objeto. Assim, o critério adequado seria o objetivo formal, segundo o qual as funções do Estado são caracterizadas pelo tratamento normativo que lhes é dado. Cf. MELLo, Celso Antonio Bandeira de, Curso de Direito Administrativo..., p. 32-36. Concordamos com o autor sobre a ineficácia do critério subjetivo. No entanto, acreditamos que o critério objetivo material deve ser valorizado ao lado do critério objetivo formal.

${ }^{92}$ Caetano, Marcello, Manual de Direito Administrativo, $10^{\mathrm{a}}$ ed., $2^{\mathrm{a}}$ reimp., Tomo I, Coimbra, Livraria Almedina, 1982, p. 7-13.

${ }^{93}$ MIRANDA, Jorge, Teoria do Estado e da Constituição..., p. 344.
} 
Essa é a visão de Karl Lowenstein, o qual afirma ser a função de controle dupla em um Estado Constitucional. Por um lado, se expressa mediante a atuação conjunta dos órgãos detentores do poder, o que traz em seu bojo a idéia de distribuição do poder e limitação recíproca. Por outro, pode indicar o controle específico de um órgão sobre o outro, quando é conferida a um órgão a possibilidade de impedir a atuação de outro em determinados casos, ensejando até mesmo a responsabilidade política. É o que se observa na função de controle expressamente atribuída ao Poder Legislativo, a qual será abordada adiante. $^{94}$

Antes, deve-se lembrar que essa separação de tarefas implica a existência de uma estrutura orgânica funcionalmente adequada, a qual pressupõe a atribuição do exercício da atividade específica ao órgão cujas características permitem seu desempenho da forma mais adequada possível. É comum denominar esses órgãos de poderes, mas, como já dito anteriormente, não ocorre uma efetiva separação de poderes, mas sim de atividades ou funções. Como é sabido, o poder estatal é uno e, como tal, não admite segmentações. ${ }^{95}$

De qualquer maneira, esta é a nomenclatura adotada em nosso texto constitucional, de modo que, feito o alerta sobre o equívoco de sua utilização, faremos menção constante aos Poderes Legislativo, Executivo e Judiciário, destacando que cada um deles absorve, com manifesta predominância, as funções correspondentes a suas denominações. ${ }^{96}$ Faremos, agora, uma análise de cada uma das funções primordiais do Estado moderno, colocando a função de controle ao lado da função legislativa uma vez que, em nosso ordenamento, ambas são tipicamente exercidas pelo mesmo órgão.

\footnotetext{
${ }^{94}$ LOWEnsteIn, Karl, Teoría de La Constitución..., p. 70.

${ }_{95}$ CANOTILHO, José Joaquim Gomes, Direito constitucional e teoria da constituição..., p. 552.

${ }^{96}$ Mello, Celso Antonio Bandeira de, Curso de Direito Administrativo..., p. 31.
} 


\subsubsection{FUNÇÃO ADMINISTRATIVA}

Nos termos da teoria de Marcello Caetano, a função administrativa é uma função executiva, uma vez que mediante seus órgãos o Estado promove a aplicação da lei. Por meio dela, são realizados os interesses públicos e as necessidades coletivas. ${ }^{97}$

Celso Antonio Bandeira de Mello define-a assim:

"Função Administrativa é a função que o Estado, ou quem lhe faça as vezes, exerce na intimidade de uma estrutura e regime hierárquicos e que no sistema constitucional brasileiro se caracteriza pelo fato de ser desempenhada mediante comportamentos infralegais ou, excepcionalmente, infraconstitucionais, submissos todos a controle de legalidade pelo Poder Judiciário. "98

É por meio da função administrativa que se realiza a prossecução dos interesses públicos, isto é, o órgão responsável por sua execução atua no sentido de atender às necessidades coletivas nos termos da lei. Caracteriza-se por possibilitar ao agente ter iniciativa própria, sendo desnecessária a provocação de um cidadão para originar sua atuação. ${ }^{99}$

A parcialidade é ínsita à função administrativa, uma vez que o órgão que a exerce é parte das relações a que se referem seus atos. Todavia, não é uma parte comum, agindo, em geral, com superioridade. Por tal razão é vista como autoritária, impondo-se às demais partes. $^{100}$

${ }^{97}$ CAETAno, Marcello, Manual de Direito Administrativo..., p. 13; MIRANDA, Jorge, Teoria do Estado e da Constituição..., p. 344.

${ }_{98}^{98}$ Mello, Celso Antonio Bandeira de, Curso de Direito Administrativo..., p. 36.

${ }^{99}$ MIRANDA, Jorge, Teoria do Estado e da Constituição..., p. 364.

${ }^{100}$ Idem, p. 364. 
Comumente, a função administrativa é relacionada ao chamado Poder Executivo, pois efetua a execução da lei. Tal Poder é representado pelo governante e pela estrutura a ele vinculada. ${ }^{101}$ Assim faz a Constituição Brasileira de 1988 em seu artigo 76, in verbis:

“Art. 76 - O Poder Executivo é exercido pelo Presidente da República, auxiliado pelos Ministros de Estado."

Conquanto o texto constitucional não relacione expressamente o Poder Executivo à função administrativa, tal ligação fica clara ao se analisar o conteúdo das atribuições do Presidente da República, enumeradas no Capítulo II do Título IV, que trata da Organização dos Poderes, sobretudo o inciso II do artigo 84, segundo o qual compete ao Presidente da República exercer, com auxílio dos Ministros do Estado, a direção superior da administração pública federal.

Ressalte-se, todavia, que esta é apenas a função típica exercida pelo Poder Executivo, isto é, aquela que exerce predominantemente, e a qual só admite invasões na medida em que não for atingido seu núcleo essencial. Isso significa que tanto é possível que este órgão exerça outras funções que não lhe são peculiares, com a edição de atos legislativos ou a realização de julgamentos, quanto é possível o exercício da função administrativa por outros Poderes, como será mais bem explicado adiante.

\footnotetext{
${ }^{101}$ Não se olvide que na estrutura do Estado Federal Brasileiro, há, ainda, a divisão do Estado em entes federativos, o que enseja a existência do Poder Executivo específico em todas essas esferas, assunto que não será abordado neste estudo por fugir ao tema proposto.
} 


\subsubsection{FUNÇÃO LEGISLATIVA E DE CONTROLE}

\section{ESPECÍFICO}

Na definição de Celso Antonio Bandeira de Mello:

“... função legislativa é a função que o Estado, e somente ele, exerce por via de normas gerais, normalmente abstratas, que inovam inicialmente na ordem jurídica, isto é, que se fundam direta e imediatamente na Constituição. ",102

O órgão responsável pelo exercício desta função é aquele que elabora as leis e atos legislativos em geral que regem a vida em sociedade. Na Constituição Federal de 1988, tal tarefa é atribuída ao Poder Legislativo pelo artigo 44, o qual, no âmbito federal, é exercido pelo Congresso Nacional, composto pela Câmara dos Deputados e pelo Senado Federal.

Anote-se, todavia, que as atividades do Poder Legislativo não se resumem à elaboração de normas. Os diversos dispositivos legais do Capítulo I, Título IV da Constituição brasileira, dispõem que incumbe a este órgão, entre outras coisas, fiscalizar e controlar os atos do Poder Executivo e julgar a prestação de contas do Presidente da República (incisos IX e X do artigo 49 da CF de 1988).

Luiz Carlos dos Santos Gonçalves ensina que a função originária do Poder Legislativo era o controle do poder e representação popular, e não a edição de leis propriamente ditas. Tal controle pode ser exercido de diversas maneiras, tais como a aprovação de contas pelo Congresso Nacional, por órgãos a ele vinculados, como o

${ }^{102}$ Mello, Celso Antonio Bandeira de, Curso de Direito Administrativo..., p. 36. 
Tribunal de Contas, ou pela atuação das Comissões Parlamentares de Inquérito (doravante poderá ser abreviado como CPIs), um dos objetos centrais desse estudo. ${ }^{103}$

Utilizamos aqui o termo controle de maneira genérica, englobando a função de fiscalização, que Canotilho trata de forma apartada. ${ }^{104}$ Também cabe esclarecer que a função de controle da qual se trata aqui não é a genérica decorrente da adoção do sistema de separação de poderes ou divisão de funções, mas sim a específica, que permite que um órgão controle a atuação de outro, podendo até mesmo impedir a prática de um determinado ato.

Ao controlarem, fiscalizarem e investigarem os assuntos relacionados a outros poderes, as CPIs não invadem sua atribuição, mas apenas exercem funções típicas da origem do Parlamento que revelam a idéia norteadora da teoria dos freios e contrapesos, a limitação do poder, e mais, proporciona uma nova forma de se aplicar a teoria da separação dos poderes como será visto no item sobre a interpenetração. ${ }^{105}$

Certos da relevância e complexidade do papel exercido pelas CPIs, deixamos para tratá-lo pormenorizadamente no capítulo dedicado exclusivamente a elas. Por ora, basta afirmar que se relacionam à função de controle específico e são exercidas pelo Poder Legislativo. Cabe, agora, tecer alguns comentários sobre outra função de destaque nesse estudo, a função jurisdicional.

\subsubsection{FUNÇÃO JURISDICIONAL}

A jurisdição é uma das expressões do poder e, como tal, seus objetivos se relacionam com os fins do próprio Estado. Sendo o bem-comum o fim último do Estado contemporâneo, a justiça é o escopo síntese da jurisdição. Todavia, podemos identificar

103 GonÇAlves, Luiz Carlos dos Santos, Poderes de Investigação das Comissões Parlamentares de Inquérito, São Paulo, Editora Juarez de Oliveira, 2001, p. 14-15.

${ }_{104}$ Canotilho, José Joaquim Gomes, Direito constitucional e teoria da constituição..., p. 638.

105 Gonçalves, Luiz Carlos dos Santos, Poderes de Investigação das Comissões Parlamentares de Inquérito..., p. 14-17. 
diversas vertentes desse escopo: a social é representada pela pacificação da sociedade; a política indica a afirmação da autoridade; e a jurídica, a atuação da vontade concreta do direito. $^{106}$

No viés jurídico, a jurisdição é o meio pelo qual o Estado busca a realização prática das normas em caso de conflito entre pessoas, declarando qual o preceito pertinente ao caso concreto e desenvolvendo medidas para que este seja realmente efetivado. Em suma, tem como finalidade assegurar a prevalência do direito positivo no país. ${ }^{107}$

Nos termos do que já foi exposto nos itens anteriores, um Estado de Direito implica a submissão dos órgãos estatais e dos cidadãos a normas jurídicas superiores. Todavia, como o descumprimento das regras sempre deve ser hipótese aventada, há que se prever um mecanismo de sanção ou mesmo de solução dos conflitos originados a partir da inobservância das normas. Em tais casos, possibilita-se a intervenção de juízes para restabelecer a ordem propugnada. Por isso, esse mecanismo de controle é essencial ao Estado Democrático de Direito. ${ }^{108}$

De forma mais objetiva, utilizando a classificação em razão dos atos jurisdicionais, a qual define a função jurisdicional como aquela que soluciona os conflitos de interesse em $\operatorname{casos} \operatorname{concretos}^{109}$, Celso Antonio Bandeira de Melo expõe que:

"Função jurisdicional é a função que o Estado, e somente ele, exerce por via de decisões que resolvem controvérsias com força de coisa julgada, atributo este que corresponde à decisão proferida em última instância pelo Judiciário e que é predicado desfrutado por qualquer sentença ou acórdão contra o qual não tenha havido tempestivo recurso. "110

\footnotetext{
${ }^{106}$ DinAMARCO, Cândido Rangel, A instrumentalidade do processo, $11^{\mathrm{a}}$ ed., São Paulo, Malheiros Editores, p. 387.

${ }^{107}$ CinTRA, Antonio Carlos de Araújo, Grinover, Ada Pellegrini e Dinamarco, Cândido Rangel, Teoria Geral do Processo, $17^{\mathrm{a}}$ ed., São Paulo, Malheiros Editores, 2001, p. 38.

${ }^{108}$ Afonso, Orlando Viegas Martins, Poder Judicial..., p. 19.

${ }^{109}$ CORTEZ, Luís Francisco Aguilar, Judiciário e Democracia.., p. 175.

${ }^{110}$ Mello, Celso Antonio Bandeira de, Curso de Direito Administrativo..., p. 36.
} 
No que concerne à definição legal, temos uma lacuna no texto constitucional brasileiro. O artigo 92 da Constituição Federal de 1988 relaciona os órgãos do Poder Judiciário sem detalhar o conteúdo de suas atribuições. Por sua vez, o artigo 127 do mesmo texto também menciona a função jurisdicional sem se referir a seu conteúdo. Apenas o inciso XXXV do artigo $5^{\circ}$ traz uma definição mínima do teor da função em apreço, que consiste na apreciação de lesões ou ameaças a direitos pelo Poder Judiciário. ${ }^{111}$ Sendo assim, a análise debruça-se sobre a doutrina acerca do tema.

Com efeito, o Poder Judicial, como órgão responsável pelo exercício da função ora analisada só terá efetivamente a configuração de um poder no caso de possuir a capacidade de impor suas decisões por seus próprios atos. Só assim poderá exercer o papel de último garante dos direitos fundamentais dos cidadãos, o qual lhe é conferido de forma exclusiva. $^{112}$

Para que essa função seja exercida adequadamente, são asseguradas algumas garantias aos juízes. Na verdade, estas nada mais são do que garantias ao povo de que a função jurisdicional será exercida da melhor maneira possível. Além disso, outras características lhe são essenciais para exercer sua tarefa de acordo com os ditames constitucionais. Em última instância, sempre se está a visar a realização da Justiça.

Outro ponto fulcral na análise das características essenciais da função jurisdicional diz respeito à legitimidade de seu exercício. Numa democracia, de forma geral, a legitimidade emana da escolha por meio de voto. No entanto, em alguns casos, a legitimação do poder advém da garantia de liberdade e respeito aos direitos fundamentais ínsitos ao Estado Democrático de Direito. Nesse sentido, Orlando Viegas Martins Afonso defende que

“...o poder judicial é a chave mestra da realização do Estado de Direito. O sistema normativo não se tornará efectivo se não for jurisdicionalmente sancionado e os

\footnotetext{
${ }^{111}$ SoUZA JUNIOR, Antonio Umberto de, Entre a primeira e a última palavras..., p. 88.

${ }^{112}$ Afonso, Orlando Viegas Martins, Poder Judicial..., p. 41-44.
} 
direitos fundamentais não estarão protegidos se não existir um juiz que assegure sua proteção. ",113

Assim, o juiz é investido no papel de "guardião de valores", garantindo os direitos fundamentais e regulando os conflitos sociais. Nos termos de Ángel Luis Alonso de Antonio e José Antonio Alonso de Antonio, os integrantes do Poder Judiciário são “los guardianes naturales e primeros de los derechos fundamentales y las libertades ciudadanas". 114

Para exercer tal função com isenção, o poder jurisdicional não pode extrair sua legitimidade da maioria. Seus interesses devem estar desvinculados dela, de modo a garantir a verdade das formulações judiciais e a liberdade dos cidadãos, única fonte fidedigna de legitimidade. ${ }^{115}$

Observe-se que tudo gira em torno de produzir decisões e soluções justas, o que implica a ausência de comprometimento com a sociedade ou consigo mesmo, isto é, deve haver isenção do julgador. Esta, por sua vez, é garantida por meio da imparcialidade, a qual está atrelada à independência do juiz. ${ }^{116}$

Segundo Orlando Viegas Martins Afonso, a isenção é atributo pessoal e relacionase com a inexistência de comprometimento prévio com valores pessoais ou da comunidade. Já a imparcialidade refere-se ao âmbito processual, isto é, não poderá haver comprometimento com as partes da relação processual. Por fim, a independência tem a ver com a separação de poderes no Estado de Direito, de modo a propiciar a atuação do Poder Judicial sem interferência dos demais. É por meio desta última que se garante a liberdade e a segurança dos cidadãos. ${ }^{117}$

\footnotetext{
${ }^{113}$ AFONSO, Orlando Viegas Martins, Poder Judicial..., p. 52.

${ }^{114}$ ANTONIO, Ángel Luis Alonso de e ANTONIO, José Antonio Alonso de, Derecho Constitucional Español, $4^{\mathrm{a}}$ Ed., Madrid, Editorial Universitas S.A., p. 504.

115 Afonso, Orlando Viegas Martins, Poder Judicial..., p. 50-61.

${ }^{116}$ Idem, p. 65-66.

${ }^{117}$ Idem, p. 67-72.
} 
A idéia de que o papel principal da magistratura é a proteção dos direitos fundamentais, uma vez que esta é a dimensão subjetiva do Estado Democrático de Direito, está presente em muitos autores. ${ }^{118}$ Não há dúvida de que a função jurisdicional é definida como aquela que soluciona os conflitos de interesses de forma definitiva, por meio da aplicação da lei. No entanto, é justamente no desempenho dessa tarefa, ao se buscar a solução mais justa para o caso concreto, que o juiz acaba por exercer o papel político e social de fiscalizar a observância da Constituição e garantir a efetivação dos direitos fundamentais. $^{119}$

Nesse sentido, é pertinente a transcrição do excerto de Luís Francisco Aguilar Cortez:

"A Constituição de 1988 valorizou a função jurisdicional, assim como ocorreu nos países com semelhantes sistemas constitucionais, outorgando-lhe não só aquela clássica atividade de 'composição de conflitos de interesse em cada caso concreto', mas também reforçando seu papel político social, como fiscal da Constituição e garante da efetivação dos direitos humanos. "120

Posto isto, cabe ressaltar, ainda, que o exercício dessa função jurisdicional, na seara da divisão de funções do Estado brasileiro, é exclusiva dos órgãos do Judiciário, de maneira que apenas ele tem competência para solucionar os conflitos e proteger os direitos fundamentais. Há, portanto, uma preservação da reserva de jurisdição no nosso

\footnotetext{
${ }^{118}$ Alguns autores fazem, também, o raciocínio inverso, asseverando que o desenvolvimento de um direito fundado essencialmente da teoria dos direitos fundamentais reforça a figura do juiz. Ver MATHIEU, Bertrand, VERPEAUX, Michel, Droit constitutionnel, Paris, Press Universitaires de France, 2004, p. 567.

119 Afonso, Orlando Viegas Martins, Poder Judicial..., p. 77; DAllari, Dalmo de Abreu, O Poder dos Juizes, $3^{a}$ Ed. rev., São Paulo, Editora Saraiva, 2007, p. 18; CORTEZ, Luís Francisco Aguilar, Judiciário e Democracia..., p. 177-179.

${ }^{120}$ CORTEZ, Luís Francisco Aguilar, Judiciário e Democracia..., p. 177.
} 
ordenamento jurídico. ${ }^{121}$ Esta premissa será essencial ao desenvolvimento do presente estudo.

\subsubsection{CONJUNTURA ATUAL: INTERPENETRAÇÃO DE PODERES E EXERCÍCIO DE FUNÇÕES TÍPICAS E ATÍPICAS ${ }^{122}$}

O ideal do Estado de Direito prevê que as funções administrativa, legislativa e jurisdicional devem ser exercidas por órgãos especializados e distintos. No entanto, a completa separação revelou-se impossível. ${ }^{123}$

Nos termos de Celso Antonio Bandeira de Mello, existe uma forte predominância em cada "Poder" da atividade que lhe é típica, mas não uma correspondência absoluta, existindo a possibilidade de exercerem atividades atípicas. Assim:

"tanto Legislativo, quanto Judiciário como Executivo exercem as três funções estatais: de modo normal e típico aquela que lhes corresponde primacialmente respectivamente, legislar, julgar e administrar - e, em caráter menos comum (ou

\footnotetext{
${ }^{121}$ CORTEZ, Luís Francisco Aguilar, Judiciário e Democracia..., p. 177. No ordenamento espanhol, utiliza-se a expressão exclusividad competencial para designar a noção de reserva de jurisdição, além de reserva de jurisdicción. Ver ANTONIO, Ángel Luis Alonso de e ANTONIO, José Antonio Alonso de, Derecho Constitucional Español..., p. 502. Já no idioma inglês houve maior dificuldade para identificar a expressão utilizada, pois parece não haver uma sistematização do instituto. Fala-se apenas na necessidade de judicial order em alguns casos. De qualquer maneira, diante da necessidade de se elaborar um resumo no idioma de proficiência, adotamos a expressão judicial reserve, também adotada no abstract da obra de Luiz Carlos dos Santos Gonçalves. Cf. GonÇAlves, Luiz Carlos dos Santos, Poderes de Investigação das Comissões Parlamentares de Inquérito, São Paulo, Editora Juarez de Oliveira, 2001.

${ }^{122}$ Conquanto as expressões típica e atípica possuam diversas acepções dentro do Direito, sobretudo no Direito Penal, esclarecemos que a terminologia foi adotada em virtude da classificação preconizada por Celso Antonio Bandeira de Mello, a qual pode ser conferida em sua obra Curso de Direito Administrativo..., p. 34.

${ }^{123}$ Caetano, Marcello, Manual de Direito Administrativo..., p. 13-14; ReIs, José Carlos Vasconcellos dos , Controle externo do Poder Judiciário..., p. 200; DALlARI, Dalmo de Abreu, Elementos de Teoria Geral do Estado..., p. 220; Russomano, Rosah, Curso de Direito Constitucional..., p. 140.
} 
até mesmo em certas situações muito invulgares, como ocorre no processo de impeachment), funções, em princípio, pertinentes a outros órgãos do Poder. "124

Nesse sentido, Canotilho esclarece que no âmbito da Constituição portuguesa também há menção expressa à interdependência dos órgãos de soberania, a qual possibilita a interpenetração de funções. Todavia, há um limite intransponível para esse intercâmbio de competências, que seria o núcleo essencial de cada uma das funções. ${ }^{125}$

Com efeito, cada função possui atividades que lhe são típicas e que só podem ser exercidas pelos respectivos órgãos de soberania, sob pena de se violar o princípio da separação. A idéia aqui é não se atribuir funções a um órgão a ponto de resultar no esvaziamento das funções materiais típicas de outro. Assim, só se admitem as exceções à correspondência entre órgãos e funções quando não se sacrificar seu núcleo essencial. ${ }^{126}$

O autor desenvolve a idéia de modelo de justiça ou justeza funcional. Segundo este, há que se investigar qual dos órgãos possui estrutura mais adequada a cumprir determinadas tarefas. ${ }^{127}$ Nesse sentido, pode-se afirmar que os órgãos especialmente qualificados para exercer determinadas funções não devem praticar os atos característicos das outras funções e pertinentes às competências dos demais órgãos. ${ }^{128}$

Antonio Umberto de Souza Junior utiliza interessante expressão para designar os casos em que os órgão exercem as funções típicas de outros. O autor fala em Impureza da Dinâmica Funcional, que pode apresentar zonas de baixa ou de alta turbulência, conforme a interferência for pequena ou grande. ${ }^{129}$

São elencadas como zonas de baixa turbulência: a atuação normativa dos tribunais por meio de regimentos internos e regulamentos; a atuação administrativa dos mesmos, ao

${ }^{124}$ Mello, Celso Antonio Bandeira de, Curso de Direito Administrativo..., p. 34. No mesmo sentido, Barroso, Luís Roberto, Comissões Parlamentares de Inquérito e suas Competências: Política, Direito e Devido Processo Legal, in Revista de Direito da Associação dos Procuradores do Novo Estado do Rio de Janeiro, 2000, p. 61.

${ }^{125}$ CANOTILHO, José Joaquim Gomes, Direito constitucional e teoria da constituição..., p. 551.

${ }^{126}$ Idem, p. 559.

${ }^{127}$ Idem , p. 552.

${ }^{128}$ Idem, p. 559.

${ }^{129}$ SOUZA JUNIOR, Antonio Umberto de, Entre a primeira e a última palavras..., p. 93. 
levar a cabo sua autogestão; a atuação jurisdicional do parlamento, quando julga crimes de responsabilidade; a atuação para-jurisdicional do Poder Legislativo ao efetuar a avaliação prévia de constitucionalidade; atuação do parlamento na composição de órgãos judiciais; e a atuação para-jurisdicional do governo ao providenciar a solução de conflitos no âmbito da Administração e ao cuidar da extensão subjetiva dos efeitos da coisa julgada. Essas situações devem ser encaradas com naturalidade, porquanto não representam sacrifício ao núcleo essencial de nenhuma função. ${ }^{130}$

Existem, entretanto, três situações consideradas de grande interferência entre os poderes, ou alta turbulência, que podem ensejar até mesmo a invasão do núcleo essencial das funções estatais e que, ao menos em tese, não devem ser admitidas. Elas ocorrem quando os tribunais atuam criando normas nas ações diretas de inconstitucionalidade e nos mandados de injunção; na atuação jurisdicional do Poder Executivo, ao aplicar algumas penalidades, ao fazer julgamentos como os efetuados pelo Conselho Administrativo de Defesa Econômica (CADE); e na atuação jurisdicional do Parlamento, quando o legislativo elabora uma lei para modificar os efeitos de uma decisão transitada em julgado, afrontando a reserva de jurisdição dos tribunais, ou mesmo quando edita anistias para extinguir os efeitos condenatórios de decisões penais. ${ }^{131}$

Um dos grandes problemas enfrentados na atualidade e não mencionado por Antonio Umberto, é a atuação normativa do Poder Executivo, o que se deve, em grande parte, à sua participação na elaboração de normas gerais e abstratas, haja vista a complexidade dos assuntos a serem regulados e a urgência em fazê-lo. No Brasil, isso se dá por meio da edição de Medidas Provisórias e, ainda que sejam editadas leis, a iniciativa delas não provém de um parlamentar, mas sim do chefe do Poder Executivo. ${ }^{132}$

Na vida moderna, há uma tendência de enfraquecimento da função legislativa do Poder Legislativo com o fortalecimento do Poder Executivo neste campo. ${ }^{133}$ Assim, e talvez seja essa a razão do silêncio de Antonio Umberto Souza Junior sobre este aspecto,

\footnotetext{
${ }^{130}$ SOUZA JUNIOR, Antonio Umberto de, Entre a primeira e a última palavras..., p. 98-101. ${ }^{131}$ Idem, p. 102-111.

132 Gonçalves, Luiz Carlos dos Santos, Poderes de Investigação das Comissões Parlamentares de Inquérito..., , p. 11-12.

${ }^{133}$ CASSEB, Paulo Adib, Controle governamental exercido pelo legislativo, in Repertório de Jurisprudência $I O B$, Vol. I, n. ${ }^{\circ} 01 / 2003$, p. 29.
} 
soa estranho apontar a função de normas pelo Executivo como atípica uma vez que, nos termos de Luiz Carlos dos Santos Gonçalves:

“...o fenômeno jurídico de um país regrado à medidas provisórias, como o nosso, já não teria a melhor explicação. Se virmos o tema sob o prisma do Executivo, o rol de suas funções típicas, predominantes, estaria em processo de acréscimo; sob o ponto de vista do Legislativo o rol das funções deste estaria em decréscimo."

Para o autor, o incremento da função parlamentar de controle e investigação propicia um rearranjo do esquema tradicional de supervalorização do Poder Executivo, na verdade, possibilita a retomada do equilíbrio das funções estatais. Note-se que mesmo o autor valorizando os poderes investigativos das CPIs, posição que contestaremos no Capítulo 6, ele assume que elas não possuem a capacidade de impor suas decisões, sendo meros instrumentos de coleta de informações. ${ }^{135}$

"As Comissões Parlamentares de Inquérito não podem invadir seara alheia e julgar ou impor a executoriedade de suas decisões. Ainda que nossa opinião seja prestigiadora dos poderes investigativos do Congresso, não há como ultrapassar o fato de que elas são apenas instrumentos de investigação, descoberta de fatos. Indiretamente, é certo, efeitos podem surgir dessa atividade. (...) Entretanto, a única finalidade direta que pode ser admitida sem controvérsia para as Comissões de Inquérito é política: fazem elas parte do 'jogo' democrático, são um poderoso

${ }^{134}$ GonçAlves, Luiz Carlos dos Santos, Poderes de Investigação das Comissões Parlamentares de Inquérito..., p. 13.

${ }^{135}$ Idem, p. 15-16. Paulo Adib Casseb também entende que, na conjuntura do Estado Social, onde a atividade administrativa foi incrementada, aumentou-se a atividade de controle e fiscalização por parte do Legislativo. Ver CASSEB, Paulo Adib, Controle governamental exercido pelo legislativo..., p. 29. 
instrumento deixado para o Parlamento ou suas minorias no concerto de suas relações com os demais poderes, em especial o Executivo. "136

Essa discussão é relevante para ilustrar a evolução do conteúdo de cada função. Todavia, não se pode deixar de esclarecer a relação entre a interpenetração de funções e o tema central desse estudo, qual seja, a reserva de jurisdição aplicada na investigação perpetrada pelas CPIs.

Com efeito, é inegável que a maior parte dos meios de prova e, sobretudo, dos meios de obtenção de prova resultam em invasões ou restrições aos direitos fundamentais dos indivíduos. ${ }^{137}$ Ora, sendo a proteção desses direitos função exclusiva do Poder Judiciário, pertencente a seu núcleo essencial, conforme expusemos no item 2.5.2.3, não se pode admitir que outro órgão estatal a exerça, ainda que a separação de poderes não possa ser encarada de forma absoluta num Estado Democrático de Direito. Isso porque, nos termos da teoria da justeza funcional, é o Poder Judiciário que tem a legitimidade, a independência, a isenção e a imparcialidade que lhe tornam o órgão mais adequado para cumprir esta tarefa de guardião de valores.

Dessa maneira, inadmissível estender às CPIs poderes de investigação e restrição a direitos fundamentais exclusivos da função jurisdicional.

Essa é a premissa da qual partiremos para desenvolver os próximos capítulos, nos quais serão revelados outros fundamentos da existência da reserva de jurisdição no ordenamento brasileiro, bem como em quais situações se aplica no Processo Penal para,

${ }^{136}$ GonçAlves, Luiz Carlos dos Santos, Poderes de Investigação das Comissões Parlamentares de Inquérito..., p. 16.

${ }_{137}$ Meios de prova são coisas ou pessoas que levam informações ou percepções ao julgador no bojo de um processo, enquanto que meios de obtenção de prova são os instrumentos que captam essas coisas ou pessoas. Cf. PACHECo, Denilson Feitoza, Direito processual penal: teoria, crítica e práxis, $5^{\mathrm{a}}$ Ed. rev. e atual. com Emenda Constitucional da Reforma do Judiciário, Niterói, Impetus, 2008, p. 604-605. Mais detalhes sobre a natureza e o conceito no item 4.2. Exatamente pela natureza invasiva dos meios de investigação, e os conseqüentes atentados aos direitos fundamentais é que se revela sua maior ligação com as hipóteses de reserva de jurisdição. Mas isso não significa que não existam meios de prova que também tenham o condão de violar direitos individuais. Exemplo é a prova documental derivada de cópia de procedimento administrativo tributário cujo conteúdo é acobertado pelo sigilo fiscal, o que está explicado de forma pormenorizada no item 4.2 . 
então, delimitarmos a exata extensão dos poderes investigatórios das CPIs, sem que haja a combatida invasão ao núcleo essencial da função jurisdicional que enseja, em última instância, violação aos direitos fundamentais dos cidadãos. 


\section{RESERVA DE JURISDIÇÃO}

O capítulo anterior foi dedicado à exposição da estrutura de um Estado Democrático de Direito, dando especial atenção à separação dos poderes e ao exercício das funções atribuídas a cada um deles. No último item, dedicado a desmistificar a divisão ferrenha das tarefas, demonstramos a possibilidade de interpenetração dos poderes, desde que seja respeitado o núcleo essencial da função em questão. Ainda, expusemos a idéia de Canotilho acerca do modelo de justeza funcional, segundo o qual deve existir um determinado órgão cuja estrutura seja mais adequada ao exercício de uma certa função. ${ }^{138}$

Essas duas noções, de núcleo essencial da função e de modelo de justeza funcional, são fundamentais para o desenvolvimento do presente trabalho. Isso porque nossa intenção é estabelecer os casos em que apenas o órgão adequado, qual seja, o Judiciário, pode exercer sua função típica, a jurisdicional. A idéia é que outros órgãos, que não tenham estrutura adequada, só podem perpetrar invasões na esfera da função jurisdicional na medida em que seu núcleo essencial não for atingido.

Nesse sentido, nossa missão é discorrer sobre a reserva de jurisdição, isto é, sobre os casos em que a função jurisdicional só pode ser exercida pelos órgãos pertencentes ao Poder Judiciário, estabelecendo sua definição e a maneira pela qual são fixadas as hipóteses em que ela existe, sobretudo na seara dos meios de obtenção de prova, pois, ao final, as conclusões serão relacionadas com a atuação das Comissões Parlamentares de Inquérito.

Foi consolidado que a função jurisdicional pode ser desempenhada por outros órgãos em algumas situações específicas. No entanto, há casos em que nenhum deles poderá se imiscuir no exercício dessa função judicante, a qual só poderá ser levada a cabo pelo órgão melhor estruturado para tanto. Percebe-se aí a presença das duas idéias destacadas anteriormente: nenhum outro órgão poderá interferir naquilo que for considerado como núcleo essencial da função jurisdicional, para que não haja o que se

${ }^{138}$ CANOTILHo, José Joaquim Gomes, Direito constitucional e teoria da constituição..., p. 552. 
chamou de esvaziamento de suas funções materiais; e, nesses casos, ela deverá ser exercida pelo Poder Judiciário, órgão cujas características permitem uma melhor atuação. ${ }^{139}$

A fixação de uma reserva como essa, portanto, presta para ligar a dimensão organizatória à dimensão material das funções do Estado, ou seja, para estabelecer que a prática de certos atos (sobretudo aqueles que ensejam restrições de direitos fundamentais como se verá adiante) só possa ser feita por um órgão detentor de características que o tornem mais adequado para tanto. Com isso, busca-se atingir um equilíbrio político, razão pela qual Paulo Castro Rangel afirma que "a reserva é o novo nome da separação dos poderes". ${ }^{140}$ Bastante elucidativa é a transcrição de um trecho da obra do autor:

"Ora, com o estabelecimento de uma reserva pretende justamente garantir-se que o órgão político-constitucionalmente pensado para se desincumbir de uma certa função, o faça efectivamente (e sem interferência de outro órgão). Trata-se, pois, de uma técnica normativa destinada a revigorar a idéia de separação dos poderes $e$ onde, melhor do que em quaisquer outras, se verifica o fenômeno da contaminação material das normas organizatórias, por isso que se liga incidivelmente o domínio de uma matéria determinada à estruturação de um certo órgão. "141

\footnotetext{
${ }^{139}$ No item 2.5.3. destacamos que o limite intransponível para a interpenetração entre os poderes é o núcleo essencial de cada função, especialmente em seu aspecto material, o qual se relaciona com a causa ou o resultado da atividade. Observe-se, oportunamente, que a definição acerca de quem exerce determinada função tem a ver com seu aspecto orgânico.

140 Rangel, Paulo Castro, Reserva de Jurisdição, sentido dogmático e sentido jurisprudencial, Porto, Universidade Católica Editora, 1997, p. 27.

${ }^{141}$ Rangel, Paulo Castro, Reserva de Jurisdição..., p. 27. No mesmo sentido, e aprofundando a idéia de justeza funcional, Ángel Luis Alonso de Antonio e José Antonio Alonso de Antonio "Resulta lógico qui si hay um poder judicial diferenciado, sólo a esse poder corresponda el conocimiento y decisión de los litigios. Serán por tanto jueces y tribunales los únicos a los que El Estado reconoce legitimación para resolver aquellas controvérsias que lejos de dilucidarse recurriendo a la fuerza física, debe tener como parâmetro de decisión médios pacificos a través Del Derecho, aplicado precisamente por el juez." Cf. Derecho Constitucional Español..., p. 502.
} 
O tema é pouco explorado pela doutrina nacional e internacional, o que é, inclusive, admitido por Paulo Castro Rangel, autor português que dedicou monografia ao tema. ${ }^{142}$ No entanto, as premissas das quais decorre a reserva de jurisdição são objeto de grande produção acadêmica, de maneira que nosso trabalho será compilar algumas idéias para demonstrar sua origem e justificar sua existência. Devemos destacar, ainda, a imperiosidade da aplicação dessa relevante garantia dos direitos individuais, consistente na exigência de uma decisão judicial para lhes aplicar qualquer restrição.

\subsection{RESERVA RELATIVA E ABSOLUTA}

Segundo Canotilho, a rejeição constitucional à justiça privada, isto é, buscar a concretude de seus direitos com "as próprias mãos", implica a existência de órgãos imparciais e qualificados que se proponham a solucionar conflitos mediante a aplicação da lei aos casos concretos. Para tanto, tais órgãos devem ter o monopólio da jurisdição, "pois isso é uma dimensão ineliminável do princípio do Estado de Direito e um corolário material do princípio da divisão de poderes". ${ }^{143}$

O autor esclarece que a doutrina distingue dois tipos de monopólio, o da primeira e o da última palavra. Paulo Castro Rangel, por sua vez, fala em critério das duas palavras para se referir aos dois níveis de reserva de jurisdição, dividindo o instituto em absoluto e relativo. É possível traçar um paralelo entre as duas classificações, de modo que as apresentaremos de forma concomitante. ${ }^{144}$

O monopólio da última palavra consiste no direito de qualquer indivíduo ter acesso a processo justo para a defesa de suas posições jurídico-subjetivas, que pode ser exercido tanto em face de atos estatais, quanto nos casos em que houver litígios entre particulares. ${ }^{145}$ Paulo Castro Rangel denomina esta situação de reserva de jurisdição relativa e esclarece

\footnotetext{
${ }^{142}$ RANGel, Paulo Castro, Reserva de Jurisdição..., p. 27.

${ }^{143}$ CANotillo, José Joaquim Gomes, Direito constitucional e teoria da constituição..., p. 667.

144 CANotilho, José Joaquim Gomes, Direito constitucional e teoria da constituição..., p. 668; RANGEL, Paulo Castro, Reserva de Jurisdição..., p. 61.

${ }^{145}$ Canotilho, José Joaquim Gomes, Direito constitucional e teoria da constituição..., p. 668.
} 
que nesses casos são admitidas intervenções de outras autoridades, desde que estas sejam, ao final, passíveis de controle judicial. ${ }^{146}$

Muitos autores equiparam essa figura à garantia da inafastabilidade do controle jurisdicional que, no ordenamento brasileiro, está consolidada no inciso XXXV do artigo $5^{\circ}$ da Constituição Federal. Isso porque ela assegura, se necessária, a intervenção do Judiciário, o qual proporcionará uma tutela jurisdicional. ${ }^{147}$ Paulo Castro Rangel discorda da denominação de mera garantia de acesso ao Judiciário, insistindo na qualificação de reserva, por acreditar que, mesmo quando o tribunal se limita a proferir a última decisão, está a exercer uma função materialmente jurisdicional, constitucionalmente reservada a ele, que não pode ser atribuída a nenhuma outra autoridade. ${ }^{148}$

Para ele, ainda, o critério definidor da reserva relativa é a presença de um interesse público de viés administrativo que legitime a intervenção decisória de autoridade não jurisdicional para a solução da questão jurídica que se apresenta. Seriam casos estritamente relacionados ao desenvolvimento das atividades da administração pública. ${ }^{149}$ Esse não é o melhor entendimento segundo nossa visão e discordaremos do autor neste ponto, apesar de adotar sua teoria na maior parte do presente estudo.

Diferente é a situação em que observamos a reserva de jurisdição absoluta ${ }^{150}$, ou monopólio da primeira palavra. ${ }^{151}$ Neste caso, compete ao juiz não apenas a última palavra na definição do direito aplicável aos conflitos de interesses, mas também a primeira, impedindo qualquer intervenção de outra autoridade. Para Paulo Castro Rangel, as matérias que se submetem a esse regime dividem-se em diversas categorias: aquelas previstas em preceitos da Constituição, consistentes na reserva absoluta especificada de jurisdição; aquelas, também especificadas, cuja origem deriva de lei ordinária; e a

\footnotetext{
${ }^{146}$ RANGEL, Paulo Castro, Reserva de Jurisdição..., p. 65.

${ }^{147}$ Exemplos são Franco, Alberto Silva e Moraes, Maurício Zanoide de, Cap. I - Devido Processo Legal, in FRANCO, Alberto Silva e STOCO, Rui (coord.), Código de processo penal e sua interceptação jurisprudencial, vol. I, $2^{\text {a }}$ ed. rev. atual. e ampl., São Paulo, Ed. Revista dos Tribunais, 2004, p. 332. Os autores observam que o "monopólio da última palavra" decorre do princípio da separação dos poderes, em virtude do qual o Poder Judiciário é o responsável pela garantia de justiça. Cf. Idem.

${ }^{148}$ RANGEL, Paulo Castro, Reserva de Jurisdição..., p. 65.

${ }^{149}$ Idem, p. 64.

${ }^{150}$ Idem, p. 63.

${ }^{151}$ CANOTILHo, José Joaquim Gomes, Direito constitucional e teoria da constituição..., p. 669.
} 
categoria incerta de atos materialmente jurisdicionais, desde que não haja interesse público que enseje uma intervenção administrativa prévia no caso. ${ }^{152}$

Já para Canotilho, o monopólio da primeira palavra será imperioso nos casos em que “...estão em causa direitos de particular importância jurídico-constitucional a cuja lesão deve corresponder uma efectiva proteção jurídica." ${ }^{\prime 53}$ Observe-se que Paulo Castro Rangel acaba por inverter um pouco o raciocínio muito difundido entre nós desenvolvido por Canotilho que dá um tom de especialidade às situações submetidas à reserva absoluta de jurisdição que envolveriam o chamado interesse público primário, notadamente, acarretam algum tipo de risco aos direitos fundamentais dos indivíduos pertencentes à coletividade.

No entendimento de Paulo Castro Rangel, a nota diferenciadora entre os níveis de reserva estaria situada na presença de um interesse público externo ao conflito a ser solucionado, interesse este que legitima a intervenção inicial de uma autoridade não jurisdicional. Perceba-se que o autor trata do interesse do governo, da máquina administrativa, e entende que nos casos em que é necessário um pronunciamento dessas autoridades por se tratar de matéria que exige decisão política, haverá a reserva relativa de jurisdição. $^{154}$

Temos, portanto, duas observações a fazer. A primeira é que neste ponto o raciocínio de Paulo Castro Rangel inverte a ordem das premissas. Na verdade, não é o interesse da administração que torna a reserva relativa. A reserva existe por conta da possibilidade de ocorrer um conflito de interesses, qualquer que seja sua natureza, e ser necessário o pronunciamento judicial para a solução definitiva da questão jurídica, de aplicação do direito. Em outras palavras, a reserva implica a existência de um ato materialmente jurisdicional. E ela será relativa porque o interesse envolvido não tem magnitude suficiente para impedir a intervenção de autoridades não judiciárias. O interesse a que o autor refere-se é o que a doutrina administrativista chama de interesse público secundário e, no nosso entender, apenas o interesse público primário tem o condão de tornar a reserva de jurisdição absoluta, uma vez que o valor máximo de uma sociedade

\footnotetext{
${ }^{152}$ RANGEL, Paulo Castro, Reserva de Jurisdição..., , p. 63-64.

${ }_{153}^{15}$ CANotillo, José Joaquim Gomes, Direito constitucional e teoria da constituição..., p. 669;

${ }^{154}$ RANGEL, Paulo Castro, Reserva de Jurisdição..., p. 64.
} 
situa-se nos indivíduos que a compõe e apenas o risco de violação de seus direitos fundamentais é que justifica a atuação do Poder Judiciário como seu único guardião. ${ }^{155}$

Além disso, como bem pontua Canotilho, o monopólio da última palavra não existe apenas nos casos em que o conflito dirige-se a atos do Estado. Também existem casos de litígios jurídico-privados que carecem de decisão definitiva e imparcial, nos quais não observaríamos a necessidade de prévia atuação governamental. ${ }^{156}$ Pode até ser que um órgão do Poder Executivo atue na tentativa de solução do conflito, mas não observaríamos o envolvimento de assuntos do governo como parece exigir Paulo Castro Rangel.

\subsubsection{DEFINIÇÃO DO CONTEÚDO DOS NÍVEIS DE RESERVA}

Nos parágrafos anteriores foram dados importantes passos rumo à eleição do critério que servirá à definição dos casos que devem se submeter à reserva de jurisdição. Segundo Paulo Castro Rangel, reserva relativa de jurisdição ou monopólio da última palavra implica o exercício de atos materialmente jurisdicionais, os quais se consubstanciam na resolução de um conflito de interesses num caso concreto, de acordo com cânones ou critérios normativos jurídicos com o único fim de solucionar tal celeuma. ${ }^{157}$ Até aí, estamos de acordo com diversas definições sobre a função jurisdicional mencionadas em item anterior (2.5.2.3), como a de Cintra, Grinover e Dinamarco ${ }^{158}$ e Luís Francisco Aguilar Cortez ${ }^{159}$.

\footnotetext{
${ }^{155}$ Para Celso Antonio Bandeira de Mello, interesse público primário refere-se ao "plexo dos interesses dos indivíduos enquanto partícipes da sociedade" correspondendo à "dimensão pública dos interesses individuais" enquanto que interesse público secundário são os interesses particulares do próprio Estado. Ver Mello, Celso Antonio Bandeira de, Curso de Direito Administrativo..., , p. 65.

${ }^{156}$ CANOTILHo, José Joaquim Gomes, Direito constitucional e teoria da constituição..., p. 668.

157 A definição de ato materialmente jurisdicional é dada por Paulo Castro Rangel, respaldado na jurisprudência do Tribunal Constitucional Português. São dadas como exemplos decisões sobre custas judiciais e sobre indenização por danos causados por embarcações. Ver RANGEL, Paulo Castro, Reserva de Jurisdição..., p. 40 e 64.

${ }_{158}$ CinTrA, Antonio Carlos de Araújo, Grinover, Ada Pellegrini e Dinamarco, Cândido Rangel, Teoria Geral do Processo..., p. 38.

${ }^{159}$ CORTEZ, Luís Francisco Aguilar, Judiciário e Democracia...: p. 175.
} 
Esta caracterização é importante, mas não se pode deixar de acrescentar à função de resolução dos conflitos mediante a aplicação do direito, um atributo mencionado por Celso Bandeira de Mello no trecho transcrito acima (item 2.5.2.3), o da coisa julgada, em razão do qual a questão objeto da controvérsia acaba sendo solucionada de maneira definitiva. ${ }^{160}$ Esta é a grande peculiaridade da função jurisdicional que torna a denominação reserva relativa mais adequada do que a expressão garantia de inafastabilidade do Judiciário.

Com efeito, sabemos que a função administrativa também trabalha com a idéia de aplicação do direito para atingir o bem comum. Todavia, só a jurisdição permite a resolução de conflitos de interesses de forma peremptória. Assim, ao discordar da denominação de garantia de acesso ao Judiciário para os casos que, em um primeiro momento, podem ser objeto de simples pronunciamento administrativo e, ao pugnar pela utilização da expressão reserva relativa de jurisdição, Paulo Castro Rangel pretende destacar a idéia de definitividade do pronunciamento judicial, bem como da prática de ato materialmente jurisdicional. ${ }^{161}$

Nesse sentido, temos o trecho de Candido Rangel Dinamarco:

"Das funções realizadas pelo Estado é a jurisdição a única dotada do predicado de definitividade, caracterizado pela imunização dos efeitos dos atos realizados. (...) Os atos dos demais Poderes do Estado podem ser revistos pelos juízes no exercício da jurisdição, mas o contrário é absolutamente inadmissível." 162

Sendo o ato materialmente jurisdicional o critério definidor da reserva de jurisdição relativa, isto é, considerando que o Judiciário terá o monopólio da última palavra nos casos em que o conflito de interesses tiver de ser resolvido por meio da aplicação do direito de maneira definitiva, resta-nos delimitar os casos em que a reserva de jurisdição será

\footnotetext{
${ }^{160}$ Mello, Celso Antonio Bandeira de, Curso de Direito Administrativo..., p. 36.

${ }^{161}$ RANGEL, Paulo Castro, Reserva de Jurisdição..., p. 63-64.

162 Dinamarco, Candido Rangel, Instituições de Direito Processual Civil, V. I, $1^{\text {a }}$ Ed., São Paulo, Malheiros Editores, 2002, p. 313-314.
} 
absoluta, ou seja, quando o Judiciário terá o monopólio da primeira palavra e apenas ele poderá se manifestar num determinado caso. Estamos buscando, portanto, a demarcação do núcleo essencial da função jurisdicional, onde só o Poder Judiciário poderá intervir.

Para tanto, imaginemos um grande círculo, no qual estão inseridos todos os casos em que há exercício da função materialmente jurisdicional, de resolução de conflitos de interesses de forma definitiva mediante a aplicação da lei. Dentro dele, existe uma pequena parcela de conflitos nos quais há um interesse público primário envolvido ${ }^{163}$, que justifica o tratamento excepcional do caso, permitindo-se apenas a manifestação do Poder Judiciário. $^{164}$

Reserva absoluta de jurisdição é, portanto, a situação de conflito de interesses que exige a atuação do Poder Judiciário de forma exclusiva, porquanto sua resolução, além de envolver um ato materialmente jurisdicional, isto é, aplicação de normas para solução de controvérsia de forma definitiva, envolve risco de violação a bem constitucionalmente relevante, relacionado ao interesse público primário. Abstratamente, a questão parece solucionada, mas há que se perquirir quais são esses casos nos quais há direitos que exigem grande proteção jurídica.

\subsubsection{HIPÓTESES DE APLICAÇÃO DA RESERVA ABSOLUTA}

A questão atinente ao âmbito de aplicação da reserva de jurisdição absoluta é controversa. É indubitável seu emprego nos casos a ela submetidos por meio de preceitos constitucionais. ${ }^{165}$ No direito pátrio, temos o exemplo da interceptação telefônica, expressamente submetida ao monopólio da primeira palavra em virtude do disposto na ressalva do inciso XII do artigo $5^{\circ}$ da Constituição. Paulo Castro Rangel batiza a

\footnotetext{
${ }^{163}$ Para definição de interesse público primário, ver nota 155. Mello, Celso Antonio Bandeira de, Curso de Direito Administrativo..., p. 65.

${ }^{164}$ Canotilno, José Joaquim Gomes, Direito constitucional e teoria da constituição..., p. 669; RANGel, Paulo Castro, Reserva de Jurisdição..., p. 63-64.

${ }^{165}$ CANOTILHO, José Joaquim Gomes, Direito constitucional e teoria da constituição..., p. 669.
} 
circunstância de reserva absoluta especificada de jurisdição de origem constitucional, conforme já pontuamos. ${ }^{166}$

Ademais, complementa o autor, "Fora desse domínio, poderá ainda haver uma reserva absoluta de jurisdição especificada, mas de origem ou criação legal". ${ }^{167}$ Isso significa que ao lado da chamada reserva de juiz constitucional, culminada em texto supremo, admite-se a reserva legal de juiz, prevista em lei ordinária. Tal avanço está fundado na concepção material de jurisdição, o que se coaduna com o posicionamento do autor relativo à aplicação da reserva de jurisdição mesmo quando não há qualquer tipo de previsão no ordenamento. ${ }^{168}$

Nessa esteira, Canotilho afirma que mesmo se a reserva não é feita expressamente, pode-se entender que ela existe se as circunstâncias do conflito de direitos levam a tal conclusão, in verbis:

"Fora os casos individualizados na Constituição, o reconhecimento do monopólio da primeira palavra tende a afirmar-se quando não existe qualquer razão ou fundamento material para a opção por um procedimento não judicial de decisão de litígios. É este o caso quando estão em causa direitos de particular importância jurídico-constitucional a cuja lesão deve corresponder uma efetiva proteção jurídica". 169

Do exposto, depreendemos que a reserva jurisdicional positivada, seja ela constitucional ou legal, apresenta a facilidade de por fim às indagações acerca da necessidade de decisão judicial inicial. Todavia, não soluciona a principal dúvida concernente ao tema deste estudo: por que, em determinadas situações, a decisão judicial é

\footnotetext{
${ }^{166}$ RANGEL, Paulo Castro, Reserva de Jurisdição..., p. 63. Diz o autor: "Não restam dividas de que o juiz terá a primeira e a última palavra naquele conjunto de situações especificamente previstas em preceitos de Constituição e que formam aquilo a que chamamos uma reserva absoluta especificada de jurisdição."

${ }^{167}$ Idem, p. 63.

${ }^{168}$ Canotilho, José Joaquim Gomes, Direito constitucional e teoria da constituição..., p. 669; RANGel, Paulo Castro, Reserva de Jurisdição..., p. 64.

${ }^{169}$ CANOTILHO, José Joaquim Gomes, Direito constitucional e teoria da constituição..., p. 669.
} 
fulcral para a solução do celeuma, sendo necessária e indispensável desde o primeiro pronunciamento sobre o caso? Note-se, a questão é antecedente à positivação da reserva e diz respeito ao motivo pelo qual o constituinte ou legislador decide que um conflito de direitos ou interesses exige pronunciamento de um tribunal para ser solucionado e outro não.

Observe-se que, se obtivermos sucesso na resposta dessa dúvida, não estaremos apenas encontrando os motivos pelos quais as cláusulas de reserva foram inseridas nos textos legais, mas também e, principalmente, teremos o ponto de partida para estender essa regra a todos os casos semelhantes, de maneira a estabelecer um critério sobre reserva de jurisdição universal e independente de previsão legal expressa.

Se iniciarmos a empreitada com base no raciocínio de Canotilho sobre os casos de reserva não explícita, chegaremos à conclusão de que o ponto central refere-se à natureza dos direitos conflitantes, que devem possuir grande relevância jurídica e constitucional. Vale dizer, o juiz deverá se manifestar sempre que houver a ameaça ou violação de um direito fundamental ou bem jurídico constitucionalmente protegido, nos termos da moderna teoria de resolução de conflitos, que pugna pela aplicação do postulado da proporcionalidade.

Então surge outra pergunta: por que o juiz é quem deve tomar essa decisão, e não outro órgão? É o que pretendemos responder com base no Estado Democrático de Direito, na divisão de poderes e nas três características essenciais do Poder Judiciário, a isenção, a imparcialidade e a independência.

Por fim, trataremos brevemente sobre outro princípio decorrente da estrutura do Estado Democrático de Direito, o devido processo legal, que reforça a idéia de que apenas com ordem judicial é possível promover a restrição a qualquer direito fundamental de um indivíduo, já que funciona como "cláusula de segurança” para um processo justo. ${ }^{170}$

\footnotetext{
${ }^{170}$ FranCo, Alberto Silva e MoraES, Maurício Zanoide de, Cap. I - Devido Processo Legal..., , p. 252 e 332.
} 


\subsection{FATORES JUSTIFICANTES DA CLÁUSULA DE RESERVA DE JURISDIÇÃO}

Como dito acima, pretendemos explorar todas as facetas da reserva de jurisdição, explicando não apenas porque é necessária a intervenção do juiz quando houver necessidade de restrição de um direito fundamental, mas também porque este é o órgão mais adequado, apresentando sua relação com o princípio do devido processo legal.

Com a intenção de inserir esses itens em uma mesma categoria, optamos por denominá-los de fatores justificantes, entendendo ser uma expressão que engloba as três situações que serão apresentadas.

\subsubsection{A ESSÊNCIA DA FUNÇÃO JURISDICIONAL E SEUS ATRIBUTOS - INDEPENDÊNCIA, IMPARCIALIDADE E ISENÇÃO}

Vimos no desenvolvimento do tema acerca da elaboração da teoria da separação dos poderes por Montesquieu, que o Poder Judiciário era visto como mera boca da lei, isto é, o papel do juiz era apenas aplicar a norma ao caso concreto, sendo-lhe vedada qualquer manobra interpretativa.

Nesse sentido, Paulo Castro Rangel constrói um paralelo entre reserva de jurisdição e reserva de lei, afirmando que aquela, entendida como o exercício exclusivo da função jurisdicional pelos tribunais, surgiu para assegurar esta, impedindo que a administração interviesse em certos domínios, sobretudo os referentes aos direitos fundamentais. Ao dar consecução à subsunção da norma ao fato, o juiz exercia o papel de "longa manus" do Parlamento. Por tal motivo, o autor assevera que "o sentido de reserva de jurisdição 
exauria-se nesse carácter essencialmente instrumental ante o princípio da reserva de lei." $" 171$

Ora, sabemos que o Direito é muito mais do que o mero texto legal ${ }^{172}$, de maneira que a atividade judicante não pode se restringir a aplicar a vontade do legislador. Prova disso é a possibilidade do magistrado avaliar a validade da própria lei. ${ }^{173}$ Desta forma, o conceito de reserva de jurisdição evoluiu, de maneira a entender-se, atualmente, que:

\begin{abstract}
“o espaço material da reserva de jurisdição já não coincide necessariamente com a da reserva da lei, e, portanto, que a reserva de jurisdição não é mais um simples instrumento ou garantia da reserva de lei. Na verdade, ao solucionar os conflitos que se lhe deparam, ao resolver os casos da vida, o tribunal pode ser chamado-e, porventura, sê-lo-á sempre, atento o imperativo da unidade do sistema jurídico - a actuar critérios normativos que estão fora da mão do legislador e a controla a conformidade das disposições legislativas a tais critérios. "174
\end{abstract}

Afere-se do trecho transcrito que a configuração do Poder Judiciário mudou, assumindo um papel independente, não apenas do Poder Legislativo, mas também do Executivo. Observe-se que a idéia de que a independência deriva do Estado de Direito está mantida, da mesma forma que ocorria na concepção original da teoria da separação dos poderes. Alterou-se, entretanto, seu significado, dando especial destaque à necessidade do Poder Judicial atuar em defesa dos direitos do homem, expressão do interesse público

\footnotetext{
${ }^{171}$ RANGEL, Paulo Castro, Reserva de Jurisdição..., p. 12-15.

${ }^{172}$ Eros Roberto Grau dedica-se a revelar a abrangência do direito. Não convém transcrever aqui todas as passagens nas quais o autor apresenta seu entendimento acerca do tema. Basta uma para confirmar nossa premissa: "A visão do direito apenas como norma, no entanto, é parcial e incompleta. Nomos, tal qual Lawcomo observa ainda Carl Schmitt (1972/254) -, não significa lei, regra ou norma, mas direito, que é tanto norma, quanto decisão, quanto, sobretudo, ordenamento." Ver GRAU, Eros Roberto, $O$ direito posto e o direito pressuposto, $5^{\mathrm{a}}$ Ed. ver e ampl., São Paulo, Editora Malheiros, 2003, p. 19.

${ }^{173}$ RANGEL, Paulo Castro, Reserva de Jurisdição..., p. 20.

${ }^{174}$ Idem, p. 21-22.
} 
primário, no momento em que atua para solucionar os conflitos que lhe são apresentados. $^{175}$

Canotilho afirma que a existência de um Poder Judiciário como órgão separado dos demais deriva da necessidade de garantir a liberdade, uma vez que não é possível o usufruto desse direito quando há confusão entre quem faz as leis, quem as aplica e quem julga, bem como de garantir a independência da magistratura. ${ }^{176}$

Nessa esteira, os sistemas constitucionais em geral prevêem alguns mecanismos para preservar o Estado Democrático de Direito e os juízes destacam-se como a principal maneira de se proteger os direitos das pessoas e da sociedade, exatamente por sua atuação autônoma. ${ }^{177}$ Alberto Silva Franco e Maurício Zanoide de Moraes compartilham desse entendimento:

"Nesse sentido, repousa a idéia elementar contida no princípio da 'reserva de jurisdição': diante de um Estado Democrático de Direito no qual vige o princípio da Separação de Poderes e no qual se delega ao Poder Judiciário a decisão sobre conflitos ou controvérsias sobre a norma aplicável ao caso concreto, define-se que sempre está reservado ao Poder Judiciário, e somente a ele, dizer o direito, notadamente na defesa dos direitos e garantias fundamentais do cidadão., 178

\footnotetext{
${ }^{175}$ Orlando Viegas Martins Afonso aborda em tópicos diferentes a independência do Poder Judicial na teoria da separação dos poderes, e a independência do Poder Judicial na concepção do Estado de Direito. No primeiro caso, embora a distinção das funções já seja vista como uma forma de garantir a liberdade dos indivíduos, são observados mecanismos que inibem o juiz de ultrapassar seu dever de aplicar a lei, impedindo-o de utilizar uma criatividade excessiva. Com a emergência do Estado de Direito como instrumento de defesa dos direitos humanos, sempre se submetendo ao direito, sua independência assume significado diverso, ultrapassando a aplicação passiva da lei e autorizando certa criatividade jurisprudencial. Ver, AfONSO, Orlando Viegas Martins, Poder Judicial..., p. 72-79. Cf. também MACHADO, Santiago Muñoz, La reserva de jurisdicción, Madrid, La Ley, 1989, p. 116.

${ }_{177}^{176}$ CANOTILHO, José Joaquim Gomes, Direito constitucional e teoria da constituição..., p. 658.

${ }^{177}$ ANTONIO, Ángel Luis Alonso de e ANTONIO, José Antonio Alonso de, Derecho Constitucional Español..., p. 496.

${ }^{178}$ Franco, Alberto Silva e MORAES, Maurício Zanoide de, Cap. I - Devido Processo Legal..., p. 332.
} 
Orlando Viegas Martins Afonso aponta uma interessante divisão dos planos de atuação do Poder Judicial, que ajuda a entender esse papel de guardião dos valores fundamentais. ${ }^{179} \mathrm{O}$ primeiro deles relaciona-se com a necessidade de subordinação da lei à Constituição no Estado de Direito ${ }^{180}$, o que exige a intervenção de um juiz para fazer valer a hierarquia normativa estabelecida; o segundo refere-se ao controle jurisdicional sobre a submissão da administração às normas que delineiam sua atividade; o terceiro e último tem a ver com a acepção substancial do Estado de Direito, a qual exige um juiz para atuar como garante dos direitos fundamentais. Por tudo isso é que o autor afirma que "no Estado de Direito, a existência de um poder judicial independente e imparcial é uma exigência estrutural do Estado". ${ }^{181}$

Tendo sido assinalada a relevância da independência do Poder Judiciário para a defesa da liberdade e proteção dos direitos fundamentais, bem como a alteração de seu papel de um mero aplicador da lei para um órgão que tenha o condão de criar e interpretar as normas da forma mais conforme com o texto supremo ao resolver os conflitos de interesses ${ }^{182}$, cumpre tecer algumas considerações sobre a legitimação do Poder Judicial para o exercício dessas funções, que reforça a necessidade de sua autonomia.

\footnotetext{
${ }^{179}$ AfONSO, Orlando Viegas Martins, Poder Judicial..., p. 77-78.

${ }^{180}$ Para Canotilho, esta faceta da independência é denominada de independência funcional. Cf. CANOTILHO, José Joaquim Gomes, Direito constitucional e teoria da constituição..., p. 664.

${ }^{181}$ A acepção substancial do Estado de Direito relaciona-se com seu conteúdo, cujo núcleo é constituído pelo conjunto de direitos fundamentais consagrados no plano constitucional. Ver AFONSO, Orlando Viegas Martins, Poder Judicial..., p. 77-78.

182 É sabido que os textos normativos apresentam diversos significados, de modo que a atividade interpretativa consiste em escolher um desses significados. Segundo o princípio da interpretação conforme a Constituição, devemos escolher o significado que mais se coadunar com o texto supremo. Não se trata apenas de tentar "salvar" a norma de uma eventual declaração de inconstitucionalidade, como nos ensina Canotilho: "Ora, o princípio da interpretação conforme a Constituição é um instrumento hermenêutico de conhecimento das normas constitucionais que impõe o recurso a estas para determinar e apreciar o conteúdo intrínseco da lei. Desta forma, o princípio da interpretação conforme a Constituição é mais um princípio de prevalência das normativo-vertical ou de integração hierárquico-normativa de que um simples princípio de conservação de normas." Cf. CANOTILHO, José Joaquim Gomes, Direito constitucional e teoria da constituição..., p. 1310.
} 


\subsubsection{LEGITIMIDADE DO PODER JUDICIÁRIO}

Ao contrário do que ocorre com os demais Poderes do Estado, a legitimidade da atividade judicante não advém do voto e da escolha pela maioria, mas sim da verdade das formulações judiciais e da liberdade dos cidadãos ${ }^{183}$. Se o órgão responsável pela garantia dos direitos fundamentais estivesse ligado aos interesses da maioria, os dissidentes da sociedade correriam perigo e seriam alvo de perseguição. Daí a relevância da independência da função judicial das demais funções estatais. Somente dessa maneira pode-se admitir algum pronunciamento que resulte numa restrição a direito fundamental, porquanto os riscos de ser viciado por algum interesse secundário são os menores possíveis. $^{184}$

Outrossim, conforme escólio de Ferrajoli, a legitimidade de uma sentença é extraída da apuração imparcial dos fatos, nunca do consenso da maioria, "que certamente não converte em verdadeiro o que é falso, nem em falso o que é verdadeiro. ". 185

Outro ponto relevante atinente à legitimação é escolha dos membros do Poder Judiciário, que Orlando Viegas Martins Afonso denomina de legitimidade de exercício. Afirma que o sistema de legitimação originária, não decorrente de sufrágio, mas sim de concurso público previsto no texto constitucional, é o mais adequado para escolher aqueles que exercerão a função de garante dos direitos fundamentais e atingir a verdade, a qual proporciona a legitimação externa à função jurisdicional. ${ }^{186}$ Ainda, segundo ele: “...os

\footnotetext{
${ }^{183}$ Para Ferrajoli, a verdade buscada por meio da instrução criminal é um meio de legitimação da atividade jurisdicional, sendo a única motivação apta a conferir legitimidade às decisões penais, mesmo que só possa ser obtida imperfeitamente, justamente em virtude do respeito às garantias individuais. Acrescente-se que para o autor, o juízo penal é uma combinação entre o saber e poder. $\mathrm{Na}$ medida em que se diminui o conhecimento acerca dos fatos da realidade, aumenta a discricionariedade da decisão, isto é, utiliza-se o poder, e vice-versa. Por essa razão, a busca da verdade é necessária como meio de proporcionar um processo que obedeça às garantias previstas no sistema. FERrAJOLI, Luigi, Direito e Razão, Ana Paula Zomer Sica, Fauzi Hassan Choukr, Juarez Tavares, Luiz Flávio Gomes (trad.), 2a. ed., São Paulo, Editora Revista dos Tribunais, 2006, p. 48-49.

${ }^{184}$ AfONSO, Orlando Viegas Martins, Poder Judicial..., p. 61. A autonomia perante os demais órgãos do Estado é chamada por Canotilho de independência externa, enquanto que a independência dentro dos quadros do Poder Judiciário é considerada independência interna. Ver CANOTILHO, José Joaquim Gomes, Direito constitucional e teoria da constituição..., p. 664.

${ }^{185}$ Ferrajol, Luigi, Jurisdição e democracia, Costa, Eduardo Maia (trad.) in Revista do Ministério Público, ano 18, out.-dez. 1997, n. ${ }^{\circ}$ 72, p. 17.

${ }^{186}$ AfOnso, Orlando Viegas Martins, Poder Judicial..., p. 54-61.
} 
consensos maioritários ou a seleção dos juízes pela via eleitoral nada acrescentam à legitimidade da jurisdição... "187

Assim, a necessidade de se atingir a verdade e de se proteger a liberdade dos indivíduos afastam o exercício da atividade jurisdicional de qualquer princípio de autoridade, bem como da vontade da maioria e conferem-no a pessoas selecionadas de acordo com seus conhecimentos jurídicos, reputação e outros fatores que a Constituição do país considerar relevantes.

Para uma melhor abordagem da questão, é oportuno fazer uma ligação com a natureza e conteúdo do ato praticado por um magistrado e, a partir daí, já passamos dissecar o conceito de independência e relacioná-la com outros atributos essenciais à atividade judicante.

Com efeito, para que um ato seja catalogado como materialmente jurisdicional, deve visar à resolução de conflito de interesses num caso concreto de forma definitiva e para um órgão ser considerado tribunal, além de ter o ato materialmente jurisdicional incluído no âmbito de sua competência, deve possuir independência subjetiva e objetiva, nos termos dos ensinamentos de Paulo Castro Rangel. ${ }^{188}$

Passamos, agora, portanto, à análise específica dos atributos essenciais da função jurisdicional, que lhe conferem a aura de guardião de valores fundamentais.

\subsubsection{INDEPENDÊNCIA OBJETIVA E SUBJETIVA (IMPARCIALIDADE E ISENÇÃO)}

Para Paulo Castro Rangel, enquanto a independência objetiva relaciona-se com a exclusiva submissão à lei e a autonomia com relação aos outros Poderes do Estado, a

\footnotetext{
${ }^{187}$ AfONSO, Orlando Viegas Martins, Poder Judicial..., p. 59.

${ }^{188}$ RANGEL, Paulo Castro, Reserva de Jurisdição..., p. 40-46.
} 
independência subjetiva tem a ver com a imparcialidade e com a isenção, além de exigir garantias para assegurá-la. Diz o autor:

“...a exigência indeclinável de que o órgão chamado a praticar um acto jurisdicional se apresente revestido das supra-mencionadas independência objectiva e subjectiva não é mais do que a positivação ou confirmação daquela idéia de necessária convergência entre uma dimensão material e uma dimensão organizatória da jurisdição, que havíamos apontado como o cerne da reserva de jurisdição, a título de pré-compreensão." "189

O tema da independência judicial é muito rico e possui diversas abordagens e classificações, algumas das quais já mencionamos. Dessa maneira, a terminologia dos demais autores estudados difere um pouco desta apresentada, mas a essência do pensamento é a mesma. Sempre nos depararemos com a questão da autonomia do Poder Judiciário com relação aos demais órgãos estatais, o que implica sua estrita submissão à lei, bem como com a independência pessoal de cada membro da magistratura.

Orlando Viegas Martins Afonso entende que a independência dos juízes como categoria $^{190}$ relaciona-se com o desenvolvimento do Estado de Direito e, por conseguinte, com o princípio da estrita legalidade, abordando os três planos da atividade judicante expostos acima. Ora, esta é a mesma idéia da independência objetiva de Paulo Castro Rangel, se considerarmos que a separação de poderes é um dos fundamentos do Estado Democrático de Direito da atualidade, conforme explanado em itens anteriores, uma vez que é uma forma garantística de conservação da liberdade e segurança individuais. ${ }^{191}$

\footnotetext{
${ }^{189}$ RANGEL, Paulo Castro, Reserva de Jurisdição..., p. 56.

${ }^{190}$ Para Canotilho, pode-se falar em independência coletiva quando tratamos da autonomia da magistratura como uma corporação. Cf. CANOTILHO, José Joaquim Gomes, Direito constitucional e teoria da constituição..., p. 663.

${ }^{191}$ Afonso, Orlando Viegas Martins, Poder Judicial..., p. 67 e 72. No mesmo sentido, MACHADO, Santiago Muñoz, La reserva de jurisdicción..., p. 12.
} 
Ainda, deve ser apontada a classificação de Santiago Muñoz Machado, para quem a independência opera de duas maneiras, positivamente, por meio da submissão ao ordenamento jurídico, e negativamente, indicando o impedimento dos magistrados sofrerem influência de outros órgãos. Perceba-se que as duas faces da independência judicial para este autor acabam se retroalimentando, uma vez que a submissão à lei só será plena se não houver uma estrutura hierárquica pressionando os magistrados. ${ }^{192}$

Canotilho utiliza a mesma denominação para se referir a fenômeno ligeiramente diverso. Para o autor português, independência dos tribunais sempre significará a separação da função de julgar, ora em sentido positivo, pois a função jurisdicional é atribuída exclusivamente aos juízes, ora em sentido negativo, por haver proibição da atuação de outros órgãos neste âmbito. Para o autor, a realidade descrita por Santiago Muñoz é classificada como independência externa ou interna. ${ }^{193}$

Dito isto, há que se observar que a independência do juiz, baseada na divisão de funções e na exclusividade do exercício da atividade jurisdicional pelos tribunais evoluiu para a independência subjetiva ou pessoal do juiz, a qual abrange os atributos da imparcialidade e isenção. ${ }^{194}$

Orlando Viegas Martins Afonso enxergou uma relação entre esses três atributos, asseverando que a independência garante a imparcialidade, enquanto que a esta garante a isenção. ${ }^{195}$

Para o autor, a imparcialidade é um atributo relativo ao âmbito processual, que pressupõe a configuração do processo como uma relação triangular na qual o juiz está

\footnotetext{
${ }^{192}$ MACHADO, Santiago Muñoz, La reserva de jurisdicción..., p. 26. Fazendo um paralelo com a classificação de Canotilho já mencionada na nota 184, trata-se da diferenciação entre independência externa e interna da magistratura. CANOTILHO, José Joaquim Gomes, Direito constitucional e teoria da constituição, $7^{\mathrm{a}}$ ed., Coimbra, Almedina, 2003, p. 664.

${ }^{193}$ CANOTILHO, José Joaquim Gomes, Direito constitucional e teoria da constituição..., p. 660 e 664.

${ }^{194}$ MACHAdo, Santiago Muñoz, La reserva de jurisdicción..., p.14; RANGEL, Paulo Castro, Reserva de Jurisdição..., p. 45-46.

${ }^{195}$ AfONSO, Orlando Viegas Martins, Poder Judicial..., p. 67
} 
super partes, não podendo estar comprometido com o interesse de nenhuma delas. Desta forma, também se está garantindo o tratamento igualitário entre os pólos processuais. ${ }^{196}$

A imparcialidade do juiz é característica essencial da atividade jurisdicional, pressuposto de sua própria existência. Sua exigência afasta causas objetivas que podem influenciar o julgador de alguma forma, determinando-se, por meio de regras concretas, aquele que será competente para proceder ao julgamento da forma mais neutra possível. Assim, não é uma mera garantia para a parte, mas sim, garantia da jurisdição como um todo. $^{197}$

Conquanto não preveja expressamente a garantia da imparcialidade dos julgadores, a Constituição Federal de 1988 estabelece a garantia do juiz natural que proíbe os tribunais de exceção e exige que as causas sejam julgadas pelo tribunal competente no inciso XXXVII do artigo $5^{\circ}$. Além disso, ao juiz são atribuídas garantias e impedimentos para afastá-lo de qualquer influência, os quais mencionaremos adiante. ${ }^{198}$

A isenção é condição indispensável para que haja Justiça no pronunciamento judicial. É uma qualidade íntima da figura do magistrado e exige que não esteja comprometido com seus próprios valores nem com os de qualquer segmento da sociedade, mas tão somente com seu profissionalismo. É algo bastante difícil de se implementar de forma absoluta, uma vez que exige a alienação da pessoa do juiz de suas paixões, simpatias e antipatias, que são intrínsecas a qualquer ser humano. Por tal razão, existem mecanismos

\footnotetext{
${ }^{196}$ AFONSO, Orlando Viegas Martins, Poder Judicial..., p. 66-69. Salientando a relação entre imparcialidade e igualdade, Cândido Rangel Dinamarco esclarece que "A imparcialidade, conquanto importantíssima, não é um valor e si própria mas fator para o culto de uma fundamental virtude democrática refletida no processo, que é a igualdade. Quer-se o juiz imparcial, para que dê tratamento igual aos litigantes ao longo do processo e na decisão da causa." DinAMARCo, Cândido Rangel, Instituições de Direito Processual Civil..., p. 201.

${ }^{197}$ Fernandes, Antonio Scarance, Processo Penal Constitucional, 5a Ed. rev,. atual e ampl., São Paulo, Editora Revista dos Tribunais, 2007, p. 133.

${ }^{198}$ Fernandes, Antonio Scarance, Processo Penal Constitucional..., p. 133; DinamarCo, Cândido Rangel, Instituições de Direito Processual Civil..., p. 201. Apesar de não haver dispositivo expresso nas leis brasileiras tratando da imparcialidade dos juízes, temos previsões em textos internacionais que integram nosso ordenamento, em virtude do $\S 2^{\circ}$ do artigo $5^{\circ}$ da nossa Constituição. São elas, o artigo $10^{\circ}$ da Declaração Universal dos Direitos do Homem ("Todo o homem tem direito, em plena igualdade, a uma justa e pública audiência por parte de um tribunal independente e imparcial, para decidir de seus direitos e deveres ou do fundamento de qualquer acusação criminal contra ele") e o artigo $8^{\circ}, 1$ do Pacto de San Jose da Costa Rica ("toda pessoa tem o direito de ser ouvida, com as devidas garantias e dentro de um prazo razoável, por um juiz ou tribunal competente, independente e imparcial, estabelecido anteriormente por lei...").
} 
com o condão de evitar que não participe do processo aquele que não possui condições de ser isento. ${ }^{199}$

Um parágrafo da obra de Orlando Afonso é esclarecedor para sintetizar o conceito desses atributos. Confira:

"Nenhum interesse ou vontade deve condicionar o seu julgamento. A imparcialidade é, como afirma Luigi Ferrajoli, uma alienidade do Juiz relativamente aos interesses das partes de um dado processo enquanto que a independência é a sua exterioridade em relação ao sistema político e, em geral, a todo e qualquer sistema de poderes. A imparcialidade é garantia da isenção do Juiz e condição da sua universalidade. ,200

Apresentados os conceitos dos atributos essenciais da função jurisdicionais, cabe verificar quais os mecanismos que o ordenamento coloca a nossa disposição para que eles sejam efetivos.

\subsubsection{GARANTIAS E INCOMPATIBILIDADES}

Canotilho esclarece que a independência pessoal dos juízes está intrinsecamente ligada às garantias e incompatibilidades. O mesmo é observado por Dinamarco. ${ }^{201}$

Nesse contexto, e aqui Santiago Muñoz é bem enfático, destaca-se a garantia da inamovibilidade, uma vez que a proibição de transferências, suspensões, aposentações ou

\footnotetext{
${ }^{199}$ AfONSO, Orlando Viegas Martins, Poder Judicial..., p. 65-66.

${ }^{200}$ AfONSO, Orlando Viegas Martins, Poder Judicial..., p. 67.

${ }^{201}$ CANOTILHO, José Joaquim Gomes, Direito constitucional e teoria da constituição..., p. 663; DiNAMARCO, Cândido Rangel, Instituições de Direito Processual Civil..., p. 202.
} 
demissões possibilitam que os juízes atuem sem temer represálias de patamares superiores do próprio Poder Judiciário ou de outros Poderes do Estado. ${ }^{202}$

Não se pode deixar de mencionar, entretanto, as demais garantias previstas no artigo 95 da Constituição brasileira, quais sejam, a vitaliciedade no cargo e da irredutibilidade de vencimentos, que também possibilitam uma atuação autônoma e destemida. No que tange à independência pessoal, ainda exercem papel relevante os critérios objetivos da carreira dos juízes consolidados no artigo 93. Por fim, as prerrogativas institucionais do artigo 96 da Constituição que conferem ao Poder Judiciário autonomia financeira e administrativa reforçam a independência do órgão. ${ }^{203}$

Já as regras de incompatibilidade visam a afastar os julgadores nos casos em que se presume a fragilização de sua capacidade de ser imparcial e isento. Com efeito, o juiz é um ser humano inserto na sociedade e, como tal, possui amigos, família e preferências, sendo impossível exigir que possua uma fortaleza moral e psíquica que lhe torne imune a qualquer influência. ${ }^{204}$

Devemos anotar que, no Processo Penal Brasileiro, o termo incompatibilidade não pode ser utilizado como gênero da forma que faz Canotilho. Isso porque o Código de Processo Penal divide as condições que perturbam a imparcialidade ou isenção do julgador em três espécies: suspeição, impedimento e incompatibilidade.

Denilson Feitoza afirma que a doutrina faz grande confusão entre esses conceitos. ${ }^{205}$ Fernando da Costa Tourinho Filho, por sua vez, diferencia a todos, mas anota que não há interesse prático em fazê-lo. ${ }^{206}$ De qualquer maneira, faremos breves considerações sobre essas categorias.

As causas de suspeição estão enumeradas no artigo 254 do Código de Processo Penal e relacionam-se com vínculos subjetivos que o juiz possui com alguma das partes.

\footnotetext{
${ }^{202}$ CANOTILHO, José Joaquim Gomes, Direito constitucional e teoria da constituição..., p. 663; DinAMARCO, Cândido Rangel, Instituições de Direito Processual Civil..., p. 202; MACHADO, Santiago Muñoz, La reserva de jurisdicción..., p. 14.

${ }^{203}$ Dinamarco, Cândido Rangel, Instituições de Direito Processual Civil..., p. 202.

${ }^{204}$ Idem, p. 223.

${ }^{205}$ PACHECO, Denilson Feitoza, Direito processual penal..., p. 555.

${ }^{206}$ TourinHo FILHO, Fernando da Costa, Manual de processo penal, $6^{\text {a }}$ ed. rev., atual., e aum., São Paulo, Editora Saraiva, 2004, p. 382.
} 
As causas de impedimento consistem em vínculos objetivos, fatos concretos, que impedem o magistrado de atuar em determinado processo e estão catalogados no artigo 252 do CPP. Por fim, as causas de incompatibilidade têm a ver com a impossibilidade de dois ou mais juízes atuarem conjuntamente em um órgão coletivo, nos termos do artigo 253 do CPP. ${ }^{207}$

Foge ao escopo deste trabalho fazer uma análise pormenorizada de cada uma das causas de suspeição, impedimento ou incompatibilidade. Para nós, basta afirmar que no caso de ser observada qualquer uma das causas, devem ser adotadas as medidas processuais aptas a sanar o vício. ${ }^{208}$

Por óbvio, o juiz pode se declarar suspeito ou impedido de ofício. Outrossim, embora o Código de Processo Penal silencie sobre a possibilidade do juiz declarar-se suspeito por motivo de foro íntimo, a doutrina admite a aplicação subsidiária do Parágrafo Único do artigo 135 do Código de Processo Civil, que admite tal postura. Esta manobra é fulcral para a garantia da isenção, que se relaciona mais diretamente com o afastamento dos valores pessoais do juiz. ${ }^{209}$

${ }^{207}$ PACHECO, Denilson Feitoza, Direito processual penal..., p. 562; TOURINHO FILHO, Fernando da Costa, Manual de processo penal..., p. 382. Os dispositivos legais mencionados seguem transcritos:

“Art. 252. O juiz não poderá exercer jurisdição no processo em que:

I - tiver funcionado seu cônjuge ou parente, consangüíneo ou afim, em linha reta ou colateral até o terceiro grau, inclusive, como defensor ou advogado, órgão do Ministério Público, autoridade policial, auxiliar da justiça ou perito;

II - ele próprio houver desempenhado qualquer dessas funções ou servido como testemunha;

III - tiver funcionado como juiz de outra instância, pronunciando-se, de fato ou de direito, sobre a questão;

IV - ele próprio ou seu cônjuge ou parente, consangüíneo ou afim em linha reta ou colateral até o terceiro grau, inclusive, for parte ou diretamente interessado no feito.

Art. 253. Nos juízos coletivos, não poderão servir no mesmo processo os juízes que forem entre si parentes, consangüíneos ou afins, em linha reta ou colateral até o terceiro grau, inclusive.

Art. 254. O juiz dar-se-á por suspeito, e, se não o fizer, poderá ser recusado por qualquer das partes:

I - se for amigo íntimo ou inimigo capital de qualquer deles;

II - se ele, seu cônjuge, ascendente ou descendente, estiver respondendo a processo por fato análogo, sobre cujo caráter criminoso haja controvérsia;

III - se ele, seu cônjuge, ou parente, consangüíneo, ou afim, até o terceiro grau, inclusive, sustentar demanda ou responder a processo que tenha de ser julgado por qualquer das partes;

IV - se tiver aconselhado qualquer das partes;

$V$ - se for credor ou devedor, tutor ou curador, de qualquer das partes;

Vl- se for sócio, acionista ou administrador de sociedade interessada no processo."

${ }^{208}$ TOURINHO FILHO, Fernando da Costa, Manual de processo penal..., p. 376-377.

${ }^{209}$ Idem, p. 376. 
Todas estas garantias e cuidados visam a assegurar a lisura, imparcialidade e isenção do julgamento, proporcionando um processo efetivamente justo com tratamento equânime entre as partes.

\subsubsection{BREVES CONCLUSÕES}

Diante de toda a estrutura exposta, resta patente a existência de um Poder Judiciário independente e incólume perante as possibilidades de influências e pressões para o melhor exercício de sua função jurisdicional de forma apartada das demais funções estatais. E a essência dessa função, nunca se pode esquecer, é justamente resolver conflitos de interesses de forma definitiva.

Essa independência, que decorre da essência do Estado Democrático de Direito, o qual exige a divisão das funções entre órgãos diferenciados e observância da legalidade, é imperiosa para assegurar a liberdade dos indivíduos, pois só um juiz livre de pressões externas pode impedir atitudes arbitrárias contra os cidadãos e, eventualmente, autorizar alguma restrição de direito individual em nome de algum interesse maior que por ele será considerado da forma mais independente, imparcial e isenta possível.

E neste ponto, o mesmo magistrado que goza de independência e tem o dever de isenção e imparcialidade em virtude de sua inserção em um Estado de Direito que exige o respeito à separação de poderes e à estrita legalidade, garante a dimensão substancial desse Estado Democrático de Direito por zelar pelo respeito aos direitos e garantias fundamentais dos indivíduos.

Observamos, portanto, uma relação de retroalimentação entre o Poder Judiciário e o Estado Democrático de Direito, na medida em que este possibilita que apenas aquele exerça a função jurisdicional e aquele garante o cerne deste, que são os direitos fundamentais. Neste ponto, deve-se reafirmar que o Poder Judiciário é considerado o órgão mais adequado para exercer a função jurisdicional, nos termos do modelo da justeza 
funcional mencionado anteriormente. Deste modo, apenas ele pronunciar-se-á sobre conflitos em que o interesse envolvido seja de extrema relevância, pois aqui está o núcleo da função jurisdicional.

Assim, afirmamos com Canotilho que a independência judicial exige o reconhecimento da reserva de jurisdição, ao mesmo tempo em que é essencial para sua existência, uma vez que só um órgão separado dos demais e livre de influências, sejam elas de partes processuais, sejam de valores sociais ou pessoais, é que tem condições de tomar decisões justas sobre temas especiais, notadamente, quando estão envolvidos conflitos entre interesses constitucionalmente protegidos e direitos fundamentais. Nesses casos, apenas os juízes podem se pronunciar, cabendo a eles a primeira e a última palavras. ${ }^{210}$

\subsubsection{A NATUREZA DOS DIREITOS FUNDAMENTAIS E A INDISPENSABILIDADE DE UMA DECISÃO JUDICIAL PARA SOLUCIONAR OS CONFLITOS ENTRE ELES}

Estamos partindo da premissa de que alguns conflitos entre interesses devem ser resolvidos única e exclusivamente mediante a intervenção do Poder Judiciário. A definição de quais interesses devem ser abençoados com esta proteção especial e a investigação acerca de sua natureza é essencial para embasar essa tese. Só assim poderemos estabelecer os critérios que nos levem à conclusão de que o juiz é o órgão apto a efetuar intervenções a direitos fundamentais e interesses constitucionalmente relevantes.

Faremos, portanto, uma digressão acerca da idéia de conteúdo essencial dos direitos fundamentais, passando por diversas teorias, chegando à uma sugestão de solução para os conflitos entre princípios e regras que justifique a necessidade da intervenção de um membro da magistratura.

${ }^{210}$ CANOtilho, José Joaquim Gomes, Direito constitucional e teoria da constituição..., p. 664. 


\subsubsection{CONTEÚDO ESSENCIAL DOS DIREITOS FUNDAMENTAIS E O SUPORTE FÁTICO DA NORMA}

$\mathrm{Na}$ esteira dos estudos realizados por Mauricio Zanoide de Moraes, que, por sua vez, utilizou muitos dados da obra de Virgílio Afonso da Silva, acolhemos a noção de conteúdo essencial de direito fundamental construída com fundamento na teoria dos princípios para identificar a legitimidade das intervenções aos direitos. ${ }^{211}$

Existem duas formas de se analisar o conteúdo essencial de um direito fundamental. A primeira identifica se o direito ou dever assegurado pela norma garante posições subjetivas ou se garante situações objetivas. Para a teoria objetiva, o conteúdo essencial é uma garantia do direito fundamental voltada a proteger o bem da vida nele abarcado. Assim, o conteúdo essencial tem por escopo limitar as intervenções indevidas nos direitos fundamentais como se eles fossem instituições objetivas do sistema jurídico. Almeja-se tornar o bem jurídico em questão realidade para toda a comunidade, de maneira que para haver uma lesão, o direito deveria perder sua proteção como instituição jurídica coletiva. ${ }^{212}$

Já para a teoria subjetiva, o conteúdo essencial consiste na garantia dos direitos fundamentais como direitos subjetivos que impedem intervenções excessivas ou ilegítimas nas posições jurídicas individuais. Não basta garantir normativamente o direito a toda a comunidade, pois tal postura não impede que o direito seja negado integralmente a um determinado indivíduo e, caso isso ocorra, estará configurada a lesão. ${ }^{213}$

Diante desse quadro:

"essas formas objetiva e subjetiva de compreender o conteúdo essencial dos direitos fundamentais não se excluem, mas, ao contrário, se inter-relacionam e se

\footnotetext{
${ }^{211}$ MoraEs, Maurício Zanoide de, Presunção de inocência..., p. 298-299; SILVA, Virgílio Afonso da, Direitos Fundamentais: conteúdo essencial, restrições e eficácia, São Paulo, Malheiros Editores, 2009.

${ }^{212}$ Moraes, Maurício Zanoide de, Presunção de inocência..., p. 301; Silva, Virgílio Afonso da, Direitos Fundamentais..., p. 26, 27 e 185.

${ }^{213}$ Moraes, Maurício Zanoide de, Presunção de inocência..., p. 302; Silva, Virgílio Afonso da, Direitos Fundamentais..., p. 27 e 186.
} 
complementam a fim de garantir uma maior efetividade às normas fundamentais". ${ }^{214}$

No entanto, essas teorias não explicam adequadamente o exame das intervenções estatais nos direitos individuais. Para tanto, ganha importância a perspectiva das teorias absoluta e relativa. Para a primeira, o âmbito de proteção de um direito possui uma barreira intransponível independente dos valores que estiverem em jogo no caso concreto. Já para a segunda, a definição do que é essencial dependerá das condições fáticas e das colisões entre interesses no caso concreto. ${ }^{215}$

Mas para o melhor entendimento do significado do conteúdo essencial, bem como da visão adotada pelos autores que seguimos, é indispensável compreender alguns conceitos centrais na teoria dos direitos fundamentais. Virgílio Afonso da Silva faz o seguinte esclarecimento na introdução de sua obra, que também serve para explicar as definições que buscaremos dar a seguir:

"Quando se define parte do objeto deste trabalho como 'o conteúdo essencial dos direitos fundamentais', quer-se fazer referência a um fenômeno complexo, que envolve uma série de problemas inter-relacionados. Esses problemas, que compõem o objeto principal do trabalho são: (a) a definição daquilo que é protegido pelas normas de direitos fundamentais; (b) a relação entre o que é protegido e suas possiveis restrições; e (c) a fundamentação tanto do que é protegido como de suas restrições. É da relação dessas variáveis - e de todos os problemas que as cercamque se define, na visão deste trabalho, o conteúdo essencial dos direitos fundamentais. "216

\footnotetext{
${ }^{214}$ MORAES, Maurício Zanoide de, Presunção de inocência..., p. 302.

${ }^{215}$ Moraes, Maurício Zanoide de, Presunção de inocência..., p. 303; SILVA, Virgílio Afonso da, Direitos Fundamentais..., p. 27.

${ }^{216}$ SILVA, Virgílio Afonso da, Direitos Fundamentais..., p. 28.
} 
Pois bem. Para delimitar o que é protegido pelas normas de direitos fundamentais devemos recorrer ao conceito de suporte fático que, por sua vez, tem mais de uma acepção, sendo necessário fazer a escolha por uma delas.

O suporte fático é formado pelo fato, ato ou situação jurídica inseridos no âmbito de proteção da norma. Sua faceta abstrata compreende todos os fatos, atos, situações da vida e bens jurídicos protegidos pelo enunciado de uma norma fundamental. Já seu aspecto concreto revela-se na ocorrência daquilo que estava previsto no texto legal. ${ }^{217}$

É interessante anotar que o suporte fático é composto por mais de um elemento. Não é formado apenas pelo bem jurídico protegido, aqui chamado de âmbito de proteção, mas também pela intervenção que pode sofrer. Adiciona-se, ainda, um terceiro fator, a existência ou não de justificação constitucional para esta intervenção. Se houver esta justificação, a intervenção será legítima, caso em que é denominada de restrição. Quando for ilegítima, é denominada violação, e acaba acarretando uma conseqüência negativa. ${ }^{218}$

Definidos os elementos que compõem o suporte fático da norma, devemos analisar sua amplitude, o que terá o condão de influenciar o controle das restrições a direitos fundamentais. Com efeito, existem duas teorias acerca deste ponto, a ampla e a restrita. Considerando que a teoria dos princípios tem maior preocupação em preservar os direitos fundamentais, seus adeptos dão preferência à teoria ampla do suporte fático da norma, razão pela qual daremos destaque a ela neste estudo. ${ }^{219}$

Adotando-se a teoria ampla, define-se, num primeiro momento, aquilo que a norma visa a proteger. No entanto, algumas condutas e situações podem ser excluídas se houver uma ponderação entre o bem protegido e a necessária intervenção estatal no caso concreto. Assim, temos aquilo que é protegido prima facie e o que é protegido definitivamente, de

\footnotetext{
${ }^{217}$ Moraes, Maurício Zanoide de, Presunção de inocência..., p. 309; SILVA, Virgílio Afonso da, Direitos Fundamentais..., p. 67 e 68.

${ }^{218}$ Moraes, Maurício Zanoide de, Presunção de inocência..., p. 309-310; SILVA, Virgílio Afonso da, Direitos Fundamentais..., p. 71-75.

${ }^{219}$ Ambas as teorias consideram que os direitos constitucionais, por terem estrutura de normas-princípios, são restringíveis. A diferença está no momento em que o suporte fático é reduzido e na forma como isto se operacionaliza. Para a teoria restrita, a redução é feita no momento em que se concebe o conteúdo do âmbito de proteção. Já para a ampla, a definição do bem protegido é o passo inicial, após o que pode haver uma exclusão de situações mediante o sopesamento de valores. MORAES, Maurício Zanoide de, Presunção de inocência ..., p. 312-315; SILVA, Virgílio Afonso da, Direitos Fundamentais..., p. 78-112.
} 
modo que esta análise individualizada se mostra fundamental para a compreensão do conteúdo essencial da norma e só pode ser feita por um magistrado no momento da resolução do caso concreto. ${ }^{220}$

Desta forma, essa teoria oferece a inegável vantagem de proporcionar maior atualidade à interpretação da norma, além do que:

“...tanto o 'âmbito de proteção' como a 'intervenção' são tomados, igualmente, da forma mais abrangente possível, a fim de que eventual redução seja feita no instante de se chegar 'ao direito definitivo', determinado em face do caso concreto., 221

O grande benefício para os direitos fundamentais consiste no fato de que as margens de sua proteção serão estendidas. Nos termos de Virgílio Afonso da Silva:

"Ora, se a proteção definitiva de um direito fundamental depende da classificação de uma intervenção em seu âmbito ou como restrição constitucionalmente aceita ou como violação inconstitucional, tanto mais tende a ser efetiva essa proteção quanto maior for a extensão do âmbito de proteção e também do conceito de 'intervenção'., ,222

\footnotetext{
${ }^{220}$ Moraes, Maurício Zanoide de, Presunção de inocência..., p. 315; SILVA, Virgílio Afonso da, Direitos Fundamentais..., p. 109.

${ }^{221}$ MORAES, Maurício Zanoide de, Presunção de inocência..., p. 316.

${ }^{222}$ SILVA, Virgílio Afonso da, Direitos Fundamentais..., p. 111-112.
} 
Neste ponto devemos lembrar que os direitos fundamentais processuais penais são direitos de defesa ${ }^{223}$, de sorte que consistem em garantias dos indivíduos contra invasões estatais ilegítimas, que é o ponto central do estudo. ${ }^{224}$

Como já dito acima, as intervenções legítimas são denominadas restrições, enquanto que as ilegítimas são catalogadas como violações. Neste ponto, também existem duas teorias: a interna e a externa. ${ }^{225}$

A teoria interna acredita na existência de um único elemento: o direito em sua formação definitiva e previamente determinado em extensão e limites. Por esta visão, a noção de restrição é substituída pela de limite, o qual já está inserto no conceito de direito. Por isso fala-se em limites imanentes. ${ }^{226}$

Já para a teoria externa, os direitos fundamentais são uma categoria apartada das eventuais restrições a eles impostas e só se relacionam em virtude da necessidade de se compatibilizar os direitos. ${ }^{27}$ Por amor à coerência, se adotamos, na esteira do posicionamento de Maurício Zanoide de Moraes, a teoria dos princípios e a noção de suporte fático amplo, devemos adotar esta teoria externa que compreende a restrição como algo apartado do direito. ${ }^{228}$

Observe-se que só tem cabimento falar em aplicação do postulado da proporcionalidade se adotarmos a teoria externa e o suporte fático amplo, pois a restrição será empreendida num momento posterior ao da definição do âmbito de proteção do direito. $^{229}$

\footnotetext{
${ }^{223}$ Essa é a terminologia utilizada por Alexy para designar os direitos de primeira geração. Para o autor, os direitos em face do Estado consistentes em ações negativas correspondem aos chamados direitos de defesa. Ver AleXY, Robert, Teoria dos Direitos Fundamentais, Virgílio Afonso da Silva (trad.), São Paulo, Malheiros Editores, 2008, p. 195-196.

${ }^{224}$ Moraes, Maurício Zanoide de, Presunção de inocência..., p. 319.

${ }^{225}$ SILVA, Virgílio Afonso da, Direitos Fundamentais..., p. 127.

${ }^{226}$ MORAES, Maurício Zanoide de, Presunção de inocência..., p. 320.

${ }^{227}$ SILVA, Virgílio Afonso da, Direitos Fundamentais..., p. 138.

${ }^{228}$ MORAES, Maurício Zanoide de, Presunção de inocência..., p. 321.

${ }^{229}$ Moraes, Maurício Zanoide de, Presunção de inocência..., p. 322; SILVA, Virgílio Afonso da, Direitos Fundamentais..., p. 138. É esclarecedora a transcrição de um trecho desta página: "Isso porque é somente a partir do paradigma da teoria externa - segundo o qual as restrições, qualquer que seja sua natureza, não têm qualquer influência no conteúdo do direito, podendo apenas, no caso concreto, restringir seu exercício que se pode sustentar que, em uma colisão entre princípios, o princípio que tem de ceder em favor de outro não tem afetadas sua validade e, sobretudo, sua extensão prima facie."
} 
Aliás, é muito importante ressaltar que a restrição de um direito fundamental só pode se dar em virtude de uma norma constitucional, podendo-se entender dessa forma normas diretamente vinculadas ao capítulo de direitos fundamentais da constituição (normas restritivas diretamente constitucionais) sejam as próprias normas constitucionais em contradição ou as cláusulas restritivas inseridas pelo constituinte, sejam normas inferiores elaboradas em decorrência de determinação constitucional (normas restritivas indiretamente constitucionais), que são as reservas legais constitucionais. É a chamada justificação constitucional para a restrição que, para Dimitri Dimoulis e Leonardo Martins, na linha do exposto acima, deriva da complexa relação entre as normas de direitos fundamentais e o direito infraconstitucional. ${ }^{230}$

As cláusulas restritivas, no âmbito da teoria dos princípios, são identificadas como uma espécie de restrição ao âmbito de proteção do direito fundamental, podendo ser expressas ou tácitas. Sua estrutura normativa é de regra, sendo inserida dentro de um mandado de otimização como não-direito definitivo. Essa abordagem da teoria dos princípios é bem mais segura do que a dos limites imanentes, principalmente no que tange às clausulas restritivas tácitas, que dependem da adequada compreensão da colisão entre as normas. $^{231}$

Após toda esta exposição acerca de como devemos entender a estrutura de um direito fundamental e sua eventual restrição, é natural passarmos à análise da forma de solução dos conflitos entre as normas, sempre com vistas a encontrar a justificativa para a necessidade da presença de um juiz para decidir em alguns desses casos.

\footnotetext{
${ }^{230}$ Moraes, Maurício Zanoide de, Presunção de inocência..., p. 325-326; Dimoulis, Dimitri e MARTINS, Leonardo, Teoria Geral dos Direitos Fundamentais, São Paulo, Editora Revista dos Tribunais, 2006, p. 148. A propósito, os autores enumeram quatro situações em que uma intervenção será constitucionalmente justificada: quando o comportamento não se situar na área de proteção do direito; quando a intervenção representar a concretização de um limite constitucional derivado do direito constitucional de colisão; quando uma norma infraconstitucional restringe o direito de acordo com a permissão constitucional mediante reserva legal; e quando houver colisão entre um direito fundamental e um princípio de interesse geral. Ver p. 149150 .

${ }^{231}$ Moraes, Maurício Zanoide de, Presunção de inocência..., , p. 327-328.
} 


\subsubsection{CONFLITOS ENTRE NORMAS E SUAS SOLUÇÕES}

A teoria dos princípios é a que mais se coaduna com a definição do conteúdo da norma fundamental e suas formas de restrição, de maneira que colabora para a solução dos casos de contradição normativa. Considerando a existência de duas espécies de normas, as regras e os princípios ${ }^{232}$, podemos vislumbrar a ocorrência de três formas de colisão: entre regras, entre princípios e entre princípios e regras. ${ }^{233}$

Não há dúvidas de que as normas de direitos fundamentais, em sua maioria, possuem natureza principiológica. Se houver contraposição entre os mandamentos contidos em cada um deles, estaremos diante de um caso de colisão. As colisões de direitos fundamentais, conforme Canotilho, podem se dar de duas maneiras:

"De um modo geral, considera-se existir uma colisão autêntica de direitos fundamentais quando o exercício de um direito fundamental por parte de seu titular colide com o exercício do direito fundamental por parte de outro titular. Aqui não estamos perante um cruzamento ou acumulação de direitos (como na concorrência de direitos), mas perante um choque, um autêntico conflito de direitos. A colisão de direitos em sentido impróprio tem lugar quando o exercício de um direito fundamental colide com outros bens constitucionalmente protegidos.

\footnotetext{
${ }^{232}$ Por mais que os conceitos de regra e princípio sejam conhecidos, não é demais consignar que, para Alexy, regras e princípios são normas, pois ambos dizem o que deve ser, fazendo parte do plano deôntico. Dentre as teses acerca da diferenciação dessas espécies normativas, Alexy se filia àquela que enxerga uma diferença qualitativa entre elas. Nesse sentido: “... princípios são normas que ordenam que algo seja realizado na maior medida possível, dentro das possibilidades jurídicas e fáticas existentes. Princípios são, por conseguinte, mandamentos de otimização, que são caracterizados por poderem ser satisfeitos em graus variados e pelo fato de que a medida devida de sua satisfação não depende somente das possibilidades fáticas, mas também das possibilidades jurídicas. O âmbito das possibilidades jurídicas é determinado pelos princípios e regras colidentes. Já as regras são normas que são sempre ou satisfeitas ou não satisfeitas. Se uma regra vale, então, deve se fazer exatamente aquilo que ela exige; nem mais, nem menos. Regras contêm, portanto, determinações no âmbito daquilo que é fática e juridicamente possível.” Cf. ALEXY, Robert, Teoria dos Direitos Fundamentais..., p. 87-90.

${ }^{233}$ Moraes, Maurício Zanoide de, Presunção de inocência..., p. 332.
} 
A colisão ou conflito de direitos fundamentais encerra, por vezes, realidades diversas nem sempre diferenciadas com clareza". ${ }^{234}$

A colisão de que tratamos neste trabalho é, em geral, do segundo tipo, isto é, em sentido impróprio, porquanto os meios de prova e de obtenção de prova que dependem de autorização judicial, sobre os quais trataremos pormenorizadamente adiante, envolvem o conflito de direitos individuais com o interesse público, que abarca o interesse da persecução criminal, protegido pelo ordenamento jurídico.

Observe-se que haverá essa colisão entre princípios no campo teórico e é nesta espécie de contradição que encontraremos a resposta para nossa indagação acerca da necessidade de haver uma decisão judicial quando existem conflitos entre interesses constitucionalmente protegidos. No entanto, na prática da área criminal, em decorrência de mandamentos constitucionais que exigem a previsão de leis para a restrição de direitos fundamentais, observamos a ocorrência com mais freqüência da colisão entre princípios e regras. $^{235}$

Mas este fato não alterará substancialmente a direção da nossa análise, uma vez que o conflito entre princípios e regras acaba sendo solucionado da mesma forma. Isso porque há a percepção de que não se está diante de uma regra propriamente dita. Na verdade, capta-se o princípio que está por detrás dessa regra e que lhe suporta, de maneira que o sopesamento será a forma de resolução, assim como ocorre no conflito entre princípios. ${ }^{236}$

De acordo com Virgilio Afonso da Silva, esta solução é apresentada com base em duas notas de rodapé da obra de Alexy, mas apresenta alguns problemas. Para o constitucionalista, não há, de fato, uma relação de colisão, mas sim uma relação de restrição, da qual a regra torna-se expressão. Na verdade, a colisão entre os princípios já foi objeto de apreciação pelo legislador, no momento da elaboração do texto normativo, quando deve ter efetuado o sopesamento dos valores envolvidos. Assim, ela seria aplicada

\footnotetext{
${ }^{234}$ CANOTILho, José Joaquim Gomes, Direito constitucional e teoria da constituição..., p. 1270.

${ }^{235}$ Moraes, Maurício Zanoide de, Presunção de inocência..., p. 343.

${ }^{236}$ Idem, p. 339.
} 
por subsunção quando o quadro fático apresentado se mostrasse adequado e seria afastada na situação contrária. ${ }^{237}$

No entanto, algumas situações apresentam maiores dificuldades e é bom mencionálas, porquanto são passíveis de serem constatadas na prática processual penal. A primeira é quando houver dúvidas acerca da constitucionalidade da regra. Neste caso, ou decide-se por sua constitucionalidade e pela consequiente aplicação por subsunção, ou por sua inconstitucionalidade em face de outro princípio, quando seria afastada. ${ }^{238}$

Situação mais complexa ocorre quando a aplicação da regra por subsunção resulta num panorama incompatível com algum princípio constitucional relevante, mas não de forma a resultar na inconstitucionalidade da regra. Neste caso, a solução efetivamente será um sopesamento entre o princípio que sustenta a regra e o princípio com ela colidente, mas apenas até se criar uma regra de exceção que passará a ser aplicada por subsunção aos demais casos. $^{239}$

Sendo assim, precederemos à análise da solução de conflitos para a colisão entre princípios, que ocorre quando duas ou mais normas principiológicas regulam a mesma situação concreta. Nesses casos, deve-se criar uma relação condicionada de precedência. ${ }^{240}$ Nesse sentido:

“... as incidências das cláusulas restritivas (expressas ou tácitas) no âmbito dos direitos prima facie devem ser decididas por meio das 'leis de colisão' entre normas-regras e normas-princípio, pois também a contradição normativa é forma de restrição de direitos fundamentais. "241

\footnotetext{
${ }^{237}$ SILVA, Virgílio Afonso da, Direitos Fundamentais..., p. 52.

${ }^{238}$ Silva, Virgílio Afonso da, Direitos Fundamentais...,: p. 52-53.

${ }^{239}$ Idem, p. 53-54.

240 Moraes, Maurício Zanoide de, Presunção de inocência..., p. 335; ALEXY, Robert, Teoria dos Direitos Fundamentais..., p. 93.

${ }^{241}$ Moraes, Maurício Zanoide de, Presunção de inocência..., p. 331.
} 
Antes de proceder a qualquer ponderação entre os princípios envolvidos, Canotilho sugere que se averigúe o âmbito de proteção dos direitos em questão, pois pode ocorrer de a situação alegada não estar contida no Tatbestand (âmbito de proteção) do direito constitucionalmente protegido. Entretanto, se mesmo após essa etapa a harmonização não for possível, cumpre determinar a relação de prevalência entre os princípios em conflito, mediante uma ponderação. ${ }^{242}$

Para determinar a relação de precedência, Alexy propõe a chamada "lei de colisão", segundo a qual:

"Levando-se em consideração o caso concreto, o estabelecimento de relações de precedências condicionadas consiste na fixação de condições sob as quais um princípio tem precedência em face do outro. Sob outras condições, é possível que a questão da precedência seja resolvida de forma contrária. "243

Disso se depreende que ao se efetuar a ponderação entre os princípios envolvidos, formula-se uma norma de direito fundamental com caráter de regra que estabelece as condições nas quais um determinado princípio prevalecerá sobre outro, o que implica a restrição de um deles. ${ }^{244}$ Isso pode ocorrer tanto no âmbito judicial quanto no âmbito legislativo. $^{245}$

É importante observar, entretanto, que não é possível estabelecer uma relação absoluta de precedência. Isso porque não é possível garantir que o resultado da relação condicionada obtida em uma determinada situação concreta se repetirá quando as condições forem alteradas. Assim, a ponderação casuística sempre será necessária. O máximo que se admite é a formulação de uma regra de reforço de argumentação, de modo

\footnotetext{
${ }^{242}$ CANOTILHO, José Joaquim Gomes, Direito constitucional e teoria da constituição..., p. 1274.

243 ALEXY, Robert, Teoria dos Direitos Fundamentais..., p. 96.

${ }^{244}$ Idem, p. 99.

${ }^{245}$ CANOTILHO, José Joaquim Gomes, Direito constitucional..., p. 1274.
} 
que se dê, em casos de dúvida, preferência a um princípio constitucional, como se faz com a presunção de inocência, devido processo legal e dignidade da pessoa humana. ${ }^{246}$

Conforme já observamos, sendo adeptos da teoria que defende o suporte fático amplo, entendemos que as restrições são efetuadas em um momento posterior ao da concepção do direito. Definido o que se visa a proteger, passa-se a excluir algumas situações por meio de uma ponderação entre o bem protegido e a necessária intervenção estatal no caso concreto. Assim, temos aquilo que é protegido prima facie e o que é protegido definitivamente, de modo que esta análise individualizada mostra-se essencial para a compreensão do conteúdo essencial da norma e só pode ser feita por um magistrado no momento da resolução do caso concreto. ${ }^{247}$

Da mesma forma que o âmbito de proteção é passível de sofrer limitações, sua posterior restrição também não pode ser ilimitada. Por tal motivo, são utilizados dois mecanismos para limitar as restrições: a proporcionalidade e o conteúdo essencial dos direitos fundamentais. ${ }^{248}$

Fica claro, portanto, que a proporcionalidade é uma importante restrição às restrições dos direitos fundamentais. Nos termos de Alexy, o próprio caráter de princípio, bem como a essência dos direitos fundamentais, implica a máxima da proporcionalidade e seus três "subprincípios" (adequação, necessidade e proporcionalidade em sentido estrito). 249

Com efeito, quando ocorrem colisões entre princípios, é forçosa a realização de uma ponderação, do que decorre a proporcionalidade em sentido estrito. Nesse sentido, temos que os princípios são mandados de otimização com relação às possibilidades jurídicas existentes no caso concreto. De outra banda, as máximas de necessidade e adequação também decorrem da necessidade de ponderação dos princípios, pois se busca uma otimização das situações fáticas. ${ }^{250}$ Assim, podemos concluir que o postulado da

\footnotetext{
${ }^{246}$ Moraes, Maurício Zanoide de, Presunção de inocência..., p. 337.

${ }^{247}$ Moraes, Maurício Zanoide de, Presunção de inocência..., p. 315.

${ }^{248}$ Idem, p. 344.

${ }^{249}$ ALEXY, Robert, Teoria dos Direitos Fundamentais..., p. 116.

${ }^{250}$ AlEXY, Robert, Teoria dos Direitos Fundamentais..., p.117-118. BARROS, Suzana de Toledo, O princípio da proporcionalidade e o controle de constitucionalidade das leis restritivas de direitos fundamentais, $3^{\mathrm{a}} \mathrm{ed}$., Brasília, Brasília Jurídica, 2003, p. 160. Nessa esteira, Nicolas Gonzalez-Cuellar Serrano refere-se à
} 
proporcionalidade é edificado em virtude da racionalização de soluções concretas para o conflito de direitos e bens tutelados. ${ }^{251}$

Ao lado da proporcionalidade, como dito, está a noção de proteção ao conteúdo essencial. Ela se sustenta na idéia de que o direito fundamental deve possuir algo cuja limitação não possa ser feita sem a devida justificação constitucional. É uma resistência à invasão indevida. Todavia, deve-se ter a preocupação de determinar de forma coerente aquilo que é protegido pela norma. Nesse panorama, Maurício Zanoide de Moraes relata que, anteriormente, defendia que todo direito fundamental possuía um conteúdo essencial irredutível. No entanto, seu posicionamento foi alterado, após perceber que na prática não era capaz de encontrar parte de um princípio que estivesse imune a toda e qualquer intervenção estatal. ${ }^{252}$ Esse novo entendimento encontrou respaldo na obra de Virgílio Afonso da Silva, que adotou a idéia de conteúdo essencial relativo:

"Se, na visão deste trabalho, como foi ressaltado, o conteúdo essencial dos direitos fundamentais é definido, a partir da relação entre diversas variáveis - e de todos os problemas que as cercam -, como o suporte fático dos direitos fundamentais (amplo ou restrito) e a relação entre os direitos e suas restrições (teorias externa ou interna), a opção fundamentada ao longo de todos os capítulos precedentes já definiu, automaticamente, a opção por um modelo de garantia do conteúdo essencial dos direitos fundamentais: o modelo relativo, sobretudo em seu enfoque subjetivo ${ }^{253}$

Dessa forma, apesar da sedução que provoca a idéia de que uma parte do direito fundamental seja irrestringível, a qual se fundamenta na teoria absoluta, não é possível

adequação e à necessidade como elementos empíricos da relação meio-fim, enquanto a proporcionalidade em sentido estrito seria baseada no elemento valorativo do esquema em questão. V. SERRANO, Nicolas GonzalezCuellar, Proporcionalidad y derechos fundamentales em el proceso penal, Madrid, Editorial Colex, 1990, p. 155 .

${ }^{251}$ Stumm, Raquel Denize, Princípio da proporcionalidade no direito constitucional brasileiro, Porto Alegre, Livraria do Advogado, 1995, p. 77-78.

${ }^{252}$ Moraes, Maurício Zanoide de, Presunção de inocência..., p. 363-366.

${ }^{253}$ Silva, Virgílio Afonso da, Direitos Fundamentais..., p. 206. 
delimitá-la de forma segura. Por isso o autor considera mais adequado se filiar à teoria relativa do conteúdo essencial, para a qual a definição daquilo que deve ser considerado essencial depende das condições fáticas e das colisões de direitos no caso concreto, de maneira que o conteúdo essencial varia dependendo da situação com a qual nos deparamos. ${ }^{254}$

É patente a relação entre este posicionamento e a aplicação do postulado da proporcionalidade. Considerando as inúmeras questões relevantes atinentes a este tema, passamos à sua análise pormenorizada num item apartado.

\subsubsection{O POSTULADO DA PROPORCIONALIDADE}

A importância da aplicação deste postulado no domínio da instrução criminal, tanto no que tange às leis que a regulam, quanto no que se refere às decisões de casos concretos, é que ele possui um caráter bidirecional, isto é, não permite a violação dos direitos fundamentais indiscriminadamente em favor de uma "pseudo-eficiência persecutória", mas autoriza uma escolha entre duas opções: favorecer o ius persecuciones ou garantir os direitos fundamentais ${ }^{255}$ nas situações em que existe uma relação de causalidade entre um meio e um fim. ${ }^{256}$ Tudo depende das circunstâncias presentes em cada caso particular.

Segundo Dimitri Dimoulis e Leonardo Martins, a proporcionalidade foi introduzida com sucesso nos estudos acadêmicos porque permite adaptações a situações concretas, modificando as formas de justificação e resultados dentro do ordenamento jurídico. Em geral, é vista com bons olhos pelo Poder Judiciário, uma vez que apregoa a utilização de

\footnotetext{
${ }^{254}$ MORAES, Maurício Zanoide de, Presunção de inocência..., p. 366-367.

${ }^{255}$ MORAES, Maurício Zanoide de, Interceptação Telefônica (L. 9.296/96), in Franco, Alberto Silva e Stoco, Rui (coord.), Leis Penais e sua Interpretação Jurisprudencial, 7 ed. rev., atual. e ampl., São Paulo, Editora Revista dos Tribunais, 2001, p. 1799.

${ }^{256}$ ÁvIla, Humberto, Teoria dos princípios: da definição à aplicação dos princípios jurídicos, 4a ed., São Paulo, Malheiros Editores, 2005, p. 112.
} 
técnicas abertas de ponderação, possibilitando maior intervenção judicial no âmbito das decisões legislativas ao mesmo tempo em que oferece justificativas jurídicas para tanto. ${ }^{257}$

Grande parte da doutrina entende que a proporcionalidade tem natureza de princípio, fazendo menção ao "princípio da proporcionalidade". ${ }^{258}$ Entretanto, esse não é o melhor entendimento. De acordo com Humberto Ávila, além das espécies de normas comumente usadas (princípios e regras), temos em nosso ordenamento os chamados postulados ou normas de segundo grau. Eles diferem dos princípios porquanto não visam à promoção de um fim, mas estruturam a aplicação do dever de promovê-lo. Na verdade, os postulados servem como "normas estruturantes de aplicação de princípios e regras". 259

Nesse sentido, o autor considera que a proporcionalidade não integra a categoria dos princípios, uma vez que a ela não se subsume uma situação fática. Sua aplicação se dá com relação a outras normas, para garantir sua devida realização. Destarte, a proporcionalidade se caracteriza como um postulado normativo aplicativo específico, por exigir o relacionamento entre certos elementos e por determinar os critérios orientadores de tal relação. ${ }^{260}$

Virgílio Afonso da Silva, embora não considere a denominação equivocada, esclarece que entende que a proporcionalidade tem a estrutura de regra, de maneira que prefere chamar a regra da proporcionalidade desta forma. ${ }^{261}$ Embora respeitemos a opinião do autor, adotaremos a expressão "postulado", por transparecer a idéia de que a proporcionalidade é uma metanorma.

Feitas essas considerações iniciais, observamos que o postulado da proporcionalidade atua em dois níveis distintos: o campo legislativo-abstrato, pelo qual o

\footnotetext{
${ }^{257}$ Dimoulis, Dimitri e MARTIns, Leonardo, Teoria Geral dos Direitos Fundamentais..., p. 178.

${ }^{258}$ CANOTILHO, José Joaquim Gomes, Direito constitucional e teoria da constituição..., p. 267; MORAES, Maurício Zanoide de, Interceptação Telefônica..., p. 1799; SERRANO, Nicolas Gonzáles-Cuellar, Proporcionalidad y derechos fundamentales..., p. 17, entre outros.

${ }^{259}$ SERRANO, Nicolas Gonzáles-Cuellar, Proporcionalidad y derechos fundamentales..., p. 88-90.

260 Ávila, Humberto, Teoria dos princípios..., p. 90 e 94. GRAU, Eros Roberto, O direito posto e o direito pressuposto..., p. 219-221. Cumpre esclarecer, ainda, que Humberto Ávila diferencia postulados inespecíficos, que exigem relacionamento entre certos elementos, mas não determinam os critérios que devem orientar sua relação e postulados específicos, que estabelecem tais critérios. São postulados da primeira espécie a ponderação, a concordância prática e a proibição de excesso, enquanto a igualdade, a razoabilidade e a proporcionalidade são da segunda espécie. V. op. cit. p. 93-110.

${ }^{261}$ SILVA, Virgílio Afonso da, Direitos Fundamentais..., p. 168-169.
} 
Judiciário verifica se a edição das normas respeitaram a justificação constitucional e o campo concreto da aplicação e execução das leis pelo Judiciário e Executivo. Este último é o mais importante na área de Processo Penal, pois mesmo uma lei que tenha sido elaborada de acordo com a justificação constitucional pode mostrar-se desproporcional se sua aplicação for abusiva. ${ }^{262}$

Diante desta conjuntura, antes de se analisar os elementos do postulado da proporcionalidade comumente tratados nas obras que se preocupam mais com o âmbito legislativo e controle de constitucionalidade, a adequação, necessidade e proporcionalidade em sentido estrito, devem se fixar alguns outros pontos relevantes. Assim, o exame da proporcionalidade deve ser feito tendo em vista a existência de pressupostos (legalidade e justificação) e requisitos extrínsecos (judicialidade e motivação). ${ }^{263}$

A constatação da necessidade de verificação desses itens prévios foi feita na obra de Nicolas Serrano Gonzáles-Cuéllar, ${ }^{264}$ que estruturou a aplicação do postulado em apreço de uma maneira mais completa.

Os pressupostos definidos pelo autor espanhol são a legalidade e a justificação teleológica. No que tange ao primeiro, deve-se destacar que a restrição de um direito fundamental depende de uma previsão legal anterior. Além disso, as situações que autorizam a limitação devem ser descritas de forma precisa ou precisável de acordo com critérios pré-determinados. Com relação à justificação teleológica, faz-se necessário que a restrição atenda a fins estatais legítimos, isto é, valores que estejam protegidos constitucionalmente, além de possuírem grande relevância social. ${ }^{265}$

A judicialidade e a motivação são os requisitos extrínsecos, sendo este um requisito formal e aquele subjetivo.

\footnotetext{
${ }^{262}$ MoRAES, Maurício Zanoide de, Presunção de inocência..., p. 345-347.

${ }^{263}$ Idem, p. 347-348.

${ }^{264}$ SERRANO, Nicolas Gonzáles-Cuellar, Proporcionalidad y derechos fundamentales..., p. 67-282. Também mencionam a estrutura proposta pelo autor espanhol: GuINALZ, Ricardo Donizete, Princípio da proporcionalidade e o processo penal, Dissertação de Mestrado apresentada à Faculdade de Direito da Universidade de São Paulo, 2002, p.34-41; Antonio FERnAndes, Antonio Scarance, Processo Penal Constitucional..., p. 53-55.

${ }^{265}$ SERrano, Nicolas Gonzáles-Cuellar, Proporcionalidad y derechos fundamentales..., p. 70-71 e 99.
} 
A judicialidade decorre da competência constitucional conferida ao Poder Judiciário para garantir os direitos fundamentais. É certo que certas restrições perpetradas pela administração pública dispensam esse requisito, mas em se tratando de Processo Penal ele é inafastável em virtude da natureza e da magnitude do direito individual envolvido, que é indisponível ${ }^{266}$, pois nosso direito não admite qualquer intervenção na esfera de liberdade do cidadão sem ordem judicial motivada. ${ }^{267}$ Saliente-se que este é o requisito que nos revela a relação entre a natureza dos direitos fundamentais e a solução de seus conflitos e a preemência da reserva de jurisdição.

A conclusão de que o exame dos dois níveis de incidência do postulado da proporcionalidade (verificação da inconstitucionalidade da lei e de sua correta aplicação) depende do Poder Judiciário, cujo papel no controle da justificação constitucional das normas processuais é inafastável ${ }^{268}$, é bem ilustrada pela seguinte afirmação de Maurício Zanoide de Moraes:

“Esses preceitos constitucionais determinam que o juiz penal não poderá se afastar em qualquer instante da persecução penal, de seu poder/dever de julgar todos os atos estatais constritivos da esfera de direitos fundamentais do indivíduo (p.ex., o da liberdade, de intimidade ou privacidade, ao patrimônio, além de todos os direitos fundamentais de cunho processual penal). Assim, o julgador deverá analisar os fatos e o direito, interpretando-os e aplicando-os, em cada instante da persecução, não apenas no momento da decisão do mérito da causa. "269

A motivação é condição de validade, tanto da atividade administrativa quanto da jurisdicional. Mediante a exposição de motivos, pode-se aferir se os demais requisitos impostos foram atendidos, sendo uma forma de fiscalizar sua observância. Está

\footnotetext{
${ }^{266}$ SERRANO, Nicolas Gonzáles-Cuellar, Proporcionalidad y derechos fundamentales..., p. 109-110.

${ }^{267}$ Moraes, Maurício Zanoide de, Presunção de inocência..., p. 349.

${ }^{268}$ Idem, p. 354.

${ }^{269}$ Idem, p. 354-355.
} 
relacionada, portanto, à noção de controle das arbitrariedades dos órgãos judiciais tendo em vista a imperiosidade da correta aplicação do direito. ${ }^{270}$

Por fim, cumpre analisar detalhadamente os requisitos intrínsecos do postulado da proporcionalidade, que constituem seu mérito, pois nos propusemos a fazer uma análise completa do instituto. São eles os elementos ou "subprincípios" mencionados pelos demais autores: adequação ou idoneidade, necessidade e proporcionalidade em sentido estrito. ${ }^{271}$ Contudo, não se pode perder de vista que o item essencial que nos cabia mencionar neste tópico era o requisito da judicialidade, o qual relaciona à exposição acerca dos direitos fundamentais com a reserva de jurisdição.

A adequação (Geeingnetheit) postula que a medida adotada seja capaz de realizar o fim almejado. Para aferir sua presença, deve-se fazer um juízo de pertinência. Se após tal exame a restrição revelar-se manifestamente inapta a atingir o resultado pretendido, deverá ser considerada inconstitucional. ${ }^{272}$ Humberto Ávila aponta que a relação de aptidão pode ser analisada sob três aspectos: quantitativo, qualitativo e probabilístico. Esclarece o autor:

"Em termos quantitativos, um meio pode promover menos, igualmente ou mais o fim do que outro meio. Em termos qualitativos, um meio pode promover pior, igualmente ou melhor ofim do que outro meio. E em termos probabilísticos, um meio pode promover com menos, igual ou mais certeza o fim do que outro meio". 273

\footnotetext{
${ }^{270}$ SerRano, Nicolas Gonzáles-Cuellar, Proporcionalidad y derechos fundamentales..., p. 141. MoRAES, Maurício Zanoide de, Presunção de inocência..., p. 356.

${ }^{271}$ Dimitri Dimoulis e Leonardo Martins afirmam que o exame da proporcionalidade é apresentado" como processo que tem, sucessivamente, natureza classificatória (adequação), eliminatória (necessidade) e axiológica (proporcionalidade em sentido estrito). Ver Dimoulis, Dimitri e MARTINS, Leonardo ,Teoria Geral dos Direitos Fundamentais..., p. 183.

${ }^{272}$ GuInalz, Ricardo Donizete, Princípio da proporcionalidade..., p. 35; Fernandes, Antonio Scarance, Processo Penal Constitucional..., p. 54; CANOTILHO, José Joaquim Gomes, Direito constitucional e teoria da constituição..., p. 269-270; BARRos, Suzana de Toledo, O princípio da proporcionalidade..., p. 78-80; ÁVILA, Humberto, Teoria dos princípios..., p. 116; SERRANO, Nicolas Gonzáles-Cuellar, Proporcionalidad y derechos fundamentales..., p. 154.

${ }^{273}$ ÁvILA, Humberto, Teoria dos princípios..., p. 117. Nicolas Gonzalez-Cuellar Serrano também aponta três aspectos a serem analisados, incluindo a adequação quantitativa e a qualitativa. Mas ao invés de mencionar o aspecto da certeza, menciona a adequação subjetiva, segundo a qual a medida deve ser dirigida a um indivíduo sobre o qual incidam circunstâncias exigíveis para ser atuada. Cf. SERRANO, Nicolas Gonzáles-
} 
A necessidade (Eforderlichkeit) refere-se à indispensabilidade da medida em tela. Decorre do direito do cidadão à intervenção mínima em seus interesses, isto é, seu prejuízo deve ser o menor possível. Se houver outra medida menos gravosa que promova igualmente o fim colimado, não haverá necessidade. Assim, pode-se concluir que a necessidade pressupõe a adequação da medida pois a aptidão para promover o fim visado é indispensável para que a medida mostre-se necessária. ${ }^{274}$

Nicolas Gonzalez-Cuellar Serrano expõe as notas essenciais deste requisito:

“... a) el principio de intervención mínima es um principio constitucional; b) es um principio comparativo; c) tiende a la optimización del grado de eficacia de los derechos individuales limitados". 275

Por outro lado, Canotilho aborda os quatro aspectos importantes da necessidade: o material dita a menor limitação possível aos direitos fundamentais; o espacial postula que o âmbito de intervenção deve ser limitado; o temporal delimita o tempo da intervenção; e o pessoal exige a limitação do sujeitos submetidos à medida. ${ }^{276}$

Observe-se que a subsidiariedade das medidas restritivas de direitos fundamentais advém, substancialmente, deste requisito. Isso porque é ele que determina que a medida só será levada a cabo em último caso, sendo estritamente necessária à consecução da finalidade pretendida.

Cuellar, Proporcionalidad y derechos fundamentales..., p. 160, 172 e 180. Na mesma linha, FERNANDES, Antonio Scarance, Processo Penal Constitucional..., p. 54.

${ }^{274}$ GuInAlZ, Ricardo Donizete, Princípio da proporcionalidade..., p. 36; FERNANDES, Antonio Scarance, Processo Penal Constitucional..., p. 54; CANOTILHO, José Joaquim Gomes, Direito constitucional e teoria da constituição..., p. 270; BARRos, Suzana de Toledo, O princípio da proporcionalidade..., p. 81-84; ÁvILA, Humberto, Teoria dos princípios..., p. 122.

${ }^{275}$ SERrANO, Nicolas Gonzáles-Cuellar, Proporcionalidad y derechos fundamentales..., p. 189.

${ }^{276}$ CANOTILHo, José Joaquim Gomes, Direito constitucional e teoria da constituição..., p. 270. 
Alguns autores encerram o exame da proporcionalidade neste ponto, quando a medida que restringe direito fundamental for constitucionalmente justificável se, além de adequada para atingir o objetivo proposto, não houver outra medida que seja tão eficiente e que traga menos restrição ao direito atingido. ${ }^{277}$ Nesse sentido, Dimitri Dimoulis e Leonardo Martins afirmam que o subcritério da necessidade do meio escolhido e utilizado é decisivo, pois é ele que permite definir se o meio é proporcional ao propósito perseguido. $^{278}$

Mas a maior parte deles opta por um exame final: a existência da proporcionalidade em sentido estrito (Verhältnismässigkeit). O nó górdio da análise deste requisito reside no sopesamento, na ponderação dos valores envolvidos. Por esta razão, é também chamado de princípio da justa medida. ${ }^{279}$ Humberto Ávila esclarece o objetivo deste requisito ao afirmar que:

"O exame da proporcionalidade em sentido estrito exige a comparação entre a importância da realização do fim e a intensidade da restrição aos direitos fundamentais. A pergunta que deve ser formulada é a seguinte (...) As vantagens causadas pela promoção do fim são proporcionais às desvantagens causadas pela adoção do meio? ",280

A crítica que se faz a este sub-princípio é o excesso de subjetividade que implicaria e da discricionariedade que colocaria nas mãos do juiz. ${ }^{281}$ No entanto, esta observação não é plausível uma vez que o exame da necessidade pode exigir muito mais valorações no

\footnotetext{
${ }^{277}$ Silva, Virgílio Afonso da, Direitos Fundamentais..., p. 174.

${ }^{278}$ Dimoulis, Dimitri e MARTINS, Leonardo, Teoria Geral dos Direitos Fundamentais...,. 214.

${ }^{279}$ GuINAlZ, Ricardo Donizete, Princípio da proporcionalidade..., p. 39; FERNANDES, Antonio Scarance, Processo Penal Constitucional..., p. 54; CANOTILHO, José Joaquim Gomes, Direito constitucional e teoria da constituição..., p. 270; BARROS, Suzana de Toledo, O princípio da proporcionalidade..., p. 85; SERRANO, Nicolas Gonzáles-Cuellar, Proporcionalidad y derechos fundamentales..., p. 225.

${ }^{280}$ ÁvILA, Humberto, Teoria dos princípios..., p. 124.

281 É oportuna a transcrição de trecho da obra de Dimitri Dimoulis e Leonardo Martins: “ $A$ proporcionalidade stricto sensu é uma construção irracional, dada a impossibilidade jurídica de quantificar e comparar os direitos fundamentais, decidindo qual possui maior 'peso' no caso concreto." Ver DIMOULIS, Dimitri e MARTINS, Leonardo, Teoria Geral dos Direitos Fundamentais..., p. 229.
} 
caso concreto. A objetividade será maior na medida em que forem adotados padrões de diálogo intersubjetivo que proporcionem um maior controle da atitivade jurisdicional, o que deve ser aplicado aos juízes como um todo, no exercício de todas as suas funções. ${ }^{282}$

\subsubsection{CONCLUSÕES PARCIAIS}

Demonstramos, com a apresentação das teorias relacionadas aos direitos fundamentais e sua influência na escolha da forma de solução dos conflitos de interesses, que o ideal é adotar a idéia de conteúdo essencial relativo dos direitos fundamentais, a qual se relaciona diretamente com o postulado da proporcionalidade. Este, por conseguinte, apresenta como um de seus requisitos a judicialidade, exigindo a intervenção do Poder Judiciário para proceder à avaliação do caso concreto de acordo com os ditames constitucionais.

Sempre tendo em vista o objetivo deste trabalho, que é definir as situações em que a manifestação do Poder Judiciário é necessária para a perpetração de uma restrição de direito fundamental, a qual podemos chamar de intervenção nos termos da teoria ora exposta, cumpre apresentar a observação de Denilson Feitoza Pacheco, para quem:

“...se considerarmos um meio probatório, uma medida cautelar, pessoa ou um ato processual (por exemplo, respectivamente uma busca domiciliar, uma prisão temporária e a propositura de uma ação penal) como uma intervenção em um direito fundamental, isso acarretará a aplicação de garantias de direitos fundamentais, entre eles a aplicação do princípio da proporcionalidade, na qual se

${ }^{282}$ SILVA, Virgílio Afonso da, Direitos Fundamentais..., p. 178. 
deve justificar a idoneidade, necessidade e proporcionalidade stricto sensu da medida interventiva. "283

Neste ponto, não podemos deixar de chamar atenção para o fato de que os juízes só são os órgãos adequados para efetuar a avaliação necessária à proteção do conteúdo essencial, bem como à aplicação do postulado da proporcionalidade, em virtude de todas as características descritas no item 3.2.1., até porque a judicialidade é requisito extrínseco do postulado.

Assim, só nos resta relacionar a tese aqui defendida com o mandamento do devido processo legal insculpido no inciso LIV do artigo $5^{\circ}$ da Constituição Federal do Brasil.

\subsubsection{O DEVIDO PROCESSO LEGAL E A IMPERIOSIDADE DA} MANIFESTAÇÃO JUDICIAL

A cláusula do devido processo legal originou-se no artigo 39 da Magna Carta de 1215, que determinava que os direitos à vida, à liberdade e à propriedade só poderiam ser suprimidos pela lei da terra ("law of the land" ou "per legem terrae" como constava no original). ${ }^{284} \mathrm{~A}$ intenção era limitar o poder punitivo estatal em face dos direitos e garantias individuais. ${ }^{285}$ As declarações inglesas posteriores, como a "Petition of Rights", de 1628, continuaram a fazer menção à cláusula, mas sua denominação já havia sido alterada para "due process of law". ${ }^{286}$

\footnotetext{
${ }^{283}$ PACHECO, Denilson Feitoza, O princípio da proporcionalidade no direito processual penal brasileiro, Rio de Janeiro, Editora Lumen Juris, 2007, p. 145.

${ }^{284}$ GONÇALVES, João Batista $O$ devido processo legal e o pacto de São José da Costa Rica, Tese de doutorado apresentada à Faculdade de Direito da Universidade de São Paulo, 1999, p. 30; FernandeS, Antonio Scarance, Processo Penal Constitucional..., p.. 47; Franco, Alberto Silva e Moraes, Maurício Zanoide de, Cap. I - Devido Processo Legal..., p. 240.

${ }^{285}$ Franco, Alberto Silva e MorAES, Maurício Zanoide de, Cap. I - Devido Processo Legal..., p. 240.

${ }^{286}$ GONÇALVES, João Batista $O$ devido processo legal..., p. 31; FRANCO, Alberto Silva e MORAES, Maurício Zanoide de, Cap. I-Devido Processo Legal..., p. 240.
} 
Nos EUA, o "due process of law” foi consagrado nas Emendas $5^{\mathrm{a}}$ e $14^{\mathrm{a}}$, a partir das quais se desenvolveu, ganhou novos significados em virtude da atividade jurisprudencial e atingiu sua maturidade doutrinária. Com o passar do tempo, os demais países também passaram a fazer essa previsão em seus textos constitucionais. ${ }^{287}$

Num primeiro momento, a cláusula restringia-se ao âmbito processual, fixando a forma e o procedimento que deveriam ser observados para que não houvesse prejuízo aos direitos fundamentais. Trata-se do dever de executar as leis da melhor maneira possível. A exigência de um procedimento regular e justo, no início, era adstrita ao Processo Penal, mas depois se alastrou para o âmbito cível e administrativo. ${ }^{288}$

Já na segunda metade do século XIX, a Suprema Corte americana passou a analisar a constitucionalidade das leis e a legalidade dos atos administrativos com base na idéia de razoabilidade, levando em conta os valores da liberdade e da riqueza. O sistema casuístico da common law permitiu esse controle fundado no devido processo legal e deu origem ao "substantive due process of law'.289

Hoje, podemos afirmar a existência de duas vertentes do devido processo legal. Pela vertente formal, a lei deve ser aplicada judicialmente mediante um instrumento hábil à sua interpretação e realização, isto é, o processo. Além disso, este deve ser justo, proporcionando às partes a oportunidade de se manifestar, de se defender, de tomar ciência dos atos processuais, entre outras garantias fundamentais. ${ }^{290}$

A acepção material do devido processo legal, comumente chamada de "substantive due process of law", dita que tanto as leis quanto as decisões judiciais devem ser

\footnotetext{
${ }^{287}$ GONÇALVES, João Batista $O$ devido processo legal..., p. 33-34; FeRnANDES, Antonio Scarance, Processo Penal Constitucional..., p. 47.

${ }^{288}$ GONÇALVES, João Batista $O$ devido processo legal..., p 32 e 35; Fernandes, Antonio Scarance, Processo Penal Constitucional..., p. 47; Franco, Alberto Silva e Moraes, Maurício Zanoide de, Cap. I - Devido Processo Legal..., p. 240.

${ }^{289}$ GONÇALVES, João Batista $O$ devido processo legal..., p 40-44; Fernandes, Antonio Scarance, Processo Penal Constitucional..., p. 47; Franco, Alberto Silva e Moraes, Maurício Zanoide de, Cap. I - Devido Processo Legal..., p. 240.

${ }^{290}$ GONÇALVES, João Batista $O$ devido processo legal..., p. 81.
} 
consoantes com os princípios constitucionais. ${ }^{291}$ As exigências das leis não podem ser desarrazoadas, incompatíveis com a ordem jurídica.

Feitas essas considerações sobre a evolução do conteúdo do devido processo legal, urge relacionar este princípio com a necessidade de intervenção judiciária na seara das restrições a direitos fundamentais.

Já afirmamos reiteradas vezes no decorrer deste trabalho que a reserva de jurisdição aplica-se aos casos em que há conflitos entre direitos fundamentais ou bens constitucionalmente protegidos, de maneira que o Poder Judiciário é o único órgão apto a solucionar esta colisão e efetuar uma restrição a um desses interesses em virtude da independência da função jurisdicional e a natureza dos direitos fundamentais como fatores justificantes de tal assertiva.

Contudo, temos, ainda, um dispositivo constitucional que vem reforçar essa tese. Com efeito, reza o inciso LIV do artigo $5^{\circ}$ da Constituição:

"LIV - ninguém será privado da liberdade ou de seus bens sem o devido processo legal;"

Ora, a liberdade, em uma acepção ampla, é entendida como qualquer direito individual conferido aos cidadãos em face do Estado ${ }^{292}$. Sendo assim, é imperiosa a observância do devido processo legal quando se pretende limitar a aplicação de qualquer direito fundamental de primeira geração, os quais costumam ser atingidos pela atividade da

291 GonÇALVES, João Batista $O$ devido processo legal..., p 40-44; FERnANDES, Antonio Scarance, Processo Penal Constitucional..., p. 81 e 86; FrAnCo, Alberto Silva e MorAES, Maurício Zanoide de, Cap. I-Devido Processo Legal..., p. 240.

${ }^{292}$ Os direitos individuais ou direitos civis, conhecidos como direitos fundamentais de primeira geração também são denominados de liberdades públicas. Surgiram nas Declarações de Direito do século XVIII como reação ao absolutismo, e tinham por objetivo primordial impedir que o Estado interferisse excessivamente na vida dos cidadãos. Ver CANOTILHO, José Joaquim Gomes, Direito constitucional e teoria da constituição..., p. 377 e 395. 
persecução penal. Danielle Souza de Andrade e Silva sintetiza a idéia e de forma bastante elucidativa:

"O processo judicial consubstancia-se, portanto, em uma garantia conferida pelos diplomas internacionais e pela Carta Magna aos membros da coletividade, para a consecução dos direitos denominados fundamentais mediante a efetivação do direito ao processo, com a imprescindivel concretização de todos os seus consectários e em um prazo razoável. "293

Essa afirmação é um convite ao raciocínio. Se o processo é uma garantia para a concretização dos direitos fundamentais e se é por meio dele que o juiz exerce a atividade jurisdicional e atua como representante da soberania estatal, temos que, ao assegurar o devido processo legal para casos de restrição à liberdade, a Constituição está exigindo a participação da figura do magistrado. Em outras palavras, a decisão judicial emerge como condição inafastável para a limitação de um direito fundamental. ${ }^{294}$

Ademais, como se afirma largamente na doutrina, o devido processo legal é fonte inesgotável de garantias e princípios constitucionais, de modo que sua aplicação acarreta a necessidade de se observarem diversos outros princípios tais como a ampla defesa, o contraditório, a motivação e a publicidade. ${ }^{295}$ Além disso, o desenvolvimento dessa cláusula possibilitou o surgimento de sua acepção material, que controla a compatibilidade do conteúdo das leis com os valores constitucionais.

\footnotetext{
${ }^{293}$ SiLVA, Danielle Souza de Andrade e, A atuação do juiz no processo penal acusatório - Incongruências no sistema brasileiro em decorrência do modelo constitucional de 1988, Porto Alegre, Sergio Antonio Fabris Editor, 2005, p. 75.

${ }^{294}$ Maurício Zanoide de Moraes afirma que "não se admite qualquer intervenção estatal na esfera de liberdade do cidadão sem ordem judicial motivada", Cf MORAEs, Maurício Zanoide de, Presunção de inocência..., p. 349.

${ }^{295}$ Antonio Scarance Fernandes refere-se ao devido processo legal como garantia inominada, por dar assento a outras garantias não expressas. V. FERNANDES, Antonio Scarance, Processo Penal Constitucional..., $5^{\mathrm{a}} \mathrm{p}$. 48. Ver também SILVA, Danielle Souza de Andrade e, A atuação do juiz no processo penal acusatório..., p. 75
} 
Em decorrência da aplicação do devido processo legal e da exigência de imparcialidade na determinação de restrição a direitos fundamentais, esta só pode ser perpetrada no decorrer de uma investigação ou de um processo criminal. Como bem disseram Alberto Silva Franco e Maurício Zanoide de Moraes, a cláusula do devido processo legal não desponta apenas na fase judicial, mas no âmbito de qualquer um dos três poderes, na medida em que funciona como um limitador do poder estatal. ${ }^{296}$

E por força do artigo 93, inciso IX de nossa Constituição, essa decisão deve ser motivada adequadamente, pois o juiz não está autorizado a decidir de qualquer maneira, devendo justificar suas opções e obedecer aos preceitos constitucionais, o que permitirá a verificação da correta aplicação do direito, bem como constatar as razões que o levaram a autorizar eventual medida restritiva. ${ }^{297}$

O Poder Judiciário é o único que possui competência para apreciar o cabimento de medidas restritivas de direito nesses termos, protegendo os direitos fundamentais e relativizando-os em face de outros bens constitucionalmente protegidos, como o interesse da investigação. Assim, o Judiciário é o único órgão dotado de imparcialidade para tal análise, pois outros órgãos como o Ministério Público e as Comissões Parlamentares de Inquérito têm interesse direto no resultado da empreitada, não sendo capazes de efetuar a devida ponderação dos princípios envolvidos.

Sendo a determinação judicial a única forma de se efetuar uma intervenção em direito fundamental com total observância aos ditames do devido processo legal, podemos afirmar a existência de uma reserva de jurisdição absoluta, o que impediria qualquer outro

\footnotetext{
${ }^{296}$ Avolio, Luiz Francisco Torquato, Provas Ilícitas: interceptações telefônicas, ambientais e gravações clandestinas, $3^{\text {a }}$ ed. rev., ampl. e atual. em face das leis 9.296/96 e 10.217/2001 e da jurisprudência, São Paulo, Editora Revista dos Tribunais, 2003, p. 211; FRANCO, Alberto Silva e MORAES, Maurício Zanoide de, Cap. I - Devido Processo Legal..., p. 240. Na jurisprudência, esse entendimento é raro. O voto vencido do ministro Celso de Mello no MS 21.729-4 nega às CPIs o poder de determinar a quebra do sigilo financeiro. Cf. STF, MS 21.729-4, DF, Rel., Ministro Marco Aurélio, Tribunal Pleno, DJ 10.10.2001.

${ }^{297}$ Moraes, Maurício Zanoide de, Presunção de inocência..., p. 355-356. Nesse sentido, Ferrajoli considera a motivação uma garantia de segundo grau, por ser uma garantia das demais garantias primárias, podendo-se, por meio dela, ter certeza acerca do atendimento das demais. Diz o autor: "... a motivação permite a fundação e o controle das decisões seja de direito, por violação de lei ou defeito de interpretação ou subsunção, seja de fato, por defeito ou insuficiência de provas ou por explicação inadequada do nexo entre convencimento e provas. (...) Ao mesmo tempo, enquanto assegura o controle da legalidade e do nexo entre convencimento $e$ provas, a motivação carrega também o valor 'endoprocessual' de garantia de defesa e o valor 'extraprocessual' de garantia de publicidade. E pode ser, portanto, considerado o principal parâmetro tanto da legitimação interna ou jurídica quanto da externa ou democrática da função judiciária." Cf. FERRAJOLI, Luigi, Direito e Razão..., p. 573-574.
} 
órgão de determinar a violação de tal direito fundamental. Voltamos, portanto, a nossa premissa inicial, de que o devido processo legal seria um dos fatores justificantes da necessidade de se aplicar a reserva de jurisdição.

Alberto Silva Franco e Maurício Zanoide de Moraes asseveram expressamente que a reserva de jurisdição pode ser extraída do conteúdo do devido processo legal, o qual se apresenta como uma "cláusula de segurança" do sistema jurídico para a consecução de um processo justo. ${ }^{298}$

Tal afirmação nos leva a crer que, nos casos em que se pretende restringir direitos fundamentais, somente ao Poder Judiciário compete a apreciação do cabimento de tal restrição. Apenas os magistrados poderão avaliar se a situação concreta que se apresenta enquadra-se numa hipótese legal de violação ou, no caso de o Legislativo não ter sido capaz de prever toda a casuística futura, somente um órgão judicante poderá sopesar os bens jurídicos envolvidos e decidir pelo afastamento ou não do direito fundamental em jogo.

\subsection{CRITÉRIOS PARA ELEGER OS CASOS DE RESERVA DE JURISDIÇÃO ABSOLUTA IMPLÍCITAS}

No item 3.2 supra, optamos por fazer um retrocesso na teoria da reserva de jurisdição para demonstrar as razões pelas quais é necessário haver no sistema um núcleo de atividades reservadas a um determinado órgão, explicando as características que fazem do Judiciário o órgão adequado para desenvolver a função de resolução de conflitos de maneira definitiva, sobretudo nos casos especiais em que os interesses envolvidos são de extrema relevância, nos termos da teoria da justeza funcional.

\footnotetext{
${ }^{298}$ FrANCO, Alberto Silva e MORAES, Maurício Zanoide de, Cap. I- Devido Processo Legal..., p. 252 e 332. Maurício Zanoide de Moraes repete a afirmação em sua recente tese de livre-docência. Cf. MORAES, Maurício Zanoide de, Presunção de inocência..., p. 355.
} 
Tratamos das características de independência, imparcialidade e isenção do Poder Judiciário para demonstrar essa adequação existente entre órgão e função a ele atribuída, de modo a justificar a impossibilidade de outros órgãos exercerem determinadas tarefas; discorremos acerca da origem dos direitos fundamentais e das formas de resolução de conflitos entre eles para entender o critério que nos levará à determinação dos casos submetidos à reserva de jurisdição absoluta; e, por fim, abordamos a relação entre a garantia do devido processo legal e as medidas restritivas de direitos fundamentais, reiterando os argumentos esposados anteriormente.

Estabelecidas essas premissas, devemos voltar à tarefa iniciada no item 3.1.2, de definir as hipóteses em que a reserva absoluta de jurisdição deve ser observada, afastando a intervenção de qualquer outro Poder do Estado Democrático de Direito, mas agora, a empreitada será levada a cabo no âmbito do Processo Penal, que é o objeto de nosso estudo.

Naquela oportunidade, afirmamos que a reserva de jurisdição absoluta poderia ser constitucional, quando prevista expressamente no texto supremo; legal, quando positivada em lei ordinária; ou implícita, quando as circunstâncias levassem à imperiosidade da decisão judicial para a resolução do caso. Repise-se que para podermos definir os parâmetros das hipóteses implícitas, tivemos que investigar as razões pelas quais as reservas de jurisdição positivadas foram criadas, de modo a poder estender a mesma lógica às demais situações.

A lógica encontrada nos mostrou que o Judiciário é a instituição agraciada com a função de decidir sobre conflitos que envolvam restrições de direitos fundamentais, pois possui as características da independência, imparcialidade e isenção, porquanto só um órgão separado dos demais e livre de influências, sejam elas de partes processuais, sejam de valores sociais ou pessoais, é que tem condições de tomar decisões justas sobre temas especiais.

Extraímos daí o primeiro critério a ser analisado para avaliarmos se há a necessidade de submeter a situação à reserva de jurisdição: haver um conflito de interesses, pois o ato só será exclusivamente jurisdicional se exigir a resolução de um conflito de interesses de maneira definitiva. Os atributos do Poder Judiciário servem mais para 
justificar a questão da adequação do órgão à função, relativas ao modelo de justeza funcional, do que exatamente para indicar os casos que devem ser submetidos ao monopólio da primeira palavra.

A definição dos casos específicos em que sua intervenção é necessária depende mais de outro fator justificante da reserva de jurisdição, tratado no item 3.2.2., a própria natureza dos direitos fundamentais. A análise de sua essência nos revelou que, ao adotarmos a idéia de conteúdo essencial relativo dos direitos fundamentais temos como corolário inafastável a aplicação do postulado da proporcionalidade para a resolução dos conflitos entre eles, uma vez que possuem natureza principiológica. Note-se que os bens constitucionalmente protegidos, ainda que não possam ser enquadrados como direitos fundamentais, também exigem a utilização da proporcionalidade para a resolução dos conflitos em que estiverem envolvidos, já que possuem natureza de princípio. ${ }^{299}$

Considerando que a proporcionalidade tem como um de seus requisitos a judicialidade, exigindo a intervenção do Poder Judiciário para proceder à avaliação do caso concreto de acordo com os ditames constitucionais, temos que efetuar um raciocínio inverso para concluir que a reserva de jurisdição será imposta toda vez que houver um conflito entre direitos fundamentais ou bens constitucionalmente protegidos, porquanto sua natureza e a idéia de que seu conteúdo essencial é relativo nos levam à aplicação do postulado da proporcionalidade, o qual tem como um de seus requisitos a judicialidade.

Encontrado o segundo critério procurado, que consiste na qualificação dos conflitos mencionados no primeiro item. Temos, assim, que a intervenção judicial é indispensável e inafastável quando o conflito apresentado abarcar direitos fundamentais e outros bens constitucionalmente protegidos, expressões de um interesse público primário, o qual tem em vista o bem comum da sociedade, pela necessária aplicação do postulado da proporcionalidade.

Por fim, devemos fazer a análise às avessas do último fator justificante da reserva de jursidição por nós apresentado, o devido processo legal. O inciso LIV do artigo $5^{\circ}$ da

\footnotetext{
${ }^{299} \mathrm{O}$ interesse do Estado em punir aqueles que cometem crimes não pode ser classificado como um direito fundamental, mas nem por isso deixa de receber proteção do ordenamento jurídico. É um interesse tutelado pela ordem constitucional que traz em si a idéia de que aqueles que violam as leis do Estado devem ser punidos.
} 
Constituição, transcrito no item 3.2.3 supra, exige a aplicação do devido processo legal para todos os casos em que houver restrição à liberdade. Como já dito, a liberdade aqui deve ser interpretada como qualquer direito de primeira geração.

Pois bem. O processo é o meio pelo qual o magistrado exerce sua função jurisdicional, sendo um mecanismo que proporciona a observância de diversas garantias. Outrossim, o texto constitucional assegura que as restrições à liberdade só serão feitas no bojo de um processo, o que significa que apenas o juiz poderá executar tal tarefa. Portanto, se adotarmos a interpretação da liberdade exposta acima, resta-nos concluir que limitações a quaisquer direitos individuais só poderão ser efetuadas por membros do Poder Judiciário.

Isso significa que a restrição a direitos constitucionalmente protegidos, ou intervenção como afirmamos no item 3.2.2, é função exclusivamente jurisdicional, o que nos possibilita captar o último critério para definirmos os casos que, apesar de não previstos na Constituição ou lei ordinária, devem ser submetido à reserva de jurisdição. A solução para os conflitos de interesses relevantes, envolvendo direitos fundamentais ou outros bens constitucionalmente protegidos, deve exigir a limitação de um deles.

Portanto, temos que os casos de reserva de jurisdição implícita serão eleitos sempre que se constatar uma situação que ensejar a limitação de um direito fundamental ou outro bem constitucionalmente protegido, em decorrência de um conflito de interesses que só pode ser solucionado de forma definitiva pelo Poder Judiciário.

Cumpre, no próximo capítulo, analisar quais serão essas hipóteses dentro do Processo Penal. Para tanto, analisaremos medidas restritivas de direitos fundamentais, mormente meios de prova e de obtenção de prova, que ensejam a restrição de direitos fundamentais em prol do interesse estatal da investigação e punição daqueles que praticam crimes para avaliar se exigem a aplicação do monopólio da primeira palavra para sua efetivação. Não poderemos deixar de lado, entretanto, aquelas medidas em que a reserva de jurisdição é explícita, o que será apontado e devidamente explicado à luz de tudo o que já foi exposto neste trabalho. Todo o esforço se justifica para que, ao final, possamos encontrar o verdadeiro alcance dos poderes investigatórios das Comissões Parlamentares de Inquérito. 


\section{A RESERVA DE JURISDIÇÃO NO PROCESSO PENAL}

Tomando como premissa básica a idéia de que as restrições de direitos são inevitáveis no exercício da persecução penal, até pela necessidade de se atingir os resultados almejados, ou seja, pela necessidade de se possuir um Processo Penal eficiente, mostraremos que elas devem ser perpetradas da forma mais garantista possível sendo que a exigência de decisão judicial para seu emprego é o requisito que mais se destaca.

Assim, analisaremos algumas medidas restritivas de direito, ressaltando suas características que tornam imprescindível sua submissão à cláusula de reserva de jurisdição.

\subsection{PROCESSO PENAL: FINALIDADES E A BUSCA DA VERDADE}

\subsubsection{ESCOPOS DO PROCESSO PENAL}

O Processo Penal é o meio pelo qual o Estado efetiva seu direito de punir aqueles que atentam contra bens relevantes da sociedade, isto é, exerce o chamado ius puniendi, tendo em vista a proibição da autotutela. Observe-se, contudo, que ao interesse do Estado de punir o culpado contrapõe-se o interesse do réu de preservar seu ius libertatis. ${ }^{300}$ Sendo ambos os interesses indisponíveis, sua conciliação torna-se complexa. Conforme preleciona Ada Pellegrini Grinover:

\footnotetext{
300 Tourinho Filho, Fernando da Costa, Manual de processo penal..., p. 5-9. No que tange a essa contraposição de interesses, o autor defende que, reconhecendo não ser uma posição unânime, existe lide no processo penal, pois a pretensão de punir deve ser obrigatoriamente resistida pelo direito de liberdade do réu. Entretanto, está consagrado o entendimento de que não há lide no processo penal, porquanto não há dois interesses em conflito, mas apenas o interesse de se fazer justiça. Desta forma, Antonio Carlos de Araújo Cintra, Ada Pellegrini Grinover e Cândido Rangel Dinamarco falam em controvérsia penal ao invés de lide penal. Cf. Cintra, Antonio Carlos de Araújo, Grinover, Ada Pellegrini e Dinamarco, Teoria Geral do Processo..., p. 257-258.
} 
"O problema nevrálgico do processo penal é o das relações entre o Estado e o indivíduo, devendo encontrar-se em sua esfera a solução do conflito entre as exigências comunitárias da repressão do crime e a proteção da esfera das liberdades fundamentais". 301

Já houve época em que o ius puniendi estatal era privilegiado em face dos direitos e garantias individuais, em decorrência da orientação política adotada, por exemplo, pelo Estado Novo. Atualmente, com a instituição de um Estado Democrático de Direito pela Constituição de 1988 , a situação foi alterada. ${ }^{302}$

O Processo Penal voltou a ter dois objetivos, visando tanto à tutela da liberdade jurídica do indivíduo quanto à garantia da sociedade contra a prática de atos penalmente relevantes. ${ }^{303}$ Em suma, o interesse do Estado é realizar a justiça penal, a qual pode se concretizar tanto por meio da aplicação da pena a um culpado, quanto pela absolvição de um inocente. Isso significa que não se pode mais admitir uma busca incontrolada da verdade como outrora, embora a análise cautelosa dos fatos deva ser objeto de atenção. ${ }^{304}$ O processo deve atentar a uma escrupulosa regra moral. ${ }^{305}$

Antonio Scarance Fernandes aborda o tema sob outra perspectiva. Assevera o autor que ao processo criminal interessam dois direitos fundamentais do indivíduo previstos no rol do artigo $5^{\circ}$ da Constituição: o direito à liberdade e o direito à segurança, e liga esta constatação a sua linha de pesquisa, que estuda a relação entre eficiência e garantismo no

\footnotetext{
${ }^{301}$ GRINOVER, Ada Pellegrini, Liberdades públicas e processo penal: as interceptações telefônicas, $2^{\mathrm{a}} \mathrm{ed}$. atual., São Paulo, Editora Revista dos Tribunais, 1982, p. 16.

302 BARros, Marco Antonio, de A busca da verdade no processo penal, São Paulo, Editora Revista dos Tribunais, 2002, p. 84-90.

${ }^{303}$ Essa dupla finalidade do processo penal é apresentada por Rogério Lauria Tucci em Direitos e garantias individuais no processo penal brasileiro, São Paulo, Editora Saraiva, 1993, p. 23. Cleunice Pitombo acrescenta a esses escopos a reparação do dano decorrente da infração penal. Ver PITOMBO, Cleunice A. Valentim Bastos, Processo penal: prova e verdade, Tese de doutorado apresentada na Faculdade de Direito da Universidade de São Paulo, São Paulo, 2003, p. 2.

304 ZILLI, Marcos Alexandre Coelho, A iniciativa instrutória do juiz no processo penal, São Paulo, Editora Revista dos Tribunais, 2003, p. 112.

305 Grinover, Ada Pellegrini, Fernandes, Antonio Scarance, Gomes FILHO, Antonio Magalhães, As nulidades no processo penal, $10^{\mathrm{a}}$ ed. rev e atual, São Paulo, Editora Revista dos Tribunais, 2007, p. 155.
} 
Processo Penal. Assim, para ele, o procedimento deve visar à obtenção de um resultado justo, proporcionando a efetivação concomitante dos direitos à segurança, com a punição dos infratores, e à liberdade dos indivíduos, assegurando-se o pleno exercício da defesa aos acusados, tudo de uma forma equilibrada. Aí está a noção de eficiência. ${ }^{306} \mathrm{O}$ seguinte trecho da obra estudada é muito esclarecedor:

“Em outros termos, o direito ao procedimento processual penal consiste em direito a um sistema de princípios e regras que, para alcançar um resultado justo, faça atuar as normas do direito repressivo necessárias para a concretização do direito fundamental à segurança, e assegure ao acusado todos os mecanismos essenciais para a defesa de sua liberdade. De maneira resumida, um sistema que assegure eficiência com garantismo, valores fundamentais do processo penal moderno. „307

No mesmo sentido, Gilberto Thums propõe uma síntese, com fulcro no pensamento de Ferrajoli, afirmando que as expressões garantias e eficiência confundem-se, porquanto "devem traduzir a menor intervenção penal possível e a máxima realização da proteção dos direitos fundamentais", 308

Se, genericamente, a eficiência é a capacidade de algo produzir um determinado efeito, no Processo Penal, ela se expressa mediante a capacidade de um ato,

\footnotetext{
${ }^{306}$ FERNANDES, Antonio Scarance, Reflexões sobre as noções de eficiência e de garantismo no processo penal, in FERnAndes, Antonio Scarance, AlmeIDA, José Raul Gavião de e MoRAES Maurício Zanoide de (coord.), Sigilo no processo penal: eficiência e garantismo, São Paulo, Editora Revista dos Tribunais, 2008, p. 9 e 16; FERNANDES, Antonio Scarance, O equilíbrio na repressão ao crime organizado, in FERNANDES, Antonio Scarance, AlmeIDA, José Raul Gavião de e MorAEs Maurício Zanoide de (coord.) Crime organizado - aspectos processuais, , Crime Organizado, São Paulo, Editora Revista dos Tribunais, 2009, p. 9-10.

307 FERNANDES, Antonio Scarance, Reflexões sobre as noções de eficiência e de garantismo..., p. 10. Scarance afirma que para medir a eficiência do processo, é essencial determinar qual é a sua finalidade. Para tanto, há que se escolher uma das três correntes: a que pugna pela ênfase na defesa do acusado; a que dá enfoque para a busca da verdade e punição; e a que acredita que a finalidade do processo penal é a obtenção de um resultado justo num procedimento que assegure a ambas as partes garantias e o exercício de seus direitos. Ver. op. cit. p. 24-25.

${ }^{308}$ THUMS, Gilberto, O mito sobre a verdade e os sistemas processuais, in FAYET JR., Ney, Ensaios penais em homenagem ao Professor Alberto Rufino Rodrigues de Sousa, Porto Alegro, Ricardo Lenz, 2003, p. 338339.
} 
meio de prova ou meio de investigação gerar o efeito esperado, por exemplo, descobrir uma determinada fonte de prova, sem afrontar normas de garantia. Nesse contexto, o postulado da proporcionalidade apresenta grande utilidade, pois possibilita analisar a ocorrência de excessos da utilização de medidas que ensejam invasões a direitos fundamentais. E a decisão judicial será imprescindível para esta ponderação, podendo ser dispensada apenas nos casos em que a urgência exigir, como se dá na prisão em flagrante. $^{309}$

Diante desta dupla finalidade do Processo Penal, não se pode negar a existência de um constante conflito entre a liberdade e a segurança, o qual merece ser solucionado de uma forma equilibrada para se atingir o resultado justo preconizado pela noção de eficiência. Em havendo um conflito que envolve interesses de tamanha relevância e status constitucional, será imperiosa a intervenção judicial para sua solução, nos termos de tudo o que já foi exposto no capítulo anterior.

Para desempenhar esta tarefa, o juiz não pode abrir mão da tentativa de reconstruir os fatos com o fim de aplicar o direito da melhor forma possível. Assim, embora a busca desenfreada pela punição e verdade não integre mais a realidade processual atual, ela é elemento central de um processo eficiente. Ao solucionar conflitos, a função jurisdicional apresenta a peculiaridade de se fundar na atividade cognitiva, na busca do conhecimento. $^{310}$

Destarte, passamos a discorrer sobre os termos em que a reconstrução fática será conciliada com as garantias processuais do acusado.

\footnotetext{
309 FERNANDES, Antonio Scarance, Reflexões sobre as noções de eficiência e de garantismo..., p. 25; FERNANDES, Antonio Scarance, O equilíbrio na repressão ao crime organizado..., p. 11-12.

${ }^{310}$ Esta última frase foi inspirada na afirmação de Mauro Augusto Boccardo, em seu texto, A decidibilidade da verdade processual à luz do garantismo, in Revista Jurídica da Universidade de Franca, ano $9, \mathrm{n}^{\circ}{ }^{\circ} 17,2^{\circ}$ semestre, Franca, Editora Unifran, 2007, p. 113. Quer-se ressalvar, todavia, que o autor trata a atividade cognitiva como exclusiva à função jurisdicional, com o que não podemos concordar. Isso porque, para solucionar um conflito no âmbito administrativo, por exemplo, o Poder Executivo também deverá proceder a uma investigação dos fatos. Outrossim, um dos temas centrais desse estudo, o inquérito parlamentar, é prova cabal de que a busca da verdade e o exercício da cognição não são exclusividade do Poder Judiciário.
} 


\subsubsection{A VERDADE PROCESSUALMENTE POSSÍVEL}

A doutrina é praticamente uníssona ao afirmar que a busca da verdade não pode ser o fim do Processo Penal. ${ }^{311}$ De acordo com a assertiva de Antonio Magalhães Gomes Filho, o processo é um mecanismo importante de solução de conflitos sociais, esse é seu verdadeiro escopo, sendo o núcleo da função jurisdicional. ${ }^{312}$ Para alcançá-lo, devem ser asseguradas a justiça e a segurança. De outra maneira, a verdade seria obtida sem a observância do devido processo legal, o que seria inadmissível. ${ }^{313}$

Conquanto não seja o fim último do Processo Penal, a verdade, bem como a fixação das condições nas quais uma tese jurisdicional é verificável, é importante tanto para a teoria quanto para a prática, além de servir de parâmetro do sistema garantista. Observe-se que só se poderia prescindir da procura da verdade se fosse adotado um modelo puramente decisionista, o que vai de encontro aos anseios do garantismo, que visa à diminuição da discricionariedade nas decisões. ${ }^{314}$

Gilberto Thums expõe a relação existente entre o Processo Penal e o discurso sobre a verdade, uma vez que esta fundamenta a outorga legal de poderes ao magistrado. Mas a forma como esses poderes são conferidos, bem como a importância que será dada à verdade é o "divisor de águas entre os sistemas processuais", nos termos do autor. Para ele, temos:

\footnotetext{
${ }^{311}$ GRINOVER, Ada Pellegrini Iniciativa instrutória do juiz no processo penal acusatório, in Revista Forense, n. ${ }^{\circ} 347$, jul-set de 1999, p. 5; BARRos, Marco Antonio de, A busca da verdade no processo penal..., p. 21; PItombo, Cleunice Processo penal..., p. 6; HASSEMER, Winfried, Fundamentos del Derecho Penal, Francisco Muñoz Conde e Luis Arroyo Zapatero (trad.), Barcelona, José María Bosch, 1984, p. 190; GOMES FILHo, Antonio Magalhães, Direito à prova no processo penal, São Paulo, Editora Revista dos Tribunais, 1997, p. 51.

312 GOMES FILHO, Antonio Magalhães, Direito à prova no processo penal..., p. 51. Nesse sentido, Antonio Carlos de Araújo Cintra, Ada Pellegrini Grinover e Cândido Rangel Dinamarco afirmam que a pacificação social é o escopo magno da jurisdição. Os autores subdividem esse escopo em três categorias: sociais, políticos e jurídicos. Cf. Teoria Geral do Processo..., 2001, p. 24.

${ }_{313}$ PIтомBo, Cleunice Processo penal..., p. 24-25. A autora esclarece, ainda, que a finalidade do processo e seu fim são coisas diferentes. Aquela se refere à adequação do processo ao fim que visa, ligando-se ao conceito de procedimento. Cf. op cit., p. 25-26.

${ }^{314}$ FerRAJOLI, Luigi, Direito e Razão..., p. 49. Para o autor, o juízo penal é uma combinação entre o saber e poder. Na medida em que se diminui o conhecimento acerca dos fatos da realidade, aumenta a discricionariedade da decisão, isto é, utiliza-se o poder. Por essa razão, a busca da verdade é necessária como meio de proporcionar um processo que obedeça às garantias previstas no sistema.
} 
"De um lado, o modelo que se utiliza da verdade como instrumento de dominação e legitimação a justificar qualquer procedimento, inclusive com poderes investigatórios conferidos ao julgador; de outro lado, o sistema acusatório (garantista), que encara a verdade apenas como uma referência, um juízo de probabilidade sobre o fato, condicionando a verdade à forma de produzir-se a prova e aos instrumentos de sua valoração. O modelo acusatório não apresenta obsessão pelo termo verdade. „315

Assim, sem exacerbar sua importância, devemos dizer que a verdade buscada por meio da instrução criminal é um meio de legitimação da atividade jurisdicional. ${ }^{316}$ Nos dizeres de Magalhães, seria inconcebível uma sentença justa que não se preocupasse com a verificação correta dos fatos, o que é feito mediante a produção de provas. ${ }^{317}$ Por tal razão, diz-se que prova e verdade relacionam-se de uma maneira funcional, isto é, a função das provas é estabelecer a verdade. Outrossim, o fato de as decisões judiciais serem fundadas em provas transmite a idéia de que são válidas e, portanto, justas. ${ }^{318}$

Mas não se deve olvidar que o direito à prova não é absoluto, embora previsto constitucionalmente. Os direitos individuais não podem mais ser considerados ilimitados, uma vez que devem conviver harmoniosamente entre si. $^{319}$ Fosse o direito à prova absoluto, estar-se-ia permitindo, previamente, uma violação dos direitos à intimidade e à integridade física, por exemplo. Ora, não se pode tolerar que a verdade seja descoberta

\footnotetext{
315 THUMS, Gilberto. O mito sobre a verdade e os sistemas processuais..., p. 324-235.

${ }^{316}$ GOMES FilHo, Antonio Magalhães, Direito à prova no processo penal..., p. 54; FerRAJOLI, Luigi, Direito e Razão..., p. 65. Cumpre ressaltar que Ferrajoli acredita ser a verdade a única motivação apta a conferir legitimidade às decisões penais, mesmo que só possa ser obtida imperfeitamente.

${ }^{317}$ GOMES FILHO, Antonio Magalhães Direito à prova no processo penal..., p. 54. Marco Antonio de Barros também assevera que a aplicação correta da lei depende da descoberta da verdade, o que se faz por meio da prova. Ver BARRos, Marco Antonio de, A busca da verdade no processo penal..., p. 21 e 106.

318 GOMES FILHO, Antonio Magalhães, Direito à prova no processo penal..., p. 42-43. Conforme assertiva de Marco Antonio de Barros, a verdade é elemento essencial para a produção da Justiça. Cf. BARRos, Marco Antonio de, A busca da verdade no processo penal..., p. 22.

319 Antonio Magalhães Gomes Filho, Direito à prova no processo penal..., p. 91; GRINOVER, Ada Pellegrini, FERNANDES, Antonio Scarance, GOMES FILHo, Antonio Magalhães, As nulidades no processo penal..., p. 154.
} 
mediante a transposição dos limites impostos pela lei. ${ }^{320}$ Desta forma, a restrição do direito à prova de uma parte corresponde ao direito à prova corretamente obtida da outra. ${ }^{321}$ Do contrário seria melhor apagar o inciso LVI do artigo $5^{\circ}$ da Constituição Federal, o qual torna inadmissível qualquer prova produzida ilicitamente.

Nesse sentido, há que se destacar que o julgador não dispõe de plena liberdade para averiguar os fatos como um historiador, havendo algumas barreiras que delimitam seu campo de atuação. Existe tanto uma limitação fática, pois o juiz está adstrito à pesquisa acerca daquilo que lhe é relatado nos autos, quanto instrumental, uma vez que não dispõe de todo e qualquer meio para levar a cabo sua tarefa de investigação. ${ }^{322}$

Pitombo utiliza-se de uma figura muito interessante para ilustrar a imperfeição da verdade que podemos atingir. Com base em Nicolau de Cusa, afirma que a inteligência humana é limitada, não sendo hábil a compreender toda a verdade. Assim, aduz que o entendimento está para a verdade assim como o polígono está para o círculo. Por mais faces que possua um polígono, ele nunca chegará a ser um círculo. Da mesma forma, por mais esforços que se despenda, o entendimento nunca compreenderá a realidade dos fatos, apenas se aproximará dela. ${ }^{323}$

Cleunice Pitombo analisa todas as correntes filosóficas sobre a verdade em sua obra "Processo Penal: Prova e Verdade", e reconhece a impossibilidade de atingir a verdade ontológica. A autora descreve a teoria da verdade aproximativa, desenvolvida por Bachelard, segundo a qual a verdade não é mera concordância entre o pensamento e a realidade, mas sim uma infinita aproximação entre as teorias propostas e a realidade. Essa concepção reflete os ensinamentos de dois filósofos, Popper e Tarski, que consideram a verdade absoluta inatingível. ${ }^{324}$

\footnotetext{
${ }^{320}$ BARros, Marco Antonio de, A busca da verdade no processo penal..., p. 218.

${ }^{321}$ GOMES FILHO, Antonio Magalhães, Direito à prova no processo penal..., p. 93.

${ }^{322}$ ZILLI, Marcos Alexandre Coelho, A iniciativa instrutória do juiz...., p. 113.

${ }^{323}$ PITOMBo, Sergio Marcos de Moraes, O juiz penal e a pesquisa da verdade material, in PoRTo, Hermínio Alberto Marques e SILVA, Marco Antonio Marques da (orgs), Processo Penal e Constituição Federal, São Paulo, Acadêmica, 1993, p. 74.

${ }^{324}$ PIтомво, Cleunice, Processo Penal..., p. 93-95.
} 
Ferrajoli concebe a verdade processual como uma verdade aproximativa nos termos sugeridos por Popper. ${ }^{325}$ Nesse sentido, a verdade objetiva seria um modelo ao qual não poderíamos nos igualar, mas ao qual seria possível se acercar. ${ }^{326}$ Esse modelo é aplicável tanto às ciências empíricas quanto ao Processo Penal, e conforme anota Cleunice Pitombo:

"Pode-se afirmar, aqui, que a investigação científica e a reconstrução do fato típico, no processual penal alcançam resultados aproximativos - porque a verdade consiste um limite ideal, mas inatingível e inalcançável, na plenitude. ${ }^{\prime 327}$

Posto isso, cumpre, ainda, destacar que para Luigi Ferrajoli uma proposição jurisdicional só pode ser considerada verdadeira se assim o for fática e juridicamente. Em outras palavras, o autor italiano decompõe a verdade processual em: fática, referente à prova da ocorrência do fato; e jurídica, relativa à interpretação das normas incidentes sobre o fato, que o qualificam como delito. Àquela se chega por indução a partir dos dados da realidade, ao passo que esta é atingida por dedução a partir da lei. ${ }^{328}$

Ferrajoli enumera algumas razões que levam a verdade processual a ser apenas aproximativa. A primeira delas consiste no fato de a verdade, tanto em seu aspecto fático quanto no jurídico, não poder ser afirmada por observações diretas, como ocorre em uma investigação científica. No que tange ao aspecto fático, temos que o juiz não foi testemunha ocular dos fatos e limita-se ao que está relatado nos autos, constituindo-se uma hipótese de probabilidade. Já quanto ao aspecto jurídico, existem dificuldades para efetuar a subsunção do fato à norma, pois, não obstante a imperfeição da descrição dos fatos, os

\footnotetext{
${ }^{325}$ DUCLERC, Elmir, Prova Penal e Garantismo: uma investigação crítica sobre a verdade fática construída através do processo, Rio de Janeiro, Editora Lumen Juris, 2004, p. 114.

${ }^{326}$ FerrajOLI, Luigi, Direito e Razão..., p. 52.

327 Pitombo, Cleunice Processo Penal..., p. 95.

${ }^{328}$ FERRAJOLI, Luigi, Direito e Razão..., p. 56-57.
} 
conceitos classificatórios contidos nas normas costumam admitir diversas interpretações, resultando numa verdade jurídica opinativa. ${ }^{329}$

Outra razão pela qual a verdade é meramente aproximativa reside na subjetividade do juiz. ${ }^{330}$ Isso porque o juiz é um ser humano dotado de sentimentos, moldado pelo ambiente em que vive e que possui valores próprios e esses fatores não são afastados totalmente quando toma suas decisões. Alia-se à subjetividade judicial a subjetividade das fontes de provas, tais como perícias, testemunhos e interrogatório. ${ }^{331}$ Ademais, a própria transcrição efetuada pelos auxiliares da Justiça acaba por descaracterizar esses depoimentos. $^{332}$

Por derradeiro, existe um fator que impede o alcance da verdade ontológica que se aplica apenas ao âmbito jurídico. Sua natureza é normativa, uma vez que o método de investigação deve observar algumas regras com os mais diversos fins para ser considerada válida. Algumas visam a evitar práticas arbitrárias, outras a impedir a prevaricação das partes ou ainda a determinar a conduta a ser adotada em casos de dúvida, como o brocado "in dubio pro reo". A importância dessas regras advém tanto da necessidade de se barrar previamente condutas ilegais, quanto da necessidade de o juiz decidir mesmo no caso de incerteza. $^{333}$

\footnotetext{
${ }^{329}$ FerRAJOLI, Luigi, Direito e Razão..., p. 54-56; CRUZ, Rogério Schietti Machado, A verdade processual em Ferrajoli, in Boletim IBCCRIM, São Paulo, v. 9, n. ${ }^{\circ}$ 106, set. 2001, p. 9.

330 Observe-se, nos termos do exposto no item 3.2.1, que as regras relativas à isenção visam a minimizar os efeitos da subjetividade, mas é impraticável exterminá-la de maneira absoluta.

${ }^{331}$ Cumpre, aqui, observar que muitas vezes duas testemunhas oculares do mesmo fato relatam-nos de forma diversa. Disso não decorre necessariamente que uma delas esteja mentindo conscientemente. Cada uma teve uma percepção diferente do fato. Aqui reside a diferença entre verdade e certeza. Enquanto aquela expressa a conformidade do pensamento com a realidade, esta consiste na crença na percepção da conformidade. Desta forma, podemos afirmar que a certeza relaciona-se com o estado subjetivo do espírito e, muitas vezes, pode destoar da verdade objetiva. Ver BARROS, Marco Antonio de, A busca da verdade no processo penal..., p. 23; SILVEIRA, Renato de Mello Jorge Da verdade dada à verdade buscada, in Boletim IBCCRIM, São Paulo, n. ${ }^{\circ}$ 101, abril 2001, p. 13.

${ }^{332}$ FERRAJOLI, Luigi, Direito e Razão..., p. 61.

${ }^{333}$ Duclerc, Elmir, Prova Penal e Garantismo..., p. 132; Ferrajoli, Luigi, Direito e Razão..., 63-64. A questão da incerteza no processo é mais delicada do que em outras ciências, porque nestas a investigação pode dar-se ad eternum sem que se tenha que chegar a uma conclusão definitiva. Já o juiz tem o dever de decidir, pois o processo precisa terminar. Não apenas pela falta de recursos e tempo, mas pela necessidade de conferir alguma segurança jurídica às partes. Renuncia-se à obtenção da verdade absoluta em troca de uma pacificação do conflito mais célere, contentando-se com a probabilidade. Além disso, há de se observar as limitações impostas pelos direitos individuais. Cf. op. cit. p. 45; HASSEMER, Winfried Fundamentos del Derecho Penal..., p. 186-187; BelloQUe, Juliana Garcia, Sigilo bancário: análise crítica da LC 105/2001,
} 
Percebe-se, assim, que o princípio da verdade material, na realidade, não existe. É apenas uma regra costumeira do Processo Penal, segundo a qual deve haver uma tendência à reconstrução dos fatos como efetivamente ocorreram, mas se deve sempre ter em mente que a verdade só pode ser apurada por meios lícitos, o que limita essa reconstrução. ${ }^{334}$

Nessa conjuntura, Hassemer assevera que a meta do Processo Penal é a obtenção formalizada da verdade, a verdade forense, pois o próprio direito impede a averiguação que seria desejável para fundamentar uma decisão. Do contrário, a investigação poderia engendrar danos aos indivíduos, tanto em seu aspecto corporal quanto no espiritual e no social. Assim, os direitos individuais embaraçam a completa averiguação da verdade. ${ }^{335}$

Neste ponto, é oportuna a transcrição de um trecho da obra de Marco Antonio de Barros:

\begin{abstract}
"O só fato de se ter de dosar corretamente os limites da busca da verdade material significa que ela não transita por um campo infinitamente aberto e sem barreiras legais. Com efeito, a investigação da verdade não pode invadir a órbita da imoralidade a pretexto de transformar-se, ela própria, no objetivo supremo do processo penal. Isto é inaceitável porque, em primeiro lugar, o objetivo maior do processo é produzir a verdadeira justiça, ou seja, todos os atos que o compõem se dirigem à concretização desta. E, em segundo lugar, na realização da justiça não se compreende a subversão de preceitos morais
\end{abstract}

São Paulo, Editora Revista dos Tribunais, 2003, 168; DinAMARCO, Cândido Rangel, A instrumentalidade do processo..., p. 290-291.

${ }^{334}$ PIтомBO, Sergio Marcos de Moraes $O$ juiz penal e a pesquisa da verdade material..., p. 74-75. Nesse diapasão, Tourinho Filho ressalta que os meios de coletar dados conferidos ao juiz penal devem ser utilizados somente para restaurar o crime na medida do possível. Cf. Manual de processo penal..., p. 17. Ainda, Marcos Alexandre Coelho Zilli afirma que considerando ser impossível atingir a verdade plena, parece plausível pensar na meta da busca da verdade como certeza subjetiva. A certeza configura um estado de espírito relativo à segurança subjetiva acerca da verdade. Diferencia-se do juízo de probabilidade, no qual se estima aproximar-se de um resultado, e a dúvida, na qual não se logra atingir o objetivo. Ver ZILLI, Marcos Alexandre Coelho, A iniciativa instrutória do juiz..., p. 112.

${ }^{335}$ Hassemer, Winfried, Fundamentos del Derecho Penal..., p. 190. 
condizentes com os direitos e garantias individuais nomeados pelo Direito Constitucional". ${ }^{336}$

Depreende-se do exposto que foi construída uma nova concepção da verdade perquirida no processo, a chamada verdade processualmente possível, que visa a chegar o mais perto possível da verdade absoluta sem olvidar o justo e devido processo. ${ }^{337}$ Segundo Elmir Duclerc, teremos sempre uma verdade normativa, comprometida com condições de convalidação que exigem a observância de regras processuais instituidoras de meios de prova admissíveis e de um método de investigação da verdade. Dessa ótica, só são aceitáveis as provas produzidas de acordo com as regras do jogo. ${ }^{338}$

Nesse sentido, os direitos e garantias individuais emergem como legítimas barreiras à reconstrução dos fatos na instrução criminal. ${ }^{339}$ São os chamados limites probatórios de natureza política, de acordo com a terminologia utilizada por Magalhães. ${ }^{340}$

Dessa maneira, a solução que se mostra adequada é o sacrifício da obtenção da verdade para preservar a inviolabilidade dos direitos fundamentais. Embora se reconheça a imperfeição do resultado atingido, opta-se por privilegiar razões de ordem ética, de modo a legitimar a atividade instrutória, porquanto a reconstrução dos fatos não pode ser feita a qualquer preço. ${ }^{341}$ De acordo com Winfried Hassemer:

\footnotetext{
${ }^{336}$ BARRos, Marco Antonio de, A busca da verdade no processo penal..., p. 37.

337 Piтombo, Cleunice, Processo Penal: prova e verdade..., p. 116; ZILLI, Marcos Alexandre Coelho, A iniciativa instrutória do juiz..., no p. 114.

${ }^{338}$ DuClERC, Elmir, Prova Penal e Garantismo..., p. 146-147.

${ }^{339}$ HASSEMER, Winfried, Fundamentos del Derecho Penal..., p. 190; BelloQue, Juliana, Sigilo bancário..., p. 168; PITOMBo, Cleunice, Processo Penal: prova e verdade..., p. 140.

${ }_{340}$ GoMes FILHO, Antonio Magalhães, Direito à prova no processo penal..., p. 93.

341 GoMes FILHO, Antonio Magalhães, Direito à prova no processo penal..., p. 99; HASSEMER, Winfried Fundamentos del Derecho Penal..., p. 190; PIтомBo, Cleunice, Processo Penal: prova e verdade..., p. 140; BARros, Marco Antonio de, A busca da verdade no processo penal..., p. 37.
} 
“El precio son los derechos de la persona que sierve de médio de prueba y tales derechos 'cuestam' la completa averiguación de la verdad. „342

Com efeito, esclarece Magalhães que eventuais intromissões na esfera individual feitas sob a alegação de se atender ao interesse do processo acarretariam um custo desproporcional para uma sociedade fundada na defesa do indivíduo. ${ }^{343}$ Cleunice Pitombo chama atenção para a origem dessas limitações à prova, que decorrem da observância do devido processo legal e seus corolários. ${ }^{344}$

Um deles consiste na necessidade de as intervenções em direitos individuais serem perpetradas de forma legítima, haja vista a relativização do princípio da liberdade da prova $^{345}$, que deve conviver com os demais interesses protegidos pelo ordenamento. ${ }^{346} \mathrm{O}$ outro, decorrente deste, exige a decisão judicial para efetuar tal restrição, que está em consonância com toda a teoria da reserva de jurisdição aqui desenvolvida, uma vez que estaremos diante de conflitos de interesses constitucionalmente protegidos cuja solução definitiva depende da restrição de um deles. ${ }^{347}$

De todo o exposto, extrai-se que a violação de valores constitucionais para se chegar o mais perto possível da verdade não é aceitável. ${ }^{348}$ A implicação de tal conduta seria a ilicitude da prova obtida e sua conseqüente inadmissibilidade. ${ }^{349}$ É patente a

\footnotetext{
${ }^{342}$ HASSEMER, Winfried, Fundamentos del Derecho Penal..., p. 190.

${ }^{343}$ GOMES FILHO, Antonio Magalhães, Direito à prova no processo penal..., p. 99.

${ }^{344}$ Pitombo, Cleunice, Processo Penal: prova e verdade..., p. 142.

${ }^{345}$ Quando falamos em limitação da liberdade da prova, não pretendemos defender o sistema da prova legal e suas regras de avaliação. Nesse sentido, impera a liberdade de convencimento. A questão refere-se a regras de admissão e exclusão de algumas provas. Cf. GRINOvER, Ada Pellegrini, FERnANDES, Antonio Scarance, GOMES FILHO, Antonio Magalhães, As nulidades no processo penal..., p. 155; GoMES FILHO, Antonio Magalhães, Direito à prova no processo penal..., p. 92.

346 Barros, Marco Antonio de, A busca da verdade no processo penal..., p. 217; GOMES FILHO, Antonio Magalhães, Direito à prova no processo penal..., p. 98.

${ }^{347}$ Piтомво, Cleunice, Processo Penal: prova e verdade..., p. 146.

${ }^{348}$ PITOMBo, Cleunice, Processo Penal: prova e verdade..., p. 141; BARros, Marco Antonio, A busca da verdade no processo penal..., p. 218; GOMES FILHO, Antonio Magalhães, Direito à prova no processo penal..., p. 99.

349 BARros, Marco Antonio, A busca da verdade no processo penal..., p. 218; GoMES FILHO, Antonio Magalhães, Direito à prova no processo penal..., p. 107-108. Neste ponto, cumpre mencionar o esclarecimento feito por Magalhães acerca da inadmissibilidade das provas. Explica o autor que admissibilidade é um conceito processual que implica numa valoração prévia que visa a evitar a entrada de provas inidôneas no processo. Essa valoração pode ter finalidade processual, a fim de excluir provas que
} 
proibição da admissão de provas obtidas por meios ilícitos no processo, tendo em vista o disposto no inciso LVI do artigo $5^{\circ}$ da Carta Magna.

Contudo, nem sempre a prova que viola um direito fundamental será considerada ilícita. Excepcionalmente, ela pode ser aceita com o escopo de equilibrar valores fundamentais contrastantes. ${ }^{350}$ Quando ocorre um conflito de interesses, deve ser feita uma ponderação para se decidir qual prevalecerá. Essa decisão, em regra, privilegiará o direito individual envolvido, mas também poderá preponderar o interesse da produção da prova se forem respeitados alguns requisitos. É conclusão que emerge da aplicação do postulado da proporcionalidade.

Esse postulado baseia-se em um estado de necessidade de investigação e, conforme já observado, só permite a violação se forem atendidos três requisitos: a adequação da medida para atingir o resultado almejado; a necessidade de ser aplicada, isto é, ser o menos onerosa possível; e proporcionalidade em sentido estrito, devendo haver uma equivalência entre os danos que serão causados e o benefício que será extraído. Outrossim, apenas o Poder Judiciário possui legitimação para sopesar os interesses e autorizar a restrição a um direito fundamental. ${ }^{351}$

Nesse sentido, Cleunice Pitombo destaca a necessidade de intervenção do Poder Judiciário, ponto fulcral deste estudo, e que nos remete novamente è idéia de que a reserva de jurisdição será aplicada nos casos em que houver conflitos de interesses que possam resultar em restrições a direitos fundamentais. ${ }^{352}$

Feitas todas essas digressões para nos contextualizar na realidade do Processo Penal, cumpre passar à análise casuística das hipóteses em que a reserva de jurisdição absoluta existe neste ramo do direito. Foram eleitas algumas medidas restritivas de direitos fundamentais para aprofundar o estudo, acerca das quais apontaremos o tipo de reserva absoluta a que se submetem e a razão dessa imposição.

reconstituiriam os fatos de forma inexata, ou finalidade material, quando quer excluir provas que violem outros direitos protegidos pelo ordenamento.

${ }^{350}$ BARros, Marco Antonio, A busca da verdade no processo penal..., p. 273.

${ }^{351}$ BARros, Marco Antonio de A busca da verdade no processo penal..., p. 272.

${ }^{352}$ PIтомво, Cleunice Processo Penal: prova e verdade..., p. 146. 


\subsection{MEDIDAS RESTRITIVAS DE DIREITOS FUNDAMENTAIS UTILIZADAS NA INSTRUÇÃO PROCESSUAL E SUBMETIDAS À RESERVA DE JURISDIÇÃO ${ }^{353}$}

Preocupados em situar o tema da reserva de jurisdição no âmbito do Processo Penal, fizemos uma breve digressão sobre as finalidades deste ramo do direito, o que influencia a forma de atuação do juiz, bem como o direcionamento da instrução processual, o que ficou claro na explanação acerca da busca da verdade.

A instrução processual serve para embasar a decisão a ser tomada, auxiliando a formação da convicção do juiz por meio da descoberta dos fatos. ${ }^{354}$ Considerando que toda pretensão relaciona-se a algum fato e que as questões a eles atinentes devem ser solucionadas para se escolher a norma a ser aplicada, a prova emerge como instrumento central de averiguação da verdade, trazendo os fatos externos para dentro do processo. ${ }^{355}$

De acordo com Inaki Riano Brun:

"Los actos de comprobación y averiguación judicial son aquellos que se realizan em la fase de instrucción com el objetivo de conocer las circunstancias que se han dado em la comisión del delito, así como la identidad del delincuente, preparando de esta manera el juicio oral y proporcionando los elementos fácticos y personales necesarios para formular la acusación y plantear la defensa. „356

\footnotetext{
${ }^{353}$ Cumpre observar que não é apenas no campo probatório que podem ser efetivadas medidas restritivas de direito no processo penal. As prisões são exemplos de medidas que tolhem um direito individual do cidadão, a liberdade, e também podem ocorrer no bojo do processo, sendo indispensável a prolação de uma ordem judicial para sua concretização nos termos no inciso LXI do artigo $5^{\circ}$ da Constituição Federal. No entanto, em face do tema deste estudo, que se refere às investigações levadas a cabo pelas Comissões Parlamentares de Inquérito, optamos por restringir a análise aprofundada ao âmbito dos instrumentos utilizados na instrução processual, notadamente aqueles de maior utilização no bojo do inquérito parlamentar.

${ }^{354}$ Para maiores detalhes, ver item 6.1.2.

355 Grinover, Ada Pellegrini, Fernandes, Antonio Scarance, Gomes Filho, Antonio Magalhães, As nulidades no processo penal, $10^{\mathrm{a}} \mathrm{ed}$. rev e atual, São Paulo, Editora Revista dos Tribunais, 2007, p. 143.

${ }^{356}$ BRUn, Inaki Riano La instrucción Criminal em el Proceso Penal, Navarra, Thomson Aranzadi, 2008, p. 95.
} 
Teresa Armenta Deu expõe que existem duas correntes sobre a natureza jurídica da instrução no direito espanhol. A primeira concebe-a como atividade administrativa e a segunda lhe confere caráter processual. Sem dúvida, a autora é adepta desta última, mais garantista, segundo a qual a instrução processual envolve atividades inegavelmente jurisdicionais, como a adoção de medidas cautelares pessoais e reais, a prática de atos de investigação limitadores de direitos fundamentais e a garantia das provas. Perceba-se que este posicionamento está em consonância com nossa tese acerca da aplicação da reserva de jurisdição para a efetivação dos atos investigatórios e instrutórios, sobretudo os que ensejam restrições a direitos fundamentais. ${ }^{357}$

Conforme bem apontado pelo Professor Antonio Magalhães Gomes Filho, o termo prova possui natureza polissêmica, quer dizer, é dotado de diversas acepções. A origem do vocábulo relaciona-se com as operações intelectuais que buscam o conhecimento verdadeiro. $^{358}$

Outrossim, há que se ressaltar o caráter jurisdicional da prova, pois, em conformidade com o modelo acusatório, a busca da verdade só pode ser efetuada por meio do método dialético, ou seja, com contribuição da acusação e defesa, em contraditório, perante o juiz natural. Assim, a definição de prova carrega a idéia de jurisdicionalidade. ${ }^{359}$

É sabido, entretanto, que a matéria não se restringe ao mero conceito de prova. Dentro deste tema foram feitas classificações do instituto, bem como foram identificados componentes a ele essenciais. Para os fins de nosso trabalho, é interessante analisar o conceito de fontes de prova, meios de prova e meios de investigação.

Na clássica definição de Tourinho Filho, "Entende-se por fonte de prova tudo quanto possa ministrar indicações úteis, cujas comprovações sejam necessárias" e meio

\footnotetext{
${ }^{357}$ Deu, Teresa Armenta, Leciones de Derecho Procesal Penal, $3^{\text {a }}$ Ed., Madrid, Marcial Pons, 2007, p. 121. Sem prejuízo desse entendimento, que trata especialmente da instrução desenvolvida no bojo do processo, é possível conceber a prática de atos instrutórios na fase administrativa, conforme explicaremos no item 6.1.2. 358 GOMES FILHO, Antonio Magalhães. Notas sobre a terminologia da prova (reflexos no processo penal brasileiro), in Yarshel, Flávio Luiz e Moraes, Mauricio Zanoide (org), Estudos em homenagem à Professora Ada Pellegrini Grinover, São Paulo, DPJ Editora, 2005, p. 303-305.

${ }^{359}$ Mercone, Mario, Diritto Processuale Penale, XVI Edizione, Esselibri-Simone, Napoli, 2008, p. 241.
} 
de prova "é tudo quanto possa servir, direta ou indiretamente, à comprovação da verdade que se procura no processo", ${ }^{360}$ O Professor Magalhães atualiza os conceitos afirmando que "fala-se em fonte de prova para designar as pessoas ou coisas das quais pode-se conseguir a prova" e que meios de prova são "os instrumentos ou atividades por intermédio dos quais os dados probatórios (elementos de prova) são introduzidos e fixados no processo (produção da prova)". 361

Ressalte-se, ainda, a diferença existente entre meios de prova com meios de investigação de prova. Estes últimos são os instrumentos por meio dos quais se garante ao processo a fonte de prova, definição que revela uma natureza mais interventiva. ${ }^{362}$

O Código de Processo Penal italiano distingue ambos os institutos, e Paolo Tonini compara-os afirmando que, nos meios de prova, o elemento probatório forma-se após sua realização, enquanto que, nos meios de investigação de prova, o elemento adquirido é préexistente. Ainda, ao passo que os primeiros são produzidos apenas em contraditório perante o juiz, os últimos podem ser levados a cabo até mesmo pela polícia judiciária, com a utilização do fator surpresa. ${ }^{363}$

As observações de Denilson Feitoza prestam auxílio ao esclarecimento da distinção:

"Os meios de prova são as coisas, pessoas e suas manifestações (declarações, documentos etc.) que podem levar estímulos sensoriais à percepção da entidade decisora e formar sua convicção sobre a existência ou não de um fato. Os meios de obtenção de prova são os meios que permitem a obtenção dessas coisas, pessoas e manifestações. Nesse sentido, por exemplo, a busca de um documento, em cumprimento de um mandado de busca e apreensão, é um meio de obtenção de

\footnotetext{
${ }^{360}$ TourinHo FILHO, Fernando da Costa, Manual de processo penal..., p. 491.

${ }^{361}$ GOMES FILHO, Antonio Magalhães Notas sobre a terminologia da prova..., p. 308.

362 GoMES FILHO, Antonio Magalhães Notas sobre a terminologia da prova..., p. 309; MERCONE, Mario, Diritto Processuale Penale..., p. 349.

${ }^{363}$ TONINI, Paolo A prova no processo penal italiano, Alexandra Martins e Daniela Mróz (trad.), São Paulo, Editora Revista dos Tribunais, 2002, p. 242-243.
} 
prova. O documento que está sendo procurado e que, se encontrado, poderá ser apreendido, é que é o meio de prova.",364

Eduardo Diniz Neto afirma que os meios de prova e os meios de obtenção de prova diferenciam-se sob duas perspectivas: a lógica e a técnico-operativa. Para o autor, os meios de prova são a própria fonte de convencimento sob a perspectiva lógica ao passo que se apresentam como elemento de prova ou resultado sob a perspectiva técnico-operativa. Já os meios de obtenção de prova são instrumento para a colação dos meios de prova numa perspectiva lógica e possuem a peculiaridade de serem adquiridos em fases preliminares do processo, inclusive no inquérito, sob uma ótica técnico-operativa. ${ }^{365}$

Perceba-se que a própria denominação de meios de obtenção revela um instrumento que alcança algum objeto e, para tanto, perpetra uma invasão a um bem jurídico. Em alguns casos, a realização dos meios de obtenção de prova enseja grandes invasões ou restrições a direitos fundamentais do investigado, de sorte que surgirá um conflito com o direito à segurança ou do interesse de punir do Estado.

Assim, constatada a presença dos elementos destacados como critérios para eleição das situações submetidas à reserva de jurisdição absoluta no item 3.3 supra, isto é, havendo um conflito entre interesses de alta relevância, notadamente, direitos fundamentais e bens constitucionalmente protegidos e, sendo necessária a restrição de um deles para se solucionar tal conflito, a manifestação judicial no caso será imprescindível.

Em alguns casos, essa exigência já foi prevista na lei, quiçá até mesmo no texto constitucional, de maneira que nos incumbe definir o instituto e esclarecer a forma de operacionalização da reserva de jurisdição quando de sua utilização. Outros casos, porém, não trazem previsão expressa, de sorte que será necessária a verificação do cabimento da tese aqui defendida.

\footnotetext{
${ }^{364}$ PACHECO, Denilson Feitoza, Direito processual penal..., p. 604-605.

${ }^{365}$ DINIZ NETO, Eduardo, Meios de obtenção de prova criminal: considerações de direito constitucional aplicado, in Revista da Associação Brasileira de Professores de Ciências Penais, ano 4, n. ${ }^{\circ}$ 6, jan-jun/2007, p. 160 .
} 
Por óbvio, os casos de reserva de jurisdição, seja ela constitucional, legal ou implícita, são muito mais numerosos do que os que serão aqui esmiuçados. Todavia, dada a proposta desde estudo, elegemos aqueles que revelam maior importância na prática das Comissões Parlamentares de Inquérito, de modo a não dilatar o capítulo de forma desmedida.

Trataremos da condução coercitiva de testemunha, que consiste em uma maneira de se obrigar a fonte de prova (testemunha) a realizar o meio de prova (depoimento); da busca e apreensão; da interceptação telefônica; da quebra do sigilo de dados; e da quebra do sigilo financeiro.

A maioria das medidas acima relacionadas tem a natureza única de meio de obtenção de prova, que, em geral, é mais invasivo do que um meio de prova. Todavia, é possível imaginar uma medida restritiva de direito fundamental que não se encontra entre essas apontadas e que consiste em um meio de prova.

Imaginemos um processo administrativo tributário cujo conteúdo está acobertado pelo sigilo fiscal do contribuinte, isto é, as informações nele existentes são atinentes à esfera da intimidade do indivíduo, como aquelas relativas ao patrimônio que constitui fato gerador de um determinado imposto. Constatada a ocorrência de fraude tributária, a cópia deste processo, que possui natureza de prova documental, poderá ser acostado aos autos da ação penal respectiva. Desta forma, um meio de prova, o documento, perpetrará uma violação a um direito fundamental do indivíduo, assim, a autorização judicial para que a Receita Federal forneça esses dados é medida que se impõe. ${ }^{366}$

Feita esta breve observação, cumpre pontuar os casos mais relevantes de medidas restritivas de direito no âmbito das Comissões Parlamentares de Inquérito.

\footnotetext{
${ }^{366}$ Observe-se que a diferença existente entre a juntada de um procedimento com dados acobertados pelo sigilo fiscal e uma quebra de sigilo bancário, por exemplo, além do conteúdo das informações, está no fato da quebra do sigilo bancário ser um meio de investigação por meio do qual podem ser encontrados ou não elementos de prova. A cópia de um documento é diferente. Já possui os elementos em seu bojo, sendo necessária apenas a transferência destes para o processo.
} 


\subsubsection{CONDUÇÃO COERCITIVA DE TESTEMUNHA}

Nos termos do artigo 218 do Código de Processo Penal, a testemunha pode ser conduzida coercitivamente, pelo Oficial de Justiça ou força policial, no caso de, conquanto regularmente intimada, não comparecer perante o juiz sem justificativa. ${ }^{367}$ Diante do mandamento legal, Renato Marcão e Rodrigo A. F. Tanamati assentam que:

“... a testemunha regularmente intimada tem o dever legal de comparecer à sessão realizada pela Comissão Parlamentar de Inquérito e responder aos questionamentos que lhe forem dirigidos, ressalvadas as exceções legais. Caso não compareça espontaneamente, poderá ser determinada sua apresentação mediante condução coercitiva. "368

A antiga Lei n. $^{\circ}$ 1.579/52, que regula os poderes das Comissões Parlamentares de Inquérito, é expressa ao afirmar que no caso de não comparecimento de uma testemunha, há que se solicitar ao juiz criminal da localidade sua intimação, nos termos do artigo 218 do Código de Processo Penal. Ocorre que, como se verá adiante, no item 5.4, existem dois posicionamentos sobre a recepção deste texto legal. ${ }^{369}$

Segundo Luiz Carlos dos Santos Gonçalves, essa lei foi recepcionada pela Constituição de 1988 apenas no que tange aos tipos penais criados, uma vez que o constituinte tratou de todos os demais aspectos e conferiu às CPIs poderes equiparados aos das autoridades judiciais. ${ }^{370}$

\footnotetext{
${ }^{367}$ PACHECO, Denilson Feitoza, Direito processual penal..., p. 654.

368 MARCÃo, Renato e TANAMATI, Rodrigo A. F., Condução coercitiva determinada por Comissão Parlamentar de Inquérito, in ICP, ago/2006, p. 7.

${ }^{369}$ Idem, p. 8.

370 GonçAlves, Luiz Carlos dos Santos, Poderes de Investigação das Comissões Parlamentares de Inquérito..., p. 47-49; 143.
} 
Para outros autores, todavia, como Rogério Lauria Tucci e Cassio Juvenal Faria, a Lei n. ${ }^{\circ}$ 1.579/52 permanece em vigor neste ponto, de modo que apenas o Poder Judiciário pode determinar a condução coercitiva de uma testemunha, porquanto implica restrição do direito de ir e vir do depoente. ${ }^{371}$ Esta visão coaduna-se com a tese aqui defendida sobre os atos materialmente jurisdicionais e a exclusividade de seu exercício pelos magistrados.

Para o primeiro autor, a menção que a Carta de 1988 faz aos poderes próprios de autoridade judiciária não é compatível com a exigência de solicitação ao juiz. ${ }^{372}$ Da mesma opinião compartilham Yuri Carajelescov, Renato Marcão, Rodrigo Tanamati e Paulo Hamilton Siqueira Jr. ${ }^{373}$ Contudo, não é nosso entendimento, como passamos a explicar.

A condução coercitiva de testemunha nada mais é do que uma maneira de se obrigar a fonte de prova (testemunha) a realizar o meio de prova (depoimento). Com efeito, Antonio Scarance Fernandes ensina que: "Testemunha é pessoa que presta declarações a respeito de um fato de que tem conhecimento, ou, ainda, sobre aspectos ligados a determinada pessoa. "374

Nesse caso, o meio de prova em si não enseja uma restrição a qualquer direito fundamental. Porém, se a fonte de prova se recusar a comparecer espontaneamente, sua produção dependerá de um ato coercitivo e, a partir daí, este mecanismo causará uma restrição de liberdade. Ora, ao se compelir uma pessoa a comparecer a um determinado local para prestar um depoimento, mediante o uso da força, estar-se-á limitando sua liberdade de ir e vir, em prol do interesse da persecução penal.

Percebe-se, claramente, a existência de um conflito de interesses constitucionalmente protegidos, em que um deles acaba sendo limitado para a garantia da efetivação do outro. Nessa situação, aplicando-se a tese por nós defendida neste estudo, não há outra solução que não a exigência de uma intervenção judicial.

371 TuCCI, Rogério Lauria, Comissão Parlamentar de Inquérito (Atuação - Competência - Caráter Investigatório), in Revista Brasileira de Ciências Criminais, ano 2, n. ${ }^{\circ}$ 6, abril-junho - 1994, p. 174-175.

372 Gonçalves, Luiz Carlos dos Santos, Poderes de Investigação das Comissões Parlamentares de Inquérito..., p. 145.

${ }^{373}$ CARAJelescov, Yuri, Comissões Parlamentares de Inquérito à luz das disciplinas constitucional, legal e jurisprudencial luso-portuguesa e brasileira, Curitiba, Juruá Editora, 2007, p. 137; MARCÃO, Renato e Tanamati, Rodrigo A. F., Condução coercitiva..., p. 8; SiQueIRA JR., Paulo Hamilton, Comissão Parlamentar de Inquérito, Rio de Janeiro, Elsevier, 2007, p. 123.

${ }^{374}$ FERNANDES, Antonio Scarance Processo Penal Constitucional..., p. 82. 
Assim, a reserva de jurisdição emerge como inafastável no caso, restando apenas a definição de sua espécie. Entendendo que a Lei n. ${ }^{\circ}$ 1.579/52 continua vigente, nos termos do que foi exposto, estaremos diante de um caso de reserva de jurisdição legal, porquanto a condução coercitiva de testemunha é expressamente condicionada à autorização judicial pelo texto de uma lei ordinária.

Ressalte-se, entretanto, que mesmo se adotada a posição segundo a qual referido texto legal não foi recepcionado pela nova ordem constitucional, a reserva de jurisdição deveria ser extraída de forma implícita do ordenamento, em virtude do confronto entre bens constitucionalmente protegidos. Isso porque constatamos a existência dos três critérios encontrados no item 3.3: existe um conflito de interesses; estes têm magnitude constitucional; e a solução da controvérsia pode levar a uma intervenção em um direito fundamental.

\subsubsection{BUSCA E APREENSÃO}

Considerando a freqüente utilização conjugada das palavras, muitos se referem à busca e apreensão como um instituto único. Todavia, trata-se de duas atividades distintas. A busca tem por finalidade procurar pessoas ou coisas. Já a apreensão visa a obter esses objetos ou indivíduos e evitar seu desaparecimento. Fato é que, em geral, são executados de maneira conjunta e, juntos, constituem um importante meio de obtenção de provas documentais, na maior parte das vezes. No entanto, também podem ser utilizados para capturar objetos que serão empregados de outras formas, como na realização de uma perícia. ${ }^{375}$

Analisando os institutos de forma apartada, temos, nos exatos termos de Cleunice Pitombo, que estudou os institutos profundamente:

\footnotetext{
${ }^{375}$ PACHECO, Denilson Feitoza, Direito processual penal..., p. 665; PITOMBO, Cleunice Bastos, Da Busca e da Apreensão no Processo Penal, $2^{\mathrm{a}}$ ed. rev. atual. e ampl., São Paulo, Editora Revista dos Tribunais, 2005, p. 102-104. A confusão decorre do fato de que, na maioria das vezes, a apreensão segue a busca.
} 
“A busca, portanto, é ato de procedimento persecutivo penal, restritivo de direito individual (inviolabilidade da intimidade, vida privada, domicílio e da integridade física ou moral), consistente em procura, que pode ostentar-se na revista ou no varejamento, conforme a hipótese: de pessoa (vítima de crime, suspeito, indiciado, acusado, condenado, testemunha e perito), semoventes, coisas (objetos, papéis e documentos), bem como de vestígios (rastros, sinais e pistas) da infração. "376

Diante desse conceito, a autora conclui que a busca consiste em medida instrumental que produz restrição a alguns direitos fundamentais nesse processo de procura. Não se trata de meio de prova ou de obtenção de prova como se poderia crer, mas apenas uma medida que pode ter como uma de suas consequiências a apreensão de algo. ${ }^{377}$

Encontramos na doutrina a freqüente afirmação de que duas são as modalidades de busca: a domiciliar e a pessoal. Isso porque são as únicas regulamentadas pelo artigo 240 do Código de Processo Penal. Todavia, vem se afirmando que essa divisão é insuficiente, porquanto a busca pode ser efetuada em inúmeros locais, tais como veículos, locais públicos e locais sujeitos a segredo ou sigilo. ${ }^{378}$

A busca pessoal apresenta menores complicações, exigindo apenas a preservação da integridade física e moral da pessoa, nos termos do artigo $5^{\circ}$, incisos III e XLIX. Considerando eventual atentado à intimidade, podemos vislumbrar, também, envolvimento do inciso $\mathrm{X}$ do artigo $5^{\circ}$ da $\mathrm{CF}$. Como o Código de Processo Penal não trata especificamente do tema, basta dizer que a busca pessoal tem como intento procurar algo

\footnotetext{
${ }^{376}$ Pitombo, Cleunice Bastos, Da Busca e da Apreensão no Processo Penal..., p. 109.

${ }^{377}$ Idem, p. 116-117.

378 Idem, p. 125-126. Conquanto haja diversas categorias, daremos especial enfoque às tradicionais, considerando que este trabalho não tem como tema central o instituto da busca.
} 
no corpo, vestes ou pertences do indivíduo que possa servir de prova, tendo sempre como limite os direitos fundamentais mencionados neste parágrafo. ${ }^{379}$

O mesmo não se pode dizer sobre a busca domiciliar.

A proteção à casa é conferida pelo inciso XI do artigo $5^{\circ}$ da Constituição, que só permite o ingresso em seu interior com o consentimento do morador ou no caso de flagrante delito, desastre ou para se prestar socorro. Outra hipótese é no caso de haver determinação judicial, a qual só poderá ser cumprida durante o dia. ${ }^{380}$

Observe-se que se deve interpretar a expressão casa de maneira ampla, de modo a englobar todo e qualquer lugar ocupado pelo indivíduo, locais esses mencionados particularmente pelo artigo $150, \S 4^{\circ}$, do Código Penal, quais sejam, quaisquer compartimentos habitados; aposentos ocupados de habitação coletiva; e compartimentos não abertos ao público nos quais alguém exerce profissão ou atividade. Esta última hipótese abrange empresas e escritórios de advocacia, por exemplo, que são alvos comuns desse tipo de diligência. ${ }^{381}$

Cleunice Bastos Pitombo esclarece que no Processo Penal, ao contrário do direito material, a definição utilizada deve ser a mais ampla possível:

"Deve-se, assim, entender que a expressão casa, protegida constitucionalmente, designa qualquer lugar que, de um modo ou de outro, sirva de residência ou morada. Todo lugar que o indivíduo possa ter como refúgio e se agasalhar contra

\footnotetext{
${ }^{379}$ GrinOver, Ada Pellegrini, Fernandes, Antonio Scarance, Gomes Filho, Antonio Magalhães, As nulidades no processo penal..., p. 201; PIтOMBo, Cleunice Bastos, Da Busca e da Apreensão no Processo Penal..., p. 146.

${ }^{380}$ Grinover, Ada Pellegrini, Fernandes, Antonio Scarance, Gomes Filho, Antonio Magalhães, As nulidades no processo penal..., p. 201; PIтомBo, Cleunice Bastos, Da Busca e da Apreensão no Processo Penal..., p. 127.

${ }^{381}$ Grinover, Ada Pellegrini, Fernandes, Antonio Scarance, Gomes Filho, Antonio Magalhães, As nulidades no processo penal..., p. 201; PIтомво, Cleunice Bastos, Da Busca e da Apreensão no Processo Penal..., p. 68.
} 
a ingerência de terceiros, ainda que local de trabalho. O preceito legal admite, portanto, interpretação ampla. ,382

Por fim, vale mencionar a busca efetuada em lugar resguardado por segredo ou sigilo. Trata-se de locais onde a atividade profissional desenvolvida merece proteção diante da existência de grande quantidade de informações e objetos cuja revelação pode ensejar uma violação ao direito à intimidade, notadamente estabelecimentos bancários, consultórios médicos e escritórios de advocacia. A entrada em qualquer desses locais dependerá de ordem judicial que tenha avaliado a possibilidade de violação do direito fundamental envolvido no caso. ${ }^{383}$

O sigilo relativo aos escritórios de advocacia é de particular interesse para este estudo, uma vez que são muitos os casos em que as Comissões Parlamentares de Inquérito determinam invasões ilegais. Nossa lei processual não trata do assunto a fundo, mas de acordo com o $\S 2^{\circ}$ do artigo 243 , os documentos em poder do advogado do acusado não podem ser objeto de busca e apreensão, salvo se constituírem corpo de delito. Quer dizer que o direito de defesa é plenamente garantido por meio desse dispositivo. Além disso, é fora de questão que a busca nas bancas de advocacia deve respeitar o sigilo profissional, sendo imperiosa a estrita observância dos termos da ordem judicial. ${ }^{384}$

Tecidas essas breves considerações sobre a busca, passemos à apreensão. Sua natureza jurídica é multifária, nos termos de Cleunice Pitombo. Isso quer dizer que dependerá da função que exerce no caso, podendo se caracterizar como meio de prova,

\footnotetext{
${ }^{382}$ PItombo, Cleunice Bastos, Da Busca e da Apreensão no Processo Penal..., p. 68 e 71. No processo penal, quanto mais ampla a definição do termo, maior a proteção da esfera de intimidade do indivíduo. Ao contrário, no direito penal, se o conceito for demasiadamente amplo, acaba sendo criado um tipo penal demasiadamente aberto. Assim, a autora enumera os locais que devem ser abrangidos pela expressão casa em sua concepção processual: “...(a) habitação definitiva, ou morada transitória; (b) casa própria, alugada, ou cedida; (c) dependências da casa, sendo cercadas, gradeadas, ou muradas; (d) qualquer compartimento habitado; (e) aposento ocupado de habitação coletiva, em pensões, hotéis e em casas de pousada; $(f)$ estabelecimentos comerciais e industriais, fechados ao público; $(g)$ local onde se exerce atividade profissional, não aberto ao público; (h) barco, trailer, cabine de trem ou navio e barraca de acampamento; (i) áreas comuns de condomínio, vertical ou horizontal."

383 Pitombo, Cleunice Bastos, Da Busca e da Apreensão no Processo Penal..., p. 167-170.

384 Grinover, Ada Pellegrini, Fernandes, Antonio Scarance, Gomes Filho, Antonio Magalhães, As nulidades no processo penal..., 204; PITOMBo, Cleunice Bastos, Da Busca e da Apreensão no Processo Penal..., p. 172-173.
} 
meio de obtenção de prova, ou ainda, medida cautelar, podendo trazer prova material ao processo ou servir para guardar algo com urgência. Conceitua-se como:

“... ato processual penal, subjetivamente complexo, de apossamento, remoção e guarda de coisa semovente, e de pessoa, do poder de quem as retém ou detém, tornando-as indisponíveis, ou colocando-as sob custódia, enquanto importarem à instrução criminal, ou ao processo. Implica, sempre, constrição. "385

Depreendemos de ambos os conceitos que sempre haverá algum tipo de constrição, no caso da apreensão, ou restrição a direitos fundamentais, mais evidente na busca. Inclusive, esta é a única a possuir clara proteção constitucional, a qual exige que a diligência só será levada a cabo por meio de um mandado judicial, ressalvadas algumas poucas exceções já mencionadas. ${ }^{386}$ Todavia, é bem comum que a ordem de ambas seja expedida conjuntamente, o que as submete aos mesmos requisitos.

É inadmissível que se determine uma busca e posterior apreensão com restrição de direitos fundamentais sem que haja a devida intervenção jurisdicional, única apta a solucionar a colisão entre interesses constitucionalmente protegidos. ${ }^{387}$

Isso significa que, em se tratando de busca, estamos diante de um caso de reserva de jurisdição constitucional, porquanto a exigência da intervenção do Poder Judiciário advém do texto maior. Outrossim, por se caracterizar como exteriorização de uma

\footnotetext{
${ }^{385}$ Pitombo, Cleunice Bastos, Da Busca e da Apreensão no Processo Penal..., p. 295.

${ }^{386}$ Pitombo, Cleunice Bastos, Da Busca e da Apreensão no Processo Penal..., p. 102; Barroso, Luis Roberto, Comissões Parlamentares de Inquérito - Limite de sua competência - sentido da expressão constitucional "poderes de investigação próprios das autoridades judiciais" - inadmissibilidade de busca e apreensão sem mandado judicial, in Boletim de Direito Administrativo, ano XII, n. ${ }^{\circ}$ 12, dez. 1996, p. 799813.

${ }^{387}$ PItombo, Cleunice A. Valentim Bastos, Comissão Parlamentar de Inquérito e os institutos da busca e apreensão, in PENTEADO, Jaques de Camargo, Justiça Penal-7, São Paulo, Editora Revista dos Tribunais, 2000, p. 283-285.
} 
iniciativa instrutória, a medida só pode ser realizada no caso de haver uma decisão judicial criteriosa, com robustos fundamentos fáticos e jurídicos. ${ }^{388}$

Não obstante, também existe a previsão acerca da necessidade de decisão judicial para a perpetração da busca na Lei Ordinária, quer dizer, em nosso Código de Processo Penal (artigo 241), o que nos coloca, ao mesmo tempo, diante de uma hipótese de reserva de jurisdição legal. Assim, nenhuma outra autoridade pode expedir mandado de busca e apreensão, devendo limitar-se a provocar a sua expedição, se necessário. ${ }^{389}$

\subsubsection{INTERCEPTAÇÃO E GRAVAÇÕES TELEFÔNICAS}

A Constituição protege, além de outros bens jurídicos, a informação transmitida de um indivíduo a outro, qualquer que seja o meio pelo qual se operacionaliza a transmissão, mediante o inciso XII do artigo $5^{\circ}$. A Lei n. ${ }^{\circ}$ 9.296/96, em respeito aos ditames da reserva legal proporcional, veio regulamentar esse dispositivo estabelecendo os parâmetros para que se avalie se é caso de realizar interceptação da comunicação telefônica e, no caso de ser, traz o procedimento a ser adotado. ${ }^{390}$

A utilização deste meio de obtenção de prova é condicionada à existência de investigação criminal ou Processo Penal e a uma ordem judicial autorizando sua efetivação. Ressalte-se, por oportuno, que essas disposições também se aplicam à

\footnotetext{
${ }^{388}$ ZILLI, Marcos Alexandre Coelho, A iniciativa instrutória do juiz..., p. 201; PIтOMBO, Cleunice A. Valentim Bastos, Comissão Parlamentar de Inquérito..., p. 284. O Supremo Tribunal Federal acolhe a idéia de que a busca depende de expressa decisão judicial para ser efetivada, o que ficou bastante claro no MS 23.452, (STF Rel. Min. Celso de Mello, DJ de 12.05.2000), mas que também está consignado em outros julgados, como o MS 23.652/DF, Rel. Min. Celso de Mello, Pleno, DJ 16.02.2001. Observe-se, entretanto, que já houve decisão em sentido contrário, no HC 71.039, Rel. Min. Paulo Brossard, DJ de 14.04.94, entendendo-se que a CPI poderia decretar busca e apreensão.

${ }_{389}^{38}$ PIтомво, Cleunice A. Valentim Bastos, Comissão Parlamentar de Inquérito..., p. 294.

390 A Lei n. 9.296/96 trata apenas das comunicações telefônicas, como é possível extrair de seu artigo $1^{\circ}$. Ver MACHADO, André Augusto Mendes e KeHDI, Andre Pires de Andrade, Sigilo das comunicações e de dados, in FERnANDES, Antonio Scarance, AlmeidA, José Raul Gavião de, e Moraes, Maurício Zanoide de, Sigilo no processo penal: eficiência e garantismo, São Paulo, Editora Revista dos Tribunais, 2008, p. 250-251. Vale destacar que a questão atinente aos dados cadastrais telefônicos não diz respeito ao sigilo das comunicações telefônicas, mas sim ao sigilo de dados, também tratado pelo inciso XII do artigo $5^{\circ}$, que será abordado no item a seguir.
} 
interceptação do fluxo de informações no sistema de telemática e informática, conforme dispõe o parágrafo único do artigo $1^{\text {o }}$ da referida lei. ${ }^{391}$

Segundo Luiz Francisco Torquato Avolio:

“Juridicamente, as interceptações, lato sensu, podem ser entendidas como ato de interferência nas comunicações telefônicas, quer para impedi-las - com conseqüencias penais - quer para delas apenas tomar conhecimento - nesse caso, também com reflexos no processo. „392

Para os fins de investigação de fatos e instrução de um processo, a utilidade da interceptação é tomar conhecimento de circunstâncias das quais só poderia ter ciência por este meio. É requisito fundamental deste meio de obtenção de prova a realização da tarefa por meio de um terceiro, pois só um estranho à conversa pode intervir no momento da transmissão de informações de um indivíduo a outro. ${ }^{393}$

Note-se, ainda, que a interceptação telefônica é um meio de busca de prova peculiar, porquanto a captação da conversa exige, necessariamente, o desconhecimento de um deles

\footnotetext{
391 Já foi alegada a inconstitucionalidade dessa extensão, mas a doutrina assentou o entendimento de que, considerando que nenhum direito individual é absoluto, nada impede a regulamentação dos demais tipos de comunicações. MORAES, Alexandre de, A constitucionalidade do Parágrafo único do art. $1^{\circ}$ da Lei 9.296/96 (Interceptações do Fluxo de Comunicações em Sistemas de Informática e Telemática), in Boletim IBCCrim, n. ${ }^{\circ}$ 54, maio/1997, p. 5; BANDEIRA, Gustavo, A interceptação do fluxo de comunicações por sistemas de informática e sua constitucionalidade, in Revista de Direito do Tribunal de Justiça do Estado do Rio de Janeiro, n. ${ }^{\circ}$ 55, abril/junho de 2003, p. 40-42; FERnANDES, Antonio Scarance, Processo Penal Constitucional..., p. 100 e 103.

${ }^{392}$ AvOLIO, Luiz Francisco Torquato, Provas Ilícitas..., p. 92.

${ }^{393}$ Avolio, Luiz Francisco Torquato, Provas Ilícitas..., p. 150. Grinover, Ada Pelegrini, A Marcha do Processo, Rio de Janeiro, Forense Universitária, 2000, p. 103; FernandeS, Antonio Scarance, A Lei de Interceptação telefônica, in PENTEADO, Jaques de Camargo (coord.), Justiça Penal: críticas e sugestões: provas ilícitas e reforma pontual, São Paulo, Ed. Revista dos Tribunais, 1997, p. 48-70. A Lei de Interceptação telefônica..., p. 52.
} 
sobre a gravação. Caso contrário, não haverá utilidade na medida, pois não haverá a revelação dos dados desejados. ${ }^{394}$

No entanto, existem outros mecanismos de captação de conversas. Antonio Scarance Fernandes sintetizou as opções da seguinte forma:

“Enfim, são, resumidamente, espécies de captação de conversa: a) a interceptação da conversa telefônica por terceiro, sem o conhecimento dos dois interlocutores; $b$ ) a interceptação da conversa telefônica por terceiro, com o conhecimento de um dos interlocutores; c) a interceptação da conversa entre presentes por terceiro, sem o conhecimento de nenhum dos interlocutores; d) a interceptação da conversa entre presentes por terceiro, com o conhecimento de um ou alguns dos interlocutores; e) a gravação clandestina da conversa telefônica por um dos sujeitos, sem o conhecimento do outro; f) a gravação clandestina da conversa pessoal e direta, entre presentes, por um dos interlocutores, sem o conhecimento do(s) outro(s). „395

A Lei n. ${ }^{\circ}$ 9.296/96 tratou apenas das hipóteses que envolvem a utilização da interceptação telefônica feita por terceiro, sem o conhecimento dos interlocutores ou com o conhecimento de apenas um deles, caso em que se fala em escuta. Deixou de tratar dos casos de interceptação ambiental (captação de uma conversa entre presentes feita por terceiro com ou sem consentimento de um dos interlocutores) e gravação clandestina (telefônica ou entre presentes), que é feita por um dos interlocutores. ${ }^{396}$ Mas estes casos não ficam desprotegidos, aplicando-se a eles o amparo genérico do inciso $\mathrm{X}$ do artigo $5^{\circ}$. 397

\footnotetext{
${ }^{394}$ ZILLI, Marcos Alexandre Coelho, A iniciativa instrutória do juiz no processo penal, São Paulo, Editora Revista dos Tribunais, 2003, p. 204; Fernandes, Antonio Scarance, Processo Penal Constitucional..., p. 102-103.

${ }^{395}$ FERnANDES, Antonio Scarance, Processo Penal Constitucional..., p. 102-103.

${ }^{396} \mathrm{O}$ anteprojeto de lei que visa a alterar a lei em apreço, Projeto 3.272/2008, prevê que as gravações de conversa própria não se submetem à Lei (art. $3^{\circ}$ ), mas as interceptações ambientais sim (art. 20).

${ }^{397}$ Fernandes, Antonio Scarance, Processo Penal Constitucional..., p. 103; Grinover, Ada Pelegrini, A Marcha do Processo..., p. 103; FERnANDES, Antonio Scarance, A Lei de Interceptação telefônica..., p. 53;
} 
Referido diploma consagrou o mecanismo da interceptação telefônica como meio de obtenção de prova válido. Seus artigos $1^{\circ}$ e $2^{\circ}$ estabelecem como requisitos para a decretação da medida: existência de ordem judicial; motivação da decisão; presença de fundados indícios de autoria ou participação em infração penal (fumus boni iuris); subsidiariedade da medida, isto é, inexistência de outros meios para o alcance do resultado desejado (periculum in mora); investigação acerca de infração penal punida com reclusão; descrição detalhada do objeto da investigação; limitação temporal da interceptação; sigilo quanto a terceiros. $^{398}$

Todos os requisitos são importantes e indispensáveis, mas o nosso foco é a necessidade de autorização judicial, e é sobre ela que faremos nossas observações.

Merece destaque o fato de que a própria Constituição Federal, na redação dada ao inciso XII do artigo $5^{\circ}$ condiciona o afastamento do sigilo telefônico a uma decisão judicial. Isso significa que temos uma cláusula de reserva de jurisdição constitucional expressa, a qual não pode ser desrespeitada em nenhuma hipótese. Não obstante, a Lei n. ${ }^{\circ}$ 9.269/96 repete a exigência já no caput de seu artigo $1^{\circ}$, de maneira que a reserva torna-se também legal, porquanto prevista em lei ordinária.

Não se pode olvidar ser caracterizada como criminosa a conduta de realizar interceptação telefônica, informática ou telemática sem autorização judicial ou fora das hipóteses legais. Nesse caso, estaremos diante de prova ilícita, a qual não poderá ser admitida no processo como já explicitado acima. Também constitui crime a quebra do segredo de justiça, conforme determinado pelo artigo 10 da Lei n. ${ }^{\circ}$ 9296/96.

Feitas as observações necessárias sobre as interceptações e escutas, cumpre analisar a questão relativa à interceptação ambiental e às gravações. Com efeito, o Código de Processo Penal italiano estabelece que as gravações clandestinas também dependem de autorização judicial, como a interceptação telefônica. ${ }^{399}$ Em nosso sistema não é dessa

Machado, André Augusto Mendes e KeHDI, Andre Pires de Andrade, Sigilo das comunicações e de dados..., p. 252-253. Note-se que há entendimento no sentido de que a escuta telefônica não estaria englobada na regulamentação da lei em comento. Nesse sentido, AvOLIO, Luiz Francisco Torquato, Provas Ilícitas..., p. 163.

${ }^{398}$ ZILli, Marcos Alexandre Coelho, A iniciativa instrutória do juiz..., p. 204; MACHADO, André Augusto Mendes e KEHDI, Andre Pires de Andrade, Sigilo das comunicações e de dados..., p. 253.

${ }^{399}$ FERnANDES, Antonio Scarance, Processo Penal Constituciona..., p. 104. 
maneira, e Scarance afirma que a decisão judicial não é necessária para a perpetração da medida. Contudo, se a gravação clandestina tiver justa causa, poderá ser aceita no processo, ainda que não tenha havido a autorização judicial anterior. A falta de justa causa, todavia, leva à configuração do delito previsto no artigo 153 do Código Penal. ${ }^{400}$

De fato, soa estranho pensar que a gravação clandestina, executada por um dos interlocutores, precise de autorização judicial para ser realizada. Isso porque qualquer um pode gravar uma conversa da qual participe, não sendo necessária a intervenção de um terceiro, técnico, que utilize instrumentos para captar a conversa alheia. Todavia, a partir do momento em que existe a possibilidade de se violar o direito à intimidade do interlocutor que desconhecia a gravação, por meio da divulgação, a intervenção judicial se faz necessária para que se pondere os valores envolvidos. ${ }^{401}$

O raciocínio relativo às interceptações ambientais é um pouco diverso, uma vez que existe a atividade de um terceiro para a captação da conversa. No entanto, possuem algo em comum: nenhuma das medidas está acobertada pelo inciso XII do artigo $5^{\circ}$ da Constituição, mas encontram guarida no inciso $\mathrm{X}$ do mesmo dispositivo, cuja proteção à intimidade e vida privada é mais ampla.

Sendo assim, em se tratando de interceptações ambientais e gravações ambientais ou clandestinas, estaremos diante de casos de reserva de jurisdição absoluta implícita, porquanto derivam da proteção genérica à intimidade que, num determinado momento, colide com o interesse da instrução criminal e, conseqüentemente, com o direito à segurança. Para solucionar este conflito deverá haver a restrição de um dos interesses envolvidos, o que só poderá ser levado a cabo por um magistrado. Mais uma vez

\footnotetext{
${ }^{400}$ Fernandes, Antonio Scarance, Processo Penal Constitucional..., p. 105; Grinover, Ada Pelegrini, A Marcha do Processo..., p. 103; FERNANDES, Antonio Scarance, A Lei de Interceptação telefônica..., p. 53. Os Tribunais superiores brasileiros já admitiram a gravação efetuada por um dos interlocutores como prova lícita. Ver STF HC 75.338, RJ, Rel. Min. Nelson Jobim, DJ 11.03.98.

${ }^{401}$ A diferença deste método de gravação clandestina, efetuada pelo próprio interlocutor, de todas as demais medidas aqui estudadas, reside no fato de que, naquelas, sempre há a revelação de dados por um terceiro, ou ainda da execução de uma tarefa por uma pessoa que não é a titular do direito violado para, intervindo neste, obter informação relevante ao processo. Luis Francisco Torquato Avolio entende que a proibição relativa à divulgação do material gravado diz respeito ao direito à reserva, diferenciando-o do direito à intimidade que se refere à proibição de um terceiro se imiscuir na esfera de privacidade do outro. Ver Avolio, Luiz Francisco Torquato, Provas Ilícitas..., p. 100.
} 
constatamos a presença dos três requisitos mencionados no item 3.3 , o que revela a imperiosidade da decisão judicial.

Observe-se, entretanto, que, no caso das gravações, a reserva é postergada, uma vez que o ato material de gravar a conversa pode ser realizado sem intervenção judicial, mas a utilização de seu resultado como prova, não. Já as interceptações, realizadas por terceiro, podem ser autorizadas previamente. Tanto é assim que a Lei n. ${ }^{\circ}$ 10.217/2001 acrescentou à Lei n. ${ }^{\circ}$ 9.034/95 sobre o combate ao Crime Organizado norma que admite a interceptação ambiental, desde que haja autorização judicial (inciso IV do artigo $2^{\circ}$ ). ${ }^{402}$

Outrossim, não deve deixar de ser dito que a incorporação do resultado da gravação no processo nada mais será do que a produção de uma prova documental. ${ }^{403}$ Assim, estamos diante de um exemplo em que a reserva de jurisdição existe para a produção de um meio de prova, e não de um meio de obtenção de prova, que costumeiramente é mais invasivo. $^{404}$

\subsubsection{QUEBRA DE SIGILO DE OUTROS DADOS}

O inciso XII do artigo $5^{\circ}$ da Constituição Federal do Brasil, além de prever o sigilo das comunicações telefônicas, declara a inviolabilidade do sigilo de dados. No entanto, alguns autores, seguindo a posição de Tercio Sampaio Ferraz Junior ${ }^{405}$, defendem que o

\footnotetext{
${ }^{402}$ MACHAdO, André Augusto Mendes e KeHDI, Andre Pires de Andrade, Sigilo das comunicações e de dados..., p. 257.

${ }^{403}$ MARTOS, José Antonio de Faria, A natureza processual das provas produzidas através das interceptações telefônicas, in Revista Jurídica da Universidade de Franca, ano 8, n. ${ }^{\circ} 14,1^{\circ}$ sem., Franca, 2005, p. 141. Note-se que, para Antonio Scarance Fernandes, documento é "o registro de qualquer fato, qualquer manifestação do ser humano". Cf. Processo Penal Constitucional..., p. 84. Ainda segundo o autor, o documento é considerado direto quando o fato representado se transmite diretamente para a coisa representativa, como no caso da fonografia. Sendo a gravação a representação dos sons, não há dúvidas de que será um documento. Op. cit., p. 85.

${ }^{404}$ No caso da interceptação propriamente dita, a autorização judicial é exigida para a quebra do sigilo no ato da comunicação. O documento que dela advirá, bem como sua juntada nos autos, são resultados que independem do consentimento do magistrado.

${ }_{405}$ FERRAZ JUNIOR, Tercio Sampaio, Sigilo de dados: o direito à privacidade e os limites à função fiscalizadora do Estado, in Cadernos de Direito Constitucional e Ciência Política, ano 1, out/dez de 1992, p. p. $81-83$.
} 
dispositivo em apreço visa apenas a assegurar a inviolabilidade da relação comunicativa, isto é, tem por escopo impedir que um terceiro intercepte o fluxo da comunicação desses dados.

Conquanto essa seja a posição dominante no STF, entendemos não ser a mais correta. $\mathrm{E}$ assim entende a maior parte dos autores estudados. O inciso XII do artigo $5^{\circ}$ protege tanto o aspecto estático quanto o aspecto dinâmico dos dados. A norma não impede apenas a violação da relação comunicativa, mas também quer evitar a divulgação das informações por parte daqueles que as possuem. ${ }^{406}$

Posto isso, devemos observar que não procede a assertiva de que o sigilo de dados refere-se tão-somente à modalidade de comunicação, e não a seu objeto. Com efeito, o vocábulo "dado" sempre foi utilizado para indicar um informe acerca de algo. Caldas Aulete, em 1978, já mencionava que "dado" é "Indício, informação, antecedente por meio do qual se pode entrar no conhecimento de algum assunto". 407 Também no Dicionário Houaiss da Língua Portuguesa, fica claro que "dado" é a informação representativa de um fato, podendo referir-se a pessoas ou a qualquer outro fato: "11. informação relativa a indivíduo, capaz de identificá-lo (d. pessoais) (...) 16. informação capaz de ser processada por um computador". ${ }^{408}$

Observe-se que na acepção relativa à informática mencionada acima, o "dado" não é a forma pela qual uma informação é transmitida, mas sim a própria informação que está armazenada em um computador. Nesse sentido, Arnoldo Wald explica que com a revolução tecnológica, os papéis foram transformados em "dados" arquivados em computadores. Ocorre que essa situação facilita a devassa da privacidade dos titulares desses "dados", de modo que uma maior proteção faz-se necessária. ${ }^{409}$

\footnotetext{
${ }^{406}$ MorAES, Maurício Zanoide de, Sigilo Financeiro (LC 105/2001 e Dec. 3.724/200), in FrANCO, Alberto Silva e Stoco, Rui (coord.), Leis Penais e sua Interpretação Jurisprudencial, 7 ed. rev., atual. e ampl., São Paulo, Editora Revista dos Tribunais, 2001, p. 2990. Neste ponto é interessante afirmar que os registros das ligações telefônicas efetuadas e recebidas por um determinado indivíduo são considerados dados e, como tal, estão acobertados pelo sigilo aqui tratado e não pela inviolabilidade da comunicação telefônica.

${ }^{407}$ Dicionário contemporâneo da língua portuguesa - Vol II, p. 935.

${ }^{408}$ Dicionário Houaiss, disponível em http://houaiss.uol.com.br, acesso em 17.10.2009.

${ }^{409}$ WALD, Arnoldo, $O$ sigilo bancário no projeto de lei complementar de reforma do sistema financeiro e na lei complementar $n .^{\circ} 70$, in Cadernos de Direito Tributário e Finanças Públicas, n. ${ }^{\circ}$, ano 1 , out-dez de 1992, p. 206.
} 
Por derradeiro, é inaceitável restringir o alcance da proteção de um direito fundamental mediante uma técnica interpretativa. ${ }^{410}$. A Constituição protegeu o sigilo de dados expressamente e devemos entender que está a tutelar as informações representativas de fatos, porque são esses que merecem o devido resguardo. ${ }^{411}$ Nesse sentido:

“...não há dúvida de que o Texto Maior tutela, ao lado do sigilo da correspondência e das comunicações telegráficas e telefônicas, a inviolabilidade dos dados em si e não simplesmente da sua comunicação.

(...)

A reforçar essa orientação, não se pode perder de vista que o conteúdo dos dados também é protegido pelo direito à intimidade, previsto no art. $5^{o}, X, d a$ Constituição da República. ",12

Nesse sentido, Antonio Scarance Fernandes afirma que dados são os registros constantes do computador de um indivíduo, numa acepção mais estrita, e podem ser quaisquer anotações pessoais e reservadas, numa visão mais ampla. ${ }^{413}$

Todavia, da mesma forma que o direito à intimidade, como qualquer outra liberdade pública, não é ilimitado, outra não pode ser a conclusão acerca do sigilo de dados, embora essa não seja uma opinião unânime, nos termos do exposto no item anterior, haja vista a ressalva contida no inciso XII do artigo $5^{\circ}$, referindo-se apenas ao "último caso" dos sigilos ali elencados, dando a impressão de que os demais seriam absolutos.

\footnotetext{
${ }^{410}$ ChIAPPINI, Carolina e PeIXoto, Marcelo Magalhães, Sigilo bancário e fiscal no direito brasileiro, in Pizolio, Reinaldo e Gavaldão JR., Jayr Viégas (coord.), Sigilo fiscal e bancário, São Paulo, Quartier Latin, 2005 , p. 406.

411 CLÈVE, Clèmerson Merlin e SEHN, Solon, Crimes fiscais e sigilo bancário: pressupostos e limites constitucionais, in Heloisa Estellita Salomão (coord.), Direito Penal Empresarial, São Paulo, Dialética, 2001 , p. 61.

${ }^{412}$ Machado, André Augusto Mendes e KeHDI, Andre Pires de Andrade, Sigilo das comunicações e de dados..., p. 242-243.

${ }^{413}$ FERnANDES, Antonio Scarance, Processo Penal Constitucional..., p. 102.
} 
$\mathrm{Na}$ obra conjunta de Ada Pellegrini Grinover, Antonio Scarance Fernandes e Antonio Magalhães Gomes Filho, está consignada a opinião, de que a inviolabilidade do sigilo da correspondência, dados e comunicações telegráficas seria absoluta. ${ }^{414}$ Conclusão essa reiterada em textos individuais de Scarance ${ }^{415}$ e Ada Pellegrini, embora esta ressalte que a disposição deriva de um erro do constituinte ${ }^{416}$.

Entretanto, esclarecem os autores que para outra parcela da doutrina, o dispositivo em apreço cuidaria, de um lado, do sigilo da correspondência, e de outro, do sigilo das comunicações telegráficas, de dados e telefônicas, sendo que a ressalva para o último caso deve ser aplicada a todo este segundo grupo. Há, ainda, uma terceira posição, que entende que a exceção aplica-se não só às comunicações telefônicas, mas também ao sigilo de dados. Este foi o entendimento consolidado na Questão de Ordem da Petição n. ${ }^{\circ} 577 . .^{417}$

Observe-se que estamos diante de uma questão interpretativa. Há que se reconhecer que o legislador não foi feliz ao redigir o dispositivo em comento, e, sem dúvida, poderia ter sido mais esclarecedor. Aliás, segundo Ada Pellegrini Grinover, a Comissão de Redação exorbitou seus poderes e promulgou texto diverso do aprovado, acrescentando as palavras "comunicações", "no último caso" e "penal",418. Sendo assim, alternativa não nos resta exceto tentar dar ao dispositivo a melhor interpretação possível, coadunando o dispositivo constitucional com a realidade.

De fato, a melhor interpretação do inciso XII do artigo $5^{\circ}$ da Constituição Federal está com Ada Pellegrini Grinover, Antonio Scarance Fernandes e Antonio Magalhães Gomes Filho, que a ressalva refere-se apenas à hipótese das comunicações telefônicas. Porém, discordamos dos autores quando afirmam que o sigilo de dados é absoluto, pois nenhum direito individual pode ser considerado como tal. Nesse sentido, Luis Flávio

\footnotetext{
414 GrinOVER, Ada Pellegrini, FernAndes, Antonio Scarance, Gomes FILHO, Antonio Magalhães , As nulidades no processo penal..., p. 210.

${ }^{415}$ FERnANDES, Antonio Scarance, A Lei de Interceptação telefônica..., p. 54.

${ }^{416}$ Grinover, Ada Pellegrini, A marcha do Processo..., p. 104.

417 Grinover, Ada Pellegrini, FernAndes, Antonio Scarance, Gomes FILHo, Antonio Magalhães , As nulidades no processo penal..., p. 210.

${ }^{418}$ Grinover, Ada Pellegrini, A marcha do Processo..., p. 101.
} 
Gomes assevera que o sigilo de dados não pode ser considerado absoluto porquanto tal postura não se coaduna com a realidade e a necessidade da sociedade. ${ }^{419}$

Portanto, o sigilo dos bancos de dados pode sim ser afastado em situações excepcionais, respeitando o postulado da proporcionalidade, por se tratar de um direito fundamental. ${ }^{420}$ É imprescindível a existência de uma ordem judicial, uma vez que apenas o Poder Judiciário possui competência para limitar direitos constitucionais, avaliando a situação de fato e analisando se ela enquadra-se na hipótese legal. Apenas um juiz pode exercer um juízo de ponderação de maneira a decidir se a intervenção na esfera do segredo faz-se necessária, haja vista ser o único órgão público dotado de imparcialidade. ${ }^{421}$

Mais uma vez, encontramos hipótese de reserva de jurisdição absoluta. E assim podemos afirmar porque encontramos os três critérios capazes de submeter uma situação à reserva de jurisdição implícita: há uma controvérsia relevante; os interesses envolvidos são objeto de proteção constitucional; e um deles deverá sofrer restrição. ${ }^{422}$

Em havendo um direito fundamental envolvido, a intimidade, sua restrição não pode ser efetuada senão por meio de uma ordem judicial, por tudo o que já foi exposto. $\mathrm{O}$ fato de não haver expressa previsão constitucional ou legal acerca da necessidade de intervenção do Poder Judiciário não afasta sua exigência, pois esta emerge da natureza do direito envolvido, bem como da forma por meio da qual sua colisão com outros interesses deve ser solucionada.

\footnotetext{
${ }^{419}$ GOMES, Luis Flávio e CERVINI, Raúl, Interceptação telefônica: lei 9.296, de 24.07.96, São Paulo, Editora Revista Tribunais, 1997, p. 101. Maurício Zanoide de Moraes concorda com esse entendimento. Cf. Interceptação Telefônica..., p. 1794. Em outra obra, o autor afirma, ainda, que "Nenhum valor fundamental pode ser tido como abstrata e aprioristicamente superior a outros de igual envergadura." Ver Sigilo financeiro..., p. 2990.

${ }^{420}$ Moura, Maria Thereza Rocha de Assis, Meios de impugnação à quebra indevida de sigilo bancário, SAlOMÃo, Heloisa Estellita (coord.), in Direito Penal Empresarial, São Paulo, Dialética, 2001, p. 162-163. No mesmo sentido, Antonio Scarance Fernandes na obra Processo Penal Constitucional..., p. 102.

${ }^{421}$ BARROS, Marco Antonio de A busca da verdade no processo penal..., p. 272.

${ }^{422}$ Ver item 3.3.
} 


\subsubsection{QUEBRA DE SIGILO FINANCEIRO}

A relevância dos direitos fundamentais envolvidos no sigilo financeiro exige cautela e prudência do Poder Judiciário na determinação da ruptura da esfera de privacidade individual. ${ }^{423}$ Antes, contudo, de analisar esta restrição, cumpre tecer alguns comentários sobre a definição e proteção do instituto, o que é essencial para o entendimento acerca de sua natureza.

Todos os autores, de uma forma ou de outra, acabam por relacionar o conceito de sigilo financeiro à necessidade dos bancos manterem discrição quanto às informações obtidas no exercício de sua atividade. Para ilustrar tal assertiva, julgamos oportuna a transcrição da idéia que Raymond Farhat faz de sigilo bancário:

"...il s'agit d'une obligation juridique de discrétion incombant aux banques dans l'exercice de leur activité et bénéficiant aux personnes qui sont en rapport d'affaires avec elles". 424

Podemos fazer duas críticas a este conceito, que podem ser estendidas a diversos autores. A primeira é que diante da enorme variedade de instituições financeiras existentes hodiernamente, falar apenas em sigilo bancário, ou em obrigação dos bancos implica restringir demasiadamente seu alcance. Em face dessa situação, Maurício Zanoide de Moraes propôs a utilização da expressão sigilo financeiro para se referir ao dever de resguardo a que se submetem os membros do Sistema Financeiro Nacional ${ }^{425}$, no que já foi

\footnotetext{
${ }^{423}$ ZILLI, Marcos Alexandre Coelho, A iniciativa instrutória do juiz..., p. 206.

${ }^{424}$ Rivero, Jean, Les libertes publiques, $4^{\mathrm{a}}$ ed. Paris, Puf, 1989, p. 64. Traduzindo livremente, trata-se de uma obrigação jurídica de discrição imposta aos bancos no exercício de sua atividade em benefício das pessoas que mantêm relações de negócio com eles.

${ }^{425}$ MORAES, Maurício Zanoide de, Sigilo Financeiro..., p. 2979.
} 
seguido por autores como Juliana Belloque ${ }^{426}$, Carolina Chiappini e Marcelo Magalhães Peixoto. $^{427}$

Temos, assim, que o sigilo financeiro é o gênero do qual o sigilo bancário é espécie. $^{428}$ No entanto, esta última expressão já está intensamente arraigada tanto na doutrina quanto na jurisprudência, de maneira que, enquanto não houver uma adequação da linguagem, devemos entender que sua utilização constitui uma espécie de sinédoque, quando se faz menção à parte querendo referir-se ao todo.

Além disso, conquanto muitos autores falem em obrigação jurídica, parece-nos mais adequado falar em dever. Essa é a posição adotada por Juliana Belloque ${ }^{429}$, seguindo Maria Thereza Rocha de Assis Moura ${ }^{430}$, Ary Brandão de Oliveira ${ }^{431}$ e Miguel Reale ${ }^{432}$.

O importante é destacar, na esteira de Juliana Belloque, que, quando há a concretização de uma relação jurídica entre o cliente e a instituição financeira, realmente emerge uma obrigação jurídica. No entanto, o dever de sigilo não depende da relação contratual. $\mathrm{O}$ verdadeiro fundamento do sigilo financeiro é o direito à intimidade, o qual impõe o dever de discrição até mesmo com relação a informações prestadas por terceiros. $^{433}$

Conceituado o instituto, há que se indagar como ele é tratado na legislação brasileira. A doutrina diverge bastante no que tange à definição do dispositivo

\footnotetext{
${ }^{426}$ Belloque, Juliana, Sigilo bancário..., p. 66.

${ }^{427}$ ChiApPInI, Carolina e PEIXOTO, Marcelo Magalhães, Sigilo bancário e fiscal no direito brasileiro..., p. 402.

${ }^{428}$ MorAEs, Maurício Zanoide de, Sigilo Financeiro..., p. 2979.

${ }^{429}$ BeLloQUe, Juliana, Sigilo bancário..., p. 67.

${ }^{430}$ MourA, Maria Thereza Rocha de Assis, Meios de impugnação à quebra indevida de sigilo bancário..., p. 166 e nota 21.

431 OliveIRA, Ary Brandão de, Considerações acerca do segredo bancário, in Revista de Direito Civil, Imobiliário, Agrário e Empresarial, n. ${ }^{\circ}$ 23, ano 7, jan-mar, 1983, p. Considerações acerca do segredo bancário..., p. 115.

${ }^{432}$ ReAle, Miguel, Questões de direito público, São Paulo, Editora Saraiva, 1997, p. 124.

433 Belloque, Juliana, Sigilo bancário..., p. 67. O dever jurídico é imposto de maneira abstrata, enquanto que a obrigação depende da subsunção de uma relação de fato a uma norma jurídica para que possa surgir.Ver BRANDÃO, Ary de Oliveira, Considerações acerca do segredo bancário..., p. 115. Nesse sentido, cumpre mencionar que De Plácido e Silva, ao definir obrigação, refere-se a dois sentidos: o amplo corresponde à acepção de dever, quando se está sujeito a cumprir, fazer ou se abster de algo em virtude de um princípio superior; já o estrito corresponde à prestação que uma pessoa deve realizar em favor de outra em virtude de uma relação ou vínculo. Cf. Vocabulário jurídico - vol. III, 6a. ed., Rio de Janeiro, Forense, 1980, p. 1083.
} 
constitucional que confere proteção ao sigilo financeiro. Alguns defendem que seria apenas $\mathrm{o}$ inciso $\mathrm{X}$ do artigo $5^{\circ}$, em que o direito à intimidade é assegurado a todos. ${ }^{434}$ Outros acreditam que o inciso XII do mesmo artigo também fundamenta a proteção em comento ao garantir o sigilo de dados. ${ }^{435} \mathrm{E}$, como não poderia deixar de ser, há quem negue que a Carta Magna ampare qualquer tipo de segredo com relação aos dados bancários e financeiros em geral. ${ }^{436}$

Toda essa discussão advém do fato de a Constituição não fazer referência específica e tópica ao sigilo financeiro. Conquanto já se tenha tentado modificar esse quadro sob a égide da Constituição anterior, a proteção ao sigilo só pode ser extraída de nosso texto constitucional de forma indireta, o que gera algumas dúvidas acerca de qual dispositivo fundamenta-a.

Somos da opinião de que tanto o inciso X quanto o inciso XII do artigo $5^{\circ}$ da Constituição Federal servem de fundamento ao sigilo financeiro.

Não há como negar que o sigilo financeiro integra a vida privada dos indivíduos, bem tutelado pelo inciso $\mathrm{X}$ do artigo $5^{\circ}$ da Constituição de 1988. A privacidade não diz respeito apenas aos fatos pessoais, mas também aos patrimoniais, haja vista a tendência de reserva com relação aos bens materiais que vige no mundo de hoje. Não obstante, mediante a análise dos dados bancários ou do cartão de crédito da pessoa, por exemplo, é possível definir seus padrões de comportamento em diversos âmbitos, tais como o familiar, o sexual

\footnotetext{
${ }^{434}$ Pimenta, Paulo Roberto Lyrio, Possibilidade de Quebra do Sigilo Bancário pelo Fisco à Luz da Constituição Federal, in PIzolIO, Reinaldo e GAVALDÃo JR., Jayr Viégas (coord.), Sigilo fiscal e bancário, São Paulo, Quartier Latin, 2005, p. 97; SouZA, Hamilton Dias de, Sigilo Bancário e o direito à liberdade, in Revista Tributária e de Finanças Públicas, n. ${ }^{\circ}$ 30, ano 8, jan-fev, 2000, p. 140; GRAMSTRUP, Erik Frederico, Sigilo Fiscal e Bancário: fundamentos normativos e principiológicos da quebra, in Pizolio, Reinaldo e GAVALDÃo JR., Jayr Viégas (coord.), Sigilo fiscal e bancário, São Paulo, Quartier Latin, 2005, p. 228. Essa também é a opinião que predomina no Supremo Tribunal Federal, por acreditarem que o inciso XII resguarda apenas a comunicação dos dados. Ver STF MS 23.452-1, Rel. Min. Celso de Mello, DJ de 12.05.2000.

${ }^{435}$ REALE, Miguel e Martins Ives Gandra da Silva, Sigilo bancário: inconstitucionalidade do Decreto $n$. 4.489 de 28/11/2002 por macular o processo legislativo plasmado na lei suprema e infringir direitos fundamentais do cidadão - opinião legal, in Pizolıo, Reinaldo e GAVALDão JR., Jayr Viégas (coord.), Sigilo fiscal e bancário, São Paulo, Quartier Latin, 2005, p. 71; GOMES, Luis Flávio, Crimes fiscais e sigilo bancário: pressupostos e limites constitucionais, in SALOMÃo, Heloisa Estellita (coord.), Direito Penal Empresarial, São Paulo, Dialética, 2001, p. 155-156; MORAES, Maurício Zanoide de, Sigilo Financeiro..., p. 2990; entre outros.

${ }^{436}$ SARAIVA FILHO, Oswaldo Othon de Pontes, $O$ acesso direito aos dados bancários por parte do fisco: a transferência do sigilo bancário para o sigilo fiscal, in PIZOLIO, Reinaldo e GAVALDÃo JR., Jayr Viégas (coord.), Sigilo fiscal e bancário, São Paulo, Quartier Latin, 2005, p. 144.
} 
e o religioso. Assim, como bem acentuou Juarez Tavares ${ }^{437}$, dentro das esferas da vida privada, o sigilo financeiro encontra-se na mais restrita possível, a do segredo. Todavia, interessa ressaltar que tal fato não altera em nada a proteção constitucional, uma vez que a Constituição tutela a vida privada de modo amplo. É esclarecedor o seguinte trecho do artigo do autor:

"Somente pessoas muito ligadas ao titular da conta, afora, está claro, os funcionários encarregados de mantê-la, é que alcançam o conhecimento acerca de seu numerário, seu movimento, suas entradas e retiradas, suas aplicações, a origem do dinheiro e seu destino. O sigilo bancário, portanto, não é um simples instrumento de prática bancária, destinado a agilizar ou perpetuar seus negócios, mas uma extensão da proteção da vida privada, inserida como direito fundamental do cidadão. O sigilo não é do banco, é do homem que utiliza o banco, que com ele negocia". 438

Entretanto, não é apenas do inciso $\mathrm{X}$ do artigo $5^{\circ}$ que emerge o status de direito fundamental do sigilo financeiro. Prescreve o inciso XII:

"XII - é inviolável o sigilo da correspondência e das comunicações telegráficas, de dados e das comunicações telefônicas, salvo, no último caso, por ordem judicial, nas hipóteses e na forma que a lei estabelecer para fins de investigação criminal ou instrução processual penal;"

437 TAVARES, Juarez, A violação ao sigilo bancário em face da proteção da vida privada, in Revista Brasileira de Ciências Criminais, ano 1, jan/mar, 1993, p. 106.

${ }^{438}$ Idem, p. 106-107. 
Conquanto existam posições divergentes, ${ }^{439}$, entendemos que o inciso XII do artigo $5^{\circ}$ protege tanto o aspecto estático quanto o aspecto dinâmico dos dados, conforme já afirmamos no item anterior. A norma não impede apenas a violação da relação comunicativa, mas também quer evitar a divulgação das informações por parte daqueles que as possuem, o que nos leva à conclusão de que o inciso XII também protege o sigilo financeiro. $^{440}$

Se considerarmos apenas a proteção conferida pelo inciso $\mathrm{X}$ do artigo $5^{\circ}$ da $\mathrm{CF}$, não nos deparamos com qualquer previsão de como deve ser feita eventual restrição ao direito à intimidade. Conseqüentemente, numa hipótese em que o sigilo financeiro, decorrente desse amparo, tiver que ser afastado, estaremos diante de uma situação de reserva de jurisdição implícita.

Isso porque, conforme explicado no item 3.3., ao se constatar uma circunstância em que um direito fundamental deve ser limitado por colidir com outro interesse constitucionalmente protegido sem que haja previsão legal de como tal intervenção deve se operacionalizar, a atuação do Poder Judiciário será inafastável de qualquer maneira, revelando uma situação de reserva de jurisdição absoluta implícita. ${ }^{441}$

Poder-se-ia argumentar, entretanto, que a ressalva presente no inciso XII, acerca da possibilidade de restrição das comunicações telefônicas desde que haja ordem judicial, deveria ser estendida à limitação do sigilo de dados. Conforme consignado anteriormente, trata-se de um típico caso de reserva de jurisdição absoluta constitucional, explicitamente prevista no texto maior. Neste caso, haveria uma previsão expressa de sujeição do sigilo financeiro à reserva de jurisdição, mas não consideramos o melhor entendimento.

\footnotetext{
${ }^{439}$ Essa observação é feita por Ives Gandra e Miguel Reale, que também ressaltam o fato de não haver consenso entre os Ministros sobre o assunto. Cf. Sigilo bancário: inconstitucionalidade do Decreto $n^{\circ}{ }^{\circ}$ 4.489..., p. 53. A ementa do Mandado de Segurança n. ${ }^{\circ}$ 23.452-1, Rel. Min. Celso de Mello, DJ de 12.05.2000 do STF revela a vertente que prevaleceu: " O sigilo bancário, o sigilo fiscal e o sigilo telefônico (...) - ainda que representem projeções específicas do direito à intimidade, fundado no art. $5^{\circ}, X$ da Carta Política (...)"

${ }^{440}$ MORAES, Maurício Zanoide de, Sigilo Financeiro..., p. 2990.

${ }^{441}$ Entendemos ser desnecessário, neste ponto, retomar a idéia de aplicação do postulado da proporcionalidade, em virtude da natureza dos interesses contrastantes, bem como da imperiosidade da observância do devido processo legal e do núcleo essencial da função jurisdicional. Entenda-se, todavia, que, ao nos remetermos ao item 3.3., estamos nos referindo a todos esses fatores já estudados. Observe-se, ainda, que a aplicação do postulado da proporcionalidade implica a observância de diversos subprincípios e requisitos na quebra do sigilo bancário. Contudo, dado ser a reserva de jurisdição o tema central do estudo, demos a ela especial enfoque.
} 
A melhor interpretação do inciso XII do artigo $5^{\circ}$ da Constituição Federal é feita por Ada Pellegrini Grinover, Antonio Scarance Fernandes, Antonio Magalhães Gomes Filho e Ives Gandra Martins, os quais afirmam que a ressalva refere-se apenas à hipótese das comunicações telefônicas. Todavia, ao contrário dos autores, não entendemos que a inviolabilidade dos dados é absoluta.

Os direitos individuais não podem ser considerados absolutos. ${ }^{442}$ Nesse sentido, numerosos são os julgados que reconhecem a relatividade dos direitos fundamentais, nomeadamente, do sigilo financeiro. ${ }^{443}$

Considerar que o sigilo de dados é absoluto inviabilizaria a efetivação de outros direitos para os quais a quebra de sigilo financeiro se mostra indispensável. Nesse sentido, Luis Flávio Gomes assevera que o sigilo de dados não pode ser considerado absoluto porquanto tal postura não se coaduna com a realidade e a necessidade da sociedade. ${ }^{444}$

Essas conclusões apresentam-se em perfeita sintonia com o que expusemos acerca da reserva de jurisdição implícita, a qual se mostra necessária para a resolução de tais conflitos.

No caso do sigilo financeiro, nas situações em que pode ser afastado, dizemos que ocorre sua quebra. Por restringir um direito de tamanha relevância, Juliana Belloque afirma que a quebra de sigilo financeiro é uma medida de coação que tem por escopo garantir a prova criminal. Sua validade depende da observância de pressupostos e requisitos legais e constitucionais, tendo em vista sua excepcionalidade. ${ }^{445}$

A autora explica que a medida deve ser deferida pelo juiz, e concretiza-se mediante duas etapas. Na primeira, o direito à inviolabilidade do sigilo financeiro é afastado e, na

\footnotetext{
${ }^{442}$ GRINOVER, Ada Pellegrini, Liberdades públicas..., p. 88.

443 STF, MS n. ${ }^{\circ}$ 23.453-1, RJ, Rel., Min. Celso de Mello, Tribunal Pleno, DJ 12.05.2000; STF MS 21.729-4, DF, Rel., Ministro Marco Aurélio, Tribunal Pleno, DJ 10.10.2001; STF, Questão de Ordem da Petição 5775, DF, Rel., Min. Carlos Veloso, DJ 23.04.93.

${ }^{444}$ GOMES, Luis Flávio e CERVINI, Raúl, Interceptação telefônica..., p. 101. Maurício Zanoide de Moraes concorda com esse entendimento. Cf. Interceptação Telefônica (L. 9.296/96)..., p. 1794. Em outra obra, o autor afirma, ainda, que "Nenhum valor fundamental pode ser tido como abstrata e aprioristicamente superior a outros de igual envergadura.” Ver MORAES, Maurício Zanoide de, Sigilo Financeiro..., p. 2990. ${ }^{445}$ Belloque, Juliana, Sigilo bancário..., p. 86.
} 
segunda, é determinado o apossamento dos papéis contendo os dados sigilosos, que, posteriormente, são levados ao processo como prova documental. ${ }^{446}$

A quebra do sigilo financeiro é um meio de obtenção de prova que se traduz por uma medida de coação, haja vista que para se concretizar acaba por restringir um direito fundamental, qual seja, o direito à intimidade. Essa restrição só é possível porquanto este direito constitucionalmente protegido entra em conflito com um bem também constitucionalmente protegido, o interesse da investigação criminal, que deve ser atendido para que o Estado possa exercer seu direito de punir. Mais uma vez, extraímos do exposto que estamos diante de um típico caso de reserva de jurisdição implícita. ${ }^{447}$

Apesar de todo o exposto, a Lei Complementar n. ${ }^{\circ}$ 105/2001 veio permitir expressamente que as Comissões Parlamentares de Inquérito e a administração tributária requisitassem diretamente às instituições financeiras as informações sigilosas das quais são detentoras. Ora, sendo o Poder Judiciário o único vocacionado para decidir acerca da restrição de direitos fundamentais num caso concreto, qualquer outra autoridade que o faça estará praticando um ato inconstitucional. A mesma conclusão se aplica ao diploma legal que traz essa previsão, porquanto contraria a ordem constitucional do país.

\footnotetext{
446 A medida de coação é excepcional, pois para que seja perpetrada ocorre uma restrição de direito fundamental, o que só se dá extraordinariamente e para preservar um outro interesse de grande relevância, no caso, a instrução criminal. BELloQUE, Juliana, Sigilo bancário..., p. 87.

${ }^{447}$ Infelizmente, nossos tribunais ainda são muito resistentes a essa idéia. Prova disso é o julgamento da Ação Cautelar n. ${ }^{\circ} 33$ do STF. A última movimentação, publicada por meio do Informativo STF n. ${ }^{\circ}$ 572, datada de 18.12.2009, é de que falta apenas um voto para que o Superior Tribunal Federal reconheça ao Fisco o direito de quebra do sigilo bancário. Até então, cinco Ministros já haviam votado favoravelmente ao Fisco, enquanto apenas três foram favoráveis à reserva de jurisdição. Isso significa que se mais um dos três ministros faltantes votarem a favor do indeferimento do efeito suspensivo dado ao recurso extraordinário que discute a questão, a administração tributária sairá vencedora na disputa.
} 


\subsubsection{OUTRAS MEDIDAS RESTRITIVAS DE DIREITOS FUNDAMENTAIS}

No desenrolar da atividade instrutória, muitos outros meios de obtenção de prova, ou mesmo meios de prova que ensejam intervenções a direitos dos acusados, podem ser levadas a cabo.

Teresa Armenta Deu menciona, por exemplo, a possibilidade de inspeções ou intervenções corporais, que são atentados à integridade física do indivíduo na medida em que implicam a retirada de alguma parte do corpo para submetê-la a exame. Segundo a autora, por se tratar de medida limitativa de direitos fundamentais, exige, para sua concretização, a existência de uma decisão judicial que observe o postulado da proporcionalidade. $^{448}$

O exame de DNA ilustra bem essa hipótese. Não se pode coagir um indivíduo que não se dispõe a colaborar espontaneamente a ceder amostra de seu sangue ou fio de cabelo sem uma decisão judicial, pois se trata de interferência a sua integridade física. No âmbito de uma CPI, é possível que tal medida seja necessária para comprovar um eventual caso de nepotismo, por exemplo.

Lembre-se, ainda, da situação já aventada no item 4.2., relativa ao sigilo fiscal que envolve um processo administrativo tributário. Nele, estão registradas informações atinentes ao patrimônio do contribuinte e, conseqüentemente, a sua intimidade. Assim, no caso de sua cópia ser acostada a algum processo como documento apto a demonstrar algum fato, haverá a realização de um meio de prova que afeta direito fundamental. Logo, a decisão judicial prévia será medida imperiosa em virtude de tudo o que já foi exposto sobre a reserva de jurisdição.

${ }^{448}$ DeU, Teresa Armenta ,Leciones de Derecho Procesal Penal..., p. 158-160. 


\section{COMISSÕES PARLAMENTARES DE INQUÉRITO}

Nos termos do que foi exposto na introdução desta obra, é nosso objetivo entender o instituto da reserva de jurisdição no ordenamento brasileiro, suas justificativas, critérios de utilização e sua relação com algumas medidas restritivas de direito, especificamente no Processo Penal e, ao final, fazer um estudo de caso, aplicando-se as conclusões alcançadas ao funcionamento das Comissões Parlamentares de Inquérito, visando a estabelecer os alicerces para a análise crítica acerca de seus poderes investigatórios.

Antes, porém, de adentrar ao cerne da questão, isto é, de tratar do alcance dos poderes de investigação das Comissões Parlamentares de Inquérito, é indispensável entender a dinâmica deste mecanismo existente no âmbito do poder legislativo com o escopo de investigar fatos de interesse público. ${ }^{449}$

Sendo assim, faremos uma breve digressão acerca das Comissões Parlamentares de Inquérito, tarefa fulcral para a melhor interpretação do $\S 3^{\circ}$ do artigo 58 da Constituição Federal brasileira.

\subsection{O PODER LEGISLATIVO E A FUNÇÃO DE CONTROLE}

Já dissemos no item 2.5.2.2. que ao Poder Legislativo incumbe fiscalizar e controlar os atos do Poder Executivo e julgar a prestação de contas do Presidente da República (incisos IX e X do artigo 49 da CF de 1988), e não apenas elaborar as normas jurídicas, como pode parecer.

Aliás, segundo Luiz Carlos dos Santos Gonçalves o controle do poder e representação popular eram justamente as funções originárias exercidas pelos órgãos

${ }^{449}$ Embora seja possível instituir Comissões Parlamentares de Inquérito no âmbito de todos os entes federativos, nossa análise ficará restrita ao âmbito federal, para que não haja dispersão do tema proposto. 
compostos por representantes da população e controlar o cumprimento da lei por parte dos órgãos públicos é tão relevante quanto legislar. Atualmente, no Brasil, esse controle pode ser exercido de diversas maneiras, tais como a aprovação de contas pelo Congresso Nacional, por órgãos a ele vinculados, como o Tribunal de Contas, ou pela atuação das Comissões Parlamentares de Inquérito. ${ }^{450}$

Ángel Luis Alonso de Antonio e José Antonio Alonso de Antonio afirmam que em uma Constituição Democrática encontram-se diversas formas de controle, sendo que o controle que o Parlamento exerce sobre o governo é da espécie político, uma vez que se utiliza o critério de oportunidade e, conseqüentemente, implica uma valoração subjetiva. Segundo os autores, este controle pode ser exercido de maneiras diferentes, orientando o governo por meio da fixação de posturas; inspecionando suas atividades continuamente; e aplicando sanções quando necessário. Dentre as formas de "controle-inspeção" encontramse as Comissões de Investigação, que consistem em órgãos parlamentares colegiados e temporários que investigam um assunto de interesse público para avaliar a responsabilidade política ou jurídica. ${ }^{451}$

Canotilho também destaca a função política de controle como uma das mais importantes exercidas pelo Poder Legislativo e esclarece que ela não se relaciona apenas com os mecanismos parlamentaristas, existindo também em sistemas presidencialistas. Ainda, ao enumerar as formas pelas quais tal função se expressa, cita os inquéritos, levados

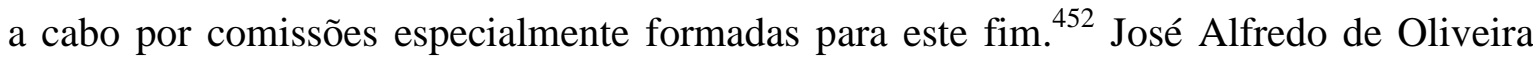
Baracho vai além, afirmando que as Comissões Parlamentares de Inquérito são um dos instrumentos mais prestigiados utilizados pelo Legislativo para exercer o controle político sobre o Executivo. ${ }^{453}$

Luiz Carlos dos Santos Gonçalves, por sua vez, faz um esforço interpretativo para diferenciar controle e investigação, o que não é feito pelos demais estudiosos. $\mathrm{O}$ autor

\footnotetext{
450 GonÇAlVes, Luiz Carlos dos Santos, Poderes de Investigação das Comissões Parlamentares de Inquérito..., p. 14-15; CARAJELESCOV, Yuri, Comissões Parlamentares de Inquérito..., p. 58.

${ }^{451}$ AnTONIO, Ángel Luis Alonso de e ANTONIO, José Antonio Alonso de, Derecho Constitucional Español..., p. $465-474$.

${ }_{452}$ CANOTILHO, José Joaquim Gomes, Direito constitucional e teoria da constituição..., p. 635-636.

${ }^{453}$ BARACHO, José Alfredo de Oliveira, As Comissões Parlamentares na Constituição de 1988, in Revista de Direito Mackenzie, ano 3, n. ${ }^{\circ}$ 1, São Paulo, 2002, p. 54.
} 
esclarece que, para ele, ambos são espécies da fiscalização, tarefa atribuída genericamente ao Poder Legislativo e que pode se concretizar de diversas maneiras.

Aquelas atividades relacionadas ao exame de contas do Executivo ou auxílio ao Tribunal de Contas são direcionadas à verificação da pertinência de certas atuações com a Constituição ou com as leis e dizem respeito à função de controle. Já aquelas que necessitam de um processo de obtenção de informações e que podem ensejar a responsabilização de agentes, são as atividades de investigação. ${ }^{454}$

Evidenciada a essência da Comissão Parlamentar de Inquérito, que existe para operacionalizar uma das funções do Poder Legislativo, a de controle das atividades exercidas no âmbito do Estado de Direito, passemos a apresentar detalhadamente as características do órgão.

Antes, porém, é interessante diferenciar as diferentes espécies de comissões que existem no âmbito do Poder Legislativo, de sorte a evitar confusões.

\subsection{COMISSÕES PARLAMENTARES DE INQUÉRITO - CONCEITO E ESSÊNCIA}

Paulo Hamilton Siqueira Junior faz uma análise semântica da expressão Comissão Parlamentar de Inquérito, na qual afirma que a palavra comissão vem do latim, comissione, que designa um grupo de pessoas reunidas para uma determinada tarefa. Sobre parlamentar, diz que o termo parlamento, em francês, indica a assembléia que fala, que delibera. Por fim, o termo inquérito, também do latim, inquaeritare, significa inquirir, procurar, apurar. ${ }^{455}$

Aplicando essas conclusões nominais ao âmbito do Direito Processual Constitucional, o autor chega a uma definição do instituto:

\footnotetext{
454 GonçAlves, Luiz Carlos dos Santos, Poderes de Investigação das Comissões Parlamentares de Inquérito..., p. 41.

${ }^{455}$ SIQUeIRA JR., Paulo Hamilton, Comissão Parlamentar de Inquérito..., p. 4-5.
} 
“...a Comissão Parlamentar de Inquérito é o procedimento jurídico constitucional exercido pelo Poder Legislativo com a finalidade investigativa dos fatos de interesse público. "456

$\mathrm{Na}$ seara da função de controle exercida pelo Parlamento, as Comissões Parlamentares de Inquérito servem, sem dúvida alguma, à fiscalização dos atos do Poder Público, investigando irregularidades, abusos ou distorções. As investigações por elas perpetradas, todavia, possuem natureza sui generis, quer dizer, são diferentes de todos os demais procedimentos similares existentes em nosso ordenamento, tais como inquérito policial e Processo Penal. Isso significa que, embora possam emprestar algumas normas, as Comissões Parlamentares de Inquérito devem ter regras específicas. ${ }^{457}$

As CPIs não têm a natureza preparatória própria dos inquéritos, sejam penais, sejam civis. Não têm como objetivo central lastrear a propositura de ações, embora tal providência possa advir de suas atividades como resultado secundário. Da mesma forma, o estudo para alterações legislativas não é seu escopo principal, mas pode ser uma conseqüência. Ora, levando em consideração que o Poder Legislativo exerce duas funções, a legislativa e a fiscalizatória, não parece adequado só permitir o exercício de uma delas, a fiscalização, se houver interesse na prática da outra, produção de leis. ${ }^{458}$

Assim, segundo Luiz Carlos dos Santos Gonçalves, a finalidade das Comissões Parlamentares de Inquérito é:

\footnotetext{
${ }^{456}$ SIQUEIRA JR., Paulo Hamilton, Comissão Parlamentar de Inquérito..., p. 5.

${ }^{457}$ SiQueIRa JR., Paulo Hamilton, Comissão Parlamentar de Inquérito..., p. 9; e GonçALves, Luiz Carlos dos Santos, Poderes de Investigação das Comissões Parlamentares de Inquérito..., p. 40.

${ }^{458}$ SiQueIRA JR., Paulo Hamilton, Comissão Parlamentar de Inquérito..., p. 9; GonÇALVES, Luiz Carlos dos Santos, Poderes de Investigação das Comissões Parlamentares de Inquérito..., p. 40 e 58.
} 
"apurar o fato certo e determinado para o qual foram constituidas, em exercício de prerrogativa diretamente ligada ao papel político do Congresso Nacional no acompanhamento dos assuntos nacionais", 459

Esta atividade tem, portanto, estrita relação com o poder de representação parlamentar e não permite a imposição de medidas decorrentes de suas conclusões, pois não há poder jurisdicional envolvido, uma vez que sua natureza jurídica é de procedimento político-administrativo. ${ }^{460}$

Nesse sentido, Rogerio Lauria Tucci esclarece que a investigação levada a cabo no âmbito das CPIs tem natureza de inquérito parlamentar em sentido estrito ou políticoadministratrivo. Sua natureza é administrativa, e sua finalidade é meramente investigatória, quer dizer, obter dados e informações sobre os fatos investigados. ${ }^{461}$

Eventualmente, como já dito, podem ser enviadas conclusões aos órgãos competentes para que estes tomem as providências cabíveis, daí podem surgir ações penais ou cíveis. Por outro lado, podem ser sugeridas alterações legais ou elaborações de novos textos normativos. Nesse sentido, é um instrumento de caráter político que auxilia o aprimoramento da democracia, tendo como finalidade precípua o alcance do bem comum da coletividade, investigando fatos que influenciem sua qualidade de vida, além de ser uma ferramenta utilizada pela minoria parlamentar. ${ }^{462}$

Como será dito no item 5.3.1., o requerimento para criação de uma CPI deve ser subscrito por um terço dos membros da casa legislativa a que se refere, de forma que sua instauração poderá ser provocada por uma parcela minoritária da mesma. É certo que o

\footnotetext{
459 GonçAlves, Luiz Carlos dos Santos, Poderes de Investigação das Comissões Parlamentares de Inquérito..., p. 40-41.

${ }^{460}$ Gonçalves, Luiz Carlos dos Santos Gonçalves, Poderes de Investigação das Comissões Parlamentares de Inquérito..., p. 41.

461 Ao lado do inquérito parlamentar propriamente dito, realizado pelas CPIs, existem, ainda, o inquérito parlamentar administrativo e o parlamentar judicial que podem recomendar aplicações de penas ou medidas disciplinares, o que é vedado no bojo do primeiro. TuCCI, Rogério Lauria, Comissão Parlamentar de Inquérito..., p. 174-175.

${ }^{462}$ SiQueIRA JR., Paulo Hamilton, Comissão Parlamentar de Inquérito..., p. 14; GonÇALVES, Luiz Carlos dos Santos, Poderes de Investigação das Comissões Parlamentares de Inquérito..., p. 41; BARACHO, José Alfredo de Oliveira, As Comissões Parlamentares na Constituição de 1988..., p. 43.
} 
quorum exigido poderia ser menor para que a garantia de fiscalização por parte da minoria fosse mais eficaz, mas a dispensa da deliberação plenária já permite um maior controle dos atos do Executivo. ${ }^{463}$

Ademais, não se deve perder de vista que, em virtude da atribuição excepcional de poderes incomuns ao Poder Legislativo que possuem as CPI, a imposição de requisitos rígidos para sua instauração é fundamental. Rogerio Lauria Tucci denomina essa característica de extraordinariedade, pois essas comissões só podem ser criadas em circunstâncias especiais. ${ }^{464}$

Nessa conjuntura, e por ser um procedimento, o desenrolar dos trabalhos de uma Comissão Parlamentar de Inquérito deve atender a alguns pressupostos processuais para que seja válido. Paulo Hamilton Siqueira Junior divide esses pressupostos em processuais constitucionais (requerimento qualificado; fato determinado; prazo certo) e constitucionais intrínsecos (competência; correlação entre objeto do requerimento e investigação). ${ }^{465}$ Passamos a analisá-los.

\subsection{PRESSUPOSTOS}

\subsubsection{REQUERIMENTO QUALIFICADO}

Exige-se um quorum qualificado para se requerer a instalação de uma Comissão Parlamentar de Inquérito. A qualificação diz respeito à existência de uma fração determinada, mas não implica a adesão da maioria, tampouco aprovação em plenário, uma vez que o quorum constitucional é de um terço. A Constituição Portuguesa é mais

${ }^{463}$ GonçAlves, Luiz Carlos dos Santos, Poderes de Investigação das Comissões Parlamentares de Inquérito..., p. 41.

${ }^{464}$ Comparato, Fabio Konder, Comissões Parlamentares de Inquérito - Limites, in Revista Trimestral de Direito Público, n. ${ }^{\circ}$ 5, Malheiros Editores, 1994, p. 69; TuCCI, Rogério Lauria, Comissão Parlamentar de Inquérito..., p. 175.

${ }^{465}$ SiqueIRA JR., Paulo Hamilton, Comissão Parlamentar de Inquérito..., p. 41-42. 
condescendente neste ponto, exigindo que o requerimento seja feito por apenas um quinto dos parlamentares, o que lhe dá um viés mais democrático. ${ }^{466}$ Isso porque:

"Em um regime democrático, não se pode olvidar que a fiscalização política dos atos de governo é exercida, embora não exclusivamente, pelas minorias parlamentares oposicionistas, e por isso se afigura coerente a opção abraçada pelos constituintes portugueses e brasileiros no sentido de dotar essas minorias parlamentares qualificadas da prerrogativa de, uma vez preenchidos os requisitos constitucionais mínimos, deflagrar o processo de investigação parlamentar. "467

Por tal razão designam-se as Comissões Parlamentares de Inquérito como instrumento de controle da minoria, o que está atrelado ao direito de oposição, característica exclusiva dos regimes democráticos, que os diferencia dos autoritários. ${ }^{468}$

Todavia, um problema operacional se apresenta. Feito o requerimento de instauração da CPI, a indicação dos membros que dela farão parte passa a ser tarefa dos líderes das bancadas legislativas, o que acaba devolvendo aos grupos majoritários o controle da investigação. Deve-se observar, contudo, o princípio da representação proporcional dos partidos, nos termos que o $\S 1^{\circ}$ do artigo 58 da CF consagra com relação às comissões parlamentares de forma genérica. ${ }^{469}$

A solução encontrada foi estabelecer um prazo para o exercício dessa prerrogativa e, no caso de não haver a indicação devida, é o Presidente da Casa que deve fazê-la. É claro que este também pode se abster e, num caso similar, o STF já se pronunciou,

\footnotetext{
466 SiqueIRA JR., Paulo Hamilton, Comissão Parlamentar de Inquérito..., p. 43; CARAJELESCOV, Yuri, Comissões Parlamentares de Inquérito..., p. 75.

${ }^{467}$ CARAJElescov, Yuri, Comissões Parlamentares de Inquérito..., p. 78.

${ }^{468}$ Idem, p. 79-80. É claro que a instauração de CPIs não é a única forma pela qual se traduz o direito de oposição, que também pode ser exercido por meio de ONGs, sindicatos, entre outras entidades. V. op. cit., p. 83.

${ }^{469}$ CASSEB, Paulo Adib, Controle governamental exercido pelo legislativo..., p. 25.
} 
reconhecendo às minorias o direito de instauração de comissão investigativa sem qualquer obstáculo. ${ }^{470}$

Feitas as devidas considerações acerca do quorum do requerimento, bem como sua relevância na prática democrática, há que se destacar a necessidade da Presidência do Parlamento proceder a um exame meramente formal do requerimento, verificando de forma perfunctória a presença cumulativa dos pressupostos constitucionais exigidos para a instauração da CPI. Se forem atendidos, o requerimento será publicado e a Comissão estará formada. ${ }^{471}$

Dito isto, passemos à análise dos demais pressupostos.

\subsubsection{FATO DETERMINADO}

A exigência de que se investiguem fatos determinados visa a afastar averiguações de alegações abstratas, restringindo-as a acontecimentos concretos e estritamente definidos, evitando-se, também, objeto demasiadamente amplo. Assim, não se pode investigar, aleatoriamente, fatos da sociedade de forma genérica, na esperança de se encontrar alguma irregularidade, pois tal conduta implicaria a configuração de abuso de poder parlamentar. ${ }^{472}$

\footnotetext{
${ }^{470}$ MS 24.831-9, DF, Rel. Min. Celso de Mello, DJ 22.06.2005, citado em CARAJELESCov, Yuri, Comissões Parlamentares de Inquérito..., p. 83-84.

${ }^{471}$ Idem, p. 86 e 102. Os pressupostos constitucionais são número mínimo de adesões (um terço), prazo certo para conclusão dos trabalhos, fato determinado com envolvimento de interesse público e inserido no âmbito das competências da Casa legislativa em questão.

${ }^{472}$ SiqueIRA JR., Paulo Hamilton, Comissão Parlamentar de Inquérito..., p. 49; GonÇALVES, Luiz Carlos dos Santos, Poderes de Investigação das Comissões Parlamentares de Inquérito..., p. 135; Comparato, Fabio Konder, Comissões Parlamentares de Inquérito..., p. 70; CASSEB, Paulo Adib, Controle governamental exercido pelo legislativo..., p. 25; BADARÓ, Gustavo Henrique Righi Ivahy, Limites aos poderes investigatórios das comissões parlamentares de inquérito, in Boletim IBCCRIM, São Paulo, v. 7, $\mathrm{n}^{\circ} 83$ (esp.), out. 1999, p. 11-12.
} 
São necessários indícios suficientemente fortes da ocorrência dessa irregularidade sem se exigir, entretanto, que todas as sutilezas e minúcias do fato estejam determinadas no requerimento de instauração da Comissão. Há que se lidar com a idéia de razoabilidade. ${ }^{473}$

Contudo, fato certo e determinado não deve significar fato único, quer dizer, a comissão poderá investigar outros fatos, que não aquele que ensejou sua criação, desde que envolvam interesse público; que estejam estritamente relacionados com o núcleo da apuração, havendo uma relação de causa e efeito entre eles; e que estejam inseridos no âmbito de competência do parlamento em que ela esteja ocorrendo. ${ }^{474} \mathrm{Se}$ assim não fosse, estaríamos, novamente, sujeitos a abuso de poder. Interessante a transcrição do seguinte excerto sobre a determinação do objeto de investigação:

“(...) a delimitação clara e precisa do objeto das investigações parlamentares, por imperativo constitucional, impede que tais órgãos criados ad hoc se transformem em instrumentos de devassas ou que passem a proceder ao exame indiscriminado de documentos ou testemunhas acerca de fatos indeterminados, tendências, opiniões e ideologias (...).,"475

Para tanto, dois aspectos deverão ser observados: no plano da existência, o fato deve ter comprovadamente ocorrido; já no plano da legalidade, o fato deve configurar uma irregularidade, seja ela penal, civil ou administrativa. ${ }^{476}$ Nesse sentido:

"O requerimento da Comissão Parlamentar de Inquérito deve detalhar o fato ou fatos e determiná-los. A indicação precisa do fato é condição sine qua non para a investigação, pois a falta de objetividade do fato acarreta a ineficácia das

\footnotetext{
${ }^{473}$ RIANI, Frederico Augusto D’Avila, Comissão Parlamentar de Inquérito: Requisitos para criação, objeto e poderes, in Revista do Instituto de Pesquisas e Estudos - Divisão Jurídica, Instituição Toledo de Ensino Bauru, Dez 1999 a Mar 2000, p. 338.

${ }_{474}$ CARAJElESCOV, Yuri, Comissões Parlamentares de Inquérito..., p. 448.

${ }^{475}$ Idem, p. 107-108.

${ }^{476}$ SIQUEIRA JR., Paulo Hamilton, Comissão Parlamentar de Inquérito..., p. 53.
} 
investigações. A verificação desse pressuposto comporta duas condições: a existência do fato e sua ilegalidade. A existência do fato é importante na medida em que não se admite a investigação in abstrato. A ilegalidade deve estar presente, pois o ato investigado deve ser irregular. "477

A indispensabilidade da ilegalidade do ato não implica, entretanto, que a investigação seja feita com o escopo de responsabilização, seja ela cível ou criminal. Não há que se limitar a investigação a identificar autoria e materialidade da conduta, sendo possível a apuração de toda a conjuntura que ensejou a ocorrência da ilicitude. ${ }^{478}$

Fabio Konder Comparato alerta para o fato de que embora a exigência de que o fato investigado deve guardar relação com o interesse público não seja expressa no texto constitucional relativo às CPIs, em virtude dos poderes coercitivos a elas conferidos, devemos entender que está implícita na norma do artigo 58 da CF. Deve haver alguma ligação com as entidades da Administração Pública para justificar a investigação parlamentar, não sendo permitida, portanto, a investigação da vida familiar de um cidadão. $^{479}$

Luiz Carlos dos Santos Gonçalves indaga, ainda, acerca da natureza dos fatos que podem ser submetidos às Comissões Parlamentares de Inquérito, se está impedida a investigação relativa a fatos particulares. Existem opiniões que defendem ambas as possibilidades, mas estamos com o autor quando afirma que os fatos particulares também podem ser investigados, desde que não sejam exclusivamente privados, isto é, deve haver ligação com situação de interesse público relevante. ${ }^{480}$

\footnotetext{
${ }^{477}$ SIQUeIRA JR., Paulo Hamilton, Comissão Parlamentar de Inquérito..., p. 52-53.

478 GonÇAlves, Luiz Carlos dos Santos, Poderes de Investigação das Comissões Parlamentares de Inquérito..., p. 132.

${ }^{479}$ COMPARATO, Fabio Konder, Comissões Parlamentares de Inquéritop. 70.

480 GonÇAlves, Luiz Carlos dos Santos, Poderes de Investigação das Comissões Parlamentares de Inquérito..., p. 130-131; CARAJELESCOV, Yuri, Comissões Parlamentares de Inquérito..., p. 116; BADARÓ, Gustavo Henrique Righi Ivahy, Limites aos poderes investigatórios..., BARROSO, Luís Roberto, Comissões Pàrlamentares de Inquérito e suas Competências..., p. 69-70. Este último autor menciona, ainda, dois julgados em que se consolidou o entendimento de que a Comissão Parlamentar de Inquérito deve apurar fatos relacionados com a Administração Pública, haja vista sua instrumentalidade com relação às atribuições do Poder Legislativo. Ver HC 71.039, Rel. Min. Paulo Brossard, DJ de 14.04.94 e MS n. ${ }^{\text {1 }}$ 179/94 TJ/RJ.
} 
Em síntese:

"Podem as CPIs, portanto, investigar fatos sociais de interesse público, mesmo que criminosos, desde que sejam relevantes e de contornos definidos. "481

\subsubsection{PRAZO CERTO}

As Comissões Parlamentares de Inquérito são temporárias por natureza, o que significa que não podem se prolongar indefinidamente. A própria Constituição traz o preceito segundo o qual a CPI deve ser criada por prazo certo, tanto para atender ao princípio da economia processual, quanto para evitar que o investigado seja submetido a um constrangimento desnecessário. Não podem, portanto, transformar-se em órgãos permanentes de investigação. ${ }^{482}$

Exatamente por serem excepcionais e extraordinárias, conforme já anotado acima, suas atribuições exaurem-se assim que o objetivo para o qual foram criadas foi atingido, isto é, a investigação do fato determinado, de maneira que a sua temporariedade é necessária. ${ }^{483}$

A celeridade é cogente para que a investigação atinja sua finalidade e seja efetiva. Outrossim, o direito ao processo razoável é um direito fundamental que foi introduzido em nossa Constituição por meio da EC n. ${ }^{\circ} 45 / 2004$, que inseriu o inciso LXXVIII no artigo $5^{\circ}$, com a seguinte redação: “a todos, no âmbito judicial ou administrativo, são assegurados a

${ }^{481}$ GonçAlves, Luiz Carlos dos Santos, Poderes de Investigação das Comissões Parlamentares de Inquérito..., p. 132.

${ }^{482}$ SiQueIRA JR., Paulo Hamilton, Comissão Parlamentar de Inquérito..., p. 54; GonÇALVES, Luiz Carlos dos Santos Gonçalves, Poderes de Investigação das Comissões Parlamentares de Inquérito..., p. 141; CARAJELESCOV, Yuri, Comissões Parlamentares de Inquérito..., p. 121.

${ }^{483}$ TUCCI, Rogério Lauria, Comissão Parlamentar de Inquérito..., p. 176. 
razoável duração do processo e os meios que garantam a celeridade de sua tramitação", 484

Como o texto constitucional não estabeleceu qual seria o prazo determinado, cabe defini-lo no requerimento de instauração da Comissão. De qualquer maneira, a prorrogação dos trabalhos é admitida se for indispensável para o bom desempenho da tarefa, mas, sendo exceção, só poderá ser concedida pela aprovação da maioria dos membros da Comissão por meio de decisão fundamentada e não deve ultrapassar o fim da legislatura. ${ }^{485}$

Os Regimentos Internos das Casas Legislativas trazem disposições específicas sobre o assunto, que raramente são observadas, haja vista as infindáveis prorrogações. De qualquer maneira, vale anotar que no âmbito da Câmara dos Deputados o prazo máximo estabelecido é de 120 (cento e vinte) dias, com uma prorrogação possível de 60 (sessenta) dias. No que tange ao Senado, a previsão é genérica, determinando-se sua fixação deve ser feita no requerimento e admitindo uma prorrogação sem que se ultrapasse o período de uma legislatura. ${ }^{486}$

\subsubsection{COMPETÊNCIA}

A competência das CPIs é determinada em razão da matéria investigada, a qual deve guardar relação com a competência funcional do órgão legislativo. Assim, são as

\footnotetext{
${ }^{484}$ SIQUEIRA JR., Paulo Hamilton, Comissão Parlamentar de Inquérito..., p. 55.

${ }^{485}$ SiqueIRA JR., Paulo Hamilton, Comissão Parlamentar de Inquérito..., p. 60-61; GonÇALves, Luiz Carlos dos Santos, Poderes de Investigação das Comissões Parlamentares de Inquérito..., p. 141; BADARÓ, Gustavo Henrique Righi Ivahy, Limites aos poderes investigatórios..., p. 11-12; CARAJELESCOV, Yuri, Comissões Parlamentares de Inquérito..., p. 123. Sobre este aspecto, Yuri Carajelescov afirma que a duração dos trabalhos de uma Comissão Parlamentar de Inquérito pode ser de até quatro anos, uma vez que esse é o período máximo da legislatura, mas ressalta que a razoabilidade dita que a conclusão seja alcançada muito antes desse prazo.

${ }^{486}$ CASSEB, Paulo Adib, Controle governamental exercido pelo legislativo..., p. 25.
} 
atribuições constitucionais conferidas a cada um dos órgãos legislativos que limitam o âmbito de atuação das comissões formadas em seu âmbito. ${ }^{487}$

Essa limitação pode ser observada em dois aspectos. O primeiro diz respeito à restrição decorrente da separação de poderes do Estado. Isso significa que não poderão ser investigados atos do Poder Judiciário, uma vez que a atribuição de fiscalização concerne apenas aos atos do Poder Executivo. Da mesma forma, não se pode investigar matéria discutida judicialmente. Por fim, em razão desse limite, as CPIs não podem convocar o Presidente da República como testemunha. ${ }^{488}$

O outro aspecto tem a ver com a distribuição constitucional de competências dentro do Poder Legislativo e entre os níveis federativos, da União, estados-membros e municípios. Ainda, no regime bicameral existente no âmbito da União, a investigação levada a cabo por uma casa legislativa não pode invadir as competências constitucionalmente atribuídas a outra, isto é, Câmara dos Deputados e Senado devem ficar adstritos aos assuntos para os quais são competentes. ${ }^{489}$

\subsubsection{CORRELAÇÃO ENTRE OBJETO E INVESTIGAÇÃO}

A correlação entre o requerimento e o objeto da investigação no âmbito de um inquérito parlamentar é exigida nos mesmos termos em que se exige a correlação entre a acusação e a sentença no Processo Penal. Essa exigência implica que objeto de investigação não se altere durante o procedimento, de modo a garantir a existência plena do contraditório e a efetividade da investigação. ${ }^{490}$

\footnotetext{
${ }^{487}$ SIQUeIRA JR., Paulo Hamilton, Comissão Parlamentar de Inquérito..., p. 66; CoMPARATO, Fabio Konder, Comissões Parlamentares de Inquérito..., p. 70; BADARÓ, Gustavo Henrique Righi Ivahy, Limites aos poderes investigatórios..., p. 11-12.

${ }^{488}$ BADARÓ, Gustavo Henrique Righi Ivahy, Limites aos poderes investigatórios..., p. 11-12; FARIA, Cássio Juvenal e GoMes, Luiz Flávio, Poderes e limites das CPIs, in Boletim IBCCRIM, São Paulo, v. 7, n. ${ }^{\circ}$ 79, jun. 1999, p. 12.

${ }^{489}$ BADARÓ, Gustavo Henrique Righi Ivahy, Limites aos poderes investigatórios..., p. 11-12; FARIA, Cássio Juvenal e GOMES, Luiz Flávio, Poderes e limites das CPIs..., p. 12.

${ }^{490}$ SIQUEIRA JR., Paulo Hamilton, Comissão Parlamentar de Inquérito..., p. 69-71.
} 
Se no decorrer dos trabalhos forem descobertos novos fatos, desde que estejam intimamente ligados ao fato principal, o Supremo Tribunal Federal já se manifestou no sentido de se admitir a inclusão no objeto de investigação. ${ }^{491}$

É o que dissemos no item relativo à determinação do fato. Fato certo e determinado não deve significar fato único, de maneira que é admitida a investigação de outros acontecimentos desde que de interesse público; que haja relação com o núcleo da apuração e que estejam inseridos no âmbito de competência do parlamento em que ela esteja ocorrendo. $^{492}$

\subsection{PARALELISMO COM O PROCESSO PENAL}

A Lei n. ${ }^{\circ} 1.579 / 52$ é expressa ao afirmar que os inquéritos obedecerão, no que lhes for cabível, as normas do Processo Penal. Ainda, os Regimentos Internos das Casas Legislativas podem dispor sobre os poderes das Comissões Parlamentares de Inquérito, conforme preceituado pelo $\S 3^{\circ}$ do artigo 58 da Constituição Federal. Nesse sentido, tanto o Regimento do Senado Federal, quanto o da Câmara de Deputados trazem disposições que autorizam a aplicação subsidiária do Código de Processo Penal. ${ }^{493}$

É sabido que a função exercida pela Comissão Parlamentar de Inquérito, qual seja, a de fiscalização, é totalmente diversa da jurisdicional exercida pelo Poder Judiciário, o qual se socorre das normas previstas no Código de Processo Penal. Embora a apuração realizada não tenha o condão de aplicar a lei ao caso concreto, o resultado dos trabalhos poderá ter como efeito uma certa restrição à liberdade do indivíduo, pois poderá advir da investigação

\footnotetext{
${ }^{491}$ Idem, p. 71. Tal foi a conclusão do HC 71.039, segundo o qual fatos inicialmente imprevistos podem ser aditados aos objetivos da Comissão em ação. STF HC 71.039, Rel. Min. Paulo Brossard, DJ de 14.04.94.

${ }^{492}$ CARAJelescov, Yuri, Comissões Parlamentares de Inquérito..., p. 106 e 114.

${ }^{493}$ GonÇAlves, Luiz Carlos dos Santos, Poderes de Investigação das Comissões Parlamentares de Inquérito..., p. 111; CASSEB, Paulo Adib, Controle governamental exercido pelo legislativo..., p. 25. O artigo 153 do Regimento Interno do Senado afirma: "Nos atos processuais, aplicar-se-ão, subsidiariamente, as disposições do Código de Processo Penal." Já o artigo 36 do Regimento da Câmara é mais amplo: "As Comissões Parlamentares de Inquérito valer-se-ão, subsidiariamente, das normas contidas no Código de Processo Penal."
} 
uma responsabilização perante o Poder Judiciário no caso de remessa das conclusões ao Ministério Público e conseqüente propositura de ação penal. ${ }^{494}$

Dada a natureza do Processo Penal, palco do conflito entre liberdade e segurança:

“...mesmo que os fatos sob investigação não se revistam, sequer em tese, de tipicidade penal, devem ser aplicadas as regras do processo penal por serem as que melhor resguardam a esfera de liberdade das pessoas. Em outros casos, nos quais seja possivel falar potencialmente de crime, o emprego das regras de garantia do processo penal é condição para a própria utilização posterior de provas obtidas, sob pena de sua classificação como ilícitas. "495

Apesar de ser defensor dessa tese, Luiz Carlos dos Santos Gonçalves entende que nem todas as garantias do Processo Penal aplicam-se ao procedimento desenvolvido no âmbito das Comissões Parlamentares de Inquérito, uma vez que têm natureza políticoadministrativa, e não processual. Para ele, as investigações parlamentares são inquisitivas, o que implicaria a dispensabilidade de aplicação do contraditório e da ampla defesa. ${ }^{496}$

O raciocínio estaria correto se concordássemos com a premissa de que o inquérito parlamentar é inquisitivo, mas não é o caso. Conforme já expusemos no item 5.2., adotamos a opinião de Rogerio Lauria Tucci, para quem a investigação parlamentar é um procedimento de natureza administrativa. ${ }^{497}$

Nos termos de Celso Antonio Bandeira de Mello, "Procedimento administrativo ou processo administrativo é uma sucessão itinerária e encadeada de atos administrativos que

\footnotetext{
494 Gonçalves, Luiz Carlos dos Santos, Poderes de Investigação das Comissões Parlamentares de Inquérito..., p. 111-112.

${ }^{495}$ Idem, p. 112.

${ }^{496}$ Idem, p. 115-117.

497 Ao lado do inquérito parlamentar propriamente dito, realizado pelas CPIs, existem, ainda, o inquérito parlamentar administrativo e o parlamentar judicial que podem recomendar aplicações de penas ou medidas disciplinares, o que é vedado no bojo do primeiro. TuCCI, Rogério Lauria, Comissão Parlamentar de Inquérito..., p. 174-175.
} 
tendem, todos, a um resultado final e conclusivo". 498 Se a investigação parlamentar se enquadra nessa definição, não há razão para deixar de aplicar a ela o contido no inciso LV do artigo $5^{\circ}$ da Constituição Federal, segundo o qual a ampla defesa e o contraditório devem ser aplicados aos litigantes do processo administrativo. ${ }^{499}$

Dessa forma, defendemos que todas as garantias do Processo Penal devem ser aplicadas ao inquérito parlamentar na medida em que se fizerem necessárias. O mesmo se diga sobre os dispositivos do Código de Processo Penal, com a ressalva de que esta conclusão não confere aos parlamentares todos os poderes atribuídos às autoridades judiciárias, mas tão somente aqueles referentes à investigação de forma estrita. ${ }^{500}$

Outrossim, esta regra não pode ser utilizada pelos parlamentares apenas quando lhes parecer conveniente. Paulo Adib Casseb alerta para a prática já observada de aplicação daqueles dispositivos do Código de Processo Penal que favorecem seus interesses, utilizando aqueles que enaltecem os poderes da CPI e deixando de aplicar os dispositivos que garantem interesses dos acusados e testemunhas. ${ }^{501}$

\subsection{PODERES INVESTIGATÓRIOS}

Muito se discute sobre a extensão dos poderes investigatórios das CPIs. Mas este não é o tópico no qual discutiremos o significado da letra do texto constitucional, tampouco faremos a conexão com o tema central deste estudo, a reserva de jurisdição. Por ora, basta uma exposição sintética acerca do que temos positivado nesse sentido, já que

\footnotetext{
${ }^{498}$ Mello, Celso Antonio Bandeira de, Curso de Direito Administrativo..., p. 477.

499 Aqui deve ser feita a ressalva com relação aos atos meramente investigatórios. Como trataremos no item 6.1, muitos desses atos dependem do fator surpresa para serem eficientes, caso contrário não lograrão a obtenção de informação necessária. Isso não impede, todavia, que se concretize o contraditório diferido. Cf. SAAD, Marta, O direito de defesa no inquérito policial, São Paulo, Editora Revista dos Tribunais, 2004 , p. 175.

${ }^{500}$ No item 6.2., apresentaremos a diferenciação entre poderes de investigação e poderes de instrução, o que será fundamental para entender o disposto no $\$ 3^{\circ}$ do artigo 58 da $\mathrm{CF}$, bem como para esclarecer que as Comissões Parlamentares de Inquérito não podem invadir o espaço destinado à reserva de jurisdição.

${ }^{501}$ CASSEB, Paulo Adib, Controle governamental exercido pelo legislativo..., p. 23-24. O autor exemplifica com o relato da inobservância do artigo 210 do CPP, o qual assegura às testemunhas o direito de que as demais não tomem ciência do conteúdo de seu depoimento, pela transmissão televisiva do mesmo.
} 
este capítulo é dedicado à análise da estrutura e funcionamento das Comissões Parlamentares de Inquérito.

$\mathrm{O} \S 3^{\circ}$ do artigo 58 da Constituição Federal Brasileira tem a seguinte redação:

$" \S 3^{o}$ - As comissões parlamentares de inquérito, que terão poderes de investigação próprios das autoridades judiciais, além de outros previstos nos regimentos das respectivas Casas, serão criadas pela Câmara dos Deputados e pelo Senado Federal, em conjunto ou separadamente, mediante requerimento de um terço de seus membros, para a apuração de fato determinado e por prazo certo, sendo suas conclusões, se for o caso, encaminhadas ao Ministério Público, para que promova a responsabilidade civil ou criminal dos infratores."

Este parágrafo inserto na Lei Maior traça toda a configuração das Comissões Parlamentares de Inquérito, sobre o que tratamos neste capítulo. Contudo, os estudos sobre o tema dão especial destaque para a expressão "poderes de investigação próprios das autoridades judiciais”, que dá os contornos acerca de como as comissões poderão atuar.

É sabido, todavia, que a expressão é demasiadamente ampla, de maneira que é indispensável realizar um esforço interpretativo para definir seu exato alcance. ${ }^{502}$

Além disso, outras sedes formais dispõem sobre os poderes de investigação: o Regimento Interno das Casas Congressuais, a própria lei processual atinente aos poderes dos juízes, no que estiver consoante com a ordem constitucional, conforme já explicado no item 5.4, e a Lei n. ${ }^{\mathrm{o}} 1.579 / 52 .{ }^{503}$

\footnotetext{
${ }^{502}$ Trata-se de um conceito jurídico indeterminado, uma vez que a lei não define "poderes de investigação próprios das autoridades judiciais". De acordo com a definição dada no Dicionário jurídico elaborado Por Maria Helena Diniz, conceito indeterminado é: "Aquele cujo conteúdo e extensão são incertos". Ver DINIZ, Maria Helena, Dicionário jurídico, V. 1, São Paulo, Editora Saraiva, 1998, p. 721

503 Gonçalves, Luiz Carlos dos Santos, Poderes de Investigação das Comissões Parlamentares de Inquérito..., p. 45.
} 
Sobre a Lei das Comissões Parlamentares de Inquérito, n. ${ }^{\circ}$ 1.579/52, já expusemos o entendimento de Luiz Carlos dos Santos Gonçalves de que não foi recepcionada pela Constituição de 1988 no que concerne aos poderes conferidos às CPIs, uma vez que o tema foi tratado pelo Constituinte. ${ }^{504}$

Para outros autores, todavia, como Rogério Lauria Tucci, Cleunice Pitombo, Luis Roberto Barroso, Cassio Juvenal Faria, a Lei n. ${ }^{\circ} 1.579 / 52$ permanece em vigor e, sobretudo em seu artigo $2^{\circ}$, disciplina todos os poderes das Comissões Parlamentares de Inquérito. ${ }^{505}$ Estamos com estes autores, entendendo que os poderes conferidos às CPIs são aqueles delineados neste texto legal, o qual revela uma postura consoante com a teoria da reserva de jurisdição, como explicaremos no capítulo a seguir.

Ainda sobre a normatização do tema, no que tange aos Regimentos das Casas Legislativas, a prescrição constitucional é que tratarão de outros poderes de investigação além daqueles próprios das autoridades judiciais. A redação do texto constitucional não deixa dúvidas de que esses outros poderes só podem ser de investigação também, já que o escopo das Comissões Parlamentares de Inquérito é unicamente investigar. ${ }^{506}$

A idéia é que os Regimentos adaptem as previsões relativas aos poderes de investigação judiciais à realidade do procedimento político administrativo levado a cabo no âmbito de uma CPI, devendo limitar-se, portanto, a dispor sobre meios de investigação e provas. $^{507}$ Nesse sentido é a observação de Yuri Carajelescov, segundo o qual esses poderes são excepcionais e têm caráter instrumental com relação ao objeto das investigações parlamentares, de sorte que só podem visar à obtenção de elementos probatórios no que tange ao objeto da investigação daquela CPI. É a necessidade de relação entre os meios e os fins adotados pelo órgão. ${ }^{508}$

\footnotetext{
504 GonÇAlves, Luiz Carlos dos Santos, Poderes de Investigação das Comissões Parlamentares de Inquérito..., p. 47-49; 143.

${ }^{505}$ TuCCI, Rogério Lauria, Comissão Parlamentar de Inquérito..., p. 174-175; BARroso, Luis Roberto, Comissões Parlamentares de Inquérito..., p.807; PIтомBO, Cleunice A. Valentim Bastos, Comissão Parlamentar de Inquérito..., p. 270.

506 Gonçalves, Luiz Carlos dos Santos, Poderes de Investigação das Comissões Parlamentares de Inquérito..., p. 50.

507 Gonçalves, Luiz Carlos dos Santos, Poderes de Investigação das Comissões Parlamentares de Inquérito..., p. 50-51.

${ }^{508}$ CARAJelescov, Yuri, Comissões Parlamentares de Inquérito..., p. 133.
} 
Por ora, as considerações aqui empreendidas são suficientes, uma vez que o capítulo a seguir versará sobre os poderes da Comissões Parlamentares de Inquérito de forma aprofundada.

\subsection{LIMITES DA ATUAÇÃO}

Yuri Carajelescov explica que o fundamento de validade das Comissões Parlamentares de Inquérito é extraído das constituições, as quais balizam suas atividades, impondo alguns limites de atuação. O autor divide-os em formais e materiais. Estes são princípios genéricos balizadores da ordem constitucional, tais como o princípio da separação dos poderes e o respeito aos direitos e garantias fundamentais. Aqueles são os requisitos específicos impostos pelo texto maior para que seja instalada uma CPI. ${ }^{509}$

Sendo assim, os limites formais nada mais são do que os requisitos já analisados no item 5.3, notadamente, impossibilidade de investigar fato indeterminado ou exclusivamente privado; proibição de instaurar inquérito parlamentar sem que se atinja o quorum mínimo no requerimento; proibição de ultrapassar o prazo máximo fixado para o término dos trabalhos; e impossibilidade de ultrapassar a competência do Poder Legislativo em questão. ${ }^{510}$

No que tange aos limites materiais, que são princípios genéricos que também podem ser aplicados às CPIs, embora as normas relativas à questão a eles não façam referência expressa, esclarecedora é a seguinte passagem: "Por se imporem a toda e qualquer ação estatal, colhem e fixam as balizas da ação de investigação parlamentar." Explica o autor que, por sua natureza, autores como Jorge de Miranda o classificam como limites extrínsecos à investigação parlamentar. ${ }^{511}$

\footnotetext{
${ }^{509}$ CARAJelescov, Yuri, Comissões Parlamentares de Inquérito..., p. 165.

${ }^{510}$ Idem, p. 167.

${ }^{511}$ Idem,, p. 169.
} 
O princípio da separação dos poderes, abordado com minúcia nos itens $2.4 .3 \mathrm{e}$ 2.5.1, é central no concernente às Comissões Parlamentares de Inquérito. Isso porque sua existência é um corolário direto do mecanismo de "checks and balances" essencial ao controle recíproco que deve existir entre as funções estatais ao exercer a função de fiscalização. Mas a relação entre o princípio e as CPIs não é apenas relativa à sua origem. $^{512}$

Com efeito, a divisão de tarefas entre os órgãos que exercem as diversas funções estatais é também limitadora da atuação das Comissões Parlamentares de Inquérito, na medida em que as impede de se imiscuir no núcleo das atividades atribuídas aos demais Poderes do Estado. Este ponto é fundamental para o tema deste estudo, a reserva de jurisdição, conforme já abordado no Capítulo 3.

Individualizando as inúmeras possibilidades de interferência no desenvolvimento de atividades dos diferentes poderes para a situação em que as Comissões Parlamentares de Inquérito acabam por executar algumas tarefas ínsitas à atividade jurisdicional, é imperioso anotar que existe um limite para esta interpenetração.

Uma das características essenciais ao Poder Judicial é sua independência com relação aos demais poderes. Com efeito, Canotilho qualifica essa independência dos tribunais, referindo-se aos sentidos positivo e negativo. Este último significa a proibição da atuação de outros órgãos nas atividades estritamente jurisdicionais, enquanto que o primeiro revela a existência de atos que são exclusivos do Poder Judiciário. ${ }^{513}$

Ora, sendo a Comissão Parlamentar de Inquérito procedimento levado a cabo pelo Poder Legislativo, não pode se furtar à observância deste corolário do princípio da separação dos poderes, sendo impedida de exercer qualquer ato que pertença ao núcleo essencial da função jurisdicional, isto é, que esteja acobertado pela reserva de jurisdição absoluta. $^{514}$

\footnotetext{
${ }^{512}$ Carajelescov, Yuri, Comissões Parlamentares de Inquérito..., p. 170.

${ }^{513}$ CANOTILHO, José Joaquim Gomes, Direito constitucional e teoria da constituição..., p. 660 e 664.

514 Já vimos que ato exclusivamente jurisdicional é aquele que tem por escopo a resolução de conflitos de interesses constitucionalmente protegidos maneira definitiva. Ver itens 3.1.2 e 3.3.
} 
Essa tese será melhor desenvolvida no capítulo 6 a seguir, mas ficou clara, por ora, a existência deste limite material que se impõe à investigação parlamentar.

Cumpre, ainda, tecer algumas considerações sobre a limitação imposta pelos direitos fundamentais. Neste ponto, não há segredo. Toda a atuação estatal deve ter em vista que os direitos e garantias fundamentais são um dos pilares do Estado Democrático de Direito. Sendo a investigação parlamentar uma das expressões da atuação estatal, não escapa a essa imposição, sendo imperioso que seus trabalhos sejam pautados pelo respeito a estes preceitos, sob pena de contrariarem pilar fundamental do Estado Brasileiro.

Nesse sentido, a passagem:

"De fato, o poder de investigação das comissões parlamentares de inquérito encontra um limite material constitucional nesses direitos, liberdades e garantias constitucionalmente consagrados, na medida em que todas as atividades estatais se submetem aos seus primados, inclusive as de natureza política desempenhadas, por exemplo, no âmbito do Parlamento." 515

\subsection{POSSÍVEIS RESULTADOS}

Concluídos os trabalhos da Comissão, com respeito a todos os limites a ela impostos, há que se elaborar um relatório para deixar consignado tudo o que foi colhido e observado na investigação. Por óbvio, este relatório não possui natureza jurídica de sentença, nem é uma decisão administrativa em sentido estrito. Não possui sequer conotação de deliberação, tratando-se de impressões decorrentes das investigações

${ }^{515}$ CARAJElescov, Yuri, Comissões Parlamentares de Inquérito..., p. 174. 
perpetradas que servirão de fundamento às decisões nos demais âmbitos, sempre com vistas a dar cumprimento ao ordenamento jurídico, tendo natureza política. ${ }^{516}$

Paulo Hamilton Siqueira Jr. afirma que:

"Por intermédio desse relatório final, a Comissão Parlamentar de Inquérito cumpre sua finalidade de vigiar o cumprimento da Constituição e das leis e apreciar os atos de governo e da administração. No primeiro aspecto, verifica-se a preservação do Estado de Direito, e a segunda finalidade indica o aprimoramento da democracia. ${ }^{, 517}$

No caso de ter sido constatada a existência de indícios de responsabilidade civil ou criminal, essas conclusões devem ser encaminhadas ao Ministério Público, de acordo com o texto Constitucional. Também é interessante o envio à Mesa da Casa Legislativa e ao Tribunal de Contas da União, porquanto este é o órgão que auxilia o Parlamento a desempenhar sua função de controle das contas públicas. Outrossim, as conclusões podem ser remetidas ao próprio Poder Executivo para que possa adotar medidas pertinentes. Ressalte-se que o ideal é que uma comissão legislativa permanente relacionada à matéria em questão acompanhe as providências tomadas a posteriori. ${ }^{518}$

José Alfredo de Oliveira Baracho alerta, ainda, para a possibilidade da CPI concluir pela elaboração de um projeto de resolução, no caso do tema ser de competência do Senado. De acordo com o Regimento Interno da Câmara dos Deputados, que é mais detalhado do que o do Congresso, também é possível remeter os documentos resultantes à

\footnotetext{
${ }^{516}$ CARAJElescov, Yuri, Comissões Parlamentares de Inquérito..., p. 162; TUCCI, Rogério Lauria, Comissão Parlamentar de Inquérito..., p. 178.

${ }_{517}$ SIQUeIRA JR., Paulo Hamilton, Comissão Parlamentar de Inquérito..., p. 141.

518 SiQueIRA JR., Paulo Hamilton, Comissão Parlamentar de Inquérito..., p. 139; CARAJELESCOV, Yuri, Comissões Parlamentares de Inquérito..., p. 163.
} 
Advocacia-Geral da União para que promova ações com o escopo de realizar a responsabilidade civil ou criminal. ${ }^{519}$

Aqui há uma interessante observação feita por Yuri Carajelescov. Dissemos acima que as CPIs são um importante instrumento da minoria parlamentar. Pois bem. Não se pode admitir, por outro lado, que este mecanismo seja utilizado de forma desvirtuada, ensejando perseguições políticas por parte da minoria em face da maioria. Sendo assim, buscando o equilíbrio, é a maioria parlamentar que tem a palavra final acerca das conclusões, devendo aprová-las. ${ }^{520}$

${ }^{519}$ BARACHO, José Alfredo de Oliveira, As Comissões Parlamentares na Constituição de 1988..., p. 66-67. ${ }^{520}$ CARAJElEsCov, Yuri, Comissões Parlamentares de Inquérito..., p. 93. 


\section{REFLEXOS DA RESERVA DE JURISDIÇÃO NO INQUÉRITO PARLAMENTAR}

O último capítulo desta dissertação tem como escopo a análise dos poderes investigatórios das Comissões Parlamentares de Inquérito, estabelecendo em que medida elas se aproximam dos poderes conferidos aos membros da magistratura e em que medida elas se afastam, de modo a delinear os contornos da aplicação da cláusula de reserva de jurisdição no âmbito do inquérito parlamentar.

O objetivo é interpretar o $\S 3^{\circ}$ do artigo 58 da Constituição Federal Brasileira da forma mais consentânea com os princípios da separação de poderes, Estado Democrático de Direito e direitos fundamentais.

No Capítulo 4 tratamos do conceito de instrução processual e analisamos algumas medidas restritivas de direitos fundamentais que são efetivadas ou no bojo de um Processo Penal, ou em uma investigação preliminar com o escopo de embasá-lo. A situação muda um pouco de figura quando tais medidas tornam-se necessárias para aclarar fatos no âmbito de uma investigação desenvolvida por parlamentares sem que, necessariamente, se tenha o objetivo de fundamentar uma ação judicial.

Não estaremos mais diante de uma instrução processual em sentido estrito, tampouco haverá o objetivo central de comprovar a autoria e materialidade de um crime. Os conceitos sofrem alterações e pretendemos analisar como tal fato afetará a forma pela qual a investigação deve ocorrer ou, ao menos, em que medida a analogia com o inquérito policial, por exemplo, deve ser aplicada.

Com efeito, a investigação feita por parlamentares é realidade que se impõe. Ela não só existe, como ocorre reiteradamente no âmbito de todos os entes federativos brasileiros: União, estados-membros e municípios. Considerando a inafastabilidade das investigações levadas a cabo pelas Comissões Parlamentares de Inquérito, resta estabelecer a maneira pela qual devem desenvolver-se sem afrontar os ditames do Estado Democrático de Direito. 
Para tanto, passamos a analisar seus elementos e características, identificando os pontos em que o inquérito parlamentar se aproxima da uma investigação desenvolvida com a finalidade de instruir uma ação judicial e aqueles em que se afasta.

\subsection{A INVESTIGAÇÃO REALIZADA NO ÂMBITO DO INQUÉRITO PARLAMENTAR}

A finalidade das Comissões Parlamentares de Inquérito já foi tratada no item 5.2.. Todavia, um exame mais aprofundado sobre a real natureza do inquérito parlamentar será essencial para auxiliar no objetivo de definir o exato alcance dos poderes conferidos àqueles que a empreendem.

Dissemos, com base em definição de Luiz Carlos dos Santos Gonçalves, que o escopo das Comissões Parlamentares de Inquérito é apurar o fato certo e determinado para o qual foram constituídas de forma relacionada ao papel político do Congresso Nacional. Sua natureza jurídica é, portanto, de procedimento político-administrativo. ${ }^{521}$

Nesse sentido, Rogerio Lauria Tucci esclarece que a investigação levada a cabo no âmbito das CPIs tem natureza de inquérito parlamentar em sentido estrito ${ }^{522}$, quer dizer, sua natureza é administrativa e sua finalidade é investigatória, para obter dados e informações sobre os fatos investigados, os quais se relacionam com irregularidades no Poder Executivo. ${ }^{523}$ É um mecanismo dos freios e contrapesos atinentes ao Estado de Direito.

\footnotetext{
521 Gonçalves, Luiz Carlos dos Santos, Poderes de Investigação das Comissões Parlamentares de Inquérito..., p. 41.

${ }^{522}$ Segundo Danielle Souza de Andrade e Silva, três são as espécies de inquérito parlamentar: o administrativo, destinado a apurar a responsabilidade dos funcionários do Poder Legislativo; o judicial, cujo resultado é o impeachment de governante; e o parlamentar propriamente dito, que é realizado pelas Comissões Parlamentares de Inquérito para controlar o Executivo. Ver SILVA, Danielle Souza de Andrade e, A investigação preliminar nos delitos de competência originária de tribunais, Tese de Doutorado apresentada na Faculdade de Direito da Universidade de São Paulo, 2009, p. 108.

${ }_{523}$ Ao lado do inquérito parlamentar propriamente dito, realizado pelas CPIs, existem, ainda, o inquérito parlamentar administrativo e o parlamentar judicial que podem recomendar aplicações de penas ou medidas disciplinares, o que é vedado no bojo do primeiro. TUCCI, Rogério Lauria, Comissão Parlamentar de Inquérito..., p. 174-175.
} 
Fica claro, assim, que as CPIs não têm como objetivo central lastrear a propositura de ações, embora tal providência possa advir de suas atividades como resultado secundário. Da mesma forma, o estudo para alterações legislativas não é seu escopo principal, mas pode ser uma consequiência. ${ }^{524}$

Posto isto, cumpre passar ao exame das investigações preliminares ${ }^{525}$ para que, após, seja possível definir a relação entre estas e as CPIs.

\subsubsection{INVESTIGAÇÕES PRELIMINARES}

Investigações preliminares são todas aquelas levadas a cabo em momento préprocessual, mas sempre com vistas a averiguar a ocorrência e autoria de crimes, buscando dados elucidativos do fato supostamente típico, isto é, visando à formação de culpa. $\mathrm{Na}$ maior parte das vezes, essa apuração prévia fica a cargo das autoridades policiais, nos termos do artigo 144 da Constituição Federal e do artigo $4^{\circ}$ do Código de Processo Penal. Todavia, também podem ser presididas por autoridades administrativas, parlamentares, e até particulares. ${ }^{526}$

\footnotetext{
${ }^{524}$ SIQUEIRA JR., Paulo Hamilton, Comissão Parlamentar de Inquérito..., p. 9; GONÇALVES, Luiz Carlos dos Santos, Poderes de Investigação das Comissões Parlamentares de Inquérito..., p. 40 e 58.

${ }^{525}$ Utilizamos a expressão consolidada na doutrina de investigação preliminar, todavia, ressaltamos sua impropriedade. Primeiro porque, conforme será exposto, as espécies de investigação preliminar não abarcam apenas atos de investigação, mas também de instrução. E depois porque é incoerente falar em investigação preliminar quando não existe uma definitiva. Nesse sentido, Aury Lopes Jr. sugere a utilização da expressão "instrução preliminar". Já Sergio Marcos de Moraes Pitombo fala em persecução penal preliminar ou prévia, Cf. LOPES JR., Aury, Sistemas de Investigação Preliminar no Processo Penal, $4^{\mathrm{a}}$ Ed. rev, ampl.e atual., Rio de Janeiro, Editora Lumen Juris, 2006, p. 38; e Pгтомво, Sérgio Marcos de Moraes, Inquérito policial: exercício do direito de defesa, in Boletim IBCCrim, n..$^{\circ}$ 83, esp., Out., 1999.

${ }^{526}$ OliverRa, Eugêncio Pacelli de, Curso de Processo Penal, $11^{a}$ Ed., Rio de Janeiro, Editora Lumen Juris, 2009, p. 43 e 86; SiLva, Danielle Souza de Andrade e, A investigação preliminar..., p. 81-85; Sobre a constatação do instituto nos três Poderes do Estado: "No sistema brasileiro, a persecução penal preliminar ou prévia emerge nas três faces do Poder Executivo, Legislativo e Judiciário. Perante a administração divisam-se o inquérito policial civil e o militar; mais o procedimento administrativo, em sentido estrito. No Legislativo, pode irromper inquérito parlamentar, cujo resultado, de modo eventual, importe ao processo penal. No Judiciário, acham-se o inquérito judicial, da Lei de Falência e, ainda, a formação judicial do corpo de delito e contingente apontamento da autoria, nos crimes contra a propriedade imaterial." Ver PIтомво, Sérgio Marcos de Moraes, Inquérito policial...,. Seguindo o autor, SAAD, Marta, $O$ direito de defesa no inquérito policial..., p. 99.
} 
Eugenio Pacelli de Oliveira conceitua o instituto da investigação:

"A fase de investigação, portanto, em regra promovida pela polícia judiciária, tem natureza administrativa, sendo realizada anteriormente à provocação da jurisdição penal. Exatamente por isso se fala em fase pré-processual, tratando-se de procedimento tendente ao cabal e completo esclarecimento do caso penal, destinado, pois, à formação do convencimento (opinio delicti) do responsável pela acusação. ",527

Embora a coleta de elementos probatórios mínimos seja o foco da atividade levada a cabo no bojo de uma investigação preliminar, há que se destacar seu caráter preservador. Explica-se. Ao exigir uma fundamentação mínima para a acusação, a qual, na maior parte das vezes, depende da apuração prévia para ser alcançada, o ordenamento jurídico veda acusações infundadas e abusos na persecução, salvaguardando a sociedade do cometimento de injustiças. Ademais, a função que exerce de conservar os vestígios relativos aos fatos investigados, tem caráter acautelatório e prepara a futura acusação. Diante disso, Marta Saad fala em função preservadora e função preparatória da persecução inicial. ${ }^{528}$

Por fim, merecem menção as duas características que Aury Lopes Jr. atribui à investigação preliminar de cunho penal: autonomia e instrumentalidade. A primeira manifestar-se-ia nos casos em que o processo não sucede a investigação, quando esta é arquivada antes da deflagração da ação. Já a segunda, decorre do fato de servir de instrumento para encontrar e introduzir no processo elementos necessários ao exercício da pretensão punitiva, dado seu caráter preparatório. ${ }^{529}$

Cotejando esses conceitos com a finalidade das Comissões Parlamentares de Inquérito, chegamos à conclusão de que há vezes em que estas são constituídas unicamente

${ }^{527}$ OliveIRA, Eugêncio Pacelli de, Curso de Processo Penal..., p. 43

${ }^{528} \mathrm{SAAD}$, Marta, O direito de defesa no inquérito policial..., p. 23-24; SILVA, Danielle Souza de Andrade e, A investigação preliminar..., p. 81.

${ }^{529}$ LOPES JR., Aury, Sistemas de Investigação Preliminar..., p. 46-47. Também SILVA, Danielle Souza de Andrade e, A investigação preliminar..., p. 82-84. 
para averiguar fatos irregulares no âmbito da administração pública e não acarretam outras conseqüências, ou o único resultado concreto delas advindo é a elaboração de um novo texto legislativo. Nesses casos, diremos que a investigação perpetrada pelas CPIs é autônoma. Outras situações, porém, nas quais são encontrados indícios de autoria e materialidade de um fato típico, ensejam o encaminhamento das conclusões parlamentares ao Ministério Público e, nestes casos, o inquérito parlamentar será, também, uma investigação preliminar, de caráter instrumental e preparatório. ${ }^{530}$

Oportuna a transcrição do trecho a seguir:

"Os fins das investigações parlamentares não podem afastar-se dos fins do Poder Legislativo. Mas seu caráter eminentemente parlamentar, destinado à sindicância de atos do governo, não obsta venha servir, eventual e secundariamente, para subsidiar a persecução criminal, na medida em que as conclusões da investigação são encaminhadas ao Ministério Público, que poderá, com base nelas, promover, de logo, a ação penal. Funciona, assim, como mais uma forma de investigação preliminar que pode ter reflexos na seara penal. ",531

A identificação do inquérito parlamentar em sentido estrito com uma investigação preliminar permite a extração de algumas conclusões. A primeira delas e mais importante é que, ao ser caracterizada como investigação pré-processual, aproxima-se do inquérito policial, fato que acarretará o mesmo tratamento a ambas em diversos momentos,

\footnotetext{
530 De acordo com o Dicionário Houaiss, preliminar é aquilo "que antecede (o principal)", enquanto autônomo pode ser aquilo "que é um conjunto perfeito, e não uma parte no desenvolvimento seqüencial de um organismo". Diante desses conceitos, parece contraditório classificar um instituto como preliminar e autônomo ao mesmo tempo, pois algo que não faz parte de uma seqüência de atos não pode anteceder qualquer coisa. A forma mais coerente de se conciliar todos os conceitos é afirmar que a investigação parlamentar é autônoma, pois não tem como objetivo instruir uma acusação penal, salvo quando serve de instrumento preparatório para uma ação judicial, quando será caracterizada como espécie de investigação preliminar. Dicionário Houaiss eletrônico. Disponível em http://houaiss.uol.com.br. Acesso em 18.02.2010. Nesse sentido, Marta Saad afirma: “Assim, apenas de modo eventual o inquérito parlamentar pode funcionar como persecução penal preparatória ou prévia." SAAD, Marta, O direito de defesa no inquérito policial..., p. 118 ;

${ }^{531}$ SILVA, Danielle Souza de Andrade e, A investigação preliminar..., p. 109.
} 
sobretudo no que diz respeito aos limites de suas atuações. ${ }^{532}$ A segunda é que, por se tratar de investigação preliminar, os atos praticados em seu bojo, em regra, não poderão ser considerados como prova em seu sentido mais estrito.

É sabido que, de uma forma genérica, prova é a forma pela qual os fatos são demonstrados. ${ }^{533}$ Todavia, no âmbito processual, algumas peculiaridades são acrescidas a sua definição para que possua validade: a presença do juiz e das partes. Com efeito, só será considerada prova judicial aquela que for produzida em contraditório e perante o juiz natural, para que se possa formar o convencimento deste acerca da ocorrência ou não de determinados fatos. ${ }^{534}$ Inclusive, este foi o entendimento abarcado pelo legislador quando alterou o texto do caput do artigo 155 do Código de Processo Penal para fazer constar que a convicção do juiz depende de prova produzida em contraditório judicial. ${ }^{535}$

Sendo assim, genericamente, os atos praticados em qualquer investigação preliminar não podem ser considerados como provas nem podem ter o condão de formar o convencimento de um juiz num futuro processo. Ora, se o ato produzido desta forma não pode ser considerado prova justamente porque não é produzido perante um membro do Poder Judiciário, parece bastante incoerente pensar que atos exclusivamente jurisdicionais possam ser praticados pelas autoridades que presidem esse tipo de investigação. Não há consonância com o modelo de justeza funcional preconizado por Canotilho.

E essa conclusão será imperiosa, qualquer que seja a modalidade de inquérito parlamentar, autônoma ou preliminar, da persecução penal. A prova produzida no decorrer dos trabalhos de um inquérito parlamentar em sentido estrito será apenas uma forma de

\footnotetext{
532 Cleunice Pitombo afirmou que "A faculdade investigatória, atribuída às comissões parlamentares de inquérito, assemelha-se àquelas conferidas ao delegado de polícia, no exercício da persecução penal extrajudicial, ou persecução penal prévia." Рітомво, Cleunice A. Valentim Bastos, Comissão Parlamentar de Inquérito..., p. 275. No mesmo sentido, LACAVA, Thaís Aroca Datcho, Sigilo na CPI e as garantias individuais, in FERnANDES, Antonio Scarance, ALMEIDA, José Raul Gavião de, e MorAES, Maurício Zanoide de, Sigilo no processo penal: eficiência e garantismo, São Paulo, Editora Revista dos Tribunais, 2008, p. 127.

533 Segundo o Dicionário Houaiss, prova é evidência; demonstração. Dicionário Houaiss eletrônico. Disponível em http://houaiss.uol.com.br. Acesso em 18.02.2010.

534 Grinover, Ada Pellegrini, Fernandes, Antonio Scarance, Gomes FILHO, Antonio Magalhães, As nulidades no processo penal..., p. 143 e 146.

${ }^{535}$ A nova redação foi dada pela Lei n. ${ }^{\circ} 11.690 / 2008$, um dos instrumentos normativos que levaram a cabo significativa reforma no processo penal brasileiro, in verbis: “Art. 155. O juiz formará sua convicção pela livre apreciação da prova produzida em contraditório judicial, não podendo fundamentar sua decisão exclusivamente nos elementos informativos colhidos na investigação, ressalvadas as provas cautelares, não repetiveis e antecipadas".
} 
demonstrar fatos, de aclarar pontos de controvérsias, mas não poderá ser utilizada com o escopo de promover uma condenação judicial, seja ela cível ou penal. De qualquer maneira, é interessante analisarmos a natureza dos atos produzidos em seu interior, com o desígnio de esclarecer, adiante, a real acepção da expressão "poderes de investigação próprios das autoridades judiciais."

\subsubsection{A NATUREZA DOS ATOS PRATICADOS NA INVESTIGAÇÃO PRELIMINAR}

Embora a investigação preliminar não possua natureza de instrução definitiva, seus atos não são exclusivamente investigatórios. Sua natureza varia conforme sejam materializados ou não, permitam ou não a participação do investigado na sua realização e possam ou não ser valorados pelo juiz no momento final de sua utilização, classificando-se em: atos de investigação; atos de instrução e atos de prova. ${ }^{536}$

Danielle Souza de Andrade e Silva, em Tese de Doutorado dedicada ao estudo da investigação preliminar, efetuou a análise dessa tripartição dos atos e adotaremos aqui suas definições, em muito baseadas nas conclusões de Marta Saad em obra sobre o Inquérito Policial. ${ }^{537}$ Num primeiro momento, a autora define e distingue as categorias da investigação e da instrução em parágrafo cuja reprodução se impõe para o melhor entendimento da questão:

\footnotetext{
${ }^{536}$ SILVA, Danielle Souza de Andrade e, A investigação preliminar..., p. 163. Essa é a classificação que resolvemos adotar no nosso estudo, porquanto a ele melhor se adéqua, todavia, não é unânime. Há que se destacar que Aury Lopes Jr. divide os atos com finalidade probatória apenas em atos de investigação e atos de prova, e o critério distintivo é a, basicamente, possibilidade de servir de base para a sentença ou não. Desse modo, entende que atos de investigação formam um juízo de probabilidade, destinam-se à formação da opinio delicti, servem de fundamento para decisões interlocutórias e medidas cautelares, podendo ser praticados pelo Ministério Público e pela polícia. Já os atos de prova destinam-se a convencer o juiz sobre uma afirmação, integram o processo e servem à fundamentação da sentença. Além disso, devem respeitar os princípios da imediação, contradição, publicidade e sua prática deve ser perante o magistrado. Cf. LOPES JR., Aury, Sistemas de Investigação Preliminar..., p. 137-138.

${ }^{537}$ SILVA, Danielle Souza de Andrade e, A investigação preliminar...; SAAD, Marta, $O$ direito de defesa no inquérito policial...
} 
"Investigação deriva do latim investigatio, do verbo investigare, que significa indagar com cuidado, seguir o rastro, perscrutar. É a operação de perquirir, rastrear, pesquisar, seguindo vestígios, informações necessárias à elucidação do fato. Instrução, a sua vez, vem do latim instructio, que quer dizer transmissão de conhecimentos. Consiste na atividade que visa a produzir prova do fato incriminado, para deles dar conhecimento ao Poder Judiciário. Instruir é materializar o que se investigou, para dá-lo a conhecer a alguém. Assim é que, tãologo a autoridade condutora da investigação obtenha informações ou meios de prova, tratará de reduzir a escrito o resultado de suas pesquisas, com a finalidade documentá-los (sic) em um instrumento (v.g., o inquérito policial) que servirá a instruir o convencimento do titular da ação penal e da autoridade judicial. Passase, então, da investigação à instrução, surgindo o inquérito como o corpo da investigação, o 'instrumento organizatório das investigações realizadas'., „538

Extrai-se daí que os atos de investigação propriamente ditos são todos aqueles que procuram informações para esclarecer determinada ocorrência, sendo que, no âmbito do inquérito policial, são aqueles que, após a notícia da infração penal, preservam o local do crime, sondam testemunhas, procuram vestígios do delito e de sua autoria. ${ }^{539}$ Nos termos de Marta Saad:

"A investigação criminal é a pesquisa sistemática e seqüente do objeto, utilizando os meios de apoios técnicos disponíveis, e desenvolve-se pela informação, por meio de fontes regulares ou estimuladas, pela indagação técnica e pela posterior instrumentação, dependente dos recursos técnicos disponíveis. "540

\footnotetext{
${ }^{538}$ SILVA, Danielle Souza de Andrade e, A investigação preliminar..., p. 163-164.

${ }^{539}$ Idem.

${ }^{540}$ SAAD, Marta, O direito de defesa no inquérito policial..., p. 166.
} 
Por outro lado, os atos de instrução relacionam-se com a concretização daquilo que foi investigado, tendo em vista a transmissão de conhecimento a alguém. Na prática, são a redução a termo das diligências efetuadas. Sua função primordial é aparelhar o magistrado de conhecimentos que o possibilitem o melhor julgamento, servindo também para fundamentar a decisão do titular da ação penal. ${ }^{541}$

Aqui, cumpre acrescentar outro elemento diferenciador, destacado por Marcos Alexandre Coelho Zilli, que entendemos ser compatível com a classificação adotada pelas autoras estudadas. Esclarece o autor que a atividade instrutória visa verificar a veracidade de um enunciado, ou seja, toma por base uma hipótese de acusação já elaborada. Ao contrário, a atividade investigativa é a pesquisa de um fato aparentemente ilícito que pode ou não resultar na formalização de uma acusação, levando a uma proposição simples. ${ }^{542}$

Essa conclusão foi baseada em raciocínio de Sergio Marcos de Moraes Pitombo, ${ }^{543}$ no qual Marta Saad também se inspirou ${ }^{544}$, donde concluímos que as descrições não são excludentes. Observe-se que a referida hipótese de acusação não é, necessariamente, a denúncia. Pode ser a linha de investigação que se mostrou mais plausível e foi adotada pela autoridade policial e pelo acusador.

Destarte, razoável afirmar que os atos de instrução são a materialização dos resultados das diligências e ocorrem após a definição de uma linha de acusação, da formulação de uma proposição. Servem para aparelhar o titular da ação penal de subsídios

\footnotetext{
${ }^{541}$ SILVA, Danielle Souza de Andrade e, A investigação preliminar..., p. 164; SAAD, Marta, $O$ direito de defesa no inquérito policial..., p. 167-168.

${ }^{542}$ ZILLI, Marcos Alexandre Coelho, A iniciativa instrutória..., p. 211. É por entender dessa forma que o autor preconiza a idéia de que ao juiz é admitida a iniciativa instrutória, mas não a atividade investigatória. Preleciona, ainda, que instrução não é uma fase da persecução, mas sim a iniciativa em direção ao acertamento fático. Op. cit., nota 56, p. 118.

543 "A investigação consiste no indagar de modo metódico e continuado, a respeito de certa noticiada ocorrência. Quem investiga só rastreia o fato - que lhe pareceu ilícito e típico - suas circunstâncias, bem como possível autoria. A investigação ou averiguação pode levar a uma preposição simples, cabendo à instrução concluir se verdadeiro ou falso o mero enunciado. Em regra e por isso, a investigação antecede à instrução preliminar. Já, em ambas as fases da persecução penal, a instrução mostra-se como atividadeque a proposição, simples ou qualificada, provocou - dirigida e tendente a colher ou produzir prova, sobre a existência de fato, que se desenha ilícito e típico; e, ainda, lhe indicar o agente, ou agentes. Na fase preliminar, prévia, ou preparatória da ação penal, de índole condenatória, a polícia judiciária pratica atos de investigação e outros de instrução criminal, suscetíveis de se repetirem, em juízo, ou não." Cf. PITOMBO, Sergio Marcos de Moraes, Breves notas sobre o anteprojeto de lei, que objetiva modificar o Código de Processo Penal, no atinente à investigação policial, in ScHECAIRA, Sérgio Salomão (org.), Estudos Criminais em Homenagem a Ecandro Lins e Silva, São Paulo, Editora Método, 2001, p. 344.

${ }^{544} \mathrm{SAAD}, \mathrm{Marta}, \mathrm{O}$ direito de defesa no inquérito policial..., p. 170.
} 
para a hipótese acusatória que emerge no curso das investigações, para instruir o juiz no que tange à decisão do recebimento ou não da denúncia e para fundamentar a sentença. Contudo, neste último caso, dever-se-á acrescentar uma nova qualidade, a definitividade, que transformará o ato de instrução em ato de prova e possibilitará sua utilização para a fundamentação da sentença.

Isso porque, o que diferencia os atos de prova dos atos de instrução é a definitividade, a qual, em geral, só existe nos atos produzidos em contraditório e perante o juiz natural. Explica-se. Os atos de instrução podem ser transitórios, esgotando-se no procedimento preliminar, ou perenes, cuja eficácia probatória passa ao iter processual, valendo como autênticos atos de prova, no sentido judicial exposto no item 6.1.1. Os atos de prova seriam, portanto, atos de instrução definitivos. ${ }^{545}$ Nesse sentido:

"Em geral, os atos do procedimento preliminar - seja ele conduzido por autoridade policial, parlamentar, judicial ou qualquer outra - são transitórios, guardam valor meramente preparatório, sendo aptos a formar um juízo provisório ou de verossimilitude suficiente para a decisão sobre medidas cautelares e sobre a abertura ou não do processo (...) Servem apenas ao procedimento investigativo, daí sua função endoprocedimental. Não passam de elementos informativos sobre a probabilidade de existência do delito e de seu autor, a serem confirmados ou não com provas produzidas em juízo. ",546

Com efeito, os atos de instrução terão caráter de definitividade sempre que não forem suscetíveis de se reproduzirem na fase processual, o que ocorre em virtude da ação do tempo, de alguma característica ínsita à medida necessária ou pelo inconveniente da espera. Sua utilização está autorizada no ordenamento pela ressalva feita no enunciado do

\footnotetext{
${ }^{545}$ SILVA, Danielle Souza de Andrade e, A investigação preliminar..., p. 168; SAAD, Marta, $O$ direito de defesa no inquérito policial..., p. 182.

${ }^{546}$ SILVA, Danielle Souza de Andrade e, A investigação preliminar..., p. 168-169. Sobre a função endoprocedimental dos atos de instrução preliminar, ver LOPES JR., Aury, Sistemas de Investigação Preliminar..., p. 140-141.
} 
artigo 155 do Código de Processo Penal e podem ser citados como exemplos o reconhecimento de pessoa ou de coisa, a busca e apreensão e as perícias. Observe-se, entretanto, que tais atos só serão convolados em atos de prova se tiverem sido produzidos em contraditório ou se este for oportunizado em momento posterior, isto é, que seja diferido, dado que o exercício do direito de defesa é essencial para que um ato de instrução seja considerado ato de prova. ${ }^{547}$

Deve-se alertar, todavia, para o fato de que a prova irrepetível não se confunde com a possibilidade de produção antecipada de provas em momento pré-processual, autorizada pelo artigo 156, inciso I do Código de Processo Penal. Esta é uma medida extraordinária, realizada perante o juiz natural com observância do contraditório efetivo. $\mathrm{O}$ ato sujeita-se à reserva de jurisdição por determinação da lei ordinária e poderá ser praticado sempre que houver fundado temor de que a prova não possa mais ser produzida no momento da instrução processual, desde que o elemento que corre o risco de perecimento apresente relevância para a solução do caso. ${ }^{548}$

Resta demonstrada, assim, a existência de atos de diversas naturezas na persecução prévia. Considerando que as observações gerais podem ser transpostas ao caso específico do inquérito parlamentar, uma vez que, além de ser procedimento administrativo, como o inquérito policial, muitas vezes acaba assumindo a natureza de efetiva investigação preliminar, passamos a aplicar as conclusões aqui apresentadas às Comissões Parlamentares de Inquérito. ${ }^{549}$

\footnotetext{
${ }^{547}$ SILVA, Danielle Souza de Andrade e, A investigação preliminar..., p. 170-171; SAAD, Marta, O direito de defesa no inquérito policial..., p. 176-182.

${ }^{548}$ SILVA, Danielle Souza de Andrade e, A investigação preliminar..., p. 172-173; LOPES JR., Aury, Sistemas de Investigação Preliminar..., p. 143.

${ }^{549}$ Interessante a exemplificação de Danielle Souza de Andrade e Silva para o melhor entendimento sobre as três espécies de atos encontrados na investigação preliminar: “... a procura de uma testemunha que venha trazer esclarecimentos ao fato, seguida de sua notificação e da tomada de seu depoimento pela autoridade condutora do procedimento, revela-se um ato de investigação; a lavratura do termo de declarações dessa testemunha, por ela assinado e acoplado aos autos da investigação, passa a constituir ato de instrução, permitindo o pleno conhecimento do investigado; no entanto, não consistirá, a princípio, em ato de prova, porque, não observando o contraditório em sua formação - já que não realizado em presença do juiz, nem com a obrigatória participação da defesa técnica - e sendo ato, por natureza, repetível na fase processual, não valerá senão como elemento de convicção, com eficácia apenas interna e restrita à etapa preliminar. ’Ver SILVA, Danielle Souza de Andrade e, A investigação preliminar..., p. 170.
} 


\subsubsection{ATOS PRATICADOS NO ÂMBITO DO INQUÉRITO PARLAMENTAR}

Fazendo um paralelo entre a investigação preliminar em sentido amplo e aquela desenvolvida no bojo do inquérito parlamentar, não podemos fugir à constatação de que os atos de investigação são aqueles direcionados à obtenção de informações sobre o fato determinado que ensejou o requerimento da constituição da Comissão Parlamentar de Inquérito, sendo que informações sobre eventual fato típico não constituem o núcleo dos trabalhos, e só serão obtidas de forma acidental. Aqui reside a maior diferença entre o inquérito parlamentar e as demais investigações preliminares de cunho penal. ${ }^{550}$

No que tange aos atos de instrução, estes também são observados nesta espécie de investigação, pois o resultado das diligências investigativas deverá, necessariamente, ser materializado. Além disso, a investigação perpetrada pelos parlamentares deverá resultar numa conclusão acerca dos fatos averiguados, formulando-se uma proposição cuja veracidade passa a ser reforçada ou afastada no desenrolar do procedimento instrutório.

Assim como a instrução do inquérito policial, não se dirige unicamente ao convencimento do magistrado, podendo fundamentar a decisão do acusador sobre apresentar ou não a denúncia, os atos de instrução em um inquérito parlamentar servem para embasar as conclusões dos próprios parlamentares componentes da Comissão, podendo, eventualmente, destinar-se a outras instituições como a Advocacia-Geral da União e o Ministério Público. Ainda, no caso de servirem de base a uma acusação, poderão ter como destinatário um membro do Poder Judiciário.

Já se sabe que no inquérito parlamentar a instauração de processo posterior não é consequiência inafastável e imperiosa. É algo que pode ou não ocorrer, a depender do material colhido mediante as investigações. Freqüentemente, o único efeito esperado dos

\footnotetext{
${ }^{550}$ Não é exagero repisar que as investigações preliminares de cunho penal sempre têm como objetivo obter indícios de autoria e materialidade de um crime, o que não é o escopo central da Comissão Parlamentar de Inquérito. Isso foi esclarecido nos momentos em que tratamos da finalidade do inquérito parlamentar, que está focada na fiscalização das atividades do Poder Executivo, razão pela qual possui natureza políticoadministrativa. Além disso, já destacamos a possibilidade do inquérito parlamentar ser autônomo.
} 
atos investigatórios e instrutórios de uma CPI é solucionar a suspeita do cometimento de irregularidades no âmbito do Poder Executivo, embasar uma decisão política, ou fundamentar a elaboração de um novo texto de lei. Todavia, o mesmo ocorre com a investigação preliminar de cunho penal quando é arquivada em virtude da ausência de elementos suficientes para a acusação.

Yuri Carajelescov pronunciou-se sobre a diferença constatada entre a fiscalização promovida mediante um inquérito parlamentar e a essência da atividade jurisdicional, que será deflagrada com base nos elementos colhidos em investigação preliminar:

"A tarefa de uma comissão parlamentar de inquérito, em suma, é reunir elementos para que o Parlamento realize a fiscalização no plano político de órgãos públicos. É investigar fatos de interesse público e reunir elementos que permitam o aprimoramento da atividade legislativa e da própria legislação. Tais atividades não se confundem, a toda evidência, com a função precípua do Judiciário, que é a de dirimir conflitos, tendo em vista a pacificação social. "551

De qualquer maneira, esses conceitos são importantes para se ter em mente que, no caso do relatório final da Comissão Parlamentar de Inquérito dar ensejo à instauração de uma ação penal, esse material só poderá ser utilizado como ato de prova se for irrepetível. Da mesma forma, vimos que no campo processual penal, o estudo da investigação preliminar apresenta relevância para evitar a indevida utilização dos elementos probatórios colhidos na fase pré-processual como fundamento de uma sentença, além de evitar a transferência do material passível de reprodução em esfera judicial. ${ }^{552}$

Não obstante, para os fins deste estudo, a adequada definição dos institutos de investigação, instrução e prova é ponto central para delinearmos o exato alcance dos

${ }^{551}$ CARAJElescov, Yuri, Comissões Parlamentares de Inquérito..., p. 171.

${ }^{552}$ SILVA, Danielle Souza de Andrade e, A investigação preliminar..., p. 175-176. 
poderes investigatórios conferidos às Comissões Parlamentares de Inquérito, o que será feito no item 6.3.

\subsection{COMPARAÇÃO DOS ATRIBUTOS ESSENCIAIS AOS EXECUTORES DA FUNÇÃO JURISDICIONAL COM AS CARACTERÍSTICAS DOS PARLAMENTARES}

Salta aos olhos o fato de que a investigação perpetrada no âmbito de uma Comissão Parlamentar de Inquérito é presidida e executada por parlamentares, isto é, membros do Poder Legislativo. Não é segredo que os parlamentares são os representantes do povo, eleitos de acordo com os mandamentos constitucionais.

Em tese, cada cidadão deveria exercer seu direito de formular leis e fiscalizar os atos do governo. Todavia, dada a impossibilidade prática de efetivar tal realidade, adota-se o sistema da democracia representativa, na qual "o povo concede um mandato a alguns cidadãos, para, na condição de representantes, externarem a vontade popular e tomarem decisões em seu nome". 553

Solucionada a maneira pela qual a democracia se operacionaliza, o que se coaduna com o modelo de justeza funcional preconizado por Canotilho ${ }^{554}$, surge outro problema: a escolha dos representantes. ${ }^{555}$ Sabemos que os motivos que levam à escolha de um

\footnotetext{
${ }^{553}$ DALlari, Dalmo de Abreu, Elementos de Teoria Geral do Estado..., p. 155.

${ }^{554}$ CANOTILHO, José Joaquim Gomes, Direito constitucional e teoria da constituição..., p. 552. Retomando o pensamento do autor: “... a cada órgão de soberania, dotado de determinadas características, é atribuída a função que ele pode desempenhar de uma forma mais adequada...” Isso significa que a função legislativa e fiscalizatória deve ser executada pelo povo e, na impossibilidade de fazê-lo, seus representantes, por ele eleitos, são os órgãos dotados das características mais adequadas ao bom desempenho da função.

555 No âmbito federal, o Poder Legislativo é composto por duas casas, a Câmara dos Deputados e o Senado Federal. A eleição de seus membros é feita de forma diferenciada, nos termos dos artigos 45 e 46 da Constituição, mas o princípio norteador é o mesmo: são eleitos aqueles que tiverem maior número de votos dentro do critério estabelecido, sempre com vistas a representar a população que os escolhe. Focamos nossa análise no funcionamento do Poder Legislativo no âmbito federal, pois o objetivo do estudo não é explicar o funcionamento do Parlamento em todas as suas instâncias, mas sim analisar a essência da função legislativa, a forma de escolha de seus membros e suas finalidades. Dito isto, temos que, na esfera federal, os Deputados são eleitos pelo sistema proporcional em cada estado e no Distrito Federal, enquanto que os senadores são eleitos pelo sistema majoritário, no número de três para cada unidade federativa.
} 
parlamentar são os mais diversos possíveis, e que o partidarismo, a paixão por ideais e outros interesses pessoais são centrais na decisão. Dalmo de Abreu Dallari já se pronunciou a respeito:

"Cada indivíduo tem suas aspirações, seus interesses e, mesmo que de maneira indefinida e imprecisa, suas preferências a respeito dos governantes. E quando se põe concretamente o problema da escolha é natural a formação de grupos de opinião, cada um pretendendo prevalecer sobre os demais. "„556

É inegável que o partido político surge como uma forma de centralizar a discussão em torno de idéias políticas. Contudo, conquanto eles possuam grande influência no cenário político e eleitoral, sabemos que as opções dos votantes raramente são baseadas unicamente em debates abstratos, e envolvem interesses dos mais diversos, financeiros, religiosos e até mesmo carismáticos, haja vista o crescente número de deputados e senadores advindos das classes artísticas no Brasil.

Outrossim, não se pode deixar de observar que, apesar do mandato político não submeter o eleito à vontade daqueles que o elegeram, isto é, embora não haja vinculação entre parlamentar e cidadão, é difícil constatar na realidade política um membro do Poder Legislativo que não se deixa influenciar pelos interesses de seu eleitorado na hora de tomar as decisões necessárias ao desenvolvimento de sua função pública.

Outro fator que merece destaque na descrição dos membros do Poder Legislativo diz respeito às condições de elegibilidade. A eleição é o meio pelo qual os representantes são escolhidos, mas não é qualquer pessoa que pode se candidatar. $\mathrm{O} \S 3^{\circ}$ do artigo 14 da Constituição Federal traz os requisitos gerais necessários para que um cidadão possa ser candidatado a qualquer cargo político. Basicamente, são eles: nacionalidade brasileira;

${ }^{556}$ DALlari, Dalmo de Abreu, Elementos de Teoria Geral do Estado..., p. 160. 
gozo dos direitos políticos; alistamento eleitoral; domicílio eleitoral na circunscrição; filiação partidária; e idade mínima variável a depender do cargo almejado. ${ }^{557}$

Essas considerações preliminares são suficientes para que tenhamos uma visão acerca das características dos componentes das Comissões Parlamentares de Inquérito. Como se percebe, a formação jurídica não lhes é exigida, e a presença de interesses e paixões é inafastável. Ainda, não é demais repisar que essas características são ideais para a consecução das funções legislativa e fiscalizatória, mas não o são para o desempenho da função jurisdicional.

Com efeito, vimos nos itens 2.5.2.3 e 3.1.1., que função jurisdicional é aquela que soluciona os conflitos de interesses em casos concretos mediante a aplicação da norma compatível com a situação e com o caráter de definitividade. ${ }^{558}$ Esta última é a grande peculiaridade da função jurisdicional em comparação à função administrativa, a qual também se funda na aplicação da lei.

Se pararmos por aqui, permaneceremos em terreno onde a interpenetração de poderes é admitida. Ainda que o Poder Judiciário seja o mais apto a praticar a função jurisdicional, e somente ele o faça com o viés da definitividade, é possível que outras autoridades solucionem conflitos de interesses mediante a aplicação do texto normativo adequado. Isso não será possível, entretanto, com relação à parcela de conflitos nos quais há um interesse público primário envolvido, quando estaremos diante de hipótese de reserva absoluta de jurisdição. ${ }^{559}$

E assim será, porque apenas os magistrados possuem determinadas características que os tornam aptos a realizar esta função de garante dos direitos fundamentais, núcleo da

\footnotetext{
557 Alguns outros requisitos e impedimentos são especificados nos demais parágrafos deste preceito legal, mas considerando que se destinam a situações específicas, entendemos não ser necessário dar-lhes especial destaque. De qualquer maneira, não é demais observar que o candidato deve ser alfabetizado; que relações de parentesco representam empecilhos em algumas situações; e que regras especiais visam à manutenção da rotatividade no governo.

${ }^{558}$ CinTrA, Antonio Carlos de Araújo, Grinover, Ada Pellegrini e DinAmarco, Cândido Rangel, Teoria Geral do Processo..., p. 38; CORTEZ, Luís Francisco Aguilar, Judiciário e Democracia..., p. 175; RANGEL, Paulo Castro, Reserva de Jurisdição..., p. 40 e 64; Mello, Celso Antonio Bandeira de, Curso de Direito Administrativo..., p. 36; e DinAmarco, Candido Rangel, Instituições de Direito Processual Civil..., p. 313314.

${ }^{559}$ Mello, Celso Antonio Bandeira de, Curso de Direito Administrativo..., p. 65; CANotilho, José Joaquim Gomes, Direito constitucional e teoria da constituição..., p. 669; RANGEL, Paulo Castro, Reserva de Jurisdição..., p. 63-64.
} 
função jurisdicional. ${ }^{560}$ Os parlamentares não detém essas peculiaridades, fato que os impede de exercer qualquer atividade cujo conteúdo se identifique com um ato exclusivamente jurisdicional. O exame de cada um dos atributos dos juízes, bem como sua comparação com a natureza de um parlamentar é essencial para o bom entendimento da questão.

Uma das características mais aclamadas do Judiciário é sua independência com relação aos demais poderes. Sem ela seria impossível efetuar um julgamento isento, pois estaria sujeito a pressões e interferências externas. Todavia, os parlamentares também possuem esse atributo na medida em que compõem o Estado Democrático de Direito e estão submetidos ao princípio geral da separação dos poderes. Mas esta é a única propriedade essencial à função jurisdicional encontrada no Parlamento.

No início deste tópico discorremos sucintamente sobre a representação política e forma de escolha desses representantes. Ficou claro que a legitimação do exercício do mandato político advém da eleição, que depende dos votos do povo, e cujo resultado está atrelado à vontade da maioria. Ao contrário, no caso do Poder Judiciário, a legitimidade externa de seu exercício não advém da escolha da maioria, mas sim da apuração imparcial dos fatos, da verdade dos pronunciamentos e da liberdade dos cidadãos. ${ }^{561}$

Para tanto, é indeclinável a detenção de saber jurídico e, no nosso ordenamento, assim como na grande maioria dos países europeus, a escolha dos indivíduos que integrarão o corpo de magistrados do país é feita através de concurso público, nos termos do inciso I do artigo 93 da Constituição Federal. ${ }^{562}$ Não é o caso dos membros do Poder Legislativo.

Deputados e Senadores são eleitos de acordo com os interesses da maioria e dela são representantes. Se atribuíssemos decisões relevantes, relativas a direitos fundamentais,

\footnotetext{
${ }^{560}$ CANOTILHO, José Joaquim Gomes, Direito constitucional e teoria da constituição..., p. 552.

${ }^{561}$ FerRAJOLI, Luigi, Jurisdição e democracia..., p. 17; FerRAJOLI, Luigi, Direito e Razão..., p. 48-49.

562 Orlando Viegas Martins Afonso afirma, oportunamente, que democracia e eleição não são sinônimos, de maneira que a escolha dos magistrados mediante concurso não afeta o princípio democrático, ao contrário, o reafirma, na medida em que possibilita a proteção dos interesses das minorias. Ver AfONSO, Orlando Viegas Martins, Poder Judicial..., p. 53. Por outro lado, Dalmo de Abreu Dallari ressalta a importância da seleção de pessoas bem capacitadas tecnicamente que também possuam sensibilidade para avaliar os comportamentos humanos, equilíbrio psicológico e firmeza ética. Cf. DALlari, Dalmo de Abreu, O Poder dos Juízes..., p. 28.
} 
a eles, autorizaríamos não apenas pronunciamentos desprovidos do necessário conhecimento jurídico, mas também contaminados com interesses políticos e partidários em detrimento de uma minoria que não os elegeu. E isso porque, além de não possuírem a devida legitimação, não são imparciais e isentos, outros atributos ínsitos aos magistrados.

Na terminologia de Paulo Castro Rangel, imparcialidade e isenção estão contidas na chamada independência subjetiva. ${ }^{563}$ Enquanto que a imparcialidade diz respeito ao distanciamento do juiz com relação às partes, de maneira a não se comprometer com o interesse de qualquer uma delas, a isenção tem a ver com o afastamento do magistrado de valores íntimos, suas paixões, simpatias e antipatias, no momento em que exerce sua função. ${ }^{564}$

Em um inquérito parlamentar não existem partes. ${ }^{565}$ Existe apenas uma comissão instituída para o fim de investigar um determinado fato. Todavia, na medida em que os trabalhos avançam e encontram-se suspeitos do cometimento de irregularidades, estes passam a ser considerados acusados no procedimento. Neste ponto a imparcialidade deveria imperar se a intenção fosse permitir que os parlamentares executassem atos típicos da jurisdição, mas não é possível, porquanto seu objetivo é justamente encontrar provas que fundamentem a suspeita que ensejou a instauração do inquérito.

Traçando um paralelo com o processo judicial, se um tribunal é instituído única e exclusivamente para o julgamento de um determinado caso, teríamos uma situação de infração à garantia do juiz natural cominada no inciso XXXVII do artigo $5^{\circ}$ da $\mathrm{CF}$ e que impede a constituição de tribunais de exceção. É corolário desta garantia que o juiz deve

\footnotetext{
${ }^{563}$ RANGEL, Paulo Castro, Reserva de Jurisdição..., p. 40-46.

${ }^{564}$ AfOnso, Orlando Viegas Martins, Poder Judicial..., p. 65-69.

${ }^{565}$ Considerando a classificação do inquérito parlamentar como investigação preliminar, cabível a ressalva de Danielle Souza de Andrade e Silva: “Consiste a investigação preliminar na etapa preparatória do processo penal, tendo por isso caráter pré-processual. Ostenta natureza procedimental, e não processual porque mesmo quando dirigida por autoridade dotada de poder jurisdicional - nela não há partes em posições contrapostas, nem contraditório pleno, nem uma acusação formal a ser decidida por um terceiro sujeito imparcial, o juiz." SILVA, Danielle Souza de Andrade e, A investigação preliminar..., p. 85.
} 
ser previamente determinado em normas de competência justamente para assegurar sua imparcialidade na apreciação do caso. ${ }^{566}$

Pois bem. Se não há determinação prévia e se a Comissão Parlamentar de Inquérito é instalada especificamente para investigar aquele fato, em momento algum seus membros serão dotados da imparcialidade necessária para executarem atos materialmente jurisdicionais, notadamente as medidas restritivas de direitos fundamentais às quais damos destaque neste estudo.

A isenção também não é característica do Parlamento. Como já dito neste item, é da natureza dos representantes do povo serem ligados a grupos de interesses e defender os propósitos de seu eleitorado com veemência. Outrossim, muitas decisões são influenciadas pelo receio de desagradar outros membros das Casas Legislativas, por questões partidárias. ${ }^{567}$ Assim, é contra sua própria essência afastar-se de valores e paixões, o que os torna impedidos de praticarem os atos próprios de juízes.

Os parlamentares carecem, ainda, das garantias conferidas aos magistrados para o bom desempenho de suas funções. O artigo 95 da Constituição Federal do Brasil confere aos juízes as garantias de inamovibilidade, irredutibilidade de subsídios e vitaliciedade. Destas, é a última que desperta maior interesse no tema em apreço, uma vez que, sendo o mandato de um membro do Poder Legislativo finito, durando de quatro a oito anos, estará ele sempre sujeito a uma reavaliação do povo para retornar ao cargo, de maneira que suas decisões podem ser viciadas pela necessidade de agradar o eleitorado.

De todo o exposto, não restam dúvidas de que os membros do Poder Legislativo não podem ser considerados aptos a praticar atos exclusivamente jurisdicionais, sobretudo no que tange a restrições de direitos fundamentais, dos quais o Judiciário é o verdadeiro garante. Concluímos com a observação de Jorge Ferreira: “... as CPI’s são órgãos

\footnotetext{
${ }^{566}$ Fernandes, Antonio Scarance, Processo Penal Constitucional..., p. 133; DINAMARCo, Cândido Rangel, Instituições de Direito Processual Civil..., p. 201; SILvA, Danielle Souza de Andrade e, A investigação preliminar..., p. $42-44$.

567 Os acordos entre as bancadas nas Casas Legislativas são prática conhecida e necessária para viabilizar a aprovação de diversos projetos de leis e outros atos normativos. Postura hostil, freqüentemente, trava os trabalhos legislativos.
} 
políticos, não sendo nem podendo transformar-se em tribunais. Daqui resulta que as CPI's não podem julgar nem condenar pessoas. ",568

\subsection{SIGNIFICADO DA EXPRESSÃO "PODERES DE INVESTIGAÇÃO PRÓPRIOS DE AUTORIDADES JUDICIAIS"}

O grande responsável pela confusão instalada acerca da extensão dos poderes dos membros das Comissões Parlamentares de Inquérito é a má redação do $\$ 3^{\circ}$ do artigo 58 da Constituição Federal do Brasil. Seu texto conferiu a estes órgãos "poderes de investigação próprios das autoridades judiciais".

A inspiração veio de textos estrangeiros, quais sejam, do artigo 82 da Constituição Italiana de 1948 e, principalmente, do artigo 178.5 da Constituição Portuguesa de 1978. Sua análise revela que o texto deste último dispositivo foi muito pouco alterado quando da transposição para a Constituição brasileira, in verbis: ${ }^{569}$

“Art. 178.5. As Comissões Parlamentares de Inquérito gozam de poderes de investigação próprios das autoridades judiciais."

Ocorre que, ao efetuar a cópia do texto transcrito acima, o constituinte errou por não ter se dado conta de que estava transferindo para o sistema processual brasileiro um mandamento de um sistema processual com fundamentos diversos, o que altera sobremaneira as conseqüências dele advindas. Além disso, o constituinte português também pecou pela falta de tecnicidade da expressão.

\footnotetext{
${ }^{568}$ FERREIRA, Jorge, Regime Jurídico dos Inquéritos Parlamentares (Anotado), Coimbra, Livraria Almedina, 1999, p. 28.

${ }^{569}$ LACAVA, Thaís Aroca Datcho, Sigilo na CPI e as garantias individuais..., p. 117.
} 
Com efeito, em Portugal, a investigação preliminar se consubstancia no inquérito, o qual é considerado um procedimento judicial pré-processual por ser dirigido pelo Ministério Público que integra o Poder Judiciário. ${ }^{570}$ Já a fase processual possui duas etapas. A primeira, destinada à investigação, é presidida por um juiz de instrução ${ }^{571} \mathrm{e}, \mathrm{a}$ segunda, na qual será efetuado o julgamento propriamente dito, é atribuída a um tribunal judicial. $^{572}$

De acordo com Jorge Figueiredo Dias, o Processo Penal português possui uma "estrutura acusatória integrada por um princípio de investigação tão lato quanto seja possivel". Isso significa que o tribunal possui o poder-dever de esclarecer e instruir a causa. $^{573}$

Explica o autor português que durante o inquérito, ao juiz de instrução cabe colher declarações para memória futura e praticar ou autorizar atos que provoquem restrições a direitos, garantias e liberdades dos indivíduos. Além disso, é ele quem preside a fase de instrução, situada entre o inquérito e o julgamento quando for necessário, para comprovar a viabilidade da acusação apresentada pelo órgão do Ministério Público. ${ }^{574}$

No plano legislativo, o artigo 17 do Código de Processo Penal Português corrobora o afirmado até aqui com o seguinte preceito: "Compete ao juiz de instrução proceder à instrução, decidir quanto à pronúncia e exercer todas as funções jurisdicionais até a remessa do processo para julgamento, nos termos prescritos por este Código”. Já os artigos 268 e 269, insertos no Capitulo "Do Inquérito", enumeram os atos praticados pelo

\footnotetext{
${ }^{570}$ LOPES JR., Aury, Sistemas de Investigação Preliminar..., p. 42 e 278.

${ }^{571} \mathrm{O}$ juiz de instrução é figura inspirada no sistema processual francês, inquisitivo em sua fase inicial, mas não se trata de figura idêntica. $\mathrm{O}$ juiz instrutor realiza todos os atos que considerar necessários ao alcance da verdade, como interrogatório, inspeções, medidas cautelares. A descrição da figura no sistema francês, feita por Valérie Dervieux é bastante elucidativa: "Ele exerce, às vezes, as funções de investigação (implicando no uso dos poderes para esta atividade) e as funções jurisdicionais, implicando, eventualmente, num poder de coerção." DERVIEUX, Valérie, O sistema francês, in Processo penal e direitos do homem: rumo à consciência européia, Delmas-MARTY, Mireille (org.), Fernando de Freitas Franco (trad.), Barueri, Manole, 2004 , p. 178.

572 De acordo com o art. $8^{\circ}$ do Código de Processo Penal Português, os tribunais judiciais é que devem decidir as causas penais.

${ }^{573}$ DIAS, Jorge Figueiredo, Os princípios estruturantes do processo e a revisão de 1998 do CPP, in Revista Portuguesa de Ciência Criminal, ano 8 Fasc. 2, Abril-jun 1998, p. 203-204.

${ }^{574}$ DIAS, Jorge Figueiredo, Os princípios estruturantes do processo..., p. 207; LOPES JR., Aury, Sistemas de Investigação Preliminar..., p. 284.
} 
juiz de instrução nesta fase, em geral, a requerimento do Ministério Público ou da autoridade policial, e aqueles que dependem de sua autorização. ${ }^{575}$

Da análise desses dispositivos, fica claro que a fase anterior ao julgamento é conduzida pelo juiz de instrução que pratica, desde atos estritamente investigatórios, como ouvir testemunhas e requerer documentos, até atos exclusivamente jurisdicionais, com vistas a resguardar os direitos dos indivíduos. Neste ponto, cumpre dar especial destaque para a redação do artigo 269, que submete à autorização judicial medidas que ensejam restrições a direitos fundamentais, como as buscas domiciliares, as escutas telefônicas e as apreensões de correspondências.

Aury Lopes Jr. descreve o papel da figura do juiz de instrução no direito português:

“...junto ao MP, intervém um juiz da instrução, com a necessária posição de garante, mas que também é chamado a praticar alguns atos específicos, que, por

\footnotetext{
${ }^{575}$ Artigo $268 .^{\circ}$ - Actos a praticar pelo juiz de instrução

1 - Durante o inquérito compete exclusivamente ao juiz de instrução:

a) Proceder ao primeiro interrogatório judicial de arguido detido;

b) Proceder à aplicação de uma medida de coacção ou de garantia patrimonial, à excepção da prevista no artigo $196 .^{\circ}$, a qual pode ser aplicada pelo Ministério Público;

c) Proceder a buscas e apreensões em escritório de advogado, consultório médico ou estabelecimento bancário, nos termos dos artigos $177^{\circ},{ }^{\circ} .^{\circ} 3,180 .^{\circ}, n .^{\circ} 1$, e $181 .^{\circ}$;

d) Tomar conhecimento, em primeiro lugar, do conteúdo da correspondência apreendida, nos termos do artigo $179 .^{\circ}, n .^{\circ} 3$;

e) Declarar a perda, a favor do Estado, de bens apreendidos, quando o Ministério Público proceder ao arquivamento do inquérito nos termos dos artigos 277. ${ }^{\circ}, 280 .^{\circ}$ e 282.

f) Praticar quaisquer outros actos que a lei expressamente reservar ao juiz de instrução.

2 - O juiz pratica os actos referidos no número anterior a requerimento do Ministério Público, da autoridade de polícia criminal em caso de urgência ou de perigo na demora, do arguido ou do assistente.

3 - O requerimento, quando proveniente do Ministério Público ou de autoridade de polícia criminal, não está sujeito a quaisquer formalidades.

4 - Nos casos referidos nos números anteriores, o juiz decide, no prazo máximo de vinte e quatro horas, com base na informação que, conjuntamente com o requerimento, lhe for prestada, dispensando a apresentação dos autos sempre que a não considerar imprescindivel.

Artigo 269. - Actos a ordenar ou autorizar pelo juiz de instrução

1 - Durante o inquérito compete exclusivamente ao juiz de instrução ordenar ou autorizar:

a) Buscas domiciliárias, nos termos e com os limites do artigo 177. ${ }^{\circ}$;

b) Apreensões de correspondência, nos termos do artigo $179 .^{\circ},{ }^{\circ}{ }^{\circ} 1$;

c) Intercepção, gravação ou registo de conversações ou comunicações, nos termos dos artigos $187 .^{\circ}$ e $1900^{\circ}$; d) A prática de quaisquer outros actos que a lei expressamente fizer depender de ordem ou autorização do juiz de instrução.

2 - É correspondentemente aplicável o disposto nos n.os 2, 3 e 4 do artigo anterior.

Extraído de http://www.legix.pt/docs/CPP.pdf Acesso em 16.02.2010.
} 
sua importância, entendeu o legislador português ser necessária a sua presença mais ativa. Por isso, classificamos a atuação do juiz em dois grupos - investigação e garantia- , mas destacamos que, apesar da aparente atividade instrutória do juiz, na verdade o protagonismo é do promotor, e que não existe a figura do juiz instrutor. Prevalece, claramente, a postura garantista "

Assim, o juiz de instrução pode praticar atos de diversas naturezas, investigatórios, instrutórios ou de prova, conforme classificação exposta no item 6.1.2. É verdade que, mesmo para ele, os atos estritamente investigatórios são excepcionais, daí a impropriedade da expressão utilizada na Constituição de Portugal. Porém, considerando o princípio de investigação que permeia o sistema português, sua atribuição neste ponto é mais alargada do que a de um sistema processual puramente acusatório. E não se deve olvidar que no momento em que o dispositivo constitucional português foi elaborado, a influência do processo de partes era mitigada, de maneira que o juiz realmente possuía mais poderes investigatórios. ${ }^{577}$ Por fim, ao juiz de instrução são atribuídos de forma exclusiva, os atos submetidos à reserva de jurisdição, por envolverem solução de conflito de interesse primário.

No entanto, ao tratar dos poderes conferidos às CPIs, o ordenamento português limitou a concessão aos poderes investigatórios, nada dizendo sobre as demais tarefas exercidas por esta figura. Dessa forma, o máximo de extensão que se pode dar ao dispositivo, é entender que o termo investigação foi usado de forma imprópria, em sentido amplo, e entender que estão abarcados os atos de instrução. ${ }^{578}$

\footnotetext{
${ }^{576}$ LOPES JR., Aury, Sistemas de Investigação Preliminar..., p. 279.

577 A Constituição Portuguesa data de 1978, enquanto que o Código de Processo Penal é de 1988, tendo sofrido uma reforma em 1995, de maneira que atualmente as regras estão mais garantistas e em direção a um sistema acusatório. Cf. LOPES JR., Aury, Sistemas de Investigação Preliminar..., p. 278. Levando em conta que nossa intenção é justamente entender o contexto em que o dispositivo transcrito para o nosso ordenamento foi criado, não podemos ignorar o fato de que se hoje o princípio da investigação ainda possui influência no sistema português, em 1978 sua força era bem maior e o juiz tinha mais poderes investigatórios. 578 Observe-se que na classificação de Aury Lopes Jr., sequer existem atos de instrução. Se aplicarmos o seu entendimento, teremos que os poderes das CPIs estarão restritos àqueles típicos da investigação preliminar. Ver nota 536. LoPes JR., Aury, Sistemas de Investigação Preliminar no Processo Penal..., p. 137-138.
} 
Jorge Miranda enumera as faculdades conferidas às Comissões Parlamentares de Inquérito no direito português da seguinte maneira: direito à coadjuvação das autoridades judiciais, dos órgãos da polícia criminal e das autoridades administrativas nos mesmos termos que os tribunais; faculdade de solicitar, por escrito, ao governo, autoridades judiciárias, órgãos da Administração ou a entidades privadas as informações e os documentos que julguem úteis; e o poder de convocar qualquer cidadão para depor. ${ }^{579}$

Não podemos interpretar extensivamente uma norma que provoque restrição a direito fundamental. Ao se interpretar o dispositivo em apreço de maneira a entender que foram conferidos todos os poderes próprios de juízes a parlamentares, estaríamos aumentando o número de agentes autorizados a efetivar restrições a direitos fundamentais, o que não é autorizado por nenhum ordenamento jurídico. Outrossim, a interpretação mais alargada atenta contra o princípio da separação dos poderes, pilar do Estado Democrático de Direito eleito pelo próprio constituinte. Assim, devemos dar à expressão "poderes de investigação" o sentido mais restrito possível, qual seja, o de que abrange somente atos exclusivamente investigatórios e instrutórios. ${ }^{580}$

Esse é o escólio de Marta Saad no que tange ao inquérito policial, instituto similar ao inquérito parlamentar, como já dito. Segundo a autora:

"Em resumo: realizam-se, no curso do inquérito, atos de investigação e atos de instrução. Primeiro, sigilosamente se investiga. Depois, praticam-se atos de instrução, por meio dos quais posteriormente o juiz molda o seu convencimento para a formação do juízo de acusação e com base nos quais também se forma o

\footnotetext{
${ }^{579}$ MIRANDA, Jorge, Sobre as Comissões Parlamentares de Inquérito em Portugal, in Revista de Direito Constitucional e Internacional, n. ${ }^{\circ}$ 33, ano 8, out-dez de 2000, São Paulo, Editora Revista dos Tribunais, p. 64 (61-67).

580 BARROSO, Luís Roberto, Comissões Parlamentares de Inquérito..., p. 72. Tercio Sampaio Ferraz Junior explica que: "Uma interpretação restritiva ocorre toda vez que se limita o sentido da norma, não obstante a amplitude de sua expressão literal. (...) Supõe, assim, que a mera interpretação especificadora não atinge os objetivos da norma, pois lhe confere uma amplitude que prejudica os interesses, ao invés de protegê-los. Assim, por exemplo, recomenda-se que toda norma que restrinja os direitos e garantias fundamentais reconhecidos e estabelecidos constitucionalmente deva ser interpretada restritivamente." FERRAZ JUNIOR, Tercio Sampaio, Introdução ao Estudo do Direito - Técnica, Decisão, Dominação, $3^{\text {a }}$ Ed. São Paulo, Editora Atlas S.A., 2001, p. 291.
} 
juízo para a decretação da prisão preventiva, do arresto e seqüestro de bens, da busca e da apreensão. ",581

Voltando ao nosso sistema, já dissemos que a fase preliminar é presidida pela autoridade policial ou administrativa, conforme artigo $4^{\circ}$ e seu Parágrafo Único do Código de Processo Penal, e quando há a necessidade de se requerer alguma medida cautelar como a prisão ou qualquer outra submetida à reserva de jurisdição, recorre-se ao magistrado competente para a eventual causa, sendo que este ficará prevento para os demais atos tanto do inquérito, quanto do processo. ${ }^{582}$

Esta sistemática foi muito criticada, uma vez que o juiz perde sua imparcialidade ao participar da investigação. ${ }^{583}$ Por tal razão, o Projeto de Lei do Senado Federal n. ${ }^{\circ}$ 156/2009, que trata do novo Código de Processo Penal, prevê a figura do juiz das garantias para o sistema brasileiro, de modo a aprimorar a consecução do princípio acusatório, pois a atividade instrutória do juiz na fase preliminar passa a ser vedada expressamente. Além disso, o magistrado que atuar como juiz das garantias não poderá participar da fase de julgamento. Privilegia-se a imparcialidade em detrimento da imediação. ${ }^{584}$

\footnotetext{
${ }^{581}$ SAAD, Marta, $O$ direito de defesa no inquérito policial..., São Paulo, p. 173-174.

${ }^{582} \mathrm{O}$ artigo 83 do Código de Processo Penal traz a regra de que será prevento o juiz que tiver praticado alguma medida relativa ao processo, ainda que anterior ao oferecimento da denúncia ou queixa. Eugenio Pacelli de Oliveira esclarece que: "a palavra medida ali empregada não pode estar se referindo a quaisquer atos investigatórios praticados no curso do inquérito ou de procedimento administrativo, mas unicamente à atuação jurisdicional, isto é, ato do juiz, no exercício da tutela da jurisdição penal" OLIVEIRA, Eugênio Pacelli de, Curso de Processo Penal..., p. 243. Nesse sentido, já se pronunciou o STF: "Prevento é o juizo da $1^{a}$ Vara Federal Criminal de São Paulo, por ter, antes de qualquer outro, despachado, determinando a quebra do sigilo bancário de co-réus em processo conexo anterior, o que impede a livre distribuição de denúncias posteriores" (HC n. ${ }^{\circ}$ 80.717/SP, rel. Sepulveda Pertence, DJ 05.03.2004).

${ }^{583}$ LOPES JR., Aury, Sistemas de Investigação Preliminar no Processo Penal..., p. 142 e 174.

${ }^{584}$ MourA, Maria Thereza Rocha de Assis, Breve notícia sobre o projeto de lei do senado federal 156/2009, que trata da reforma do código de processo penal, in Boletim IBCCrim, ano 17, n. ${ }^{\circ}$ 200, São Paulo, julho de 2009, p. 4; LOPES JR., Aury, Sistemas de Investigação Preliminar..., p. 142. Vale anotar que a vedação da prática de atos de investigação pelo juiz está consagrada no artigo $4^{\circ}$ do Projeto de Lei do Senado Federal n. ${ }^{\circ}$ 156/2009: Art. 4\%. O processo penal terá estrutura acusatória, nos limites definidos neste Código, vedada a iniciativa do juiz na fase de investigação e a substituição da atuação probatória do órgão de acusação. Já a vedação da participação do juiz das garantias no processo está no artigo 17: Art. 17. O juiz que, na fase de investigação, praticar qualquer ato incluído nas competências do art. 15 ficará impedido de funcionar no processo.
} 
A figura do juiz das garantias está delineada no artigo 15 do Projeto em comento. ${ }^{585}$ A intenção é justamente valorizar a função jurisdicional, afastando o julgador da busca de elementos de convicção, própria das partes no sistema acusatório, e destacando seu papel de protetor das liberdades individuais. O fragmento a seguir, extraído da Exposição de Motivos é bastante elucidativo sobre o papel da nova figura:

\begin{abstract}
"Para a consolidação de um modelo orientado pelo princípio acusatório, a instituição de um juiz de garantias, ou, na terminologia escolhida, de um juiz das garantias, era de rigor. Impende salientar que o anteprojeto não se limitou a estabelecer um juiz de inquéritos, mero gestor da tramitação de inquéritos policiais. Foi, no ponto, muito além. O juiz das garantias será o responsável pelo exercício das funções jurisdicionais alusivas à tutela imediata e direta das inviolabilidades pessoais. A proteção da intimidade, da privacidade e da honra,
\end{abstract}

\footnotetext{
${ }^{585}$ Art. 15. O juiz das garantias é responsável pelo controle da legalidade da investigação criminal e pela salvaguarda dos direitos individuais cuja franquia tenha sido reservada à autorização prévia do Poder Judiciário, competindo-lhe especialmente:

I - receber a comunicação imediata da prisão, nos termos do inciso LXII do art. $5^{\circ}$ da Constituição da República;

II - receber o auto da prisão em flagrante, para efeito do disposto no art. 543;

III - zelar pela observância dos direitos do preso, podendo determinar que este seja conduzido a sua presença;

IV - ser informado da abertura de qualquer inquérito policial;

$V$ - decidir sobre o pedido de prisão provisória ou outra medida cautelar;

VI - prorrogar a prisão provisória ou outra medida cautelar, bem como substituí-las ou revogá-las;

VII - decidir sobre o pedido de produção antecipada de provas consideradas urgentes e não repetíveis, assegurados o contraditório e a ampla defesa;

VIII - prorrogar o prazo de duração do inquérito, estando o investigado preso, em atenção às razões apresentadas pela autoridade policial e observado o disposto no parágrafo único deste artigo;

IX - determinar o trancamento do inquérito policial quando não houver fundamento razoável para sua instauração ou prosseguimento;

$X$ - requisitar documentos, laudos e informações da autoridade policial sobre o andamento da investigação; $X I I$ - decidir sobre os pedidos de:

a) interceptação telefônica ou do fluxo de comunicações em sistemas de informática e telemática;

b) quebra dos sigilos fiscal, bancário e telefônico;

c) busca e apreensão domiciliar;

d) outros meios de obtenção da prova que restrinjam direitos fundamentais do investigado.

XIII - julgar o habeas corpus impetrado antes do oferecimento da denúncia;

$X I V$ - outras matérias inerentes às atribuições definidas no caput deste artigo.

Parágrafo único. Estando o investigado preso, o juiz das garantias poderá, mediante representação da autoridade policial e ouvido o Ministério Público, prorrogar a duração do inquérito por período único de 10 (dez) dias, após o que, se ainda assim a investigação não for concluída, a prisão será revogada.
} 
assentada no texto constitucional, exige cuidadoso exame acerca da necessidade de medida cautelar autorizativa do tangenciamento de tais direitos individuais. ",

Conquanto o juiz das garantias ainda não seja realidade no Processo Penal brasileiro, o estudo da figura ajuda a visualizar as consequiências da adoção do sistema acusatório, que já vigora em nosso ordenamento, principalmente após as reformas empreendidas no ano de 2008. Esse ponto é fundamental para entendermos qual a exata extensão dos poderes conferidos aos membros das Comissões Parlamentares de Inquérito.

No sistema acusatório, ao juiz não são atribuídos poderes investigatórios, uma vez que há clara separação entre as funções de julgar e acusar. ${ }^{586}$ Esse foi o sistema adotado pela Constituição Federal de 1988 com relação à fase estritamente processual. Sua natureza conduz a um processo em que as partes atuam ativamente e com paridade de armas, restando ao juiz a função de julgar. No que pertine à instrução, o magistrado não possui, em regra, poder de iniciativa na obtenção de provas. ${ }^{587}$

Portanto, no Processo Penal brasileiro, não há que se falar em poderes de investigação próprios de autoridades judiciais, pois elas não os possuem. O máximo que se admite em um sistema como o nosso em termos de atuação judicial na fase preliminar é a figura do juiz das garantias, que apenas se pronunciará sobre a tutela dos direitos fundamentais. ${ }^{588}$ Já o juiz de instrução, existente no sistema português abrange não apenas

\footnotetext{
${ }^{586}$ De acordo com Rogerio Lauria Tucci, o único caso de inquérito judicial existente em nosso ordenamento, em que o juiz efetivamente preside uma investigação é o inquérito parlamentar. TUCCI, Rogério Lauria, Comissão Parlamentar de Inquérito..., p. 180.

${ }^{587}$ Afirma categoricamente Aury Lopes Jr.: "No sistema brasileiro, o juiz não investiga nada", LOPES JR., Aury, Sistemas de Investigação Preliminar..., p. 142. No mesmo sentido, SILVA, Danielle Souza de Andrade e Silva, A Atuação do juiz no processo penal acusatório..., p. 41 e 63-64; OLIVEIRA, Eugênio Pacelli de, Curso de Processo Penal..., p. 4-5. Foi dito em regra porque há situações excepcionais nas quais se admite a iniciativa instrutória do magistrado. Sobre o tema, obra de ZILLI, Marcos Alexandre Coelho, A iniciativa instrutória do juiz no processo penal, São Paulo, Editora Revista dos Tribunais, 2003. Concluiu o autor: “...a iniciativa instrutória é alimentada, não só por um poder, mas também por um dever, em uma equação de contornos notoriamente híbridos em que o dever de acertamento fático, como condição de concretização da função jurisdicional, antecede o poder, instrumentalizando-o em diferentes formas e ocasiões.” Op cit. p. 274.

588 Antes do Projeto de Lei n. ${ }^{\circ}$ 156/2009, Danielle Souza de Andrade e Silva consignou: “...no Estado Democrático de Direito, a presença do julgador ou do juiz natural na fase prévia da persecutio criminis deveria revelar-se, simplesmente, no papel de Juiz de garantias, aquele cuja atuação - afinada ao princípio acusatório e à estrutura dialética do processo penal - ficaria restrita, agindo não como investigador ou instrutor, mas tão somente como controlador da legalidade e garantidor dos direitos fundamentais do sujeito passivo." SILVA, Danielle Souza de Andrade e, A investigação preliminar..., p. 247.
} 
as funções de juiz de garantias, mas também pode praticar alguns atos tipicamente investigatórios, atuando em busca de elementos de convicção na fase de persecução prévia.

Foram os poderes conferidos a esta figura do juiz de instrução que inspiraram o mandamento constitucional português atinente aos poderes concedidos às Comissões Parlamentares de Inquérito que, por sua vez, influenciou o constituinte brasileiro e resultou no $\S 3^{\circ}$ do artigo 58, causador de tantas discussões atualmente. Logo, interpretar o dispositivo em questão sem levar em consideração toda a sistemática do Processo Penal de Portugal levará a uma conclusão equivocada e atentatória ao princípio da separação dos poderes e aos direitos fundamentais.

A confusão ficou evidente. No ordenamento jurídico brasileiro, o juiz não tem poderes investigatórios. Ao transpor a redação do preceito relativo ao direito português para nossa Constituição, surge uma dificuldade de entendimento.

Nesse sentido, Paulo Ricardo Schier constata um paradoxo constitucional, pois o mesmo sistema que cada vez mais retira os poderes instrutórios do juiz concede poderes de investigação ao Parlamento que os magistrados, em tese, não possuem. Há que se fazer um esforço hermenêutico para harmonizar o mandamento $\$ 3^{\circ}$ do artigo 58 com a vocação acusatória do sistema processual brasileiro. ${ }^{589}$

Não resta alternativa que não buscar socorro no sistema português e em sua figura do juiz de instrução. Como dito, o juiz de instrução pode praticar atos de diversas naturezas no desempenho de sua função, dentre os quais se encontram os atos de investigação e instrução. Ao destacar os poderes de investigação no artigo referente às Comissões Parlamentares de Inquérito, o constituinte português quis excluir os demais atos pertencentes ao núcleo da função jurisdicional, destacando-se aqueles com potencial para limitar direitos e garantias fundamentais.

Essa é a melhor interpretação, que se coaduna com todo o sistema brasileiro. Isso porque, sendo o inquérito parlamentar uma espécie de investigação preliminar, quando não se trata apenas de um procedimento político-administrativo, não podem seus membros

${ }^{589}$ SCHIER, Paulo Ricardo, As Comissões Parlamentares de Inquérito e a Defesa dos Direitos Individuais, in Revista da Academia Brasileira de Direito Constitucional, V. 3, 2003, p. 277-278. 
possuir mais poderes do que a autoridade policial possui na condução de um inquérito policial. A atividade desenvolvida no bojo de um inquérito parlamentar aproxima-se mais daquela realizada em um inquérito policial do que a função desenvolvida por um magistrado na fase de instrução processual em um sistema acusatório em que as partes são responsáveis pela colheita das provas. ${ }^{590}$

É verdade que, de forma excepcional, admite-se que o magistrado tome a iniciativa instrutória, ou seja, determine a realização de diligências que entender indispensáveis para a elucidação do caso. É corolário do novo preceito contido no inciso II do artigo 156, segundo o qual o juiz passa a ter a possibilidade de robustecer o conjunto probatório para o melhor desempenho de sua função constitucional. ${ }^{591}$ Nos termos de Marcos Alexandre Coelho Zilli, trata-se de forma de se atingir o melhor acertamento fático, com vistas a preservar os interesses considerados relevantes pelo Estado: "a manutenção da ordem jurídica e social e a preservação da liberdade jurídica do cidadão. ",592

Mas neste caso, não se trata de mera atividade investigatória, em que se averiguam todas as possibilidades, colhendo os mais diversos elementos que possam levar a uma conclusão sobre a autoria e materialidade de um crime e, conseqüentemente, embasar uma acusação. Trata-se da busca de elementos úteis para melhor aclarar os fatos tomando por base uma afirmação inicial delineada pela acusação, já na fase judicial. ${ }^{593}$

Fazendo o paralelo necessário com a Comissão Parlamentar de Inquérito, a elas são conferidos apenas os poderes de investigar o fato determinado, o qual desencadeia uma série de linhas de investigação, ensejando a colheita de elementos probatórios de forma a se formular uma primeira hipótese do que possa ter ocorrido. Também são conferidos poderes instrutórios, na medida em que o resultado das diligências vai sendo reduzido a

\footnotetext{
${ }^{590}$ PIтомво, Cleunice A. Valentim Bastos, Comissão Parlamentar de Inquérito..., p. 275; LACAVA, Thaís Aroca Datcho, Sigilo na CPI e as garantias individuais..., p. 127. No item relativo ao papel do juiz contido em livro sobre os Processos Penais da Europa, afirma-se que nos países estudados a função de investigação é desempenhada pela polícia, o que reafirma nossa tese de que o inquérito parlamentar como forma de investigação aproxima-se mais de um inquérito policial do que de um processo judicial. SALES, Denis, $O$ Papel do Juiz, in Processo penal e direitos do homem: rumo à consciência européia, DELMAS-MARTY, Mireille (org.), Fernando de Freitas Franco (trad.), Barueri, Manole, 2004, p. 528.

${ }^{591}$ SILVA, Ivan Luís Marques da, Reforma Processual Penal de 2008: Lei 11.719/2008, procedimentos penais: Lei 11.690/2008, provas: Lei 11.689/2008, júri: comentadas artigo por artigo, São Paulo, Editora Revista dos Tribunais, 2008, p. 64-66.

${ }_{592}^{5 I L L I}$, Marcos Alexandre Coelho, A iniciativa instrutória do juiz..., p. 124.

${ }^{593}$ Idem, p. 117.
} 
termo, atividade que culmina com o Relatório Final, onde já estará elaborada uma proposição acerca da pesquisa perpetrada. ${ }^{594}$

Essas definições são muito relevantes para entendermos a exata definição dos poderes de investigação, mas o ponto central é definir que as Comissões Parlamentares de Inqérito não podem decidir acerca de medidas restritivas de direito como entende grande parte da doutrina e dos tribunais. Seus poderes instrutórios não possibilitam que executem medidas cautelares, determinem prisões nem determinem a realização de meios de prova ou de obtenção de prova que resultem em invasão a direitos fundamentais.

Esse é o tema específico do próximo tópico. Antes, porém, merece transcrição a observação de Rogério Lauria Tucci, que bem delimitou o teor do $\$ 3^{\circ}$ do artigo 58 , e proporciona um bom fechamento às considerações aqui tecidas. Observe-se que o autor utiliza a expressão poderes de investigação como no texto constitucional, mas podemos entender que abarca os atos meramente instrutórios, conforme tudo o que foi exposto:

"Em epítome, e qualquer que seja o ângulo de visualização, à comissão parlamentar de inquérito são conferidos, no âmbito de sua atuação específica, tãosomente 'poderes de investigação', inclusive os 'próprios de autoridades judiciais' em sua anômala atividade investigatória, e, portanto, restritos à elencação legalmente estabelecida, naquilo que consonante com a preceituação constitucional determinante de sua instituição. "595

\footnotetext{
${ }^{594}$ Nessa direção, Gustavo Badaró: “Mas sem dúvida, os juízes, no desempenho da função jurisdicional, têm poderes para determinar a produção de provas, para a instrução do processo. Estes poderes, e somente esses poderes, é que foram conferidos às comissões de inquérito. As comissões de inquérito, portanto, não dispõem de todos os poderes de que são investidas as autoridades judiciais, mas apenas de seus poderes instrutórios. "CF. BADARÓ, Gustavo Henrique Righi Ivahy, Limites aos poderes investigatórios..., p. 11-12. ${ }^{595}$ TUCCI, Rogério Lauria, Comissão Parlamentar de Inquérito..., p. 181.
} 


\subsection{APLICAÇÃO DA CLÁUSULA DE RESERVA DE JURISDIÇÃO NO INQUÉRITO PARLAMENTAR}

Definida a extensão dos poderes conferidos às Comissões Parlamentares de Inquérito pelo texto da Constituição Federal do Brasil, cumpre compatibilizar essa conclusão com o conceito de reserva de jurisdição proposto neste estudo para que se defina, expressamente, quais atos são ou não praticáveis no decorrer de um inquérito parlamentar.

A definição acerca da extensão dos poderes previstos no $\S 3^{\circ}$ do artigo 58 da $C F$ não é suficiente para que se determine os atos que podem ser praticados pelas Comissões Parlamentares de Inquérito e quais estarão sujeitos à autorização judicial para sua concretização.

Com efeito, muitos autores e julgadores compartilham da opinião aqui exposta sobre o significado da expressão poderes investigatórios, mas acabam entendendo que alguns atos que ensejam medidas restritivas de direito podem ser praticados pelos parlamentares. Outros, ainda, até excluem da competência dos membros da comissão os atos sujeitos à reserva de jurisdição, mas não aceitam a idéia de reserva de jurisdição implícita, o que os leva à conclusão de que as CPIs podem, por exemplo, efetivar a quebra do sigilo bancário sem prévia ordem judicial. ${ }^{596}$

Do exposto, depreende-se, portanto, que definir os parâmetros para a aplicação da cláusula de reserva de jurisdição no âmbito do inquérito parlamentar, não depende apenas de definir o significado dos poderes investigatórios de autoridades judiciais, mas também de assentar a idéia aqui preconizada de que os casos de reserva de jurisdição não são apenas aqueles previstos expressamente em algum texto legal, existindo, também, as

\footnotetext{
${ }^{596}$ Cleunice Pitombo tece algumas considerações sobre a contradição de alguns autores e, sobretudo, julgadores: "Na melhor doutrina, a divergência sobre os limites investigatórios da comissão parlamentar de inquérito desponta pequena. Nos julgados, entretanto, muitas vezes, é conflitante com a decisão final, ou conclusão. Veja-se, por exemplo, o acórdão proferido pelo Supremo Tribunal Federal que abaixo se transcreve, em parte. No seu corpo, a análise é sempre limitativa. Afirma, de modo expresso, que os poderes são restritos e que os direitos fundamentais devem ser respeitados; mas admite a busca e a apreensão, sem licença do Poder Judiciário, de maneira antitética." Ver PIтомBo, Cleunice A. Valentim Bastos, Comissão Parlamentar de Inquérito..., p. 277-278.
} 
hipóteses de reserva implícita, decorrente do sistema, cujos critérios foram definidos no item 3.3.

Posto isso, cumpre expor as idéias encontradas na doutrina. Três são as correntes identificadas: a da negação da reserva de jurisdição; a da reserva de jurisdição restrita e a da reserva de jurisdição ampla. Luiz Carlos dos Santos Gonçalves e Paulo Hamilton Siqueira Jr. filiam-se à primeira corrente e defendem a total equiparação entre Comissões Parlamentares de Inquérito e Poder Judiciário no que tange a atos probatórios, admitindo a quebra de sigilo bancário, a determinação de busca e apreensão e até mesmo a quebra de sigilo das comunicações telefônicas por parte dos parlamentares. Ambos afirmam expressamente que a cláusula de reserva de jurisdição não se aplica às Comissões Parlamentares de Inquérito. ${ }^{597}$

A corrente intermediária é aquela que, conquanto entenda que a expressão poderes de investigação próprios de autoridade judicial abrange apenas os atos de investigação e instrução, tem uma visão mais legalista sobre a reserva de jurisdição, reconhecendo-a apenas nos casos em que a Constituição ou a lei exige expressamente uma autorização judicial prévia.

Paulo Ricardo Schier é um dos que afirma categoricamente que:

“algumas medidas probatórias autorizadas aos magistrados penais ainda não serão extensíveis as CPIs em face da chamada reserva de jurisdição. Seria o caso, por exemplo, da busca domiciliar, a interceptação telefônica em sentido próprio (escuta) e a decretação de prisão de qualquer pessoa (salvo em flagrante delito). ",598

\footnotetext{
${ }^{597}$ SiqueIRA JR., Paulo Hamilton, Comissão Parlamentar de Inquérito..., p. 80; GONÇALVES, Luiz Carlos dos Santos, Poderes de Investigação das Comissões Parlamentares..., p. 66 e 68. Na jurisprudência, encontramos o HC 71.039, Rel. Min. Paulo Brossard, DJ de 14.04 .94 trazendo posição similar a esta. O teor do acórdão revela o entendimento de que as Comissões Parlamentares de Inquérito estão autorizadas a efetuar a busca e apreensão sem prévia decisão judicial.

${ }^{598}$ SCHIER, Paulo Ricardo, As Comissões Parlamentares de Inquérito..., p. 279.
} 
Observe-se que todas as hipóteses de reserva de jurisdição mencionadas pelo autor são constitucionais, isto é, estão previstas na Lei Maior. Apesar de reconhecer a existência de atos exclusivamente jurisdicionais, o autor confere esta natureza apenas àqueles assim declarados pela lei, entendendo ser possível a pratica de outros atos pelas CPIs que, embora restrijam direitos fundamentais, não possuem o requisito legal de prévia ordem judicial. Assim, defende a possibilidade das Comissões Parlamentares de Inquérito efetuarem a quebra de sigilo de dados, de sigilo financeiro, de sigilo fiscal e do sigilo dos dados telefônicos. ${ }^{599}$

O mesmo raciocínio é adotado por diversos autores, nomeadamente, Gustavo Badaró, Antonio Scarance Fernandes, Carlos Mário Velloso, Cássio Juvenal Faria e Luiz Flavio Gomes e Yuri Carajelescov. Todos estes estudiosos reconhecem a existência do instituto da reserva de jurisdição, assim como defendem sua aplicação na investigação levada a cabo pelas Comissões Parlamentares de Inquérito. Todavia, fazem-no apenas para os casos em que a decisão judicial é exigida expressamente no texto constitucional e legal, consentindo com a possibilidade de parlamentares perpetrarem restrições a direitos fundamentais nos demais casos. ${ }^{600}$

Esse entendimento é o adotado no leading case da matéria, o Mandado de Segurança n. ${ }^{\circ}$ 23.452/RJ, julgado pelo STF, bem como é o que vem predominando nos Tribunais Superiores. Neste acórdão, cujo relator foi o Min. Celso de Mello, cinco Ministros reconheceram expressamente a existência da cláusula de reserva de jurisdição ${ }^{601}$,

\footnotetext{
599 SCHIER, Paulo Ricardo, As Comissões Parlamentares de Inquérito..., p. 285-287. Interessa destacar a diferenciação feita entre sigilo das comunicações telefônicas, objeto de proteção do art. $5^{\circ}$, XII, da CF, e sigilo dos dados telefônicos, referente aos registros da ligações efetuadas e recebidas, o qual seria uma espécie do sigilo de dados, e não estaria abarcado pela exigência de ordem judicial prévia na visão deste autor.

600 BADARÓ, Gustavo Henrique Righi Ivahy, Limites aos poderes investigatórios...; FERNANDES, Antonio Scarance, $O$ sigilo financeiro e a prova criminal, in CostA, José Faria da, e SILVA, Marco Antonio Marques da (coord.), Direito Penal Especial, Processo Penal e Direitos Fundamentais - visão luso-brasileira, São Paulo, Editora Quartier Latin, 2006, p. 479; Velloso, Carlos Mário, da S., As Comissões Parlamentares de Inquérito e o sigilo das comunicações telefônicas, in Revista Brasileira de Ciências Criminais, ano 6, n..$^{\circ} 24$, out.-dez. 1998, p. 142; FARIA, Cássio Juvenal e GoMES, Luiz Flávio, Poderes e limites das CPIs...,; CARAJElescov, Yuri, Comissões Parlamentares de Inquérito..., p. 127-132, 145 e 153.

601 “O postulado da reserva constitucional de jurisdição importa em submeter, à esfera única de decisão dos magistrados, a prática de determinados atos cuja realização, por efeito de explícita determinação constante do próprio texto da Carta Política, comente pode emanar do juiz, e não de terceiros, inclusive daqueles a quem se haja eventualmente atribuido o exercício de 'poderes de investigação próprios das autoridades judiciais” MS 23.452, Rel. Min. Celso de Mello, DJ de 12.05.2000.
} 
sendo que os demais se abstiveram de tratar do tema em virtude da falta de fundamentação da decisão da CPI ser suficiente para a concessão da ordem.

A ementa do julgado é bastante complexa e divide-se em tópicos. Naquele relativo à reserva de jurisdição, explicita-se o entendimento de que a ela estão submetidos a busca domiciliar, a interceptação telefônica e a decretação de prisão. Todavia, ao tratar sobre o sigilo bancário, fiscal e telefônico, afirma:

"O sigilo bancário, o sigilo fiscal e o sigilo telefônico (sigilo este que incide sobre os dados/registros telefônicos e que não se identifica com a inviolabilidade das comunicações telefônicas) - ainda que representem projeções específicas do direito à intimidade, fundado no art. $5^{\circ}, X$, da Carta Política $\neg-$ não se revelam oponíveis, em nosso sistema jurídico, às Comissões Parlamentares de Inquérito, eis que o ato que lhes decreta a quebra traduz natural derivação dos poderes de investigação que foram conferidos, pela própria Constituição da República, aos órgãos de investigação parlamentar. "602

Por fim, temos a corrente ampla da reserva de jurisdição, que não só a reconhece quando explícita no ordenamento, mas também quando é extraída de forma implícita dos princípios norteadores do sistema jurídico brasileiro, nos termos do que é defendido por Canotilho. ${ }^{603}$ Esta é a corrente a qual nos filiamos, haja vista tudo o que foi exposto no Capítulo 3, sobretudo no item 3.3, no qual estabelecemos os critérios capazes de identificar uma situação que deve ser submetida à reserva de jurisdição, concluindo que tal se dará quando nos depararmos com uma situação que ensejar a limitação de um direito fundamental ou outro bem constitucionalmente protegido, em decorrência de um conflito de interesses que só pode ser solucionado de forma definitiva pelo Poder Judiciário.

${ }^{602}$ STF MS 23.452, Rel. Min. Celso de Mello, DJ de 12.05.2000.

${ }^{603}$ CAnotillo, José Joaquim Gomes, Direito constitucional e teoria da constituição..., p. 669. 
Nesse sentido, além de não poder determinar interceptações telefônicas, busca domiciliar, condução coercitiva de testemunha e prisão, as Comissões Parlamentares de Inquérito também não podem efetuar a quebra de sigilo financeiro ou de outros dados, porquanto são situações submetidas à reserva de jurisdição, por tudo o que expusemos no Capítulo 4. Esse é o entendimento preconizado por Rogerio Lauria Tucci, Marta Saad, Cleunice Pitombo, José Alfredo de Oliveira Baracho, Luis Roberto Barroso, Thais Aroca Lacava. ${ }^{604}$ Para atestar o afirmado, transcrevemos as considerações de um dos autores:

“...em vista da limitação dos poderes da Comissão Parlamentar aos de uma autoridade policial quando determinado direito fundamental está em jogo, tal como a liberdade ou a privacidade, somente a autoridade judicial poderá autorizar a sua restrição, explicitando o motivo e os fundamentos da medida. "605

Com efeito, é perfeitamente possível defender, no conjunto normativo que possuímos hoje, a aplicação cláusula de reserva de jurisdição para todos os casos em que houver risco de restringir direitos e garantias fundamentais, por tudo o que foi exposto. De qualquer maneira, o Projeto de Lei do Senado Federal n. ${ }^{\circ}$ 156/2009, que pretende promover a alteração do Código de Processo Penal, corrobora nossa tese. Isso porque o artigo 15 do referido projeto, que traz a figura do juiz de garantias já tratada no item 6.3., prevê, em seu inciso XII que a este magistrado incumbe:

"XII - decidir sobre os pedidos de:

a) interceptação telefônica ou do fluxo de comunicações em sistemas de informática e telemática;

\footnotetext{
${ }^{604}$ TUCCI, Rogério Lauria, Comissão Parlamentar de Inquérito..., p. 181; SAAD, Marta, O direito de defesa no inquérito policial..., p. 121; PIтомBO, Cleunice A. Valentim Bastos, Comissão Parlamentar de Inquérito..., p. 276; BARACHO, José Alfredo de Oliveira, As Comissões Parlamentares na Constituição de 1988..., p. 58; BARroso, Luís Roberto, Comissões Parlamentares de Inquérito..., p. 73; LACAVA, Thaís Aroca Datcho, Sigilo na CPI e as garantias individuais..., p. 120 e 124-125.

${ }^{605}$ SAAD, Marta, O direito de defesa no inquérito policial..., p. 120-121;
} 
b) quebra dos sigilos fiscal, bancário e telefônico;

c) busca e apreensão domiciliar;

d) outros meios de obtenção da prova que restrinjam direitos fundamentais do investigado."

Note-se que serão submetidos à autorização judicial prévia não apenas o sigilo fiscal, bancário e telefônico que dividiam as correntes restritiva e ampla, mas também todos os meios de prova que promoverem intervenção em direitos fundamentais, de maneira que a reserva de jurisdição será positivada de maneira ampla.

\subsection{ATOS QUE PODEM SER PRATICADOS PELAS COMISSÕES PARLAMENTARES DE INQUÉRITO}

Até aqui foi dado enfoque aos atos que não podem ser praticados pelas Comissões Parlamentares de Inquérito na execução de suas atividades de investigação. Cumpre, agora, enfatizar quais os atos que podem ser perpetrados sem que se invada o núcleo da função jurisdicional.

$\mathrm{O}$ artigo $2^{\circ}$ da Lei n. $^{\circ} 1.579 / 52$ enumera os atos dos quais as Comissões Parlamentares de Inquérito podem valer-se no desempenho de suas atribuições, referindose à determinação de diligências que entenderem necessárias, à convocação de Ministros de Estado, à tomada de depoimento de quaisquer autoridades federais, estaduais ou municipais, à oitiva de indiciados, à inquirição de testemunhas, à requisição de informações e documentos perante repartições públicas e autárquicas e ao transporte para os locais que sua presença se fizer necessária.

Rogerio Lauria Tucci acrescenta, ainda, a incumbência de solicitar ao Tribunal de Contas da União, órgão auxiliar do Legislativo na função fiscalizatória, as inspeções e 
auditorias imprescindíveis à realização de seus trabalhos. ${ }^{606}$ Cleunice Pitombo, por sua vez, menciona a determinação de perícia como espécie de diligência que pode ser determinada pelos parlamentares. ${ }^{607}$

Por fim, Luís Roberto Barroso faz alusão à determinação de exibição de documentos privados, ao lado da requisição de documentos públicos. Note-se que a utilização de termos diversos deve-se ao fato de que o particular não pode ser compelido a apresentar documentos acobertados pelo sigilo decorrente de seu direito à intimidade. No entanto, pode abdicar desse direito e apresentar a documentação solicitada voluntariamente se for de seu interesse. ${ }^{608}$

O autor elabora interessante raciocínio para afirmar que as determinações das Comissões Parlamentares de Inquérito são dotadas de imperatividade, mas não são autoexecutáveis. Isso significa que suas intimações, requisições e outros atos relativos à investigação devem ser cumpridos por seus destinatários e, caso não sejam, poderão ser acionados os meios coercitivos, sujeitos à prévia avaliação judicial, porquanto ensejam intervenção na esfera individual. ${ }^{609}$

É patente que os poderes de investigação não se confundem com as competências jurisdicionais em sentido material, ou seja, não devem se pronunciar acerca da norma jurídica aplicável a um caso, não devem julgar, condenar ou absolver. Além disso, também não possuem o poder de cautela, não podendo determinar medidas com prisão provisória ou indisponibilidade de bens, devendo requerê-las ao juiz competente se necessário, de maneira que lhes é permitido formular o pedido para atingir essas finalidades. ${ }^{610}$

No transcurso do inquérito parlamentar, na medida em que as investigações avançam e as informações vão sendo reveladas, são os parlamentares, isto é, os investigadores, que farão a avaliação sobre a necessidade de uma diligência. Os membros

\footnotetext{
${ }^{606}$ TUCCI, Rogério Lauria, Comissão Parlamentar de Inquérito..., p. 181.

${ }^{607}$ Pitombo, Cleunice A. Valentim Bastos, Comissão Parlamentar de Inquérito..., p. 276.

${ }^{608}$ BArroso, Luís Roberto, Comissões Parlamentares de Inquérito..., p. 83.

${ }^{609}$ Idem, p. 73.

${ }^{610}$ BARroso, Luís Roberto, Comissões Parlamentares de Inquérito..., p. 83; SCHIER, Paulo Ricardo, As Comissões Parlamentares de Inquérito..., p. 279. No sentido de que poderes instrutórios não abrangem a possibilidade de decretar a indisponibilidade de bens, o julgado STF MS 23.480, Rel. Min. Sepúlveda Pertence, $D J$ de 15.09.00.
} 
da CPI realizam uma atividade de inteligência, aventam possibilidades, fazem deduções e vão definindo os rumos que a investigação deve tomar. Todavia, ao se deparar com a necessidade de efetivar uma medida que implicará uma restrição a direito fundamental, seu dever será fazer o requerimento, de forma fundamentada e devidamente deliberada, para que a autoridade judiciária competente possa sopesar os valores envolvidos e decidir acerca de seu cabimento. Logo:

“... as CPI's têm amplos poderes de investigação, que exercem iure próprio, com base no art. 58, $\$ 3^{\circ}$, da Lei Maior. Apenas nos casos de superação de injusta resistência-e.g., recusa de testemunha em comparecer, recusa na apresentação de um documento requisitado - ou de necessidade de interferir com direitos protegidos constitucionalmente, cuja vulneração exija devido processo legal - e.g., busca domiciliar, quebra de sigilo bancário e outros - é que deverão requerer seja expedida ordem judicial. E, apresentados elementos que razoavelmente fundamentem a pretensão, deve o Judiciário deferi-la. ",611

\subsection{O DESRESPEITO À CLÁUSULA DE RESERVA DE JURISDIÇÃO NO INQUÉRITO PARLAMENTAR - CONSEQÜÊNCIAS E REMÉDIOS}

Se os membros de uma Comissão Parlamentar de Inquérito entendem ser necessário efetivar uma medida restritiva de direito fundamental para dar prosseguimento à investigação e conseguem que a instituição responsável por sua efetivação obedeça a sua ordem, estaremos diante de um ato inconstitucional, já que, em última instância, o desrespeito à reserva de jurisdição sempre implicará uma violação da ordem constitucional,

${ }^{611}$ BARroso, Luís Roberto, Comissões Parlamentares de Inquérito..., p. 84-85. 
ainda que não prevista expressamente, porquanto se trata de uma restrição a direito fundamental por órgão que não possui competência para tanto. É um atentado ao Estado Democrático de Direito e um de seus pilares, a separação dos poderes. O ato também será ilegal em sentido estrito no caso de se tratar de uma reserva de jurisdição legal, como a que se refere ao sigilo das comunicações telefônicas.

Em qualquer um desses casos, poder-se-á utilizar o remédio constitucional previsto para a prática de atos ilegais por parte de autoridades públicas, qual seja, o mandado de segurança. Com efeito, o inciso LXIX da Constituição dispõe:

“conceder-se-á mandado de segurança para proteger direito líquido e certo, não amparado por habeas corpus ou habeas data, quando o responsável pela ilegalidade ou abuso de poder for autoridade pública ou agente de pessoa jurídica no exercício de atribuições do poder público."

Considerando que uma medida perpetrada no bojo de um inquérito parlamentar não representa, de plano, um risco ao direito de locomoção, que autorizaria o uso do habeas corpus, resta recorrer ao remédio constitucional subsidiário, isto é, ao mandado de segurança, admitindo-se, também, que o remédio seja utilizado de forma preventiva, na tentativa de se impedir a prática do ato de restrição a direito fundamental sem observância da cláusula de reserva de jurisdição. ${ }^{612}$

O impetrado deverá ser o Presidente da Comissão Parlamentar de Inquérito, representante do órgão colegiado que toma as decisões restritivas de direito ${ }^{613}$, e a

\footnotetext{
${ }^{612}$ MourA, Maria Thereza Rocha de Assis, Meios de impugnação à quebra indevida de sigilo bancário..., p. 179; Belloque, Juliana Sigilo bancário..., p. 175-176; CARAJELESCOV, Yuri, Comissões Parlamentares de Inquéritop. 188.

${ }^{613}$ BARACHO, José Alfredo de Oliveira, As Comissões Parlamentares na Constituição de 1988..., p. 64. O autor menciona o MS 23.444, julgado no STF, no qual o Presidente da CPI foi o único impetrado mantido no pólo passivo da ação (apreciação de liminar pelo Rel. Mauricio Corrêa, DJ 27.05.99). No mesmo sentido, CARAJelescov, Yuri, Comissões Parlamentares de Inquérito..., p. 187.
} 
competência para o julgamento dessa ação constitucional será do Supremo Tribunal Federal, conforme ensina Cretella Junior. ${ }^{614}$

Vislumbra-se, ainda, outra possibilidade de impugnar um ato de Comissão Parlamentar de Inquérito que atentar contra a cláusula de reserva de jurisdição nos casos em que esta visar à proteção do direito à intimidade, como ocorre em todas as previsões de sigilo. Esta assentada no artigo 21 do Novo Código Civil. Reza o dispositivo legal:

“Art. 21. A vida privada da pessoa natural é inviolável, e o juiz, a requerimento do interessado, adotará as providências necessárias para impedir ou fazer cessar ato contrário a esta norma."

A violação ilícita da vida privada por membro do Parlamento possibilita que o interessado, isto é, o sujeito ativo do sigilo, requeira ao juiz competente a adoção de medidas para impedir o ato da CPI ou, se já efetivado, para evitar que qualquer consequiência danosa que dele advenha, determinando-se o desentranhamento dos dados.

Por outro lado, no caso do ato inconstitucional ter sido aperfeiçoado, do material dele resultante não ter sido desentranhado dos autos do inquérito parlamentar e deste ter sido encaminhado ao Ministério Público com o escopo de promover uma acusação criminal, passamos a vislumbrar a possibilidade de restrição do direito de locomoção do indivíduo envolvido na investigação, pois há um risco de condenação à pena privativa de liberdade, o que autoriza o uso do habeas corpus.

Por derradeiro, outra possibilidade de uso do habeas corpus é na decretação de prisão por parte da Comissão Parlamentar de Inquérito, o que só se admite no caso de

\footnotetext{
${ }^{614}$ CRetella Junior, J., Comissão Parlamentar de Inquérito (CPI), in Revista Forense, Vol. 353, Jan-fev 2001, Rio de Janeiro, p. 453. É o mandamento contido no artigo 102, I, $d$ e $i$ da Constituição, o que já foi reconhecido pelo STF no MS 23.452, Rel. Min. Celso de Mello, DJ de 12.05.2000. Cf. CARAJELESCOV, Yuri, Comissões Parlamentares de Inquérito..., p. 188.
} 
flagrante delito, já que as prisões dependem de ordem judicial por dispositivo constitucional. $^{615}$

${ }^{615}$ CARAJElescov, Yuri, Comissões Parlamentares de Inquérito..., p. 190. 


\section{CONCLUSÃO}

A reserva de jurisdição é um instituto cujo aparato teórico ainda é incipiente. Esse trabalho teve o objetivo de apresentar algumas sugestões para o aprofundamento de sua compreensão, de maneira a fomentar o debate sobre o tema e, ao final, alcançar soluções mais consentâneas com a proteção dos direitos fundamentais, notadamente, por meio da positivação de mais hipóteses em que a decisão judicial prévia faz-se necessária, mas também pela disseminação da idéia de que o monopólio da primeira palavra pode ser extraído do sistema nos casos em que não estiver explicitamente previsto.

O Estado Democrático de Direito é construído sobre o princípio da separação de poderes que evoluiu para admitir uma interpenetração entre as funções estatais. Todavia, há um limite intransponível para esse intercâmbio de competências, qual seja, o núcleo essencial de cada função. Isso porque, de acordo com o modelo de justeza funcional desenvolvido por Canotilho, cada tarefa deve ser executada pelo órgão estatal que possui a estrutura mais adequada para tanto.

A função jurisdicional pode ser conceituada como aquela que soluciona os conflitos de interesses de forma definitiva, por meio da aplicação da lei. Em tese, outros órgãos poderão exercer essa função de resolução de conflitos mediante a subsunção dos fatos às normas, embora apenas o Judiciário possa fazê-lo de forma definitiva, isto é, dar ao caso à condição de coisa julgada e imutável.

No entanto, existe um núcleo dentro dessa função jurisdicional, denominado essencial, que só pode ser realizado pelo Poder Judiciário, órgão adequadamente aparelhado para tanto. Nesse caso, os conflitos a serem solucionados envolvem um interesse público primário, cuja importância impede a atuação de qualquer outro órgão na execução dessa atividade.

Esse é o ponto de partida para a compreensão da idéia de reserva de jurisdição, a qual se subdivide em absoluta e relativa. Nos casos em que outros órgãos podem intervir, mas fica resguardada a possibilidade do Judiciário pronunciar-se ao final, há o monopólio 
da última palavra ou reserva de jurisdição relativa. Já nos casos em que o conflito existente envolve um interesse de significativa relevância, em geral, um direito fundamental, apenas o Poder Judiciário poderá se manifestar desde o primeiro momento, emergindo o monopólio da primeira palavra ou reserva de jurisdição absoluta.

A teoria é necessária, porém não é suficiente. De nada adianta definir o instituto da reserva de jurisdição se não forem estabelecidos os casos em que se aplica. A solução é facilitada nos casos em que há previsão expressa no ordenamento, seja ela constitucional, seja legal. No entanto, duas perguntas apresentam-se: existe reserva de jurisdição implícita? E se existe, quais os critérios para definir as situações em que será demandada?

A tese aqui defendida é de que todos os casos nos quais houver conflitos de interesses envolvendo bens constitucionalmente protegidos ou direitos fundamentais dependerão de manifestação do Poder Judiciário, que elegerá a norma apta a solucioná-los de forma definitiva. Isso significa que a positivação não é fator indispensável para o reconhecimento da reserva de jurisdição, podendo ser extraída do sistema jurídico. Portanto, estamos de acordo com a existência de reserva de jurisdição implícita.

Para alcançar a definição dos casos que a ela se submetem, investigamos as razões pelas quais é necessário haver no sistema um núcleo de atividades reservadas a um determinado órgão, explicando as características que fazem do Judiciário o órgão adequado para desenvolver a função de resolução de conflitos relevantes de maneira definitiva, discorremos sobre a natureza dos direitos fundamentais e a forma de resolução das colisões entre eles e analisamos as decorrências do devido processo legal.

O Poder Judiciário é a instituição mais apta a decidir sobre conflitos que envolvam intervenções em direitos fundamentais por possuir as características da independência, imparcialidade e isenção. As decisões serão justas apenas se o órgão incumbido de tomálas for separado dos demais e livre de influências, sejam elas de partes processuais, sejam de valores sociais ou pessoais.

O exame da essência dos direitos fundamentais, por outro lado, revela a imperiosidade da aplicação do postulado da proporcionalidade para a resolução dos conflitos entre eles ou em face de outros bens constitucionalmente protegidos. Isso é 
corolário da adoção da idéia de conteúdo essencial relativo dos direitos fundamentais, por meio da qual se reconhece sua natureza principiológica. E um dos requisitos ínsitos à proporcionalidade é a judicialidade, isto é, somente o Poder Judiciário poderá avaliar o caso concreto e efetuar o sopesamento dos valores envolvidos.

Por fim, o enunciado do devido processo legal exige que as restrições à liberdade só podem ser perpetradas no bojo de um processo que, por sua vez, é o meio pelo qual o magistrado exerce sua função jurisdicional, sendo um mecanismo que proporciona a observância de diversas garantias. Entendendo a liberdade como quaisquer direitos individuais, as limitações a eles só poderão ser efetuadas por membros do Poder Judiciário.

De todo o exposto, depreende-se que os casos de reserva de jurisdição implícita serão eleitos sempre que se constatar uma situação que ensejar a limitação de um direito fundamental ou outro bem constitucionalmente protegido, em decorrência de um conflito de interesses que só pode ser solucionado de forma definitiva pelo Poder Judiciário.

Estabelecida essa premissa, a continuidade da tarefa proposta depende da definição do exato alcance dos poderes investigatórios atribuídos às Comissões Parlamentares de Inquérito. Essa empreeitada, contudo, só pode ser realizada com o entendimento de alguns outros pressupostos.

O Processo Penal é o palco do constante conflito entre liberdade e segurança. Dada a enorme relevância dos interesses envolvidos, a intervenção judicial é indispensável para sua solução, até para que se atinja o resultado justo preconizado pela noção de eficiência. Para o melhor desempenho desse papel, o magistrado deve se fundar na atividade cognitiva, buscando o melhor conhecimento dos fatos para que possa aplicar o direito da melhor maneira possível. Todavia, deve-se atentar para o limite que os direitos individuais representam à reconstrução fática, o que enseja a consolidação do conceito de verdade processualmente possível.

A instrução criminal é a fase na qual são colhidos os elementos que servirão ao embasamento da decisão judicial. Os instrumentos de coleta desses dados que, ao final, resultarão da produção da prova, muitas vezes ensejam restrições a direitos fundamentais. Haverá, portanto, um conflito entre o interesse de punir e os direitos do indivíduo, o que 
exigirá a intervenção do Poder Judiciário. Daí porque os meios de prova e principalmente os meios de obtenção de prova que apresentarem riscos aos direitos fundamentais deve ser submetidos à reserva de jurisdição.

Alguns deles são submetidos à cláusula de reserva de jurisdição por expressa previsão constitucional, como a interceptação telefônica e a busca e apreensão. Outros têm a necessidade de prévia ordem judicial definida em lei ordinária, como a condução coercitiva de testemunha. Por derradeiro, há aqueles que se submetem à reserva de jurisdição implícita, como a quebra de sigilo de dados e financeiro, pois dependem do entendimento de sua essência para exigir a autorização de um magistrado para sua realização.

Esses meios de prova e de obtenção de prova são bastante utilizados pelas Comissões Parlamentares de Inquérito no desenvolvimento de seus trabalhos de fiscalização do Poder Executivo. Conquanto não tenham por escopo promover a punição de indivíduos, mas sim de apurar fatos ocorridos no âmbito da administração pública, possuem o caráter investigativo e, às vezes, podem ser entendidas como forma de investigação preliminar, uma vez que o material colhido em um inquérito parlamentar pode dar ensejo à proposição de uma ação penal.

Com o intuito de aparelhar as CPIs e possibilitar uma boa execução de suas atribuições, o constituinte conferiu a elas, no $\S^{\circ}$ do artigo 58 da $\mathrm{CF}$, poderes investigatórios próprios de autoridades judiciais. A partir de então, a confusão foi instalada. É possível identificar as mais variadas interpretações sobre esse preceito, sendo que, freqüentemente, os membros das comissões entendem possível a determinação de medidas restritivas de direitos fundamentais, tais como a quebra do sigilo financeiro. Não raro, essa posição é ratificada pelos tribunais superiores.

No entanto, para compreender o exato alcance do dispositivo constitucional e conseguir compatibilizar a atuação no âmbito do inquérito parlamentar com a tese sobre a reserva de jurisdição, é necessário entender a diferença entre atos de investigação, atos de instrução e atos de prova. Além disso, há que se ter em mente que o artigo $58, \S 3^{\circ}$ da $\mathrm{CF}$ foi fruto de uma transposição de preceito semelhante na Constituição portuguesa, cujo sistema processual é diverso do brasileiro. 
O inquérito parlamentar tem a natureza de procedimento político-administrativo, podendo ser comparado ao inquérito policial. Neste, são executados atos de investigação, com o escopo de buscar elementos acerca de um fato aparentemente ilícito, e atos de instrução, os quais representam a materialização dos primeiros e buscam comprovar a veracidade de um enunciado, tomando por base uma hipótese de acusação já elaborada. Entretanto, não há que se falar em produção de prova neste momento, uma vez que esta depende da efetivação do contraditório na presença do juiz natural. Tampouco podem ser praticados atos pertencentes ao núcleo da função jurisdicional, notadamente, a intervenção em direitos fundamentais, ainda que relacionada a medidas investigativas.

As mesmas conclusões devem ser aplicadas ao inquérito parlamentar, porque, assim como o policial, não é conduzido por um membro do Poder Judiciário, órgão adequado à consecução da função exclusivamente jurisdicional. Com efeito, os parlamentares não possuem imparcialidade, nem isenção, estando sempre comprometidos com um propósito político, haja vista a finitude de seu mandato e a preocupação com o eleitorado. Ainda, não possuem formação jurídica, indispensável para a análise técnica das questões e para a legitimação das decisões com base no conhecimento dos fatos.

Por outro lado, o sistema acusatório adotado pela Constituição Federal e pelo Código de Processo Penal brasileiro não permite a realização de investigações pelo juiz. Ao magistrado incumbe julgar, apreciar as provas produzidas pelas partes e exercer o papel de guardião de direitos.

Já no sistema português, existe a figura do juiz de instrução, o qual atua em uma fase preliminar e tem maior liberdade para efetuar alguns atos de investigação e instrução. Nesse contexto, ao se conferir poderes investigatórios às CPIs, o constituinte português inspirou-se nessa figura. Utilizou o termo "investigatórios" de maneira ampla e imprópria, pretendendo abarcar os atos investigatórios e os instrutórios, excluindo as atividades exclusivamente judiciais, atinentes ao núcleo da função jurisdicional.

De todo o exposto, defendemos a corrente ampla da reserva de jurisdição aplicada às CPIs, que a reconhece quando é extraída de forma implícita dos princípios norteadores do sistema jurídico. Consequiência disso é que além de não poder determinar interceptações telefônicas, busca domiciliar, condução coercitiva de testemunha e prisão, as Comissões 
Parlamentares de Inquérito também não podem efetuar a quebra de sigilo financeiro ou de outros dados.

Portanto, o artigo $58, \S 3^{\circ}$ deve ser interpretado de maneira a permitir, no âmbito do inquérito parlamentar, a realização de diligências que seus membros entenderem necessárias, como a convocação de Ministros de Estado, a tomada de depoimento de quaisquer autoridades federais, estaduais ou municipais, a oitiva de indiciados, a inquirição de testemunhas e a requisição de informações e documentos perante repartições públicas e autárquicas. No caso de entenderem necessária a realização de uma medida restritiva de direito fundamental no desenrolar de seus trabalhos de investigação, devem requerer à autoridade judiciária competente de forma motivada.

Esses são os reflexos da reserva de jurisdição no inquérito parlamentar. Tomando por base a tese de que é indispensável o reconhecimento da reserva de jurisdição implícita, as Comissões Parlamentares de Inquérito não estão autorizadas a efetivar qualquer meio de prova ou de obtenção de prova que implique restrição a direito fundamental sem prévia autorização judicial. Essa idéia é corroborada pelo Projeto de Lei do Senado Federal n. ${ }^{\circ}$ 156/2009, que, se aprovado, positivará em seu art. 15, XII, $d$, a cláusula de reserva de jurisdição para todos os meios de obtenção de prova que restringirem direitos fundamentais.

Destaque-se que a inobservância da cláusula de reserva de jurisdição implica, em última instância, atentado ao Estado Democrático de Direito, uma vez que o exercício de função exclusivamente jurisdicional por órgão diverso do Poder Judiciário implica violação ao princípio da separação dos poderes, cláusula pétrea da Constituição Federal brasileira. 


\section{BIBLIOGRAFIA}

Afonso, Orlando Viegas Martins, Poder Judicial - Independência in dependência, Coimbra, Livraria Almedina, 2004.

ALEXY, Robert, Teoria dos Direitos Fundamentais, Virgílio Afonso da Silva (trad.), São Paulo, Malheiros Editores, 2008.

Antonio, Ángel Luis Alonso de e Antonio, José Antonio Alonso de, Derecho Constitucional Español, $4^{\mathrm{a}}$ Ed. Madrid, Editorial Universitas S.A., 2006.

Aulete, Caldas, Dicionário contemporâneo da língua portuguesa - Vol. III, $4^{\mathrm{a}}$ ed., Rio de Janeiro, Delta, 1958.

ÁvilA, Humberto, Teoria dos princípios: da definição à aplicação dos princípios jurídicos, 4a ed., São Paulo, Malheiros Editores, 2005.

Avolio, Luiz Francisco Torquato, Provas Ilícitas: interceptações telefônicas, ambientais e gravações clandestinas, $3^{\mathrm{a}}$ ed. rev., ampl. e atual. em face das leis 9.296/96 e 10.217/2001 e da jurisprudência, São Paulo, Editora Revista dos Tribunais, 2003.

BADARÓ, Gustavo Henrique Righi Ivahy, Limites aos poderes investigatórios das comissões parlamentares de inquérito, in Boletim IBCCRIM, São Paulo, v. 7, nº 83 (esp.), out. 1999, p. 11-12.

BANDEIRA, Gustavo A interceptação do fluxo de comunicações por sistemas de informática e sua constitucionalidade, in Revista de Direito do Tribunal de Justiça do Estado do Rio de Janeiro, n. ${ }^{\circ}$ 55, abril/junho de 2003, p. 32-42.

BARACHO, José Alfredo de Oliveira, As Comissões Parlamentares na Constituição de

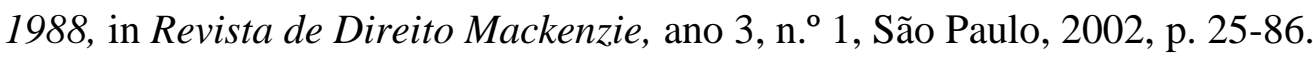


BARros, Marco Antonio de, A busca da verdade no processo penal, São Paulo, Editora Revista dos Tribunais, 2002.

BARros, Suzana de Toledo, $O$ princípio da proporcionalidade e o controle de constitucionalidade das leis restritivas de direitos fundamentais, $3^{\text {a }}$ ed., Brasília, Brasília Jurídica, 2003.

BArroso, Luis Roberto, Comissões Parlamentares de Inquérito - Limite de sua competência - sentido da expressão constitucional "poderes de investigação próprios das autoridades judiciais" - inadmissibilidade de busca e apreensão sem mandado judicial, in Boletim de Direito Administrativo, ano XII, n. ${ }^{12}$, dez. 1996, p. 799-813.

Barroso, Luís Roberto, Comissões Parlamentares de Inquérito e suas Competências: Política, Direito e Devido Processo Legal, in Revista de Direito da Associação dos Procuradores do Novo Estado do Rio de Janeiro, 2000, p. 61-86.

Bastos, Celso Ribeiro, Curso de Teoria do Estado e Ciência Política, $4^{\mathrm{a}}$ Ed., São Paulo, Editora Saraiva, 1999.

Belloque, Juliana Garcia, Sigilo bancário: análise crítica da LC 105/2001, São Paulo, Editora Revista dos Tribunais, 2003.

BobBio, Noberto, O futuro da democracia, Marco Aurélio Nogueira (trad.), $10^{\mathrm{a}}$ ed., São Paulo, Paz e Terra, 2000.

BocCARdo, Mauro Augusto, A decidibilidade da verdade processual à luz do garantismo, in Revista Jurídica da Universidade de Franca, ano 9, n. ${ }^{\circ}$ 17, $2^{\circ}$ semestre, Franca, Editora Unifran, 2007, 103-116.

Brun, Inaki Riano, La instrucción Criminal em el Proceso Penal, Navarra, Thomson Aranzadi, 2008.

Caetano, Marcello, Manual de Direito Administrativo, $10^{\mathrm{a}}$ ed., $2^{\mathrm{a}}$ reimp., Tomo I, Coimbra, Livraria Almedina, 1982. 
CAnotilho, José Joaquim Gomes, Direito constitucional e teoria da constituição, $7^{\mathrm{a}}$ ed., Coimbra, Livraria Almedina, 2003.

Carajelescov, Yuri, Comissões Parlamentares de Inquérito à luz das disciplinas constitucional, legal e jurisprudencial luso-portuguesa e brasileira, Curitiba, Juruá Editora, 2007.

CASSEB, Paulo Adib, Controle governamental exercido pelo legislativo, in Repertório de Jurisprudência IOB, Vol. I, n. ${ }^{\circ}$ 01/2003, p. 30-23.

Chiappini, Carolina e Peixoto, Marcelo Magalhães, Sigilo bancário e fiscal no direito brasileiro, in PIZOLIO, Reinaldo e GAVALDÃo JR., Jayr Viégas (coord.), Sigilo fiscal e bancário, São Paulo, Quartier Latin, 2005, p. 395-425.

Cintra, Antonio Carlos de Araújo, Grinover, Ada Pellegrini e Dinamarco, Cândido Rangel, Teoria Geral do Processo, 17ª ed., São Paulo, Malheiros Editores, 2001.

CLÈVE, Clèmerson Merlin e SEHN, Solon, Crimes fiscais e sigilo bancário: pressupostos e limites constitucionais, in Heloisa Estellita Salomão (coord.), Direito Penal Empresarial, São Paulo, Dialética, 2001, p. 57-74.

CoElHo, Inocêncio Mártires, O Perfil Constitucional do Estado Contemporâneo: o Estado Democrático de Direito, in Revista de Informação Legislativa, ano 30, n. ${ }^{\circ} 118$, abrilljunho 1993, Brasília, p. 5-18.

Comparato, Fabio Konder, Comissões Parlamentares de Inquérito - Limites, in Revista Trimestral de Direito Público, n. ${ }^{\circ}$ 5, Malheiros Editores, 1994, p. 66-74. , Para Viver a Democracia, São Paulo, Brasiliense, 1989.

CORTEZ, Luís Francisco Aguilar Cortez, Judiciário e Democracia: organização e funcionamento do Judiciário na Constituição Federal de 1988, Tese de Doutorado apresentada à Faculdade de Direito da Universidade de São Paulo, 2004. 
Costa, Helena Regina Lobo da, A Dignidade Humana: teorias de prevenção geral positiva, São Paulo, Editora Revista dos Tribunais, 2008.

Cretella Junior, José, Comissão Parlamentar de Inquérito (CPI), in Revista Forense, Vol. 353, Jan-fev 2001, Rio de Janeiro, p. 447-454.

CRUZ, Rogério Schietti Machado, A verdade processual em Ferrajoli, in Boletim IBCCRIM, São Paulo, v. 9, n. ${ }^{\circ}$ 106, set. 2001, p. 9-10.

Dallari, Dalmo de Abreu, Elementos de Teoria Geral do Estado, 22 ${ }^{\mathrm{a}}$ Ed., São Paulo, Editora Saraiva, 2001.

, Estado de Direito e Cidadania, in Direito Constitucional -

Estudos em Homenagem a Paulo Bonavides, Eros Roberto Grau e Willis Santiago Guerra Filho (org.), São Paulo, Malheiros Editores, 2001, p. 194-200.

O Poder dos Juízes, $3^{\mathrm{a}}$ Ed. rev, São Paulo, Editora Saraiva, 2007.

De Plácido e Silva, Vocabulário jurídico - vol. III, 6a. ed., Rio de Janeiro, Editora Forense, 1980.

DERVIEUX, Valérie, O sistema francês, in Processo penal e direitos do homem: rumo à consciência européia, Delmas-MARTY, Mireille (org.), Fernando de Freitas Franco (trad.), Barueri, Manole, 2004, p. 151-242.

Deu, Teresa Armenta Leciones de Derecho Procesal Penal, $3^{\mathrm{a}}$ Ed., Madrid, Marcial Pons, 2007.

DIAS, Jorge Figueiredo, Os princípios estruturantes do processo e a revisão de 1998 do CPP, in Revista Portuguesa de Ciência Criminal, ano 8 Fasc. 2, Abril-jun 1998, p. 199213.

Dimoulis, Dimitri e Martins, Leonardo, Teoria Geral dos Direitos Fundamentais, São Paulo, Editora Revista dos Tribunais, 2006. 
Dinamarco, Cândido Rangel, A instrumentalidade do processo, $11^{\mathrm{a}}$ ed., São Paulo, Malheiros Editores, 2003.

, Candido Rangel, Instituições de Direito Processual Civil, V. I, $1^{\mathrm{a}}$ Ed., São Paulo, Malheiros Editores, 2002.

DinIZ NeTO, Eduardo, Meios de obtenção de prova criminal: considerações de direito constitucional aplicado, in Revista da Associação Brasileira de Professores de Ciências Penais, ano 4, n. ${ }^{\circ}$ 6, jan-jun/2007, p. 151-173.

DINIZ, Maria Helena, Dicionário jurídico, V. 1, São Paulo, Editora Saraiva, 1998.

DUClERC, Elmir, Prova Penal e Garantismo: uma investigação crítica sobre a verdade fática construída através do processo, Rio de Janeiro, Editora Lumen Juris, 2004.

DuTRA, Delamar José Volpato, A legalidade como forma do Estado de Direito, in Kriterion, n. ${ }^{\text {}}$ 109, Belo Horizonte, Jun/2004, p. 57-80, disponível em: http://www.scielo.br/scielo.php?pid=S0100-2X2004000100004\&script=sci_arttext. Acesso em 17.11.2008.

FARIA, Cássio Juvenal e Gomes, Luiz Flávio, Poderes e limites das CPIs, in Boletim IBCCRIM, São Paulo, v. 7, n. ${ }^{\circ}$ 79, jun. 1999, p. 12.

FARIAS, Edilson Pereira, Colisão de Direitos: a honra, a intimidade, a vida privada e a imagem versus a liberdade de expressão e informação, $2^{\mathrm{a}}$ ed. atual., Porto Alegre, Sergio Antonio Fabris Editor, 2000.

FERNANDES, Antonio Scarance, A Lei de Interceptação telefônica, in PENTEADO, Jaques de Camargo (coord.), Justiça Penal: críticas e sugestões: provas ilícitas e reforma pontual, São Paulo, Editora Revista dos Tribunais, 1997, p. 48-70.

, O equilíbrio na repressão ao crime organizado, in Crime organizado - aspectos processuais, in FERNANDES Antonio Scarance, ALMEIDA, José Raul Gavião de e Moraes, Maurício Zanoide de (coord.), Crime Organizado, São Paulo, Editora Revista dos Tribunais, 2009, p. 9-28. 
Processo Penal Constitucional, $5^{\text {a }}$ Ed. rev., atual e ampl., São Paulo, Editora Revista dos Tribunais, 2007.

Reflexões sobre as noções de eficiência e de garantismo no processo penal, in FERnANDES Antonio Scarance, AlmeIdA, José Raul Gavião de e MorAes, Maurício Zanoide de (coord.), Sigilo no processo penal: eficiência e garantismo, São Paulo, Editora Revista dos Tribunais, 2008, p. 9-28.

, O sigilo financeiro e a prova criminal, in CosTA, José Faria da, e SiLva, Marco Antonio Marques da (coord.), Direito Penal Especial, Processo Penal e Direitos Fundamentais - visão luso-brasileira, São Paulo, Editora Quartier Latin, 2006, p. $455-484$.

Ferrajoli, Luigi, Direito e Razão, Ana Paula Zomer Sica, Fauzi Hassan Choukr, Juarez Tavares, Luiz Flávio Gomes (trad.). 2a . ed., São Paulo, Editora Revista dos Tribunais, 2006. , Jurisdição e democracia, Eduardo Maia Costa (trad.), in Revista do Ministério Público, ano 18, out.-dez. 1997, n. ${ }^{\circ}$ 72, p. 11-29.

Ferraz Junior, Tercio Sampaio, Sigilo de dados: o direito à privacidade e os limites à função fiscalizadora do Estado, in Cadernos de Direito Constitucional e Ciência Política, ano 1, out/dez de 1992, p. 77-90.

, Introdução ao Estudo do Direito - Técnica, Decisão,

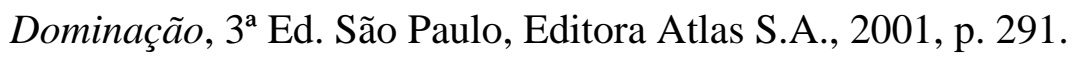

FERREIRA, Jorge, Regime Jurídico dos Inquéritos Parlamentares (Anotado), Coimbra, Livraria Almedina, 1999.

Franco, Alberto Silva e STOCO, Rui (coord.), Código de processo penal e sua interceptação jurisprudencial, vol. I, $2^{\text {a }}$ ed. rev. atual. e ampl., São Paulo, Editora Revista dos Tribunais, 2004. 
GARCIA, Edinês Maria Sormani, O fundamento da consagração da pessoa humana no texto constitucional brasileiro de 1988, in SEGALLA, José Roberto Martins e ARAUJO, Luiz Alberto David (coord.), 15 anos da Constituição Federal: em busca da efetividade, Bauru, EDITE, 2003, p. 211-229.

GoMES FiLHo, Antonio Magalhães, Direito à prova no processo penal, São Paulo, Editora Revista dos Tribunais, 1997.

, Notas sobre a terminologia da prova (reflexos no processo penal brasileiro), in YARSHEL, Flávio Luiz e MORAES, Mauricio Zanoide de(org), Estudos em homenagem à Professora Ada Pellegrini Grinover, São Paulo, DPJ Editora, 2005, p. 303-318.

GoMes, Luis Flávio e CervinI, Raúl, Interceptação telefônica: lei 9.296, de 24.07.96, São Paulo, Editora Revista Tribunais, 1997.

GOMES, Luis Flávio, Crimes fiscais e sigilo bancário: pressupostos e limites constitucionais, in SAlomão, Heloisa Estellita (coord.), Direito Penal Empresarial, São Paulo, Dialética, 2001, p. 151-158.

GonçAlves, João Batista $O$ devido processo legal e o pacto de São José da Costa Rica, Tese de doutorado apresentada à Faculdade de Direito da Universidade de São Paulo, 1999.

Gonçalves, Luiz Carlos dos Santos Gonçalves, Poderes de Investigação das Comissões Parlamentares de Inquérito, São Paulo, Editora Juarez de Oliveira, 2001.

GRAMSTRUP, Erik Frederico, Sigilo Fiscal e Bancário: fundamentos normativos $e$ principiológicos da quebra, in PIZOLIO, Reinaldo e GAVALDÃo JR., Jayr Viégas (coord.), Sigilo fiscal e bancário, São Paulo, Quartier Latin, 2005, p. 227-245.

GRAU, Eros Roberto, $O$ direito posto e o direito pressuposto, $5^{\mathrm{a}}$ Ed. rev. e ampl., São Paulo, Editora Malheiros, 2003. 
Grinover, Ada Pellegrini, A Marcha do Processo, Rio de Janeiro, Forense Universitária, 2000.

, Iniciativa instrutória do juiz no processo penal acusatório, in Revista Forense, n. ${ }^{\circ} 347$, jul-set de 1999, p. 3-10.

Liberdades públicas e processo penal: as interceptações telefônicas, $2^{a}$ ed. atual., São Paulo, Editora Revista dos Tribunais, 1982.

GrinOver, Ada Pellegrini, FernAndes, Antonio Scarance, GoMES FILHO, Antonio Magalhães, As nulidades no processo penal, $10^{\mathrm{a}}$ ed. rev e atual, São Paulo, Editora Revista dos Tribunais, 2007.

GuinAlz, Ricardo Donizete, Princípio da proporcionalidade e o processo penal, Dissertação de Mestrado apresentada à Faculdade de Direito da Universidade de São Paulo, 2002.

Hassemer, Winfried, Fundamentos del Derecho Penal, Francisco Muñoz Conde e Luis Arroyo Zapatero (trad.), Barcelona, José María Bosch, 1984.

Kelsen, Hans, Teoria Pura do Direito, trad. João Baptista Machado, 6a Ed., São Paulo, Martins Fontes, 1998.

KorZENIAK, Jose, La separacion de los poderes del gobierno, in Defensa de La Constitucion Nacional, Facultad de Derecho y Ciencias Sociales, Montevideo, 1986, p. 2535 .

LACAVA, Thaís Aroca Datcho, Sigilo na CPI e as garantias individuais, in FERNANDES, Antonio Scarance, AlmeidA, José Raul Gavião de, e MoraEs, Maurício Zanoide de, Sigilo no processo penal: eficiência e garantismo, São Paulo, Editora Revista dos Tribunais, 2008, p. 115-137.

LOPES JR., Aury, Sistemas de Investigação Preliminar no Processo Penal, $4^{\mathrm{a}}$ Ed. rev, ampl.e atual., Rio de Janeiro, Editora Lumen Juris, 2006. 
Lowenstein, Karl, Teoría de La Constitución, Alfredo Gallego Anabitarte (trad.), Barcelona, Ediciones Ariel, 1970.

Machado, André Augusto Mendes e KeHDI, Andre Pires de Andrade, Sigilo das comunicações e de dados, in Fernandes, Antonio Scarance, AlmeIdA, José Raul Gavião de, e Moraes, Maurício Zanoide de, Sigilo no processo penal: eficiência e garantismo, São Paulo, Editora Revista dos Tribunais, 2008, p. 239-266.

MACHADO, Santiago Muñoz, La reserva de jurisdicción, Madrid, La Ley, 1989.

MARCÃo, Renato e TANAMATI, Rodrigo A. F., Condução coercitiva determinada por Comissão Parlamentar de Inquérito, in ICP, ago/2006, p. 7-8.

MARTOS, José Antonio de Faria, A natureza processual das provas produzidas através das interceptações telefônicas, in Revista Jurídica da Universidade de Franca, ano 8, n. ${ }^{\circ} 14,1^{\circ}$ sem., Franca, 2005, p. 136-141.

Mathieu, Bertrand, Verpeaux, Michel, Droit constitutionnel, Paris, Press Universitaires de France, 2004.

Mello, Celso Antonio Bandeira de, Curso de Direito Administrativo, 25ª ed., rev. e atual. até a EC 56 de 10.12.2007, São Paulo, Malheiros Editores, 2008.

Mercone, Mario Diritto Processuale Penale, XVI Edizione, Esselibri-Simone, Napoli, 2008.

Miranda, Jorge, Sobre as Comissões Parlamentares de Inquérito em Portugal, in Revista de Direito Constitucional e Internacional, n. ${ }^{\circ}$ 33, ano 8, out-dez de 2000, São Paulo, Editora Revista dos Tribunais, p. 61-67.

, Teoria do Estado e da Constituição, Coimbra, Coimbra Editora, 2002.

Moraes, Alexandre de, A constitucionalidade do Parágrafo único do art. $1^{o}$ da Lei 9.296/96 (Interceptações do Fluxo de Comunicações em Sistemas de Informática e Telemática), in Boletim IBCCrim, n. ${ }^{\circ}$ 54, maio/1997, p. 5. 
Moraes, Maurício Zanoide de, Interceptação Telefônica (L. 9.296/96), in Franco, Alberto Silva e STOco, Rui (coord.), Leis Penais e sua Interpretação Jurisprudencial, 7 ed. rev., atual. e ampl., São Paulo, Editora Revista dos Tribunais, 2001, p. 1761-1824. , Presunção de inocência no Processo Penal Brasileiro: análise de sua estrutura normativa para a elaboração legislativa e para a decisão judicial, Tese apresentada à Egrégia Congregação da Faculdade de Direito da Universidade de São Paulo como exigência parcial à obtenção do título de Livre-Docência em Direito Processual Penal, São Paulo, 2008.

Sigilo Financeiro (LC 105/2001 e Dec. 3.724/200), in Franco, Alberto Silva e StOco, Rui (coord.), Leis Penais e sua Interpretação Jurisprudencial, 7 ed. rev., atual. e ampl., São Paulo, Editora Revista dos Tribunais, 2001, p. 2967-3096.

MourA, Maria Thereza Rocha de Assis, Breve notícia sobre o projeto de lei do senado federal 156/2009, que trata da reforma do código de processo penal, in Boletim IBCCrim, ano 17, n. ${ }^{\circ}$ 200, São Paulo, julho de 2009, p. 4

Meios de impugnação à quebra indevida de sigilo bancário, SAlOMÃo, Heloisa Estellita (coord.), in Direito Penal Empresarial, São Paulo, Dialética, 2001, p. 161-182.

OliveirA, Ary Brandão de, Considerações acerca do segredo bancário, in Revista de Direito Civil, Imobiliário, Agrário e Empresarial, n. ${ }^{\circ}$ 23, ano 7, jan-mar, 1983, p. 114-124.

OliveIra, Eugêncio Pacelli de, Curso de Processo Penal, 11ª Ed., Rio de Janeiro, Editora Lumen Juris, 2009.

PACHECO, Denilson Feitoza, Direito processual penal: teoria, crítica e práxis, $5^{\mathrm{a}}$ Ed. rev. e atual. com Emenda Constitucional da Reforma do Judiciário, Niterói, Impetus, 2008.

, O princípio da proporcionalidade no direito processual penal brasileiro, Rio de Janeiro, Editora Lumen Juris, 2007, 
PImenta, Paulo Roberto Lyrio, Possibilidade de Quebra do Sigilo Bancário pelo Fisco à Luz da Constituição Federal, in PIZOLIO, Reinaldo e GaVAldẽo JR., Jayr Viégas (coord.), Sigilo fiscal e bancário, São Paulo, Quartier Latin, 2005, p. 93-108.

Piovesan, Flavia, Direitos Humanos e o direito constitucional internacional, $7^{\mathrm{a}}$ ed. rev., ampl. e atual., São Paulo, Editora Saraiva, 2006.

Pitombo, Cleunice A. Valentim Bastos, Comissão Parlamentar de Inquérito e os institutos da busca e apreensão, in Penteado, Jaques de Camargo, Justiça Penal-7, São Paulo, Editora Revista dos Tribunais, 2000, p. 267-297.

, Da Busca e da Apreensão no Processo Penal, $2^{\mathrm{a}}$ ed. rev. atual. e ampl., São Paulo, Editora Revista dos Tribunais, 2005.

Processo penal: prova e verdade, Tese de doutorado apresentada na Faculdade de Direito da Universidade de São Paulo, São Paulo, 2003.

Pitombo, Sergio Marcos de Moraes, Breves notas sobre o anteprojeto de lei, que objetiva modificar o Código de Processo Penal, no atinente à investigação policial, in SCHECAIRA, Sérgio Salomão (org.), Estudos Criminais em Homenagem a Ecandro Lins e Silva, São Paulo, Editora Método, 2001, p. 337-351.

Inquérito policial: exercício do direito de defesa, in

Boletim IBCCrim, n. ${ }^{\text {8 }}$ 83, esp., Out., 1999.

O juiz penal e a pesquisa da verdade material, in PorTo, Hermínio Alberto Marques e Silva, Marco Antonio Marques da (orgs), Processo Penal e Constituição Federal, São Paulo, Acadêmica, 1993, p. 72-77.

RANGEL, Paulo Castro, Reserva de Jurisdição, sentido dogmático e sentido jurisprudencial, Porto, Universidade Católica Editora, 1997.

ReAle, Miguel e Martins Ives Gandra da Silva, Sigilo bancário: inconstitucionalidade do Decreto n. 4.489 de 28/11/2002 por macular o processo legislativo plasmado na lei 
suprema e infringir direitos fundamentais do cidadão - opinião legal, in PIZOLIO, Reinaldo e Gavaldão JR., Jayr Viégas (coord.), Sigilo fiscal e bancário, São Paulo, Quartier Latin, 2005, p. 43-72.

Reale, Miguel, O Estado Democrático de Direito e o Conflito das Ideologias, $2^{\mathrm{a}}$ ed. rev., São Paulo, Editora Saraiva, 1999. , Questões de direito público, São Paulo, Editora Saraiva, 1997.

REIS, José Carlos Vasconcellos, Controle externo do Poder Judiciário e Separação de Poderes, in Quaresma, Regina e OliveIRA, Maria Lúcia de Paula (coord.), Direito Constitucional Brasileiro - perspectivas e controvérsias contemporâneas, Rio de Janeiro, Editora Forense, 2006, p. 193-217.

RIANI, Frederico Augusto D'Avila, Comissão Parlamentar de Inquérito: Requisitos para criação, objeto e poderes, in Revista do Instituto de Pesquisas e Estudos - Divisão Jurídica, Instituição Toledo de Ensino Bauru, Dez 1999 a Mar 2000, p. 335-365.

RIVERO, Jean, Les libertes publiques, $4^{\mathrm{a}}$ ed. Paris, Puf, 1989.

Russomano, Rosah, Curso de Direito Constitucional, $5^{\mathrm{a}}$ ed. rev. e atual., Rio de Janeiro, Freitas Bastos Editora, 1997.

SAAD, Marta, $O$ direito de defesa no inquérito policial, São Paulo, Editora Revista dos Tribunais, 2004.

Sales, Denis, O Papel do Juiz, in Delmas-Marty, Mireille (org.), Processo penal e direitos do homem: rumo à consciência européia, Fernando de Freitas Franco (trad.), Barueri, Manole, 2004, p. 507-557.

SARAIVA FILHO, Oswaldo Othon de Pontes, $O$ acesso direito aos dados bancários por parte do fisco: a transferência do sigilo bancário para o sigilo fiscal, in PIZOLIO, Reinaldo e GAVALDÃo JR., Jayr Viégas (coord.), Sigilo fiscal e bancário, São Paulo, Quartier Latin, 2005, p. 131-197. 
SCHIER, Paulo Ricardo, As Comissões Parlamentares de Inquérito e a Defesa dos Direitos Individuais, in Revista da Academia Brasileira de Direito Constitucional, V. 3, 2003, p. 277-278.

SERRANO, Nicolas Gonzáles-Cuellar, Proporcionalidad y derechos fundamentales em el proceso penal, Madri, Colex, 1990.

Silva, Danielle Souza de Andrade e, A atuação do juiz no processo penal acusatório Incongruências no sistema brasileiro em decorrência do modelo constitucional de 1988, Porto Alegre, Sergio Antonio Fabris Editor, 2005.

A investigação preliminar nos delitos de competência originária de tribunais, Tese de Doutorado apresentada na Faculdade de Direito da Universidade de São Paulo, 2009.

Silva, Ivan Luís Marques da, Reforma Processual Penal de 2008: Lei 11.719/2008, procedimentos penais: Lei 11.690/2008, provas: Lei 11.689/2008, júri: comentadas artigo por artigo, São Paulo, Editora Revista dos Tribunais, 2008.

Silva, José Afonso da, Curso de direito constitucional positivo, $22^{\mathrm{a}}$ ed. rev. e atual., São Paulo, Malheiros Editores, 2003.

O Estado Democrático de Direito, in Direito Constitucional Brasileiro - perspectivas e controvérsias contemporâneas, QUARESMA, Regina e OliveIRA, Maria Lúcia de Paula (coord.), Rio de Janeiro, Editora Forense, 2006, p. 7-25.

Silva, Virgílio Afonso da, Direitos Fundamentais: conteúdo essencial, restrições $e$ eficácia, São Paulo, Malheiros Editores, 2009.

SILVEIRA, Renato de Mello Jorge, Da verdade dada à verdade buscada, in Boletim IBCCRIM, São Paulo, v. 8, n. ${ }^{\circ} 101$, abril 2001, p. 12-14.

SiqueIRA JR., Paulo Hamilton, Comissão Parlamentar de Inquérito, Rio de Janeiro, Elsevier, 2007. 
SOUZA JUNIOR, Antonio Umberto de, Entre a primeira e a última palavras ensaio sobre a amplitude da reserva constitucional de jurisdição, in Revista da Faculdade de Ciências Jurídicas e Sociais do Centro Universitário de Brasília, n. ${ }^{o}$ 13, janeiro/junho 2006, p. 75118.

SouzA, Hamilton Dias de, Sigilo Bancário e o direito à liberdade, in Revista Tributária e de Finanças Públicas, n. ${ }^{\circ}$ 30, ano 8, jan-fev, 2000, p. 139-145.

StumM, Raquel Denize, Princípio da proporcionalidade no direito constitucional brasileiro, Porto Alegre, Livraria do Advogado, 1995.

Tavares, André Ramos, Princípio da Dignidade da Pessoa Humana, in Segalla, José Roberto Martins e ArAujo, Luiz Alberto David (coord.), 15 anos da Constituição Federal: em busca da efetividade, Bauru, EDITE, 2003, 11-37.

, Repartição de funções estatais: fundamento, estrutura $e$ finalidade, in Revista do Advogado, Ano XXIII, n. ${ }^{\circ}$ 73, novembro de 2003, p. 21-26.

TAVARES, Juarez, A violação ao sigilo bancário em face da proteção da vida privada, in Revista Brasileira de Ciências Criminais, ano 1, jan/mar, 1993, p. 105-111.

THUMS, Gilberto, O mito sobre a verdade e os sistemas processuais, in FAYET JR., Ney, Ensaios penais em homenagem ao Professor Alberto Rufino Rodrigues de Sousa, Porto Alegro, Ricardo Lenz, 2003, p. 319-339.

Tonini, Paolo, A prova no processo penal italiano, Alexandra Martins e Daniela Mróz (trad.), São Paulo, Editora Revista dos Tribunais, 2002.

TourinHo FILHO, Fernando da Costa, Manual de processo penal, $6^{\mathrm{a}}$ ed. rev., atual., e aum., São Paulo, Editora Saraiva, 2004.

TuCCI, Rogério Lauria, Comissão Parlamentar de Inquérito (Atuação - Competência Caráter Investigatório), in Revista Brasileira de Ciências Criminais, ano 2, n. ${ }^{\circ}$ 6, abriljunho - 1994, p. 171-185. 
Direitos e garantias individuais no processo penal brasileiro, São Paulo, Editora Saraiva, 1993.

Velloso, Carlos Mário, da S., As Comissões Parlamentares de Inquérito e o sigilo das comunicações telefônicas, in Revista Brasileira de Ciências Criminais, ano 6, n. ${ }^{\circ}$ 24, out.dez. 1998, p. 125-143.

Verdú, Pablo Lucas, A luta pelo Estado de Direito, Agassiz Almeida Filho (trad. e pref.), Rio de Janeiro, Editora Forense, 2007.

Wajngarten, Aron e Briani, Alberto, Aplicação do Princípio da Dignidade Humana, in Segalla, José Roberto Martins e Araujo, Luiz Alberto David (coord.), 15 anos da Constituição Federal: em busca da efetividade, in 15 anos da Constituição Federal: em busca da efetividade, Bauru, EDITE, 2003, p. 39-55.

WALD, Arnoldo, O sigilo bancário no projeto de lei complementar de reforma do sistema financeiro e na lei complementar $n .^{\circ} 70$, in Cadernos de Direito Tributário e Finanças Públicas, n. ${ }^{\circ}$ 1, ano 1, out-dez de 1992, p. 196-209.

ZILli, Marcos Alexandre Coelho, A iniciativa instrutória do juiz no processo penal, São Paulo, Editora Revista dos Tribunais, 2003.

\subsection{INTERNET}

Dicionário Houaiss Eletrônico. Disponível em http://houaiss.uol.com.br.

http://www.camara.gov.br

http://www.legix.pt/docs/CPP.pdf

$\underline{\text { http://www.senado.gov.br }}$ 
http://www.stf.gov.br 